\title{
RELATIONS OF SURFACE-WATER QUALITY TO STREAMFLOW IN THE HACKENSACK, PASSAIC, ELIZABETH, AND RAHWAY RIVER BASINS, NEW JERSEY, WATER YEARS 1976-93
}

Water-Resources Investigations Report 98-4049

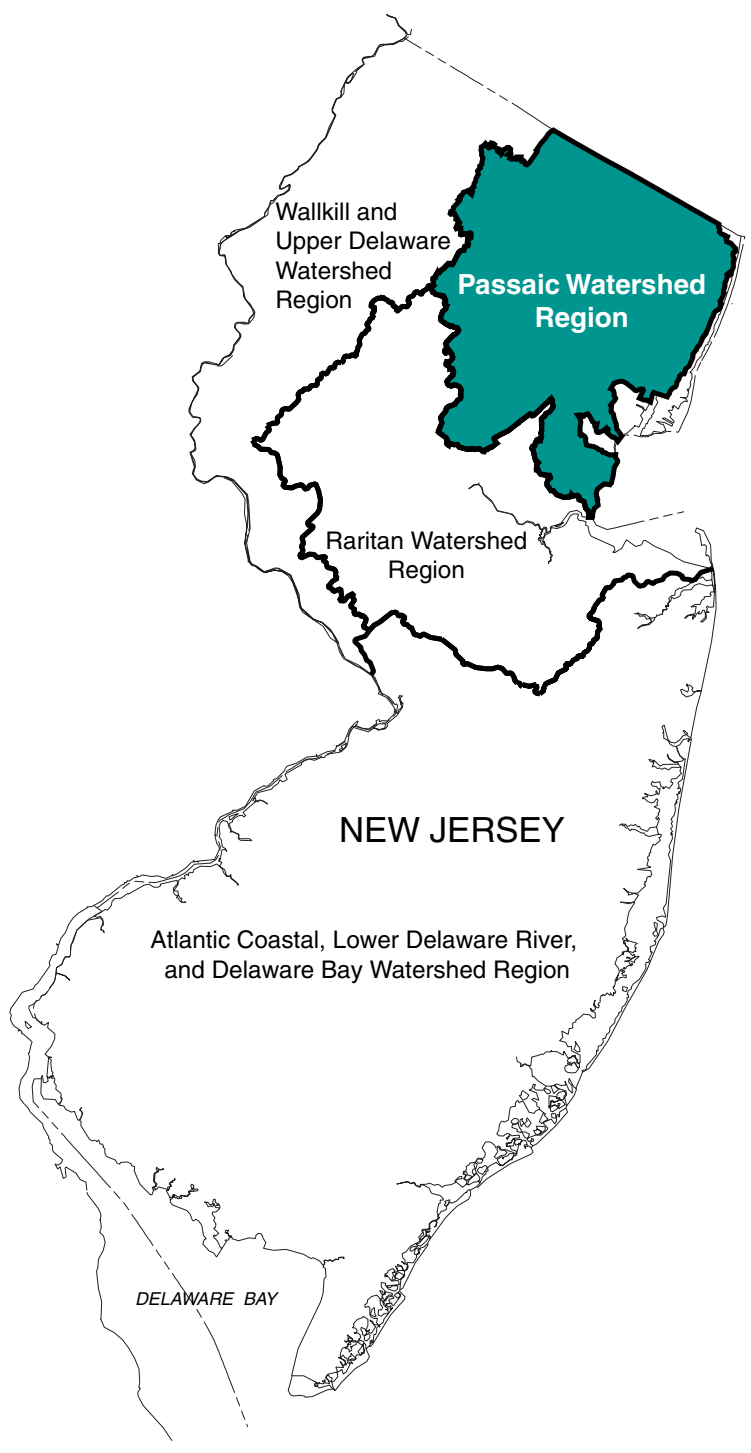

Prepared in cooperation with the NEW JERSEY DEPARTMENT OF ENVIRONMENTAL PROTECTION 


\section{RELATIONS OF SURFACE-WATER QUALITY TO STREAMFLOW IN THE HACKENSACK, PASSAIC, ELIZABETH, AND RAHWAY RIVER BASINS, NEW JERSEY, WATER YEARS 1976-93}

By Debra E. Buxton, Kathryn Hunchak-Kariouk, and R. Edward Hickman

U.S. Geological Survey

Water-Resources Investigations Report 98-4049

Prepared in cooperation with the NEW JERSEY DEPARTMENT OF ENVIRONMENTAL PROTECTION

West Trenton, New Jersey 1998 


\title{
U.S. DEPARTMENT OF THE INTERIOR
}

\author{
BRUCE BABBITT, secretary
}

\section{U.S. GEOLOGICAL SURVEY}

Thomas J. Casadevall, Acting Director

For additional information write to:

District Chief

U.S Geological Survey Mountain View Office Park

810 Bear Tavern Road, Suite 206

West Trenton, NJ 08628
Copies of this report can be purchased from:

U.S. Geological Survey

Branch of Information Services

Box 25286

Denver, CO 80225-0286 


\section{CONTENTS}

Page

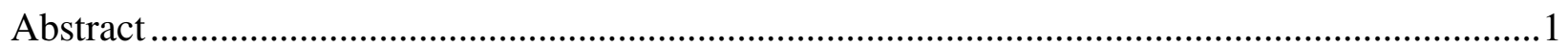

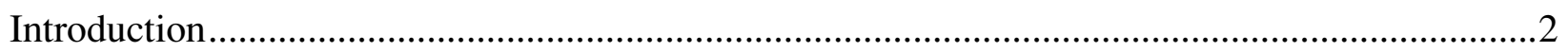

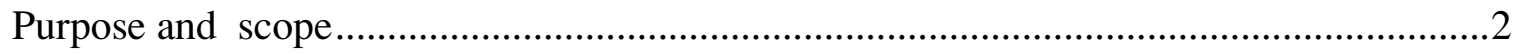

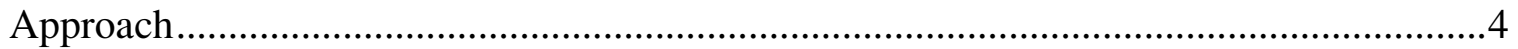

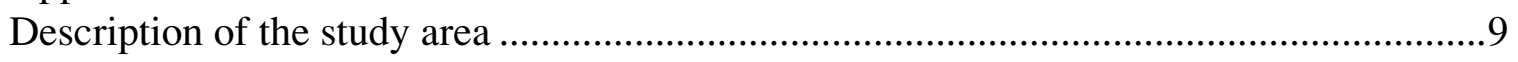

Hackensack River Basin ............................................................................ 9

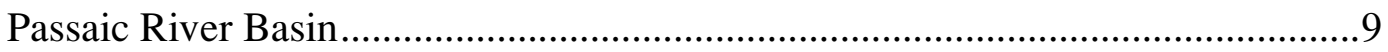

Elizabeth River Basin .............................................................................. 14

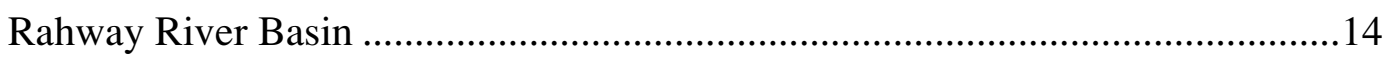

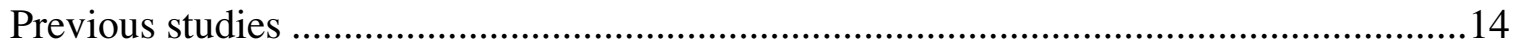

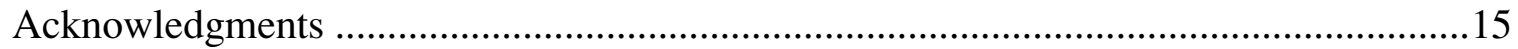

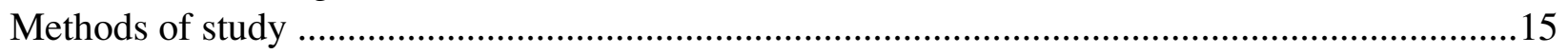

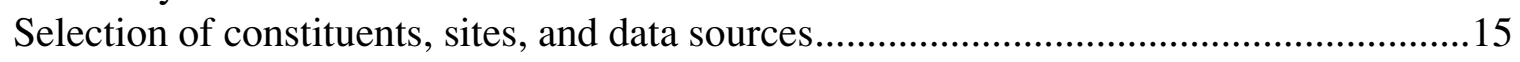

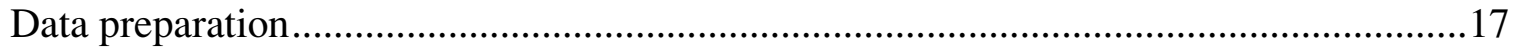

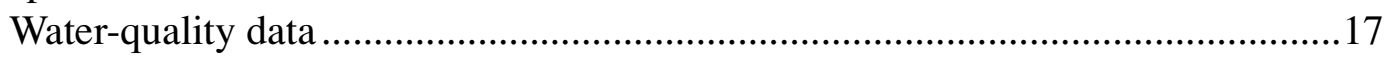

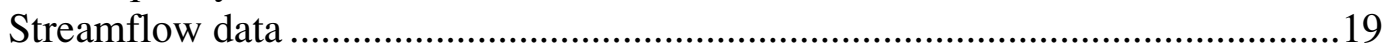

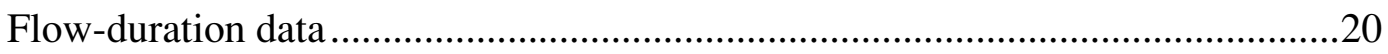

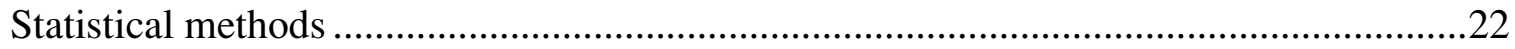

Calculation of medians .........................................................................22

Determination of relations of surface-water quality to streamflow ......................22

Relations of concentration to streamflow ...........................................23

Relations of load to streamflow ............................................................25

Trends in concentrations during low and high flows .............................22

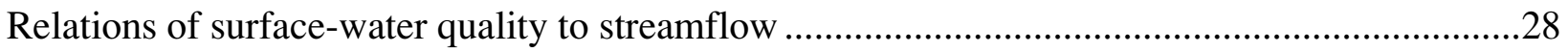

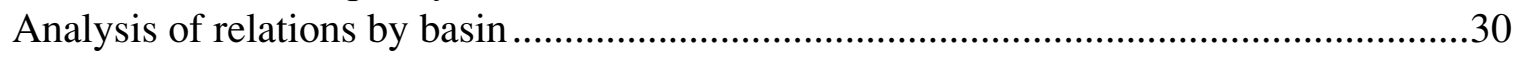

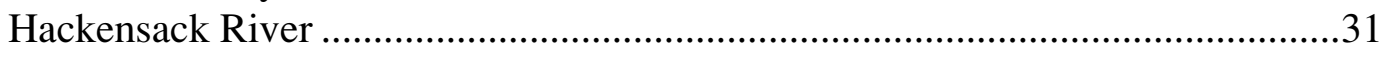

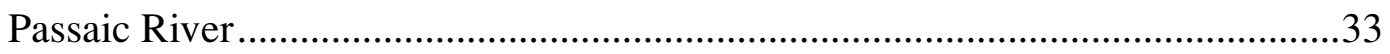

Upper Passaic River ......................................................................33

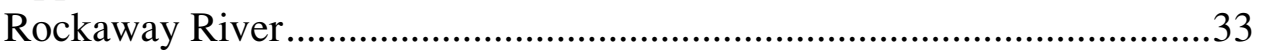

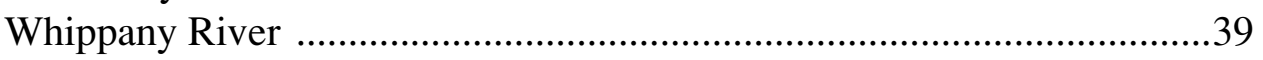

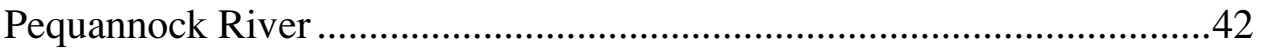

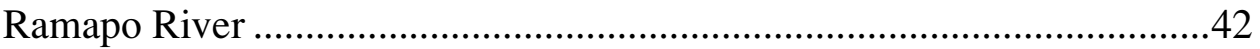

Pompton River .........................................................................4 42

Lower Passaic River ........................................................................4 47

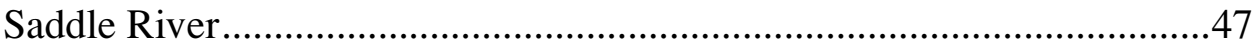

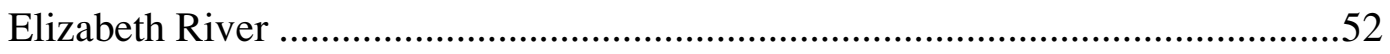

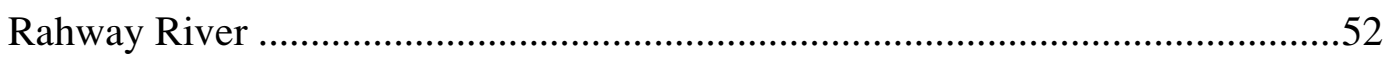

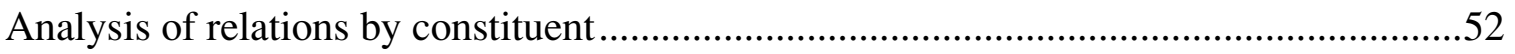

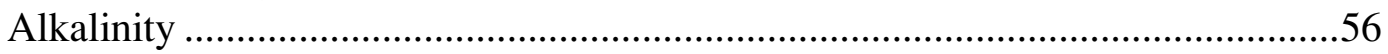

Relation of trends in concentration to flow conditions ............................57

Relation of load to streamflow...............................................................57

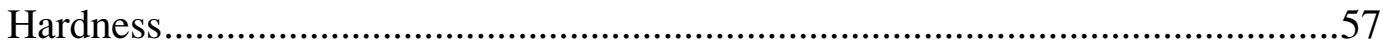




\section{CONTENTS--Continued}

Page

Relation of trends in concentration to flow conditions ..............................59

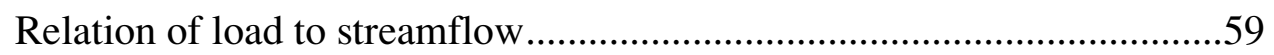

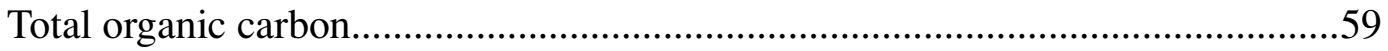

Relation of trends in concentration to flow conditions ................................61

Relation of load to streamflow.................................................................61

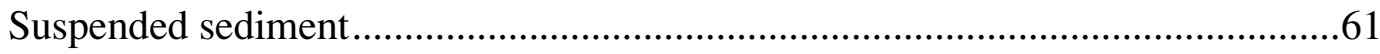

Relation of trends in concentration to flow conditions ...............................63

Relation of load to streamflow................................................................63

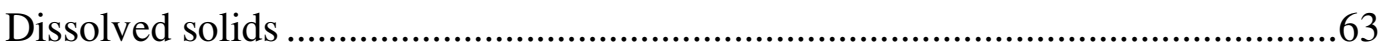

Relation of trends in concentration to flow conditions ................................65

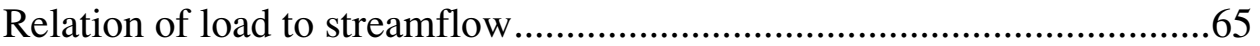

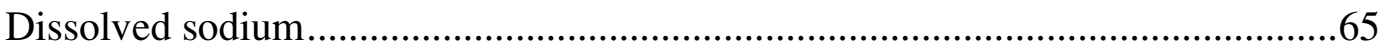

Relation of trends in concentration to flow conditions ................................65

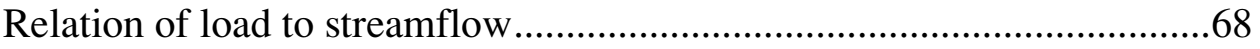

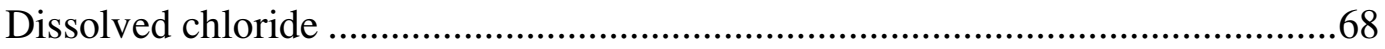

Relation of trends in concentration to flow conditions ..............................68

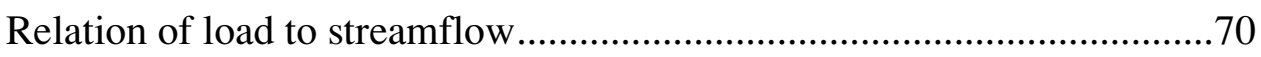

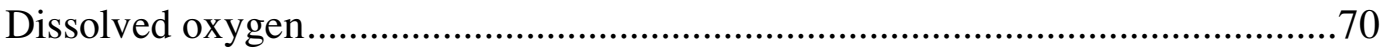

Relation of trends in concentration to flow conditions ...............................70

Relation of load to streamflow...............................................................

Fraction of dissolved oxygen at saturation ........................................................72

Relation of trends in concentration to flow conditions ...............................72

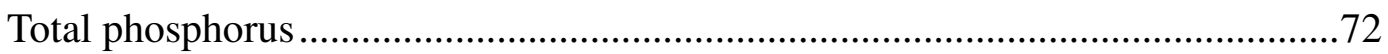

Relation of trends in concentration to flow conditions ...............................74

Relation of load to streamflow...............................................................74

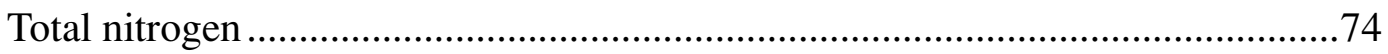

Relation of trends in concentration to flow conditions ................................76

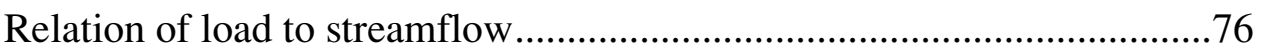

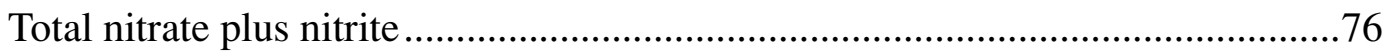

Relation of trends in concentration to flow conditions ..............................78

Relation of load to streamflow................................................................78

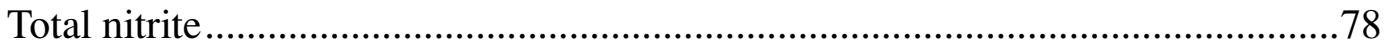

Relation of trends in concentration to flow conditions ................................80

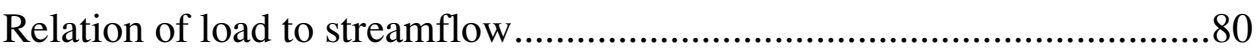

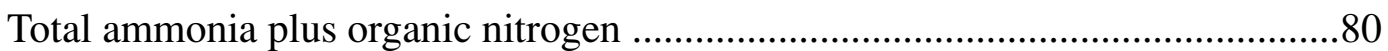

Relation of trends in concentration to flow conditions ...............................8 80

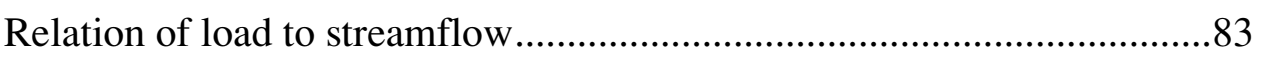

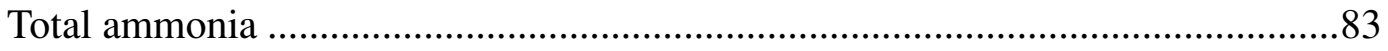

Relation of trends in concentration to flow conditions ...............................84

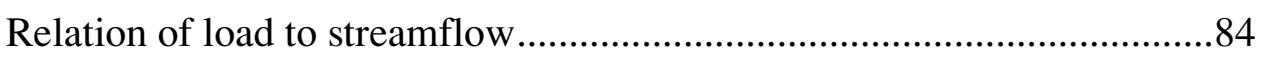

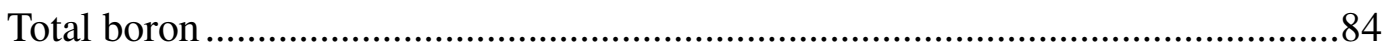

Relation of trends in concentration to flow conditions ................................84 


\section{CONTENTS--Continued}

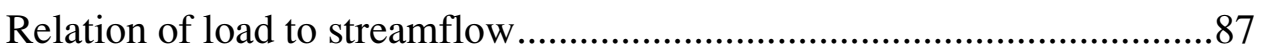

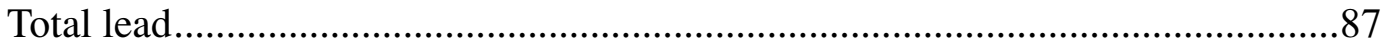

Relation of trends in concentration to flow conditions ................................87

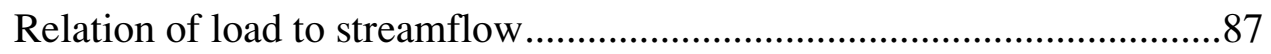

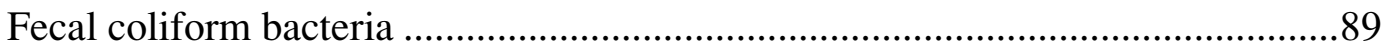

Relation of trends in concentration to flow conditions ................................89

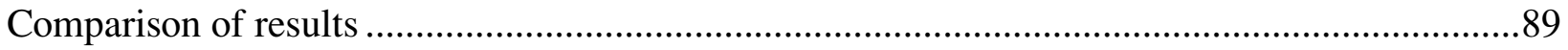

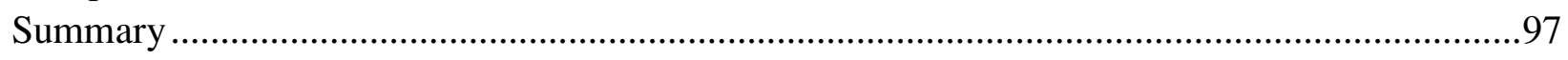

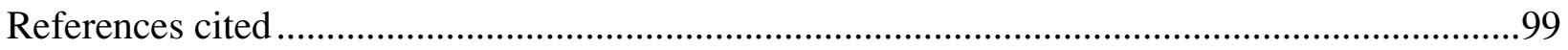

Appendixes 1-18: Relations of constituent to streamflow: (Available on CD-ROM from

U.S. Geological Survey, New Jersey District (609-771-3900))

1. Alkalinity

2. Hardness.

3. Total organic carbon

4. Suspended sediment

5. Dissolved solids

6. Dissolved sodium

7. Dissolved chloride

8. Dissolved oxygen

9. Fraction of dissolved oxygen at saturation

10. Total phosphorus.

11. Total nitrogen

12. Total nitrate plus nitrite

13. Total nitrite

14. Total ammonia plus organic nitrogen.

15. Total ammonia

16. Total boron

17. Total lead

18. Fecal coliform bacteria

\section{ILLUSTRATIONS}

Figure 1. Map showing four watershed regions in New Jersey

2. Graph showing hypothetical logarithmic plot of expected load-to-streamflow relations for a stream strongly affected by constant (point source and ground water) and intermittent (nonpoint storm runoff) sources

3. Graphs showing example plot of relation of instream load of total nitrogen to instantaneous streamflow at water-quality stations in the Rockaway River Basin, N.J., 1985-91

4. Map showing locations of surface-water-quality stations and ambient biomonitoring network stations in the Hackensack River Basin, New Jersey 


\section{ILLUSTRATIONS--Continued}

Page

Figure 5. Map showing locations of surface-water-quality stations and ambient biomonitoring network stations in the Passaic River Basin, New Jersey .......................................11

6. Map showing locations of surface-water-quality stations and ambient biomonitoring network stations in the Elizabeth and Rahway River Basins, New Jersey .............12

7. Period of record of water-quality data for selected stations in the Hackensack, Passaic, Elizabeth, and Rahway River Basins, New Jersey, for water years 1976-93

8. Example page from Appendix 14 of graphs showing relation of concentration to streamflow, relation of load to streamflow, and trends in low- and high-flow concentrations for total ammonia plus organic nitrogen at a station on the Passaic River at Little Falls, New Jersey, for water years 1976-93.

9. Schematics showing trends in alkalinity concentrations during (A) high- and (B) low-flow conditions, and (C) relative slope of alkalinity load to streamflow at surface-water-quality stations in the Hackensack, Passaic, Elizabeth, and Rahway River Basins, N.J., water years 1976-93.

10. Schematics showing trends in hardness concentrations during (A) high- and (B) low-flow conditions, and (C) relative slope of hardness load to streamflow at surface-water-quality stations in the Hackensack, Passaic, Elizabeth, and Rahway River Basins, N.J., water years 1976-93.

11. Schematics showing trends in total organic carbon concentrations during (A) highand (B) low-flow conditions, and (C) relative slope of total organic carbon load to streamflow at surface-water-quality stations in the Hackensack, Passaic, Elizabeth, and Rahway River Basins, N.J., water years 1976-93.

12. Schematics showing trends in suspended sediment concentrations during (A) highand (B) low-flow conditions, and (C) relative slope of suspended sediment load to streamflow at surface-water-quality stations in the Hackensack, Passaic, Elizabeth, and Rahway River Basins, N.J., water years 1976-93.

13. Schematics showing trends in dissolved solids concentrations during (A) high- and (B) low-flow conditions, and (C) relative slope of dissolved solids load to streamflow at surface-water-quality stations in the Hackensack, Passaic, Elizabeth, and Rahway River Basins, N.J., water years 1976-93.

14. Schematics showing trends in dissolved sodium concentrations during (A) highand (B) low-flow conditions, and (C) relative slope of dissolved sodium load to streamflow at surface-water-quality stations in the Hackensack, Passaic, Elizabeth, and Rahway River Basins, N.J., water years 1976-93.

15. Schematics showing trends in dissolved chloride concentrations during (A) high- and

(B) low-flow conditions, and (C) relative slope of dissolved chloride load to streamflow at surface-water-quality stations in the Hackensack, Passaic, Elizabeth, and Rahway River Basins, N.J., water years 1976-93 


\section{ILLUSTRATIONS--Continued}

Page

Figure 16. Schematics showing trends in dissolved oxygen concentrations during (A) highand (B) low-flow conditions, and (C) relative slope of dissolved oxygen load to streamflow at surface-water-quality stations in the Hackensack, Passaic, Elizabeth, and Rahway River Basins, N.J., water years 1976-93

17. Schematics showing trends in fraction of dissolved oxygen at saturation concentrations during (A) high- and (B) low-flow conditions, at surface-water-quality stations in the Hackensack, Passaic, Elizabeth, and Rahway River Basins, N.J., water years 1976-93.

18. Schematics showing trends in total phosphorus concentrations during (A) highand (B) low-flow conditions, and (C) relative slope of total phosphorus load to streamflow at surface-water-quality stations in the Hackensack, Passaic, Elizabeth, and Rahway River Basins, N.J., water years 1976-93

19. Schematics showing trends in total nitrogen concentrations during (A) high- and (B) low-flow conditions, and (C) relative slope of total nitrogen load to streamflow at surface-water-quality stations in the Hackensack, Passaic, Elizabeth, and Rahway River Basins, N.J., water years 1976-93

20. Schematics showing trends in total nitrate plus nitrite concentrations during (A) high- and (B) low-flow conditions, and (C) relative slope of nitrate plus nitrite load to streamflow at surface-water-quality stations in the Hackensack,

Passaic, Elizabeth, and Rahway River Basins, N.J., water years 1976-93 .79

21. Schematics showing trends in total nitrite concentrations during (A) high- and (B) low-flow conditions, and (C) relative slope of total nitrite load to streamflow at surface-water-quality stations in the Hackensack, Passaic, Elizabeth, and Rahway River Basins, N.J., water years 1976-93.

22. Schematics showing trends in total ammonia plus organic nitrogen concentrations during (A) high- and (B) low-flow conditions, and (C) relative slope of total ammonia plus organic nitrogen load to streamflow at surface-water-quality stations in the Hackensack, Passaic, Elizabeth, and Rahway River Basins, N.J., water years 1976-93....

23. Schematics showing trends in total ammonia concentrations during (A) high- and

(B) low-flow conditions, and (C) relative slope of total ammonia load to streamflow at surface-water-quality stations in the Hackensack, Passaic, Elizabeth, and Rahway River Basins, N.J., water years 1976-93.

24. Schematics showing trends in total boron concentrations during (A) high- and (B) low-flow conditions, and (C) relative slope of total boron load to streamflow at surface-water-quality stations in the Hackensack, Passaic, Elizabeth, and Rahway River Basins, N.J., water years 1976-93.

25. Schematics showing trends in total lead concentrations during (A) high- and

(B) low-flow conditions, and (C) relative slope of total lead load to streamflow relations at surface-water-quality stations in the Hackensack, Passaic, Elizabeth, and Rahway River Basins, N.J., water years 1976-93. 


\section{ILLUSTRATIONS--Continued}

Page

Figure 26. Schematics showing trends in fecal coliform bacteria concentrations during (A) high- and (B) low-flow conditions, at surface-water-quality stations in the Hackensack, Passaic, Elizabeth, and Rahway River Basins, N.J., water years $1976-93$

\section{TABLES}

Table 1. Description of, years of record for, and mean annual flow at, selected stations in the Hackensack, Passaic, Elizabeth, and Rahway River Basins, N.J. ...........................8

2. Selected constituents and reporting units .16

3. Estimated flow-duration values of mean daily discharge and data source for surface-water-quality stations in the Hackensack, Passaic, Elizabeth, and Rahway River Basins, N.J.

4. Estimated detection limits for selected constituents measured in the Hackensack,

Passaic, Elizabeth, and Rahway River Basins, N.J., water years 1976-93

Tables 5-23 Water quality and AMNET impairment status at water-quality stations

a. Median concentrations, relations of concentration and load to streamflow, and directions of concentration trends for selected water-quality constituents (at indicated station)

5. $\quad 01377000$, Hackensack River at Rivervale, N.J. .......................................32

6. 01379000, Passaic River near Millington, N.J.........................................34

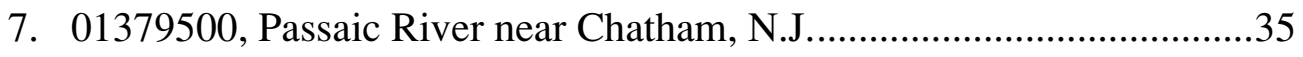

8. 01382000, Passaic River at Two Bridges, N.J..........................................36

9. 01380500, Rockaway River above Reservoir, at Boonton, N.J. ...............37

10. 01381200, Rockaway River at Pine Brook, N.J.....................................38

11. 01381500, Whippany River at Morristown, N.J. ....................................

12. 01381800, Whippany River near Pine Brook, N.J...................................

13. 01382500, Pequannock River at Macopin Intake Dam, N.J. ....................43

14. 01387500 , Ramapo River near Mahwah, N.J..........................................4

15. 01388000, Ramapo River at Pompton Lakes, N.J......................................45

16. 01388600, Pompton River at Packanack Lake, N.J. .................................46

17. 01389005, Passaic River below Pompton River, at Two Bridges, N.J....48

18. 01389500, Passaic River at Little Falls, N.J............................................49

19. 01389880, Passaic River at Route 46 at Elmwood Park, N.J...................50

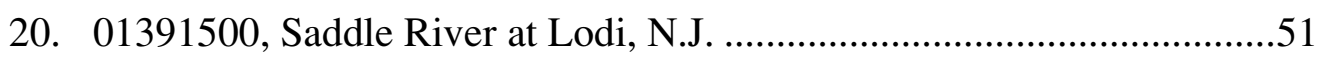

21. 01393450, Elizabeth River at Ursino Lake, at Elizabeth, N.J..................53

22. 01394500, Rahway River near Springfield, N.J...................................54

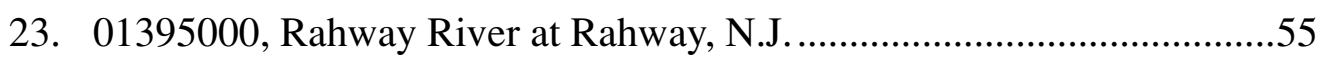




\section{TABLES--Continued}

Page

Tables 5-23

b. 1993 AMNET impairment status (in the vicinity of station)

5. 01377000, Hackensack River at Rivervale, N.J. .....................................32

6. 01379000, Passaic River near Millington, N.J..........................................34

7. 01379500, Passaic River near Chatham, N.J..............................................35

8. 01382000, Passaic River at Two Bridges, N.J.............................................36

9. 01380500, Rockaway River above Reservoir, at Boonton, N.J. ..............37

10. 01381200, Rockaway River at Pine Brook, N.J......................................38

11. 01381500, Whippany River at Morristown, N.J. .....................................40

12. 01381800, Whippany River near Pine Brook, N.J...................................41

13. 01382500, Pequannock River at Macopin Intake Dam, N.J. ...................43

14. 01387500, Ramapo River near Mahwah, N.J...........................................4

15. 01388000, Ramapo River at Pompton Lakes, N.J....................................45

16. 01388600, Pompton River at Packanack Lake, N.J. ................................46

17. 01389005, Passaic River below Pompton River, at Two Bridges, N.J....48

18. 01389500, Passaic River at Little Falls, N.J...........................................49

19. 01389880, Passaic River at Route 46, at Elmwood Park, N.J..................50

20. 01391500, Saddle River at Lodi, N.J. ...................................................51

21. 01393450, Elizabeth River at Ursino Lake, at Elizabeth, N.J.................53

22. 01394500, Rahway River near Springfield, N.J...................................54

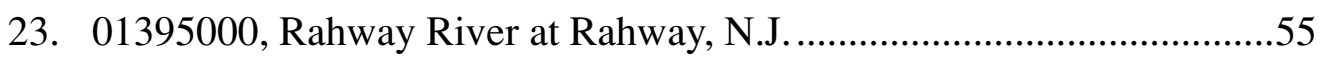

24. Concentration trends during low flow at surface-water-quality stations in the Hackensack, Passaic, Elizabeth, and Rahway River Basins, N.J., water years 1976-93

25. Concentration trends during high flow at surface-water-quality stations in the Hackensack, Passaic, Elizabeth, and Rahway River Basins, N.J., water years 1976-93

26. Seasonal dependency at surface-water-quality stations in the Hackensack, Passaic, Elizabeth, and Rahway River Basins, N.J., water years 1976-93...

27. Maximum, minimum, and spread of load-to-streamflow slopes for selected constituents at surface-water-quality monitoring stations in the Hackensack, Passaic, Elizabeth, and Rahway River Basins, N.J., water years 1976-93

28. Maximum, minimum, and spread of load-to-streamflow slopes for selected nutrients at surface-water-quality stations in the Hackensack, Passaic, Elizabeth, and Rahway River Basins, N.J., water years 1976-93 


\section{CONVERSION FACTORS AND ABBREVIATED WATER-QUALITY UNITS}

Multiply

mile (mi) $\underline{\text { By }}$

$\underline{\text { To obtain }}$

$\underline{\text { Length }}$

$$
1.609
$$

$\underline{\text { Area }}$

square mile $\left(\mathrm{mi}^{2}\right)$

square mile $\left(\mathrm{mi}^{2}\right)$

259.0

2.590

$\underline{\text { Volume }}$

gallon (gal) gallon (gal)

cubic foot $\left(\mathrm{ft}^{3}\right)$

cubic foot per second $\left(\mathrm{ft}^{3} / \mathrm{s}\right)$

pounds per day (lb/d)

3.785

0.003785

0.02832

Flow

$$
0.02832
$$

0.4536

$\underline{\text { Mass }}$

pound, avoirdupois (lb) hectare

square kilometer

kilometer

liter

cubic meter

cubic meter

Temperature given in degrees Fahrenheit $\left({ }^{\circ} \mathrm{F}\right)$ and Celsius $\left({ }^{\circ} \mathrm{C}\right)$ may be converted to degrees Celsius $\left({ }^{\circ} \mathrm{C}\right)$ and Kelvin $\left({ }^{\circ} \mathrm{K}\right)$ by the following equations:

$$
\begin{aligned}
& { }^{\circ} \mathrm{C}=5 / 9 \times\left({ }^{\circ} \mathrm{F}-32\right) \\
& { }^{\circ} \mathrm{K}=273.15+{ }^{\circ} \mathrm{C}
\end{aligned}
$$

\begin{tabular}{|c|c|c|c|}
\hline$\mu \mathrm{m}$ & - micrometer & DO & - dissolved oxygen \\
\hline $\mathrm{s} / \mathrm{d}$ & - seconds per day & FDO & - fraction of dissolved oxygen \\
\hline $\mathrm{mg} / \mathrm{L}$ & - milligrams per liter & & at saturation \\
\hline$\mu \mathrm{g} / \mathrm{L}$ & - micrograms per liter & $\mathrm{TP}$ & - total phosphorus \\
\hline $\mathrm{MPN} / 10$ & $\begin{array}{l}\text { - most probable number of } \\
\text { bacteria per } 100 \text { milliliters }\end{array}$ & $\begin{array}{l}\mathrm{TN} \\
\mathrm{NO} 32\end{array}$ & $\begin{array}{l}\text { - total nitrogen } \\
\text { - total nitrate plus nitrite }\end{array}$ \\
\hline ALK & - alkalinity & $\mathrm{NO} 2$ & - total nitrite \\
\hline HARD & - hardness & TAON & - total ammonia plus organic \\
\hline TOC & - total organic carbon & & nitrogen \\
\hline SS & - suspended sediment & NH4 & - total ammonia \\
\hline DS & - dissolved solids & $\mathrm{B}$ & - total boron \\
\hline NA & - dissolved sodium & $\mathrm{PB}$ & - total lead \\
\hline $\mathrm{CL}$ & - dissolved chloride & BACT & - fecal coliform bacteria \\
\hline
\end{tabular}

\section{$\underline{\text { Water-quality abbreviations }}$}




\title{
RELATIONS OF SURFACE-WATER QUALITY TO STREAMFLOW IN THE HACKENSACK, PASSAIC, ELIZABETH, AND RAHWAY RIVER BASINS, NEW JERSEY, WATER YEARS 1976-93
}

\author{
By Debra E. Buxton, Kathryn Hunchak-Kariouk, and R. Edward Hickman
}

\begin{abstract}
Relations of water quality to streamflow were determined for 18 water-quality constituents at 19 surface-water-quality stations within the drainage basins of the Hackensack, Passaic, Elizabeth, and Rahway Rivers in New Jersey for water years 1976-93. Surface-waterquality and streamflow data were evaluated for trends (through time) in constituent concentrations during high and low flows, and relations between constituent concentration and streamflow, and constituent load and streamflow, were determined. Median concentrations were calculated for the entire period of study (water years 1976-93) and for the last 5 years of the period of study (water years 1989-93) to determine whether any large variation in concentration exists between the two periods. Medians also were used to determine the seasonal Kendall's tau statistic, which was then used to evaluate trends in concentrations during high and low flows.
\end{abstract}

Trends in constituent concentrations during high and low flows were evaluated to determine whether the distribution of the observations changes over time for intermittent (nonpoint storm runoff) or constant (point sources and ground water) sources, respectively. Highand low-flow concentration trends were determined for some constituents at 11 of the 19 waterquality stations; 8 stations have insufficient data to determine trends. Seasonal effects on the relations of concentration to streamflow are evident for 16 of the 18 constituents. Negative slopes of relations of concentration to streamflow, which indicate a decrease in concentration at high flows, predominate over positive slopes because of dilution of instream concentrations from storm runoff.

The slopes of the regression lines of load to streamflow were determined in order to show the relative contributions to the instream load from constant (point sources and ground water) and intermittent sources (storm runoff). Greater slope values suggest larger contributions from storm runoff to instream load, which most likely indicate an increased relative importance of nonpoint sources. Load-to-streamflow relations along a stream reach that tend to increase in a downstream direction indicate the increased relative importance of contributions from storm runoff. Likewise, load-to-streamflow relations along a stream reach that tend to decrease in a downstream direction indicate the increased relative importance of point sources and ground-water discharge.

For most of the 18 constituents, load-to-streamflow relations at stations along a river reach remain constant or decrease in a downstream direction. The slopes increase in the downstream direction for some or all of the nutrient species at the Ramapo, lower Passaic, and Rahway Rivers; for dissolved solids, dissolved sodium, and dissolved chloride at the lower Passaic River; and for alkalinity and hardness at the Rahway River. 


\section{INTRODUCTION}

The New Jersey Department of Environmental Protection (NJDEP) has initiated an innovative watershed approach to water-quality management in order to attain State-mandated goals for the quality of surface water (New Jersey Department of Environmental Protection, 1989). Water quality will be assessed and management polices will be developed on the basis of factors that adversely affect quality, such as nonpoint source contributions, headwaters destruction, and habitat degradation, within the watershed or basin. This approach requires evaluation of the effects of point and nonpoint source contributions on the quality of surface water within a watershed. To facilitate the assessment of surface-water quality, the State is divided into four regions on the basis of watershed-management issues and hydrogeologic boundaries defined by the U.S. Geological Survey (USGS) (fig. 1).

The USGS, in cooperation with the NJDEP, has developed a watershed-based method for relating water quality to streamflow to assess the relative contributions of constant (point sources and ground-water discharge) and intermittent (nonpoint storm runoff) sources of constituents to New Jersey streams in all four regions. This initial study was conducted by using a watershedbased method for the Passaic region comprising the Hackensack, Passaic, Elizabeth, and Rahway River Basins (referred to as the study area). The other regions consist of (1) the Wallkill River and upper Delaware River Basins; (2) the Raritan River Basin; and (3) the Atlantic Coastal, lower Delaware River, and Delaware Bay Basins.

\section{Purpose and Scope}

This report presents the results of analyses for 18 water-quality constituents in samples collected at 19 surface-water-quality stations within the study area during water years ${ }^{1}$ 1976-93 (October 1, 1975, through September 30, 1993). Relations between each of the 18 constituents and streamflow at the 19 stations over the period of record are determined by testing for trends in the concentrations of constituents during low and high flows. Qualitative values of contributions from constant (point sources and ground water) and intermittent (nonpoint storm runoff) sources are estimated statistically by examining the relations between concentrations of constituents and streamflow, and load and streamflow.

Results of analyses are presented in three ways - in tables for each station with median concentrations, the regression slopes of concentration and load to streamflow, and the directions of the trends in concentrations during low and high flows for all constituents; in schematics for each constituent showing regional trends in concentration during low and high flows and the slopes of load to streamflow; and in graphs for each constituent by station showing relations of concentration to streamflow, load to streamflow, and trends in concentrations during low and high flows.

\footnotetext{
${ }^{1}$ A water year is the 12-month period from October 1 through September 30 and is designated by the calendar year in which it ends.
} 


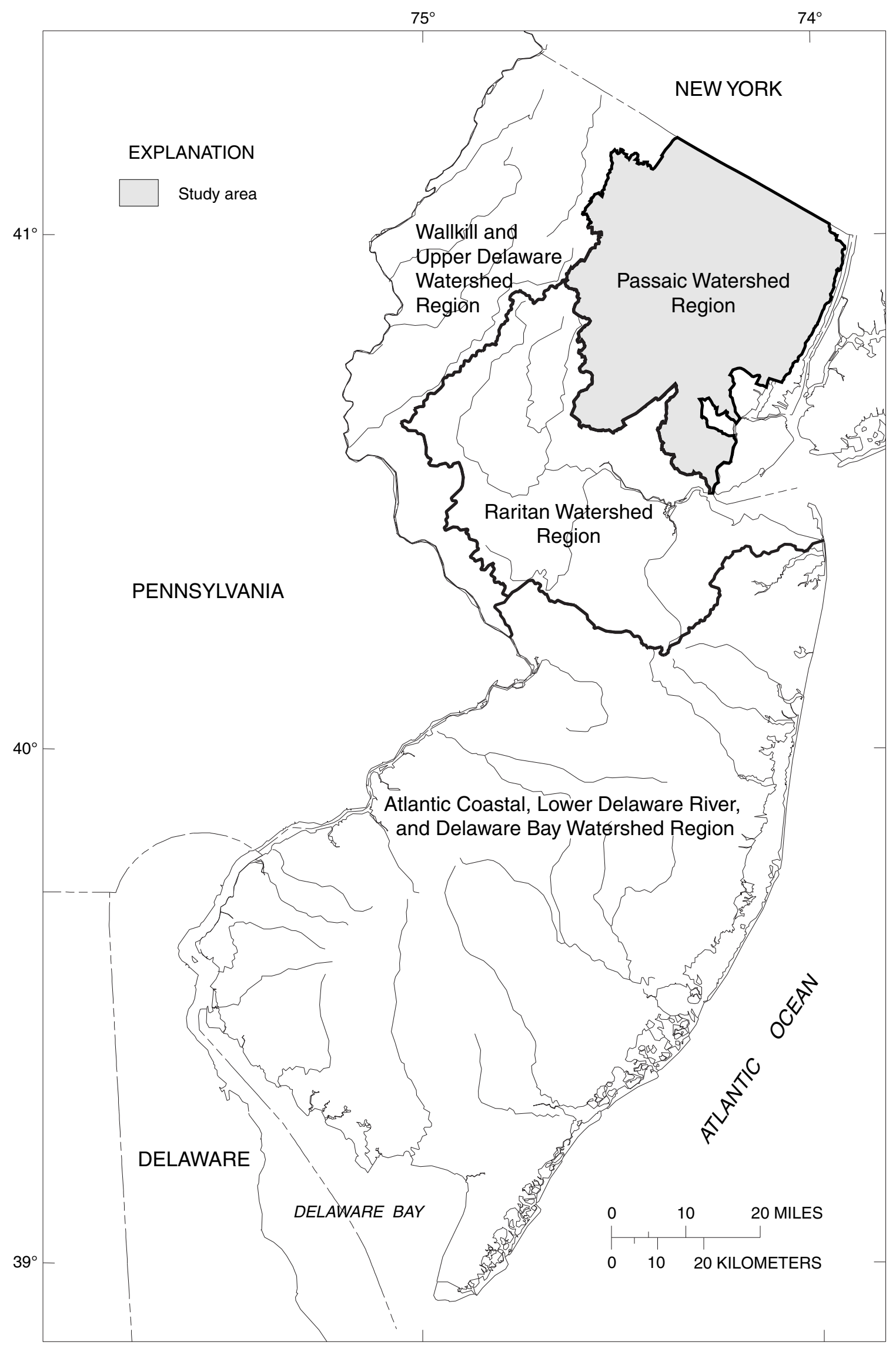

Figure 1. Four watershed regions in New Jersey. 


\section{Approach}

A river receives constituents from point and nonpoint sources within the contributing drainage basin. Point sources are discrete, identifiable origins of constituents, such as permitted discharges from municipal- and industrial-wastewater treatment facilities, that contribute water to a stream at a constant rate, independent of streamflow conditions. Constituents from more diffuse, nonpoint sources are transported to the river by storm runoff from agricultural, residential, and urban areas and impervious surfaces (highways and parking lots), and by ground water that could contain effluent from leaking underground-storage tanks, septic systems, and landfills. Storm runoff, composed of overland runoff (water that flows overland when precipitation exceeds the infiltration rate) and interflow (infiltrated water that moves in a horizontal direction in the low permeable subsoil), contributes to a stream intermittently, depending on storm intensity and frequency, and only during high flows (Chow, 1964; Novotny and Chesters, 1981). Ground-water discharge to a stream is almost constant, varying slightly with season and precipitation rate. Instream concentrations of constituents are a summation of the contributions from constant (point sources and ground-water discharge) and intermittent (storm runoff) sources.

The magnitude or steepness of the regression slope of constituent loads to streamflow indicates the relative contributions of constant and intermittent sources at a river location. The steeper the slope, the greater the contribution from nonpoint sources during increased streamflow. If the contributions to instream load are mainly from point sources and ground water, instream load will remain constant with increasing streamflow, and the regression slope of load to streamflow will be approximately zero (fig. 2). If, however, storm runoff contributes a disproportional amount to instream load, instream load will increase with increasing streamflow, and the regression slope of load to streamflow will be greater than zero (fig. 2). A steep slope does not imply that contributions from constant sources are unimportant, just that intermittent sources contribute more to instream load during high flows than do constant sources. Price and Schaefer (1995) used this approach (steepness of the load-to-streamflow regression line) to assess the relative contributions of permitted and nonpermitted sources in the Musconetcong, Rockaway, and Whippany River Basins. An idealized example of the relation of load to streamflow is shown in figure 3. For site 01380500 , the Rockaway River above the reservoir at Boonton, the slope of the regression line is steeper (the estimated total median load from permitted point sources upstream was approximately $100 \mathrm{lb} / \mathrm{d}$ ) than the slope for site 01381200 , Rockaway River at Pine Brook (the estimated median load from permitted point sources was approximately 1,000 lb/d). In the example, the relative importance of nonpoint sources is greater at station 01380500 than at site 01381200 , and the relative importance of point sources is greater at site 01381200 than at site 01380500 .

Concentrations cannot be related to streamflow in this way because contributions from storm runoff are flow dependent, and a small concentration can represent a large instream load during high-flow conditions. If constituents are contributed to a stream mostly from constant sources, then instream concentrations will be diluted during periods of high flow. If, however, storm runoff contributes significant amounts of constituents to a stream, then the extent of dilution 


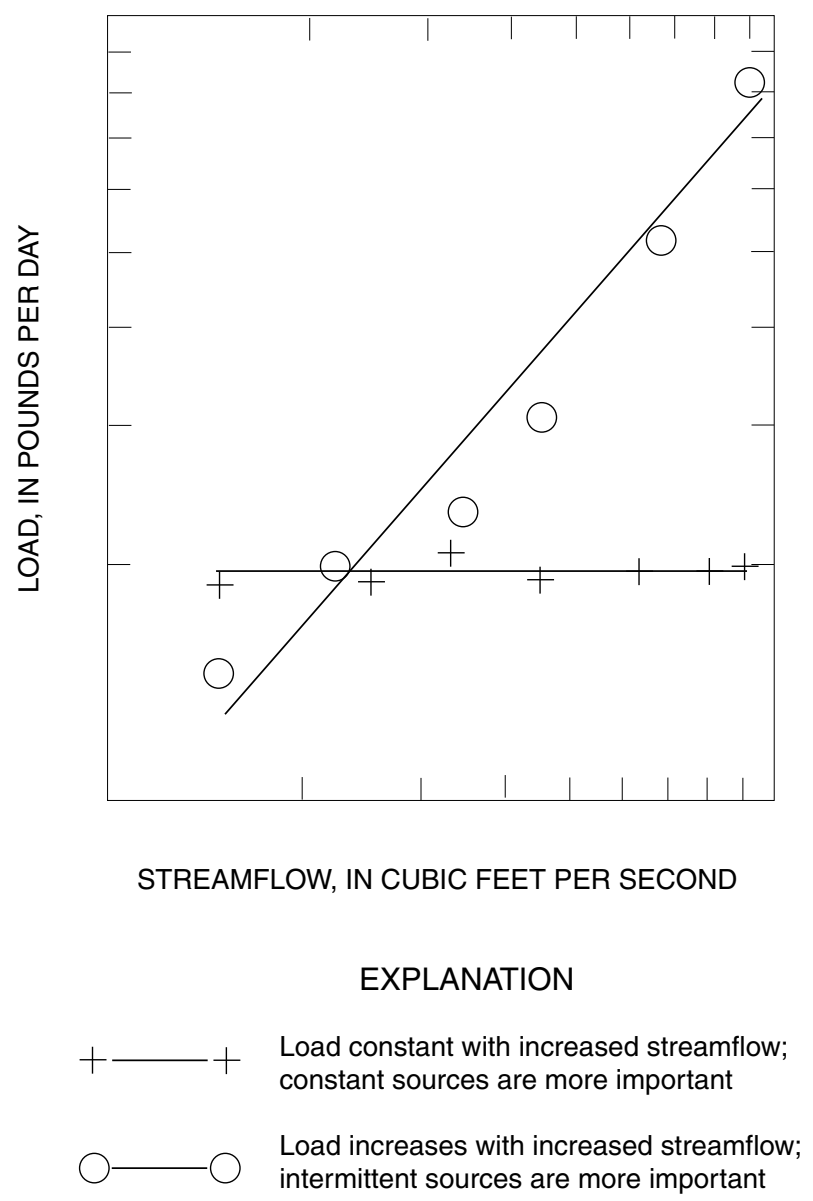

Figure 2. Hypothetical logarithmic plot of expected load-to-streamflow relations for a stream strongly affected by constant (point source and ground water) and intermittent (nonpoint storm runoff) sources. 


\section{PERCENTAGE OF TIME INDICATED FLOW IS EXCEEDED}

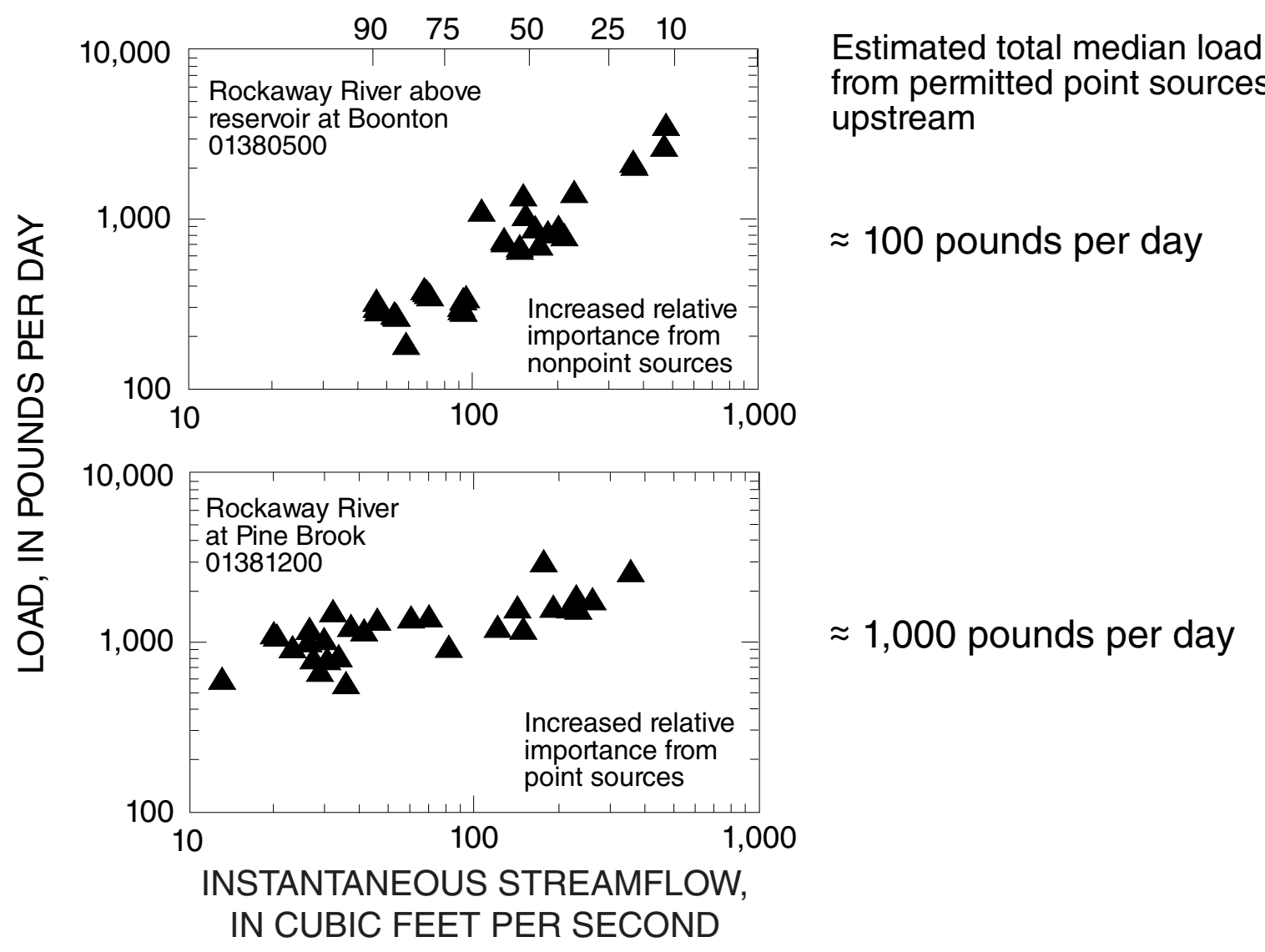

\section{EXPLANATION}

A Water-quality sample

Figure 3. Relation of instream load of total nitrogen to instantaneous streamflow at water-quality stations in the Rockaway River Basin, New Jersey, 1985-91. 
during periods of high flow will be reduced. The use of loads (mass per time) instead of concentrations (mass per volume) removes the influence of changing streamflow (volume per time) on instream constituent amounts.

The instream load also can be affected by contributions from ground water and streambed sediment. Ground-water contributions to streams during low flow can be significant, but are less likely to affect surface-water quality during high-flow conditions when ground-water contributions are diluted. In some hydrologic systems, the scour of streambed sediment during high flows can contribute to the instream load. Rosensteel and Strom (1991) collected waterquality samples from the Pompton and Passaic Rivers during storms and found that most of the observed increase in the load of total phosphorus at high flows was attributable to the dissolved fraction of the phosphorus load, indicating that the load contributed by sediment scour probably was significant.

Comparisons of trends in constituent concentrations during high and low flows can indicate changes over time in the contributions from intermittent and constant sources, respectively. Positive trends during high flows indicate an increase in the storm runoff contributions over time, whereas negative trends indicate a decrease in the storm runoff contributions. Positive trends during low flows indicate an increase in the contributions from point sources and ground-water or both over time, whereas negative trends indicate a decrease in the contributions from point sources and ground water.

The study involved several phases of multidisciplinary activity starting with the selection of the surface-water-quality stations (table 1), constituents, and the period of record. Waterquality and instantaneous-streamflow data were retrieved from the National Water Information System (NWIS) data base (Hutchison, 1975), which is maintained by the USGS. The waterquality and instantaneous-streamflow data underwent extensive quality-assurance procedures.

The data base created for this study was maintained with the Statistical Analysis System (SAS), a statistically based integrated software system that provides data access, management, analysis, and presentation. With SAS, median concentrations and relations of surface-water quality to streamflow were determined for each constituent at each station. The types of relations analyzed are concentration to streamflow, load to streamflow, and concentration trends during low- and high-flow conditions.

Graphs, schematics, and tables were generated to show the statistical results. Results are presented in the text first by basin and compared with the impairment index generated by the NJDEP's Ambient Biomonitoring Network (AMNET) biological assessment, then by constituent. Results of the three surface-water quality to streamflow analyses are presented graphically by constituent for each station in appendixes $1-18^{2}$.

\footnotetext{
${ }^{2}$ Appendixes 1-18 containing relations of surface-water quality to streamflow are available on a CD-ROM;
} contact the New Jersey District Office of the USGS in West Trenton, N.J., for more information. 
Table 1. Description of, years of record for, and mean annual flow at, selected stations in the Hackensack, Passaic, Elizabeth, and Rahway River Basins, N.J.

[ND, no data for site; $\mathrm{mi}^{2}$, square miles; $\mathrm{ft}^{3} / \mathrm{s}$, cubic feet per second]

\begin{tabular}{|c|c|c|c|c|c|}
\hline $\begin{array}{l}\text { Station } \\
\text { number }\end{array}$ & Station name & $\begin{array}{l}\text { Latitude/ } \\
\text { longitude }\end{array}$ & $\begin{array}{l}\text { Drain- } \\
\text { age } \\
\text { area in } \\
\mathrm{mi}^{2}\end{array}$ & $\begin{array}{l}\text { Streamflow } \\
\text { record } \\
\text { (water years) }\end{array}$ & $\begin{array}{l}\text { Mean } \\
\text { annual flow } \\
\text { in } \mathrm{ft}^{3} / \mathrm{s} \\
\text { (period of } \\
\text { record) }\end{array}$ \\
\hline \multicolumn{6}{|c|}{ Hackensack River Basin } \\
\hline 01377000 & Hackensack River at Rivervale & $405955 / 735927$ & 58.0 & $1942-93$ & 88.5 \\
\hline \multicolumn{6}{|c|}{$\underline{\text { Passaic River Basin }}$} \\
\hline 01379000 & Passaic River near Millington & $404048 / 743145$ & 55.4 & 1904-93 & 91.1 \\
\hline 01379500 & Passaic River near Chatham & $404331 / 742323$ & 100 & 1903-93 & 172 \\
\hline 01380500 & Rockaway River above Reservoir, at Boonton & $405410 / 742436$ & 116 & $1938-93$ & 231 \\
\hline${ }^{1} 01381200$ & Rockaway River at Pine Brook & $405129 / 742053$ & 136 & ND & ND \\
\hline 01381500 & Whippany River at Morristown & $404826 / 742722$ & 29.4 & 1922-93 & 53.8 \\
\hline${ }^{1} 01381800$ & Whippany River near Pine Brook & $405042 / 742051$ & 68.5 & ND & ND \\
\hline${ }^{1} 01382000$ & Passaic River at Two Bridges & $405340 / 741623$ & 361 & ND & ND \\
\hline 01382500 & Pequannock River at Macopin Intake Dam & $410105 / 742407$ & 63.7 & $1923-93$ & 45.6 \\
\hline 01387500 & Ramapo River near Mahwah & $410551 / 740948$ & 120 & $1903-93$ & 229 \\
\hline 01388000 & Ramapo River at Pompton Lakes & $405933 / 741644$ & 160 & $1922-93$ & 286 \\
\hline${ }^{1} 01388600$ & Pompton River at Packanack Lake & $405636 / 741647$ & 361 & ND & ND \\
\hline${ }^{1} 01389005$ & Passaic River below Pompton River, at Two Bridges & $405347 / 741610$ & 734 & ND & ND \\
\hline${ }^{2} 01389500$ & Passaic River at Little Falls & $405305 / 741335$ & 762 & $1898-93$ & 1,148 \\
\hline${ }^{1} 01389880$ & Passaic River at Route 46 at Elmwood Park & $405337 / 740746$ & 803 & ND & ND \\
\hline 01391500 & Saddle River at Lodi & $405325 / 740451$ & 54.6 & 1924-93 & 99.9 \\
\hline \multicolumn{6}{|c|}{ Elizabeth River Basin } \\
\hline 01393450 & Elizabeth River at Ursino Lake, at Elizabeth & $404030 / 741320$ & 16.9 & $1922-93$ & 25.8 \\
\hline \multicolumn{6}{|c|}{$\underline{\text { Rahway River Basin }}$} \\
\hline 01394500 & Rahway River near Springfield & $404111 / 741844$ & 25.5 & $1939-93$ & 29.4 \\
\hline 01395000 & Rahway River at Rahway & $403705 / 741700$ & 40.9 & $1922-93$ & 48.0 \\
\hline
\end{tabular}

${ }^{1}$ Water-quality station only.

${ }^{2}$ NASQAN (National Stream Quality Accounting Network) station. 


\section{Description of the Study Area}

The study area is located in northeastern New Jersey and encompasses four river basinsthe Hackensack, Passaic, Elizabeth, and Rahway (figs. 4, 5, and 6).

\section{Hackensack River Basin}

The Hackensack River (fig. 4) drains an area of $202 \mathrm{mi}^{2}$, extends 35 miles in a southerly direction from the headwaters in New York State through Bergen and Hudson Counties in New Jersey, and discharges into Newark Bay (Bartlett, 1984). The river's major tributaries in New Jersey include Pascack, Berrys, Overpeck, and Wolf Creeks. The major impoundments on the river are Oradell Reservoir, Lake Tappan, and Woodcliff Reservoir. Mean annual flow for water years 1942-93 is estimated to be $88.5 \mathrm{ft}^{3} / \mathrm{s}$ at the surface-water gaging station at Rivervale (01377000) (Bauersfeld and others, 1994). The only water-quality station on the river is at Rivervale (01377000) where the period of record for water-quality data is water years 1962 and 1964 through 1993 (Bauersfeld and others, 1994). Land use in the watershed is diverse, about 50 percent undeveloped and slightly more than 30 percent residential. The remainder is commercial/ industrial (New Jersey Department of Environmental Protection and Energy, 1993).

\section{Passaic River Basin}

The Passaic River (fig. 5), the longest river in New Jersey, extends almost 100 miles from its source near Morristown to its discharge point in Newark Bay (Bartlett, 1984). The drainage basin covers about $926 \mathrm{mi}^{2}$, including parts of seven New Jersey counties-Morris, Sussex, Somerset, Essex, Passaic, Bergen, and Hudson. Major tributaries include the Whippany, Rockaway, Pequannock, Ramapo, Pompton, and Saddle Rivers. The impoundments along the river and tributaries include Canoe Brook, Clyde Potts, Boonton, Charlotteburg, and Wanaque Reservoirs. A mean annual flow of $1,148 \mathrm{ft}^{3} / \mathrm{s}$ is estimated for water years $1989-93$ on the Passaic River at Little Falls (01389500) (Bauersfeld and others, 1994).

The Passaic River Basin contains 15 water-quality stations (table 1). Six water-quality stations are located on the Passaic River, one of which, Passaic River at Little Falls (01389500), is a National Stream Quality Accounting Network (NASQAN) station. The Rockaway, Whippany, and Ramapo Rivers each have two water-quality stations located along their reaches. One station is located on each of the Pequannock, Pompton, and Saddle Rivers. The period of record for water-quality-data collection for each station is shown in figure 7. For this report, the Passaic River above Two Bridges, N.J., is called the upper Passaic River; below Two Bridges, the Passaic River is called the lower Passaic River.

Land use in the upper part of the basin, above water-quality station 01382000 (Passaic River at Two Bridges) is 50 percent undeveloped and 50 percent residential and commercial; significant development is expected. Land use in the lower part of the basin, from Two Bridges to Newark Bay, is dominated by the extensive development of older cities with many industrial and commercial areas (New Jersey Department of Environmental Protection, 1993). 


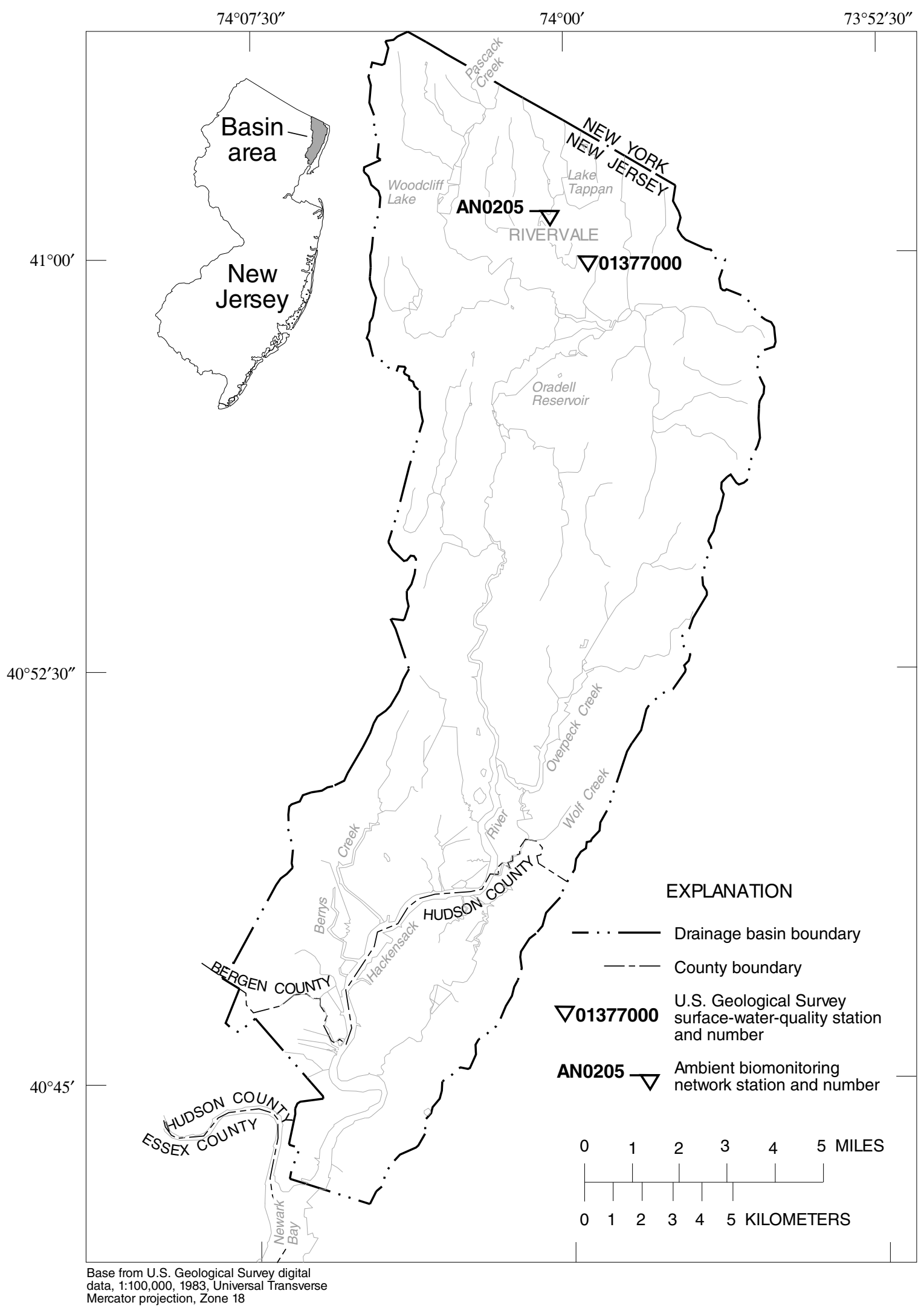

Figure 4. Locations of surface-water-quality stations and ambient biomonitoring network stations in the Hackensack River Basin, New Jersey. 


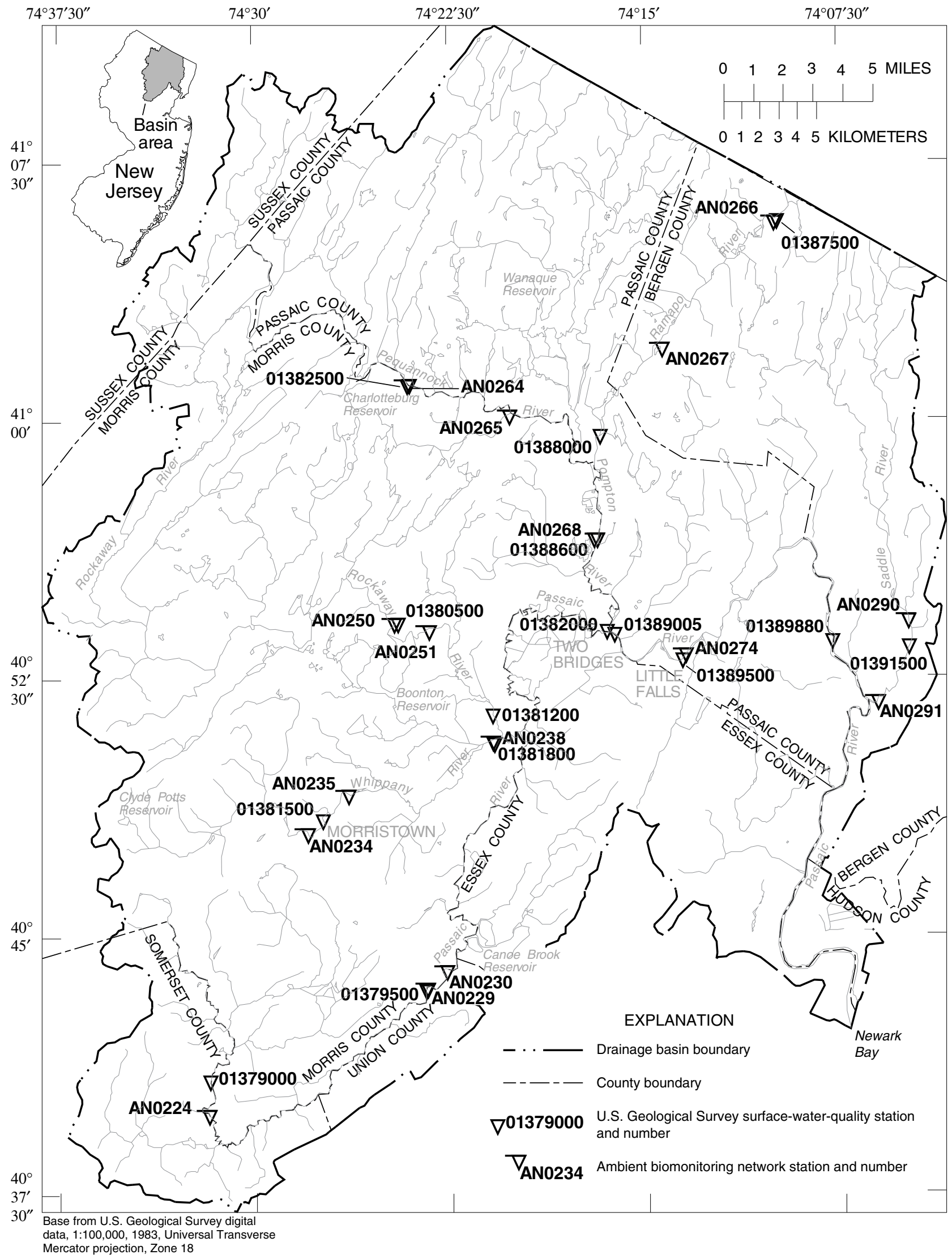

Figure 5. Locations of surface-water-quality stations and ambient biomonitoring network stations in the Passiac River Basin, New Jersey. 


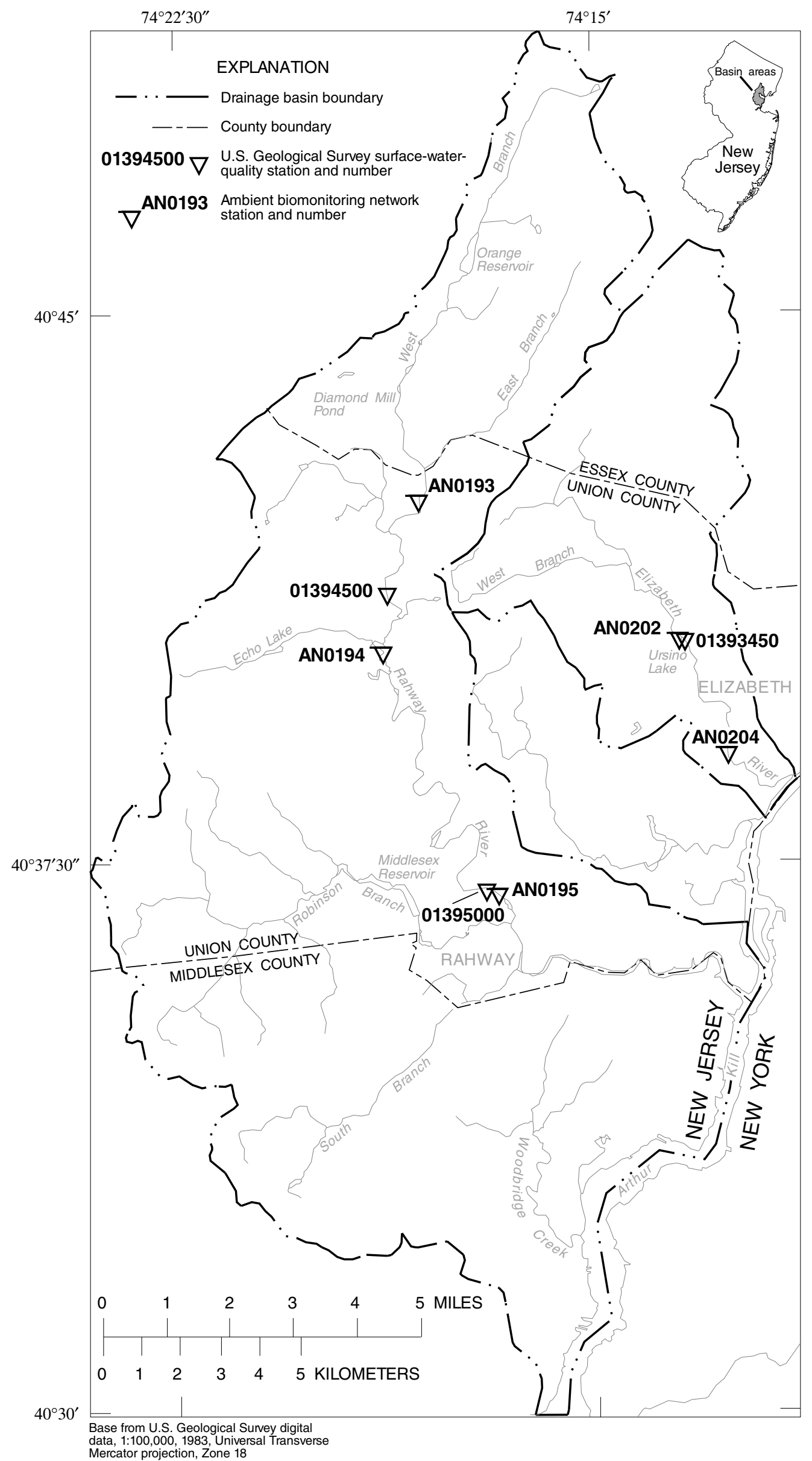

Figure 6. Locations of surface-water-quality stations and ambient biomonitoring network stations in the Elizabeth and Rahway River Basins, New Jersey. 


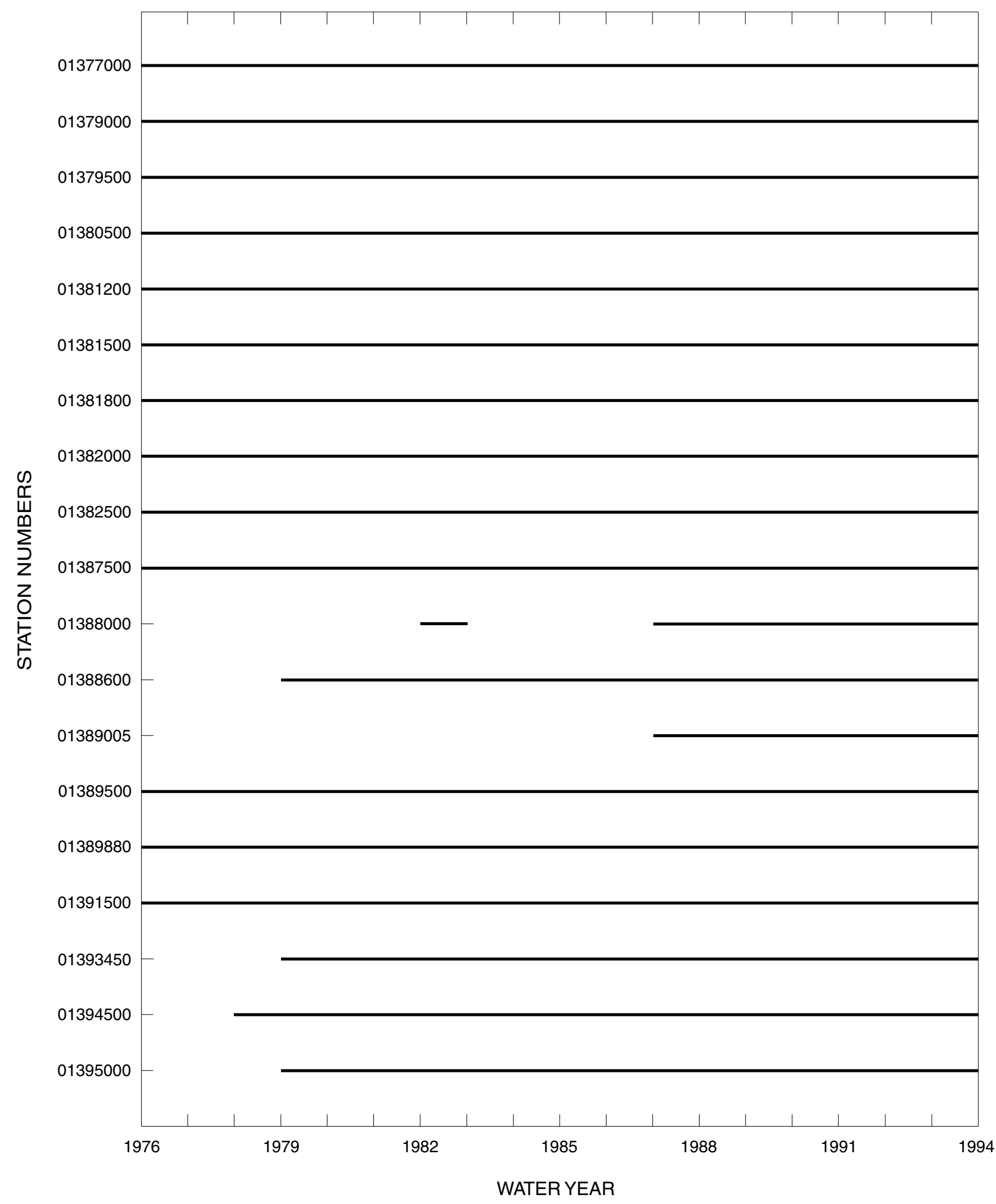

Figure 7. Period of record (at least one measurement per year) of water-quality data for selected stations in the Hackensack, Passaic, Elizabeth, and Rahway River Basins, New Jersey, for water years 1976-93. (Station names are given in table 1.) 


\section{Elizabeth River Basin}

The Elizabeth River (fig. 6) has a drainage area of about $23.4 \mathrm{mi}^{2}$ and flows for 11 miles through Essex and Union Counties to its discharge point at Arthur Kill. The main tributary is the West Branch Elizabeth River, and Ursino Lake is the only impoundment. Mean annual flow is estimated to be $25.8 \mathrm{ft}^{3} / \mathrm{s}$ for water years 1922 through 1993 at Ursino Lake at Elizabeth (01393450) (Bauersfeld and others, 1994).

The water-quality station located on the Elizabeth River at Ursino Lake has a period of record from water year 1979 through 1993 (fig. 7). Land use throughout the basin is mainly residential, commercial, and industrial. Most of the river is channelized for flood-control purposes in the highly developed urban areas (New Jersey Department of Environmental Protection and Energy, 1993).

\section{Rahway River Basin}

The mainstem of the Rahway River (fig. 6) flows for 24 miles from the headwaters in Essex County, through Union and Middlesex Counties, to its discharge point at Arthur Kill. The river drains an area of about $82.7 \mathrm{mi}^{2}$. Major tributaries include East Branch Rahway River, Robinson Branch, South Branch, and Woodbridge River. Impoundments along the mainstem and tributaries include Middlesex and Orange Reservoirs, Echo Lake, and Diamond Mill Pond. The estimated mean annual flow for water years 1922 through 1993 is $48.0 \mathrm{ft}^{3} / \mathrm{s}$ at Rahway (01395000) (Bauersfeld and other, 1994).

Two water-quality stations with data dating back to the late 1970's are located along the reach of the Rahway River (fig. 7). The basin is densely populated and highly developed; most land use is residential, commercial, and industrial (New Jersey Department of Environmental Protection and Energy, 1993).

\section{Previous Studies}

Water-quality studies have been conducted by the USGS, in cooperation with State and local agencies, in New Jersey since the early 1960's. Three more recent USGS studies report the effects of nonpoint-source contamination on New Jersey streams. Schornick and Fishel (1980) reported the effect of storm runoff on the surface-water quality of the Mill Creek Basin in Willingboro, Burlington County. Fusillo (1981) reported the effects of suburban residential development on surface- and ground-water quality in the upper Great Egg Harbor River Basin in Winslow Township, Camden County. Price and Schaefer (1995) reported estimated loads of selected constituents in the Musconetcong, Rockaway, and Whippany River Basins in northern New Jersey.

Several previous studies address surface-water issues in the river basins investigated in this study. Anderson and George (1966) reported the results of a statewide reconnaissance study of the water-quality characteristics of New Jersey streams. Anderson and Faust (1973) described the characteristics of water quality and streamflow of the Passaic River Basin upstream from Little Falls, and Anderson and Faust (1974) described the water quality and streamflow 
characteristics of the Raritan River Basin. Anderson and Murphy (1970) described the quality of the water released from the Hackensack River pilot desalination plant at Jersey City. Carswell (1976) conducted an appraisal of the water resources in the Hackensack River Basin. Schaefer and others (1993), Geonics, Ltd. (1979), and Canace and others (1983) described the hydrologic system of the upper Rockaway River Basin. Rosensteel and Strom (1991) compared phosphorus loads in stormwater collected near the confluence of the Passaic and Pompton Rivers with phosphorus loads in the streams. Vecchioli and Miller (1974) described the surface-water and ground-water systems of the Ramapo River Basin.

Several USGS studies were conducted to evaluate surface-water characteristics and waterquality trends in New Jersey. Low-flow characteristics and flow durations of New Jersey streams were reported by Gillespie and Schopp (1982). Hay and Campbell (1990) identified statewide water-quality trends in New Jersey streams. Robinson and Pak (1993) summarized the water quality of selected New Jersey streams for water years 1987-89. Statewide monthly statistical summaries of surface-water temperatures during 1955-93 were presented by Reed and HunchakKariouk (1995).

\section{$\underline{\text { Acknowledgments }}$}

The authors thank Kevin Berry and Dan VanAbs, NJDEP, Office of Environmental Planning, for their cooperation and assistance in planning this report and William Summers, USGS, for his extensive computer programing for data manipulation and schematic design.

\section{METHODS OF STUDY}

The following section describes the methods and criteria used for the selection of constituents, sites, and data sources. Methods for data preparation, quality assurance, and statistical analyses are described.

\section{Selection of Constituents, Sites, and Data Sources}

Constituents were chosen on the basis of their usefulness as indicators of the quality of the surface water and usefulness in developing effective surface-water-quality management practices. The 18 constituents selected include aggregate water properties (properties that include concentrations of several different chemical species), major ions, dissolved oxygen, nutrients, metals, and bacteria (table 2).

The four basins contain 18 water-quality stations (table 1) with data from water years 1976-93 that are part of the USGS/NJDEP Cooperative Ambient Surface Water Quality Network and one water-quality station that is part of NASQAN. Thirteen of the stations also are operated as surface-water gaging stations. These stations were chosen on the basis of their locations and periods of record. 
Table 2. Selected constituents and reporting units

[mg/L, milligrams per liter; $\mathrm{CaCO}_{3}$, calcium carbonate; $\mathrm{C}$, carbon; $\mathrm{Na}$, sodium; $\mathrm{Cl}$, chloride; $\mathrm{P}$, phosphorus; N, nitrogen; $\mu \mathrm{g} / \mathrm{L}$, micrograms per liter; $\mathrm{B}$, boron; Pb, lead; MPN/100 mL, most probable number per 100 milliliters.]

\begin{tabular}{|c|c|}
\hline Constituent & Reporting unit \\
\hline Alkalinity & $\mathrm{mg} / \mathrm{L}$ as $\mathrm{CaCO}_{3}$ \\
\hline${ }^{1}$ Hardness & $\mathrm{mg} / \mathrm{L}$ as $\mathrm{CaCO}_{3}$ \\
\hline${ }^{1}$ Total organic carbon & $\mathrm{mg} / \mathrm{L}$ as $\mathrm{C}$ \\
\hline Suspended sediment & $\mathrm{mg} / \mathrm{L}$ \\
\hline Dissolved solids & $\mathrm{mg} / \mathrm{L}$ \\
\hline Dissolved sodium & $\mathrm{mg} / \mathrm{L}$ as $\mathrm{Na}$ \\
\hline Dissolved chloride & $\mathrm{mg} / \mathrm{L}$ as $\mathrm{Cl}$ \\
\hline Dissolved oxygen & $\mathrm{mg} / \mathrm{L}$ \\
\hline${ }^{1}$ Fraction of dissolved oxygen at saturation & Percent \\
\hline Total phosphorus & $\mathrm{mg} / \mathrm{L}$ as $\mathrm{P}$ \\
\hline${ }^{1}$ Total nitrogen & $\mathrm{mg} / \mathrm{L}$ as $\mathrm{N}$ \\
\hline Total nitrate plus nitrite & $\mathrm{mg} / \mathrm{L}$ as $\mathrm{N}$ \\
\hline Total nitrite & $\mathrm{mg} / \mathrm{L}$ as $\mathrm{N}$ \\
\hline Total ammonia plus organic nitrogen & $\mathrm{mg} / \mathrm{L}$ as $\mathrm{N}$ \\
\hline Total ammonia & $\mathrm{mg} / \mathrm{L}$ as $\mathrm{N}$ \\
\hline Total boron & $\mu \mathrm{g} / \mathrm{L}$ as $\mathrm{B}$ \\
\hline Total lead & $\mu \mathrm{g} / \mathrm{L}$ as $\mathrm{Pb}$ \\
\hline Fecal coliform bacteria & MPN/100 mL \\
\hline
\end{tabular}

1 Values of constituent or property are calculated. 
Water-quality and streamflow data were retrieved from the NWIS data base. Waterquality data for water years 1976-93 are available for 13 stations; partial records are available for the other 6 stations (fig. 7). Streamflow data are available for 13 water-quality stations for water years 1976-93.

\section{Data Preparation}

Water-quality and instantaneous-streamflow data retrieved from the NWIS data base were reviewed extensively for accuracy and maintained in a SAS data base. Values of dissolved nitrate plus nitrite and dissolved nitrite were substituted for values of total nitrate plus nitrite and total nitrite where the latter were missing. This substitution is appropriate because nitrate and nitrite are anions that are poorly absorbed to mineral surfaces and, therefore, are present in ambient water almost exclusively as dissolved species (Hem, 1985). Where both dissolved and total concentration values were available for nitrate plus nitrite and nitrite, little or no difference was observed.

\section{Water-Quality Data}

Values for the fraction of dissolved oxygen at saturation and concentrations of hardness, total organic carbon, and total nitrogen were calculated.

The fraction of dissolved oxygen at saturation is the ratio of the measured dissolvedoxygen concentration to the dissolved-oxygen concentration at saturation, in percent, computed by using the following equation:

where

$$
F D O=100\left[\frac{D O}{D O_{\text {sat }}}\right]
$$

$F D O=$ fraction of dissolved oxygen at saturation;

$D O=$ dissolved-oxygen concentration, in milligrams per liter; and

$D O_{\text {sat }}=$ dissolved-oxygen at saturation, in milligrams per liter.

The following evaluation by Weiss (R.J. Pickering, U.S. Geological Survey, written commun., 1981) was used to calculate the concentration of dissolved oxygen at saturation:

where

$$
\ln D O_{\text {sat }}=A_{1}+A_{2} \frac{100}{T}+A_{3} \ln \frac{T}{100}+A_{4} \frac{T}{100}+S\left[B_{1}+B_{2} \frac{T}{100}+B_{3}\left(\frac{T}{100}\right)^{2}\right],
$$

$$
\begin{aligned}
& \ln \quad=\text { natural logarithm; } \\
& D O_{\text {sat }}=\text { dissolved-oxygen concentration at saturation; } \\
& A_{1} \quad=173.4292 \\
& A_{2} \quad=249.6339 \\
& A_{3} \quad=143.3483 \\
& A_{4} \quad=21.8492
\end{aligned}
$$




$$
\begin{array}{ll}
B_{1} & =0.033096 ; \\
B_{2} & =0.014259 ; \\
B_{3} & =0.001700 ; \\
T & =\text { temperature, in degrees Kelvin; and } \\
S & =\text { salinity, in grams per kilogram. }
\end{array}
$$

The concentration of total hardness, expressed as calcium carbonate in milligrams per liter $\left(\mathrm{mg} / \mathrm{L}\right.$ as $\left.\mathrm{CaCO}_{3}\right)$, was calculated as follows:

$$
\text { Total hardness }=2.497[\mathrm{Ca}]+4.118[\mathrm{Mg}]
$$

where

$\mathrm{Ca}$ is the dissolved-calcium concentration, in milligrams per liter, and

$\mathrm{Mg}$ is the dissolved-magnesium concentration, in milligrams per liter.

Some total organic carbon concentrations were calculated as the sum of the dissolved and particulate organic carbon concentrations; all are expressed as carbon in milligrams per liter ( $\mathrm{mg} / \mathrm{L}$ as $\mathrm{C})$. The concentration of total nitrogen was calculated as the sum of the total nitrate plus nitrite and total ammonia plus organic nitrogen concentrations; all are expressed as nitrogen in milligrams per liter ( $\mathrm{mg} / \mathrm{L}$ as $\mathrm{N})$.

Estimated loads were calculated for each of 16 constituents (no loads were calculated for the fraction of dissolved oxygen at saturation or fecal coliform bacteria) by multiplying the concentration by the instantaneous streamflow and applying unit conversions to yield an instream load in pounds per day (lb/d), as follows:

$$
\begin{gathered}
\text { load }(\mathrm{lb} / \mathrm{d})=\text { concentration }(\mathrm{mg} / \mathrm{L}) \times \text { streamflow }\left(\mathrm{ft}^{3} / \mathrm{s}\right) \times 2.20462 \times 10^{-6} \mathrm{lb} / \mathrm{mg} \\
\times 86,400 \mathrm{~s} / \mathrm{d} \times 28.316 \mathrm{~L}_{\mathrm{ft}^{3}} .
\end{gathered}
$$

When concentrations are in micrograms per liter, the conversion is

$$
\begin{gathered}
\text { load }(\mathrm{lb} / \mathrm{d})=\text { concentration }(\mu \mathrm{g} / \mathrm{L}) \times \text { streamflow }\left(\mathrm{ft}^{3} / \mathrm{s}\right) \times 2.20462 \times 10^{-9} \mathrm{lb} / \mu \mathrm{g} \\
\times 86,400 \mathrm{~s} / \mathrm{d} \times 28.316 \mathrm{~L}_{\mathrm{ft}^{3}} .
\end{gathered}
$$

Steps were taken to ensure consistent data quality because of the long time period over which the data were collected. Water-quality data for the period of record, water years 1976 to 1993, were reviewed to identify any obvious data inconsistencies (that is, data outliers), because of changes in laboratory remark codes, reporting levels, analytical methods, project data-entry protocols, project data-quality review protocols, sample preservation, and sample processing. Many of these factors were known to have changed over the 18-year period of record; this may have affected the quality of the data (in this study, only data outliers were of concern). Breidt and others (1991) reported finding similar water-quality-data anomalies in this period of record. 
This review resulted in the removal from the data base of less than 1 percent of the original data set. Most of the corrections (removal) were for field measurements made prior to 1985 and for data that had been entered into the data base manually from paper records.

No attempt was made to identify data-biasing effects on the median values. The data review was performed prior to statistical analysis and interpretation. Data in the 0.025 and 0.975 percentiles for each station were candidates for being data outliers. In addition, plots of constituent concentrations by month, as well as constituent concentrations as a function of streamflow, were visually inspected for potential outliers. Data were evaluated by month of sample collection to determine whether a value was a seasonal outlier and by discharge to determine whether the value was an outlier because it was affected by dilution during high flow. In addition, changes in laboratory reporting remark codes and censoring limits were reviewed. The analytical method used for the years in which the censored data were collected was determined from tables reported by Friedman and Fishman (1989) and Fishman and others (1994), and the analytical method lower-reporting limit was checked against those reported for that analytical method in Skougstad and others (1979), Fishman and Friedman (1989), and Wershaw and others (1987). The outliers were evaluated by considering:

(1) concentrations of related constituents in the same sample,

(2) the constituent concentration at sites upstream or downstream,

(3) the effects of an early or late change of season,

(4) the number of measurements for the month or season,

(5) the presence of point-source discharges upstream from the sampling site,

(6) the possibility of constituent inputs from seasonal nonpoint-source runoff,

(7) streamflow regulation,

(8) the streamflow discharge, and

(9) surrounding geology and physiographic province.

Outliers were deleted only if no plausible explanation based on the factors listed above was found.

\section{Streamflow Data}

Instantaneous-streamflow values were used when available to calculate instream loads; when those values were not available, an estimated daily mean was used. Continuous streamflow records from gages were available for 13 water-quality stations and were used to determine instantaneous streamflows. For the six stations with no streamflow data, a correlation with an adjacent gaging station was developed, and a mean daily streamflow was estimated from the correlation.

As with the water-quality data, steps were taken to ensure consistent data quality because of the long time period over which the data were collected. Streamflow data for the period of record, water years 1976 to 1993, were reviewed to identify any obvious data inconsistencies (that is, data outliers), many of which were due to data entry errors. The review was performed prior to statistical analysis and interpretation. This review resulted in the removal from the data base of less than 2 percent of the original data set. 
Streamflow data from each surface-water-quality monitoring station were regressed on daily mean values from the NWIS data base to ensure that the values were consistent. Residuals of plots of streamflow as a function of gage height, and streamflow at adjacent or nearby continuous-record stations, were evaluated. Outliers were identified as those values with studentized residuals larger than an absolute value of 2 and were further evaluated by considering:

(1) the time of sample collection,

(2) upstream flow regulation, and

(3) streamflow at nearby stations.

If no plausible explanation for the apparent inconsistency of a data point (an outlier), based on the factors listed above, was found, the daily mean values were used. These new values were double-checked by plotting them on a graph of field specific conductance as a function of flow duration. Specific conductance would be expected to be inversely proportional to streamflow, except during times of snow melt. The measurement of specific conductance is independent of the measurement of streamflow.

\section{Flow-Duration Data}

Flow durations for each water-quality station were obtained as data from WATSTORE (National Water Data Storage and Retrieval System), as output from computer simulations using MOVE.1 (Maintenance of Variance Extension, Type 1) (Hirsch, 1982), and as drainage area adjustments from nearby surface-water gaging stations (table 3 ).

Flow-duration tables were developed by using the Daily Value Statistics (DVSTAT) computer program in the WATSTORE data base for 13 of the 19 surface-water-quality stations that had continuous streamflow records. Flow-duration data show the percentage of time that a particular discharge is exceeded, and a flow-duration point is a discharge value, in $\mathrm{ft}^{3} / \mathrm{s}$, interpolated from a duration table for a particular percentage of time. For the purpose of this study, the 25-percent duration point was used to determine high-flow conditions, and the 75percent duration point was used to determine the low-flow conditions. The resulting values for each surface-water-quality station are shown in table 3.

Base-flow relations were determined for 4 of the 19 water-quality gaging stations by correlating instantaneous low-flow discharge at the partial-record station with the mean daily discharge at a nearby "index" continuous-record gaging station. A streamflow record extension technique, MOVE.1, was used to develop the correlations (Hirsch, 1982). MOVE.1 was used because it was adequate for the purposes of this study, in which flow duration was used only to divide streamflow data into groups of high, moderate, and low ranges for trend analysis. The relations are made in the following form:

$$
L Q_{P R}=u_{P R}+\left(\frac{S_{P R}}{S_{C R}}\right)\left[L Q_{C R}-u_{C R}\right]
$$

where

$$
L Q_{P R}=\text { the base-10 logarithm of the partial-record streamflow, }
$$


Table 3. Estimated flow-duration values of mean daily discharge and data source for surfacewater-quality stations in the Hackensack, Passaic, Elizabeth, and Rahway River Basins, N.J. $\left[\mathrm{ft}^{3} / \mathrm{s}\right.$, cubic feet per second; \%, percent; WATSTORE, National Water Data Storage and Retrieval System; MOVE.1, Maintenance of Variance Extension, Type 1; Drainage Area, adjusted on basis of drainage area from nearby surface-water gages]

\begin{tabular}{|c|c|c|c|}
\hline \multirow[b]{2}{*}{ Station number } & \multicolumn{2}{|c|}{$\begin{array}{l}\text { Flow duration values of mean daily discharge, } \\
\qquad \text { in } \mathrm{ft}^{3} / \mathrm{s}\end{array}$} & \multirow[b]{2}{*}{ Source } \\
\hline & $25 \%$ & $75 \%$ & \\
\hline 01377000 & 107 & 35.2 & WATSTORE \\
\hline 01379000 & 112 & 19.2 & WATSTORE \\
\hline 01379500 & 211 & 34.5 & WATSTORE \\
\hline 01380500 & 298 & 78.7 & WATSTORE \\
\hline 01381200 & 190 & 26.0 & MOVE. 1 \\
\hline 01381500 & 62.7 & 22.1 & WATSTORE \\
\hline 01381800 & 109 & 42.7 & MOVE. 1 \\
\hline 01382000 & 823 & 182 & MOVE. 1 \\
\hline 01382500 & 37.6 & 0.0 & WATSTORE \\
\hline 01387500 & 280 & 58.4 & WATSTORE \\
\hline 01388000 & 357 & 71.0 & WATSTORE \\
\hline 01388600 & 559 & 125 & Drainage Area \\
\hline 01389005 & 1,500 & 331 & Drainage Area \\
\hline 01389500 & 1,570 & 249 & WATSTORE \\
\hline 01389880 & 1,720 & 265 & MOVE.1 \\
\hline 01391500 & 119 & 41.8 & WATSTORE \\
\hline 01393450 & 20.7 & 7.9 & WATSTORE \\
\hline 01394500 & 23.6 & 5.6 & WATSTORE \\
\hline 01395000 & 41.7 & 8.2 & WATSTORE \\
\hline
\end{tabular}


$u_{P R} \quad=$ the mean of the logarithms of partial-record streamflow,

$S_{P R} \quad=$ the standard deviation of logarithms of partial-record streamflow,

$L Q_{C R}=$ the base-10 logarithm of the index continuous-record streamflow,

$u_{C R} \quad=$ the mean of the logarithms of the index continuous-record streamflows, and

$S_{C R} \quad=$ the standard deviation of logarithms of the index continuous-record streamflow.

The flow-duration values for partial-record stations 01388600, Pompton River at Packanack Lake, and 01389005, Passaic River below Pompton River at Two Bridges, were estimated using drainage-area adjustments from nearby surface-water gaging stations (table 3 ).

\section{$\underline{\text { Statistical Methods }}$}

Concentration measurements were selected only if they had an associated, nonzero value of streamflow (instantaneous or estimated); only one observation per constituent per day was used. Concentration values were reported as "uncensored," "less-than," and "greater-than". Concentrations of constituents other than fecal coliform bacteria were either uncensored or lessthan values; some measurements of fecal coliform bacteria were greater-than values.

Median concentrations and relations of surface-water quality to streamflow were determined for each constituent and station. The following types of relations of surface-water quality to streamflow are presented graphically by constituent for each station in appendixes 1-18: concentration to streamflow, load to streamflow, and trends in concentrations during low and high flows.

\section{Calculation of Medians}

Medians were calculated for measurements made during two periods - the entire period of study (water years 1976-93) and the last 5 years of the period of study (water years 1989-93). The method of calculation depended upon whether the data set contained censored values. For data sets with only uncensored data, the values were ranked and the median was calculated as the 50th percentile. For data sets with less-than values but no greater-than values, medians were calculated by using the adjusted maximum likelihood method described in Cohn (1988) and Helsel and Cohn (1988). If the data set contained either an insufficient number of observations for this method or greater-than values, the median was determined by manually ranking and identifying the 50th percentile value.

\section{Determination of Relations of Surface-Water Quality to Streamflow}

The processes used to determine relations between concentration and streamflow and load and streamflow, and trends in concentrations during high and low flows are described in this section. 


\section{$\underline{\text { Relations of concentration to streamflow }}$}

Water quality is strongly influenced by biological activity, which is seasonal; therefore, relations between concentration and streamflow were developed by using (1) all measurements, (2) growing-season measurements only, and (3) nongrowing-season measurements only. The growing season in New Jersey is from April 1 through October 31; the nongrowing season is from November 1 through March 31. The dates for the growing and nongrowing seasons were based on the average times of the first and final frosts in New Jersey (Ruffner and Bair, 1977). All relations take the following form:

$$
\log (C O N C)=S L O P E \times \log (F L O W)+I N T,
$$

where

$$
\begin{aligned}
& \log =\text { base-10 logarithm; } \\
& \text { CONC }=\text { constituent concentration, in indicated units; } \\
& \text { SLOPE = the slope of the relation; } \\
& \text { FLOW = streamflow, in cubic feet per second; and } \\
& I N T \quad=\text { the intercept of the relation. }
\end{aligned}
$$

These relations were developed by using Tobit regression (Cohn, 1988), which includes less-than values. For Tobit regression in this report, greater-than values were considered to be uncensored. Where there were no less-than values, this method resulted in the same values of SLOPE and INT as those calculated by ordinary least-squares regression. A goodness-of-fit value such as the correlation coefficient is not presented; the Tobit method does not result in such a value.

A relation of water quality to streamflow was developed only if there were at least nine uncensored concentrations. T.A. Cohn (U.S. Geological Survey, written commun., 1995) noted that at least nine uncensored values were needed to use the Tobit method with two unknowns. Nine uncensored values were sometimes insufficient data from which to calculate statistically significant results.

A relation using all measurements is reported only if the value of SLOPE was different from zero at the 0.05 level of significance; otherwise, a SLOPE of " 0 " is reported. A "not determined" value of SLOPE is reported if the data were insufficient to conduct the analysis. A value of INT was calculated only if the value of SLOPE was different from zero.

Each set of seasonal relations was developed and reported by using the methods just described if an analysis of covariance (described below) indicated that the seasonal relations were different from one another at the 0.05 level of significance. The analysis of covariance was conducted only if there were at least nine uncensored measurements during each season. 
The analysis of covariance followed the approach in Helsel and Hirsch (1992), except that Tobit regression was used in place of ordinary least-squares regression. The analysis determined whether a complex model with a seasonal component was significantly better than a simple model without a seasonal component. The simple model is given in equation (7); the complex model is given in equation (8).

$$
\log (C O N C)=\left[S L O P E_{1} \times \log (F L O W)+I N T_{1}\right]+\left[S L O P E_{2} \times \log (F L O W)+I N T_{2} \times I\right]
$$

where

$$
\begin{aligned}
& \log \quad=\text { base-10 logarithm; } \\
& \text { CONC = constituent concentration, in indicated units; } \\
& \text { FLOW = streamflow, in cubic feet per second; } \\
& I \quad=\text { an index for season }(\mathrm{I}=0 \text { for the nongrowing season, and } \mathrm{I}=1 \text { for the growing } \\
& \text { season); } \\
& S L O P E_{1}=\text { the slope for the nongrowing season; } \\
& I N T_{1} \quad=\text { the intercept for the nongrowing season; } \\
& S L O P E_{2}=\text { the difference between the growing- and nongrowing-season slopes; and } \\
& I N T_{2}=\text { the difference between the growing- and nongrowing-season intercepts. }
\end{aligned}
$$

A test statistic different from that used by Helsel and Hirsch (1992) was calculated because of the use of Tobit regression in the analysis of covariance (T.A. Cohn, written commun., 1995). The value, $X$, was determined from the results of the simple and complex models, then compared to the value of the chi-square distribution with 2 degrees of freedom and a 0.05 level of significance. If the value of $\mathrm{X}$ equalled or exceeded the corresponding value of chi-square distribution, the seasonal relations differed from one another in SLOPE or INT or both. Whether SLOPE was different or INT was different was not determined. The value of X was calculated as follows:

$$
X=-2 \times \ln \left[\left(L K H D_{S}\right) /\left(L K H D_{C}\right)\right],
$$

where

$$
\begin{aligned}
& X \quad=\text { the test statistic, } \\
& \ln \quad=\text { natural logarithm, } \\
& L K H D_{S}=\text { the likelihood of the simple relation, and } \\
& L K H D_{C}=\text { the likelihood of the complex relation. }
\end{aligned}
$$


The detection level of each constituent at each station is required to conduct Tobit regression. The detection limits for constituents with only uncensored values were determined by considering the method of analysis and the smallest concentration measured at all stations. These values (table 4) are either equal to the smallest less-than value or slightly less than the smallest uncensored value measured at all stations during water years 1976-93.

\section{Relations of load to streamflow}

The relation of load to streamflow was developed by using the same procedures as those used to develop the relation of concentration to streamflow for all measurements. Loads were not determined for fraction of dissolved oxygen at saturation and fecal coliform bacteria. For each constituent and station, the detection limit was set equal to the smallest uncensored load measured at the station. The load relation takes the following form:

$$
\log (L O A D)=S L O P E \times \log (F L O W)+I N T,
$$

where

$$
\begin{aligned}
& \log \quad=\text { base-10 logarithm; } \\
& \angle O A D=\text { constituent load, in pounds per day; } \\
& S L O P E=\text { the slope of the relation; } \\
& \text { FLOW }=\text { streamflow, in cubic feet per second; and } \\
& I N T \quad=\text { the intercept of the relation. }
\end{aligned}
$$

A smoothed relation of load to streamflow is shown for a constituent at each station at which there are 10 or more values. This relation was determined by using the SM smoothing routine in SAS (SAS Institute, Inc., 1990, p. 416).

\section{Trends in concentrations during low and high flows}

Trends in concentrations during low and high flows were tested to determine whether the probability distribution from which the observations come increased or decreased during water years 1976-93. The 75 and 25 percent values of the flow durations were used to divide the measurements for each station into a low- or high-flow group, respectively. Concentrations during low flows were designated as those measured at streamflows less than or equal to the daily mean streamflow that was exceeded 75 percent of the time; concentrations during high flows were designated as those measured at streamflows greater than the daily mean streamflow that was exceeded 25 percent of the time. 
Table 4. Estimated detection limits for selected constituents measured in the Hackensack, Passaic, Elizabeth, and Rahway River Basins, N.J., water years 1976-93

[mg/L, milligrams per liter; $\mathrm{CaCO}_{3}$, calcium carbonate; $\mathrm{C}$, carbon; $\mathrm{Na}$, sodium; $\mathrm{Cl}$, chloride; $\%$, percent; $\mathrm{P}$, phosphorus; $\mathrm{N}$, nitrogen; $\mu \mathrm{g} / \mathrm{L}$, micrograms per liter; $\mathrm{B}$, boron; $\mathrm{Pb}$, lead;

MPN/100 mL, most probable number per 100 milliliters.]

\begin{tabular}{|c|c|}
\hline Constituent & $\begin{array}{l}\text { Estimated } \\
\text { detection } \\
\text { limit }\end{array}$ \\
\hline Alkalinity, $\mathrm{mg} / \mathrm{L}$ as $\mathrm{CaCO}_{3}$ & 1 \\
\hline Hardness, $\mathrm{mg} / \mathrm{L}$ as $\mathrm{CaCO}_{3}$ & 10 \\
\hline Total organic carbon, $\mathrm{mg} / \mathrm{L}$ as $\mathrm{C}$ & .2 \\
\hline Suspended sediment, $\mathrm{mg} / \mathrm{L}$ & 1 \\
\hline Dissolved solids, $\mathrm{mg} / \mathrm{L}$ & 10 \\
\hline Dissolved sodium, $\mathrm{mg} / \mathrm{L}$ as $\mathrm{Na}$ & 1 \\
\hline Dissolved chloride, $\mathrm{mg} / \mathrm{L}$ as $\mathrm{Cl}$ & 1 \\
\hline Dissolved oxygen, $\mathrm{mg} / \mathrm{L}$ & .5 \\
\hline Fraction of dissolved oxygen at saturation, $\%$ & 5 \\
\hline Total phosphorus, $\mathrm{mg} / \mathrm{L}$ as $\mathrm{P}$ & .01 \\
\hline Total nitrogen, $\mathrm{mg} / \mathrm{L}$ as $\mathrm{N}$ & .1 \\
\hline Total nitrate plus nitrite, $\mathrm{mg} / \mathrm{L}$ as $\mathrm{N}$ & .05 \\
\hline Total nitrite, $\mathrm{mg} / \mathrm{L}$ as $\mathrm{N}$ & .002 \\
\hline Total ammonia plus total organic nitrogen, $\mathrm{mg} / \mathrm{L}$ as $\mathrm{N}$ & .03 \\
\hline Total ammonia, $\mathrm{mg} / \mathrm{L}$ as $\mathrm{N}$ & .01 \\
\hline Total boron, $\mu \mathrm{g} / \mathrm{L}$ as $\mathrm{B}$ & 10 \\
\hline Total lead, $\mu \mathrm{g} / \mathrm{L}$ as $\mathrm{Pb}$ & 1 \\
\hline Fecal coliform bacteria, MPN/100 mL & 2 \\
\hline
\end{tabular}


For both the low- and high-flow data sets, trend tests were conducted only if there was at least one measurement in each data set consisting of not less than four of the six water years in each one-third of the period of study (18 years). This requirement followed a recommendation made in Helsel and Hirsch (1992) that there be no less than 20 percent of the total measurements in each one-third of the period being tested for trends. Therefore, 12 is the minimum number of low- or high-flow measurements used in a test. Fewer data could have been tested for trends. The fewer the data, however, the less likely it is that the measured concentrations represent conditions during the period tested and, therefore, the less likely that the results of the trend test are accurate.

The seasonal Kendall's tau method (Hirsch and others, 1982) was used to examine the data for trends. For both the low- and high-flow data sets, the test was run on the median of the measured concentrations for each water year because of variations in sampling frequency (Hirsch and others, 1982). The test statistic, tau, was calculated from the relative sizes of the annual median concentrations, then tested to see whether it was significantly different from zero. For this report, a trend is indicated if the value of tau was significantly different from zero at the 0.05 level. Seasonality was not included in the test.

A value of SLOPE is reported for constituent concentrations during either low or high flows if a trend was indicated. The value of SLOPE is the median of the slopes of all pairs of annual median concentrations. A SLOPE value of " 0 " is reported if sufficient data were available for a trend test, but a trend was not indicated; a "not determined" value is reported if there were insufficient data for a test. The units of SLOPE are units of concentration per year.

No value is reported for the intercept of the relation showing the trend of concentration over time. An intercept value is calculated by the trend test only for the purpose of showing the trend in a plot.

Multiple trend tests were conducted on data sets with censored values; the censored values were set at their minimum and maximum possible values. Two tests were conducted on data sets with less-than values but no greater-than values - one with the less-than values set to the reporting limit and one with the less-than values set to zero. Two tests were conducted on data sets with greater-than values but no less-than values - one with the greater-than values set to the reporting limit and one with the greater-than values set to $10^{7}$ (a value greater than all reported uncensored values). Four tests were conducted on data sets with both less-than and greater-than values-one with each of the permutations of the greater-than and less-than values discussed above.

For each data set with censored values, the results are reported only for the trend relation with the least significant value for tau. Because of the uncertainty of the censored data, a significant trend slope is reported only if a slope is determined when the censored data are set equal to both their minimum and maximum values.

\section{RELATIONS OF SURFACE-WATER QUALITY TO STREAMFLOW}

An understanding of the relation of surface-water quality to streamflow is important for assessment of the relative contributions of point sources, ground water, and storm runoff to instream loads. Point sources (permitted discharges) release constituents to a stream at a 
relatively constant rate, independent of the receiving streamflow conditions. Ground-water contributions to a stream are somewhat constant, varying slightly with season and precipitation rate. Storm-runoff contributions to a stream are intermittent, depending on storm intensity and frequency, and occur only during high flows. Instream constituent concentrations are a summation of the contributions from these constant (point source and ground water) and intermittent (storm runoff) sources.

To describe the relation of surface-water quality to streamflow, the data analyses are presented in three ways. First, three aspects of the relation of surface-water quality to streamflow (concentration to streamflow, load to streamflow, and trends in concentrations during low and high flows) are presented graphically by constituent for each station in appendixes 1-18. Second, the data analyses are presented by basin in the text; tables for each station list the median concentrations, the regression slopes of concentration and load to streamflow, and the directions of the trends in concentrations during low and high flows for all constituents along with the AMNET impairment status at and near the station. Third, relations are presented in schematics showing the regional trends in concentrations during low and high flows and the slopes of load to streamflow by constituent.

Appendixes 1-18 illustrate the relations of surface-water quality to streamflow by constituent for each station with three graphs. Figure 8 is an example page from appendix 14 . The first graph shows the relation of concentration to streamflow. Plots of concentration to streamflow indicate how instream constituent concentrations vary with streamflow, but do not indicate the relative contributions of constant and intermittent sources. Data for stations on streams that drain developed areas show greater scatter, especially for inorganic constituents such as sodium, chloride, and hardness. Relations between concentration and streamflow were developed by using (1) all measurements, (2) only measurements collected during the growing season, and (3) only measurements collected during the nongrowing season. Growing-season measurements are shown with open symbols, and nongrowing-season measurements are shown with crisscrossed symbols. Different symbols are used to show uncensored and censored values. For each group of measurements, the number of observations and values of slope and intercept are listed, and a regression line is shown when the slope of concentration to streamflow is different from zero at the 0.05 significance level. A seasonal dependency is indicated when the relations of concentration to streamflow for the growing- and nongrowing-season measurements are different. The 75 and 25 percentiles of the flow duration also are indicated. 


\section{APPENDIX 14. RELATIONS OF CONSTITUENT TO STREAMFLOW: TOTAL AMMONIA PLUS ORGANIC NITROGEN 01389500 PASSAIC RIVER AT LITTLE FALLS, N.J.}

[NVALUES, NUMBER OF VALUES; LOG, BASE-10 LOGARITHM; CONC, CONCENTRATION IN INDICATED UNITS; INT, INTERCEPT; FLOW, STREAMFLOW IN CUBIC FEET PER SECOND; NWYS, NUMBER OF WATER YEARS DURING WHICH AT LEAST ONE MEASUREMENT WAS MADE; A SLOPE VALUE OF ' 0 ' INDICATES THAT THE SLOPE IS NOT SIGNIFICANTLY DIFFERENT FROM ZERO; ND, NOT DETERMINED; CaCO3, CALCIUM CARBONATE; C, CARBON; N, NITROGEN; P, PHOSPHORUS; Pb, LEAD; B, BORON; Cl, CHLORIDE; Na, SODIUM; MOST PROBABLE NUMBER INDEX IS PER 100 MILLILITERS]

\section{RELATION OF CONCENTRATION TO STREAMFLOW}

GROWING SEASON CONCENTRATION

$\begin{array}{ccc}\bigcirc & \text { UNCENSORED VALUE } & \oplus \\ \nabla & \text { 'LESS - THAN' VALUE } & \forall \\ \triangle & \text { 'GREATER -THAN' VALUE } & \nexists\end{array}$

RELATION: LOG(CONC) = SLOPE*LOG(FLOW) + INT

ALL VALUES

\begin{tabular}{llr} 
NVALUES & SLOPE & INT \\
\hline 156 & -0.3 & 0.93
\end{tabular}

[SEASONAL RELATIONS DETERMINED;

THEY ARE DIFFERENT FROM ONE ANOTHER]

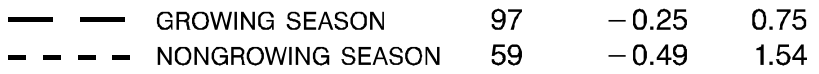

STREAMFLOW EXCEEDED INDICATED PERCENTAGE OF TIME

- - 75 PERCENT - - - 25 PERCENT

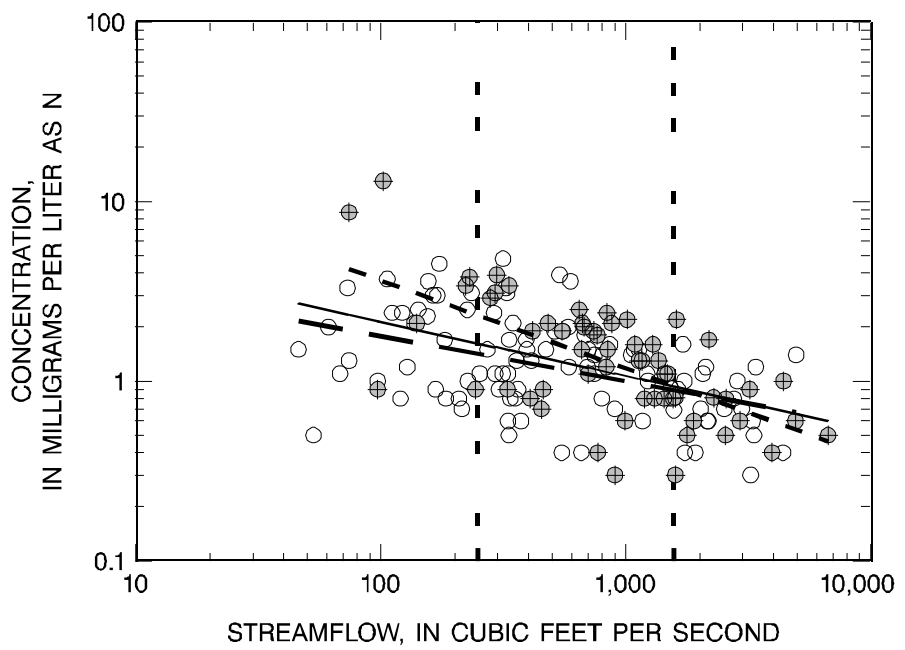

RELATION OF LOAD TO STREAMFLOW

\begin{tabular}{ll}
\multicolumn{2}{c}{ LOAD } \\
\hline$\times$ & UNCENSORED VALUE \\
$\nabla$ & 'LESS - THAN' VALUE
\end{tabular}

RELATION: LOG(LOAD) = SLOPE*LOG(FLOW) + INT

\begin{tabular}{|c|c|c|}
\hline VALUES & NVALUES & SLOPE \\
\hline VALU & 156 & 0.7 \\
\hline
\end{tabular}

SMOOTHED RELATION BETWEEN LOAD AND FLOW (SHOWN IF THERE ARE 10 OR MORE VALUES)

STREAMFLOW EXCEEDED INDICATED PERCENTAGE OF TIME

- - 75 PERCENT - - - 25 PERCENT

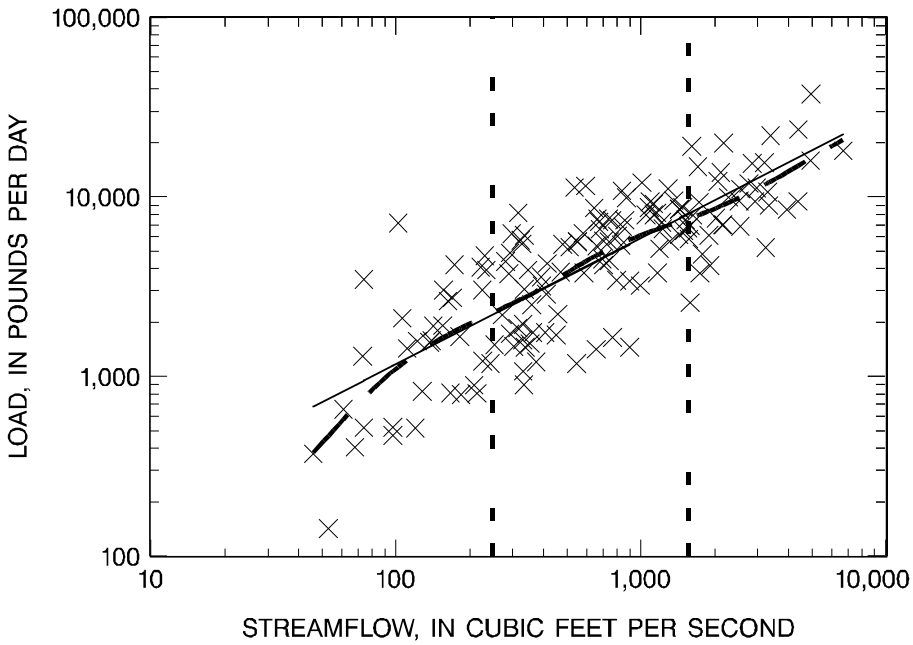

STREAMFLOW, IN CUBIC FEET PER SECOND

TRENDS IN LOW - AND HIGH-FLOW CONCENTRATIONS

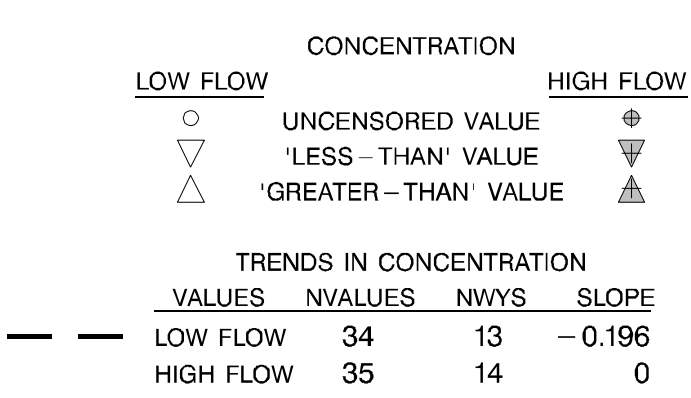

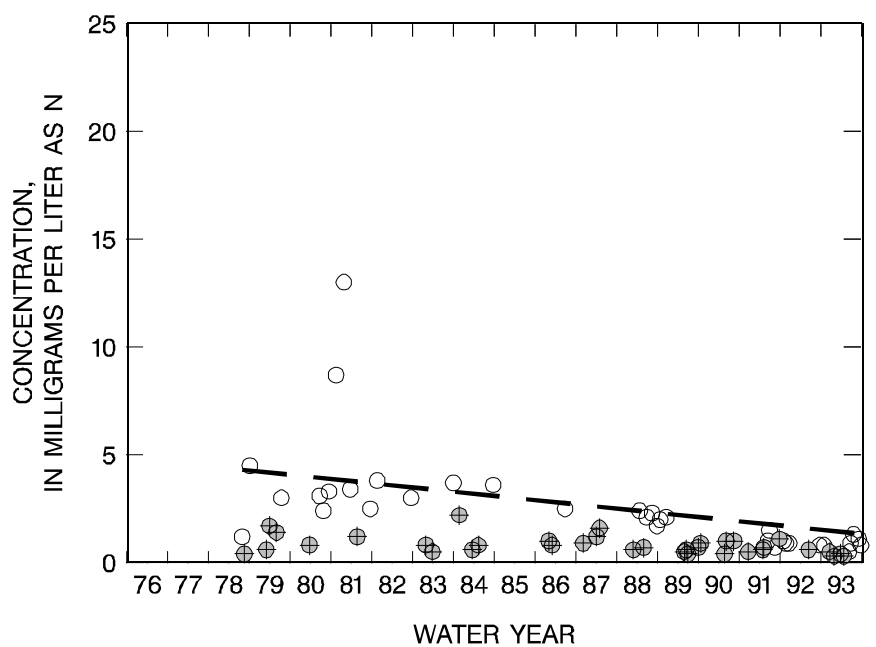

Figure 8. Example page from Appendix 14 of graphs showing relation of concentration to streamflow, relation of load to streamflow, and trends in low- and high-flow concentrations for total ammonia plus organic nitrogen at a station on the Passaic River at Little Falls, New Jersey, for water years 1976-93. 
The second graph in figure 8 shows the relation of load to streamflow. The regression slope of load to streamflow indicates the relative contributions of constant and intermittent sources to the instream load. The steeper the slope, the greater the contribution during increased streamflow from storm runoff (intermittent sources). Relations between load and streamflow were developed using all measurements. Different symbols are used to show uncensored and censored values. The number of observations and values of slope and intercept are shown, and a regression line is drawn when the slope is different from zero at the 0.05 significance level. A smoothed relation between load and streamflow is shown when there are 10 or more observations. The 75 and 25 percentiles of the flow duration also are indicated.

The third graph in figure 8 shows the trends in concentrations during low and high flows. Trends in constituent concentrations during high and low flows can indicate changes over time in the contributions from intermittent and constant sources, respectively. Positive trends during high flows indicate an increase in the storm runoff contributions over time, whereas negative trends indicate a decrease in the storm runoff contributions. Positive trends during low flows indicate an increase in the contributions from point sources and ground water over time, whereas negative trends indicate a decrease in the contributions from point sources and ground water.

Measurements during low flows are shown with open symbols, and measurements during high flows are shown with crisscrossed symbols. Different symbols are used to show uncensored and censored values. The numbers of observations and water years during which at least one measurement was made are shown for each group of measurements. Trends are indicated by regression lines and slope values when the seasonal Kendall tau value is significant.

\section{Analysis of Relations by Basin}

Median concentrations, regression slopes of concentration and load to streamflow, and directions of the trends in concentrations during low and high flows for each constituent are presented in tables 5 through 23. Constituents that show a seasonal dependency (the relations of concentration to streamflow for the growing and nongrowing seasons are different) and the 1993 AMNET impairment status in the vicinity (at and within five miles upstream and downstream) of the surface-water-quality station also are listed. Median concentrations were calculated for two periods, the entire period of study (water years 1976-93) and the last five years of the period of study (water years 1989-93) to provide a visual comparison of water quality to the AMNET impairment status. In tables 5 through 23, the direction of trends in concentrations during low and high flows are represented by,,+- 0 , and NA symbols. Results of statistical tests are discussed for each river basin. One- to four-letter abbreviations are used for each water-quality constituent throughout the discussion. (See Conversions Factors and Abbreviated Water-Quality Units, p. x.)

Slopes of load to streamflow for each constituent are divided into three ranges in order to describe the relative contributions of constant (point source and ground water) and intermittent (storm runoff) sources to instream load. High-range slopes are greater than or equal to 75 percent of the interval between the minimum and maximum slopes. For stations with slopes in the high range, a larger contribution from storm runoff to instream load occurs than at other sites, suggesting an increased relative importance of nonpoint sources at these sites. Moderate-range slopes are greater than 25 percent and less than 75 percent of the interval between the minimum and maximum slopes. Low-range slopes are less than or equal to 25 percent of the interval 
between the minimum and maximum slopes. For stations with slopes in the low range, a smaller contribution from storm runoff to instream load occurs than at other sites, suggesting an increased relative importance of continuous sources at these sites. For constituents with large slopes of load to streamflow (greater than 0.8 ), however, storm runoff is most likely the more significant contributor to instream loads, even for stations with load slopes in the low range.

In 1992, the Bureau of Water Monitoring of the NJDEP reactivated the AMNET to monitor benthic-macroinvertebrate populations at 457 stations in the major drainage basins in New Jersey. The objective of this biomonitoring program is to provide long-term, basin-wide, biological data for surface water (New Jersey Department of Environmental Protection, 1994). Stations will be monitored every 5 to 6 years, a realistic temporal lag between the cessation and recovery of a biological community from a perturbation. Biomonitoring uses instream populations of benthic macroinvertebrates as indicators of the quality of the surface water. Species of the instream macroinvertebrate community occupy distinct niches based on their tolerance to environmental conditions; these communities can change as environmental conditions change. Benthic-community biological impairment is indicated by (1) the absence of contaminant-sensitive macroinvertebrate taxa, (2) excessive dominance by certain taxon, (3) low overall taxa richness, or (4) perceptible shifts in community structure relative to a reference condition.

The NJDEP sampling techniques and biometric assessments were modified from U.S. Environmental Protection Agency protocols to integrate community, population, and functional parameters into one easily understood evaluation of biological integrity (New Jersey Department of Environmental Protection, 1994). The integrated assessment results at each station were given an AMNET impairment status rating of non-impaired-the benthic community is comparable to communities found in other undisturbed streams within the region and is characterized by a maximum taxa richness, balanced taxa groups, and good representation of intolerant individuals; moderately impaired - the macroinvertebrate richness and community balance are reduced and intolerant taxa are absent because of taxa composition changes; or severely impaired — the benthic community has dramatically changed and macroinvertebrates are dominated by a few tolerant taxa. When used together with chemical and physical monitoring, benthic macroinvertebrate monitoring is a good indicator of stream quality and possible sources of impairment.

\section{Hackensack River}

Station 01377000 at Riverdale is the only surface-water-quality station on the Hackensack River. The 5-year and period-of-record medians are similar for all constituents (table 5a). The regression slopes of concentration to streamflow for 10 constituents-SS, NA, CL, DO, FDO, TP, TN, NO32, NO2, and BACT - show seasonal dependency. The regression slope of PB load to streamflow is smaller at this station than at all other stations in the study area. The slopes of load to streamflow for all constituents fall within the moderate to high range, indicating a moderate to high contribution of these constituents from surface runoff relative to that at other sites. Insufficient data are available for all constituents at this station to determine trends in concentrations during low and high flows. The AMNET impairment status at station 01377000 is moderately impaired; no other AMNET stations are near this station (table 5b). 
Table 5a. Median concentrations, relations of concentration and load to streamflow, and directions of concentration trends for selected waterquality constituents at water-quality station 01377000, Hackensack River at Riverdale, N.J.

[Number in parenthesis is the number of available data; WY, water years; mg/L, milligrams per liter; $\mathrm{CaCO}_{3}$, calcium carbonate; $\mathrm{C}$, carbon; $\mathrm{Na}$, sodium; Cl, chloride; \%, percent; $\mathrm{P}$, phosphorus; $\mathrm{N}$, nitrogen; $\mu \mathrm{g} / \mathrm{L}$, micrograms per liter; $\mathrm{B}$, boron; $\mathrm{Pb}$, lead; MPN/100 mL, most probable number per 100 milliliters. Regression slopes and trend directions are zero when the slope is not different from zero at the 0.05 significance level; * indicates seasonal dependency (the slope and (or) intercept of growing (April through October) and non-growing (November through March) season data were different at the 0.05 significance level). +, positive trend direction; -, negative trend direction; NA, insufficient data for analysis; ND, undetermined value]

\begin{tabular}{|c|c|c|c|c|c|c|c|c|c|}
\hline \multirow{3}{*}{$\begin{array}{c}\text { Constituent } \\
\text { Alkalinity, } \mathrm{mg} / \mathrm{L} \text { as } \mathrm{CaCO}_{3}\end{array}$} & \multicolumn{2}{|c|}{ 1989-93 WY } & \multicolumn{7}{|c|}{ 1976-93 WY } \\
\hline & \multicolumn{2}{|c|}{$\begin{array}{c}\text { Median } \\
\text { concentration }\end{array}$} & \multicolumn{2}{|c|}{$\begin{array}{c}\text { Median } \\
\text { concentration }\end{array}$} & \multicolumn{2}{|c|}{$\begin{array}{l}\text { Regression } \\
\text { slope of } \\
\text { concentration to } \\
\text { streamflow }\end{array}$} & \multirow{2}{*}{$\begin{array}{c}\begin{array}{c}\text { Regression } \\
\text { slope of } \\
\text { load to } \\
\text { streamflow }\end{array} \\
0.891\end{array}$} & \multirow{2}{*}{$\begin{array}{c}\text { Low- } \\
\text { flow } \\
\text { trend } \\
\text { direction } \\
\text { NA }\end{array}$} & \multirow{2}{*}{$\begin{array}{c}\text { High- } \\
\text { flow } \\
\text { trend } \\
\text { direction } \\
\text { NA }\end{array}$} \\
\hline & 81 & $(26)$ & 79 & (73) & -0.109 & & & & \\
\hline Total hardness, $\mathrm{mg} / \mathrm{L}$ as $\mathrm{CaCO}_{3}$ & 110 & $(27)$ & 100 & $(111)$ & -.138 & & .862 & NA & NA \\
\hline Total organic carbon, $\mathrm{mg} / \mathrm{L}$ as $\mathrm{C}$ & 5.8 & $(25)$ & 5.9 & $(106)$ & 0 & & 1.016 & NA & NA \\
\hline Suspended sediment, mg/L & 12 & (9) & 14 & (24) & 0 & $*$ & 1.399 & NA & NA \\
\hline Dissolved solids, $\mathrm{mg} / \mathrm{L}$ & 230 & $(25)$ & 201 & $(106)$ & -.062 & & .938 & NA & NA \\
\hline Dissolved sodium, $\mathrm{mg} / \mathrm{L}$ as $\mathrm{Na}$ & 34 & $(27)$ & 27 & $(111)$ & 0 & $*$ & .974 & NA & NA \\
\hline Dissolved chloride, $\mathrm{mg} / \mathrm{L}$ as $\mathrm{Cl}$ & 60 & (26) & 45 & $(110)$ & 0 & * & .950 & NA & NA \\
\hline Dissolved oxygen, mg/L & 9.9 & (26) & 8.6 & $(108)$ & 0 & $*$ & 1.050 & NA & NA \\
\hline $\begin{array}{l}\text { Fraction of dissolved oxygen at } \\
\text { saturation, } \%\end{array}$ & 90 & $(25)$ & 89 & $(106)$ & .036 & $*$ & ND & NA & NA \\
\hline Total phosphorus, $\mathrm{mg} / \mathrm{L}$ as $\mathrm{P}$ & .05 & $(27)$ & .06 & $(107)$ & 0 & $*$ & 1.031 & NA & NA \\
\hline Total nitrogen, $\mathrm{mg} / \mathrm{L}$ as $\mathrm{N}$ & 1.2 & $(26)$ & 1.4 & $(92)$ & -.078 & $*$ & .922 & NA & NA \\
\hline Total nitrate plus nitrite, $\mathrm{mg} / \mathrm{L}$ as $\mathrm{N}$ & .52 & $(26)$ & .55 & $(95)$ & -.237 & $*$ & .763 & NA & NA \\
\hline Total nitrite, $\mathrm{mg} / \mathrm{L}$ as $\mathrm{N}$ & .017 & $(25)$ & .018 & (77) & 0 & $*$ & .854 & NA & NA \\
\hline $\begin{array}{l}\text { Total ammonia plus organic nitrogen, } \\
\mathrm{mg} / \mathrm{L} \text { as } \mathrm{N}\end{array}$ & .72 & $(27)$ & .86 & $(107)$ & 0 & & 1.015 & NA & NA \\
\hline Total ammonia, $\mathrm{mg} / \mathrm{L}$ as $\mathrm{N}$ & .10 & $(27)$ & .12 & (97) & 0 & & .804 & NA & NA \\
\hline Total boron, $\mu \mathrm{g} / \mathrm{L}$ as $\mathrm{B}$ & 50 & (4) & 50 & (19) & 0 & & .854 & NA & NA \\
\hline Total lead, $\mu \mathrm{g} / \mathrm{L}$ as $\mathrm{Pb}$ & 2 & (4) & 4 & $(22)$ & 0 & & .861 & NA & NA \\
\hline Fecal coliform bacteria, MPN/100 ml & 160 & $(24)$ & 200 & $(103)$ & 0 & $*$ & ND & NA & NA \\
\hline
\end{tabular}

Table 5b. 1993 AMNET impairment status in the vicinity of water-quality station 01377000, Hackensack River at Riverdale, N.J.

[AMNET, Ambient Biomonitoring Network; WQ, water-quality. Upstream from WQ station is within 5 miles upstream from the WQ station; at WQ-station location is within 0.5 mile upstream or downstream from the WQ station; downstream from WQ station is within 5 miles downstream from the WQ station; ND, undetermined impairment status]

\begin{tabular}{lccc}
\hline & Upstream from WQ station & At WQ-station location & Downstream from WQ station \\
\hline AMNET station & None & AN0205 & None \\
Impairment status & ND & Moderately impaired & ND \\
\hline
\end{tabular}




\section{Passaic River}

Fifteen water-quality stations (tables $6 \mathrm{a}$ and $\mathrm{b}$ through $20 \mathrm{a}$ and $\mathrm{b}$ ) are located in the Passaic River Basin. These stations are located on the upper Passaic, Rockaway, Whippany, Pequannock, Ramapo, Pompton, lower Passaic, and Saddle Rivers.

\section{Upper Passaic River}

Three water-quality stations are located on the upper Passaic River-stations 01379000 near Millington, 01379500 near Chatham, and 01382000 at Two Bridges. The 5-year and periodof-record medians at each station differ only slightly for all constituents (tables 6a, 7a, and 8a). The largest differences are for NH4 and PB at station 01379500 and NH4 and BACT at station 01382000. At each station, ALK, TOC, NA, CL, DO, FDO, TP, NO32, NO2, and BACT show seasonal dependency. TOC at stations 01379000 and 01379500 , SS at station 01379000 , and HARD at stations 01379500 and 01382000 also show seasonal dependency. In the downstream direction (stations 01379000 to 01379500 to 01382000 ), the regression slopes of load to streamflow decrease for ALK, DS, NA, CL, TP, TN, NO32, NO2, TAON, NH4, B, and PB; increase for DO; and remain stable for HARD and TOC. The regression slope of SS load to streamflow at the most upstream station (013790000) is smaller than that at any other station in the study area.

Insufficient data are available for all constituents at stations 01379000 and 01379500 to determine trends in concentrations during low flows. At station 01382000 , trends in concentrations during low flows are positive for HARD, CL, DO, FDO, and NO32; negative for TAON and NH4; and insignificant for TOC, DS, NA, and TN. Data for ALK, SS, TP, NO2, B, $\mathrm{PB}$, and BACT are insufficient to determine trends in concentrations during low flows. The trend in concentrations during high flows is positive for HARD at station 01379000 and for FDO at station 01379500; negative for TAON and NH4 at station 01382000; and significant for TOC, DS, NA, CL, DO, TN, NO32, and BACT at all stations. In addition, the trend was insignificant for FDO, TAON, and NH4 at station 01379500 and for HARD and FDO at station 01382000. Insufficient data are available for analysis of ALK, SS, TP, NO2, B, and PB at stations 01379000 and 01382000, and ALK, SS, NO2, B, and PB at station 01379500.

The AMNET impairment status downstream from station 01379000 is non-impaired (table 6b). The AMNET impairment status at and downstream from station 013795000 is severely impaired (table 7b). No AMNET stations are in the vicinity of station 01382000 (table $8 b)$.

\section{$\underline{\text { Rockawav River }}$}

The two water-quality stations on the Rockaway River-stations 01380500 above Reservoir, at Boonton, and 01381200 at Pine Brook - have slight to moderate differences between the 5-year and period-of-record medians (tables 9a and 10a). The largest variations are for NH4 at both stations. The regression slopes of concentration to streamflow for ALK, TOC, and DO at station 01380500, and TOC, NA, CL, DO, FDO, NO2, and BACT at station 01381200 show seasonal dependency. In the downstream direction (station 01380500 to 01381200 ), the 
Table 6a. Median concentrations, relations of concentration and load to streamflow, and directions of concentration trends for selected waterquality constituents at water-quality station 01379000, Passaic River near Millington, N.J.

[Number in parenthesis is the number of available data; WY, water years; $\mathrm{mg} / \mathrm{L}$, milligrams per liter; $\mathrm{CaCO}_{3}$, calcium carbonate; $\mathrm{C}$, carbon; $\mathrm{Na}$, sodium; $\mathrm{Cl}$, chloride; \%, percent; $\mathrm{P}$, phosphorus; $\mathrm{N}$, nitrogen; $\mu \mathrm{g} / \mathrm{L}$, micrograms per liter; $\mathrm{B}$, boron; $\mathrm{Pb}$, lead; MPN/100 mL, most probable number per 100 milliliters. Regression slopes and trend directions are zero when the slope is not different from zero at the 0.05 significance level; * indicates seasonal dependency (the slope and (or) intercept of growing (April through October) and non-growing (November through March) season data were different at the 0.05 significance level). +, positive trend direction; -, negative trend direction; NA, insufficient data for analysis; ND, undetermined value.]

\begin{tabular}{|c|c|c|c|c|c|c|c|c|c|}
\hline \multirow{3}{*}{$\begin{array}{c}\text { Constituent } \\
\text { Alkalinity, } \mathrm{mg} / \mathrm{L} \text { as } \mathrm{CaCO}_{3}\end{array}$} & \multicolumn{2}{|c|}{ 1989-93 WY } & \multicolumn{7}{|c|}{ 1976-93 WY } \\
\hline & \multicolumn{2}{|c|}{$\begin{array}{c}\text { Median } \\
\text { concentration }\end{array}$} & \multicolumn{2}{|c|}{$\begin{array}{c}\text { Median } \\
\text { concentration }\end{array}$} & \multicolumn{2}{|c|}{$\begin{array}{l}\text { Regression } \\
\text { slope of } \\
\text { concentration to } \\
\text { streamflow }\end{array}$} & \multirow{2}{*}{$\begin{array}{c}\begin{array}{c}\text { Regression } \\
\text { slope of } \\
\text { load to } \\
\text { streamflow }\end{array} \\
0.722\end{array}$} & \multirow{2}{*}{$\begin{array}{c}\begin{array}{c}\text { Low- } \\
\text { flow } \\
\text { trend } \\
\text { direction }\end{array} \\
\text { NA }\end{array}$} & \multirow{2}{*}{$\begin{array}{c}\begin{array}{c}\text { High- } \\
\text { flow } \\
\text { trend } \\
\text { direction }\end{array} \\
\text { NA }\end{array}$} \\
\hline & 53 & $(27)$ & 52 & (74) & -0.278 & $*$ & & & \\
\hline Total hardness, $\mathrm{mg} / \mathrm{L}$ as $\mathrm{CaCO}_{3}$ & 71 & $(27)$ & 67 & $(111)$ & -.173 & & .827 & NA & + \\
\hline Total organic carbon, $\mathrm{mg} / \mathrm{L}$ as $\mathrm{C}$ & 6.8 & $(26)$ & 7.2 & $(106)$ & .087 & $*$ & 1.087 & NA & 0 \\
\hline Suspended sediment, $\mathrm{mg} / \mathrm{L}$ & 7 & (11) & 8 & (27) & 0 & $*$ & .849 & NA & NA \\
\hline Dissolved solids, $\mathrm{mg} / \mathrm{L}$ & 148 & $(27)$ & 138 & $(108)$ & -.128 & & .872 & NA & 0 \\
\hline Dissolved sodium, $\mathrm{mg} / \mathrm{L}$ as $\mathrm{Na}$ & 17 & $(27)$ & 15 & $(111)$ & -.113 & $*$ & .886 & NA & 0 \\
\hline Dissolved chloride, $\mathrm{mg} / \mathrm{L}$ as $\mathrm{Cl}$ & 29 & $(27)$ & 23 & $(111)$ & -.091 & $*$ & .909 & NA & 0 \\
\hline Dissolved oxygen, $\mathrm{mg} / \mathrm{L}$ & 6.0 & $(26)$ & 6.0 & $(110)$ & .106 & $*$ & 1.106 & NA & 0 \\
\hline $\begin{array}{l}\text { Fraction of dissolved oxygen at } \\
\text { saturation, } \%\end{array}$ & 65 & $(26)$ & 63 & $(109)$ & 0 & $*$ & ND & NA & 0 \\
\hline Total phosphorus, $\mathrm{mg} / \mathrm{L}$ as $\mathrm{P}$ & .11 & $(27)$ & .14 & $(78)$ & -.228 & $*$ & .772 & NA & NA \\
\hline Total nitrogen, $\mathrm{mg} / \mathrm{L}$ as $\mathrm{N}$ & .8 & $(27)$ & .9 & (94) & 0 & & 1.046 & NA & 0 \\
\hline Total nitrate plus nitrite, $\mathrm{mg} / \mathrm{L}$ as $\mathrm{N}$ & .21 & $(27)$ & .20 & (96) & .242 & $*$ & 1.242 & NA & 0 \\
\hline Total nitrite, $\mathrm{mg} / \mathrm{L}$ as $\mathrm{N}$ & .007 & $(27)$ & .009 & $(80)$ & 0 & $*$ & 1.012 & NA & NA \\
\hline $\begin{array}{l}\text { Total ammonia plus organic nitrogen, } \\
\mathrm{mg} / \mathrm{L} \text { as } \mathrm{N}\end{array}$ & .56 & $(27)$ & .64 & $(103)$ & 0 & & .928 & NA & 0 \\
\hline Total ammonia, $\mathrm{mg} / \mathrm{L}$ as $\mathrm{N}$ & .04 & $(27)$ & .07 & (94) & 0 & & .832 & NA & 0 \\
\hline Total boron, $\mu \mathrm{g} / \mathrm{L}$ as $\mathrm{B}$ & 60 & (5) & 70 & (17) & 0 & & .930 & NA & NA \\
\hline Total lead, $\mu \mathrm{g} / \mathrm{L}$ as $\mathrm{Pb}$ & 2 & (5) & 3 & (18) & 0 & & 1.333 & NA & NA \\
\hline Fecal coliform bacteria, MPN/100 ml & 160 & (24) & 140 & $(105)$ & 0 & $*$ & ND & NA & 0 \\
\hline
\end{tabular}

Table 6b. 1993 AMNET impairment status in the vicinity of water-quality station 01379000, Passaic River near Millington, N.J.

[AMNET, Ambient Biomonitoring Network; WQ, water-quality. Upstream from WQ station is within 5 miles upstream from the WQ station; at WQ-station location is within 0.5 mile upstream or downstream from the WQ station; downstream from WQ station is within 5 miles downstream from the WQ station; ND, undetermined impairment status]

\begin{tabular}{lccc}
\hline & Upstream from WQ station & At WQ-station location & Downstream from WQ station \\
\hline AMNET station & None & None & AN0224 \\
Impairment status & ND & ND & Non-impaired \\
\hline
\end{tabular}


Table 7a. Median concentrations, relations of concentration and load to streamflow, and directions of concentration trends for selected waterquality constituents at water-quality station 01379500, Passaic River near Chatham, N.J.

[Number in parenthesis is the number of available data; WY, water years; mg/L, milligrams per liter; $\mathrm{CaCO}_{3}$, calcium carbonate; $\mathrm{C}$, carbon; $\mathrm{Na}$, sodium; $\mathrm{Cl}$, chloride; \%, percent; $\mathrm{P}$, phosphorus; $\mathrm{N}$, nitrogen; $\mu \mathrm{g} / \mathrm{L}$, micrograms per liter; $\mathrm{B}$, boron; $\mathrm{Pb}$, lead; MPN/100 mL, most probable number per 100 milliliters. Regression slopes and trend directions are zero when the slope is not different from zero at the 0.05 significance level; * indicates seasonal dependency (the slope and (or) intercept of growing (April through October) and non-growing (November through March) season data were different at the 0.05 significance level). +, positive trend direction; -, negative trend direction; NA, insufficient data for analysis; $\mathrm{ND}$, undetermined value.]

\begin{tabular}{|c|c|c|c|c|c|c|c|c|c|}
\hline \multirow{3}{*}{$\begin{array}{c}\text { Constituent } \\
\text { Alkalinity, } \mathrm{mg} / \mathrm{L} \text { as } \mathrm{CaCO}_{3}\end{array}$} & \multicolumn{2}{|c|}{ 1989-93 WY } & \multicolumn{7}{|c|}{ 1976-93 WY } \\
\hline & \multicolumn{2}{|c|}{$\begin{array}{c}\text { Median } \\
\text { concentration }\end{array}$} & \multicolumn{2}{|c|}{$\begin{array}{c}\text { Median } \\
\text { concentration }\end{array}$} & \multicolumn{2}{|c|}{$\begin{array}{l}\text { Regression } \\
\text { slope of } \\
\text { concentration to } \\
\text { streamflow }\end{array}$} & \multirow{2}{*}{$\begin{array}{c}\begin{array}{c}\text { Regression } \\
\text { slope of } \\
\text { load to } \\
\text { streamflow }\end{array} \\
0.705\end{array}$} & \multirow{2}{*}{$\begin{array}{c}\begin{array}{c}\text { Low- } \\
\text { flow } \\
\text { trend } \\
\text { direction }\end{array} \\
\text { NA }\end{array}$} & \multirow{2}{*}{$\begin{array}{c}\begin{array}{c}\text { High- } \\
\text { flow } \\
\text { trend } \\
\text { direction }\end{array} \\
\text { NA }\end{array}$} \\
\hline & 60 & $(27)$ & 60 & (74) & -0.294 & $*$ & & & \\
\hline Total hardness, $\mathrm{mg} / \mathrm{L}$ as $\mathrm{CaCO}_{3}$ & 91 & $(27)$ & 88 & (111) & -.250 & $*$ & .750 & NA & 0 \\
\hline Total organic carbon, $\mathrm{mg} / \mathrm{L}$ as $\mathrm{C}$ & 6.5 & $(27)$ & 7.0 & $(108)$ & 0 & $*$ & 1.037 & NA & 0 \\
\hline Suspended sediment, mg/L & 21 & $(10)$ & 20 & (24) & 0 & & 1.234 & NA & NA \\
\hline Dissolved solids, mg/L & 215 & $(27)$ & 219 & $(109)$ & -.301 & & .698 & NA & 0 \\
\hline Dissolved sodium, $\mathrm{mg} / \mathrm{L}$ as $\mathrm{Na}$ & 38 & $(27)$ & 40 & (111) & -.427 & $*$ & .573 & NA & 0 \\
\hline Dissolved chloride, $\mathrm{mg} / \mathrm{L}$ as $\mathrm{Cl}$ & 59 & $(27)$ & 57 & (111) & -.388 & $*$ & .612 & NA & 0 \\
\hline Dissolved oxygen, $\mathrm{mg} / \mathrm{L}$ & 8.3 & $(25)$ & 6.5 & $(105)$ & .129 & $*$ & 1.129 & NA & 0 \\
\hline $\begin{array}{l}\text { Fraction of dissolved oxygen at } \\
\text { saturation, } \%\end{array}$ & 85 & $(23)$ & 72 & $(101)$ & .048 & $*$ & ND & NA & + \\
\hline Total phosphorus, $\mathrm{mg} / \mathrm{L}$ as $\mathrm{P}$ & .31 & $(27)$ & .43 & $(106)$ & -.483 & $*$ & .517 & NA & 0 \\
\hline Total nitrogen, $\mathrm{mg} / \mathrm{L}$ as $\mathrm{N}$ & 2.2 & $(27)$ & 2.7 & $(95)$ & -.345 & & .654 & NA & 0 \\
\hline Total nitrate plus nitrite, $\mathrm{mg} / \mathrm{L}$ as $\mathrm{N}$ & 1.27 & $(27)$ & 1.22 & (98) & -.415 & $*$ & .585 & NA & 0 \\
\hline Total nitrite, $\mathrm{mg} / \mathrm{L}$ as $\mathrm{N}$ & .032 & $(27)$ & .058 & $(80)$ & -.725 & $*$ & .275 & NA & NA \\
\hline $\begin{array}{l}\text { Total ammonia plus organic nitrogen, } \\
\mathrm{mg} / \mathrm{L} \text { as } \mathrm{N}\end{array}$ & .87 & $(27)$ & 1.22 & $(106)$ & -.282 & & .718 & NA & 0 \\
\hline Total ammonia, $\mathrm{mg} / \mathrm{L}$ as $\mathrm{N}$ & .17 & $(27)$ & .40 & (99) & -.439 & & .560 & NA & 0 \\
\hline Total boron, $\mu \mathrm{g} / \mathrm{L}$ as $\mathrm{B}$ & 135 & (6) & 140 & $(20)$ & -.412 & & .588 & NA & NA \\
\hline Total lead, $\mu \mathrm{g} / \mathrm{L}$ as $\mathrm{Pb}$ & 2 & (6) & 6 & (24) & 0 & & 1.125 & NA & NA \\
\hline Fecal coliform bacteria, MPN/100 ml & 400 & $(24)$ & 540 & $(106)$ & 0 & $*$ & ND & NA & 0 \\
\hline
\end{tabular}

Table 7b. 1993 AMNET impairment status in the vicinity of water-quality station 01379500, Passaic River near Chatham, N.J.

[AMNET, Ambient Biomonitoring Network; WQ, water-quality. Upstream from WQ station is within 5 miles upstream from the WQ station; at WQ-station location is within 0.5 mile upstream or downstream from the WQ station; downstream from WQ station is within 5 miles downstream from the WQ station; ND, undetermined impairment status]

\begin{tabular}{lccc}
\hline & Upstream from WQ station & At WQ-station location & Downstream from WQ station \\
\hline AMNET station & None & AN0229 & AN0230 \\
Impairment status & ND & Severely impaired & Severely impaired \\
\hline
\end{tabular}


Table 8a. Median concentrations, relations of concentration and load to streamflow, and directions of concentration trends for selected waterquality constituents at water-quality station 01382000, Passaic River at Two Bridges, N.J.

[Number in parenthesis is the number of available data; WY, water years; $\mathrm{mg} / \mathrm{L}$, milligrams per liter; $\mathrm{CaCO}_{3}$, calcium carbonate; $\mathrm{C}$, carbon; $\mathrm{Na}$, sodium; $\mathrm{Cl}$, chloride; \%, percent; $\mathrm{P}$, phosphorus; $\mathrm{N}$, nitrogen; $\mu \mathrm{g} / \mathrm{L}$, micrograms per liter; $\mathrm{B}$, boron; $\mathrm{Pb}$, lead; MPN/100 mL, most probable number per 100 milliliters. Regression slopes and trend directions are zero when the slope is not different from zero at the 0.05 significance level; * indicates seasonal dependency (the slope and (or) intercept of growing (April through October) and non-growing (November through March) season data were different at the 0.05 significance level). +, positive trend direction; -, negative trend direction; NA, insufficient data for analysis; ND, undetermined value.]

\begin{tabular}{|c|c|c|c|c|c|c|c|c|c|}
\hline \multirow{3}{*}{$\begin{array}{c}\text { Constituent } \\
\text { Alkalinity, } \mathrm{mg} / \mathrm{L} \text { as } \mathrm{CaCO}_{3}\end{array}$} & \multicolumn{2}{|c|}{ 1989-93 WY } & \multicolumn{7}{|c|}{ 1976-93 WY } \\
\hline & \multicolumn{2}{|c|}{$\begin{array}{c}\text { Median } \\
\text { concentration }\end{array}$} & \multicolumn{2}{|c|}{$\begin{array}{c}\text { Median } \\
\text { concentration }\end{array}$} & \multicolumn{2}{|c|}{$\begin{array}{l}\text { Regression } \\
\text { slope of } \\
\text { concentration to } \\
\text { streamflow }\end{array}$} & \multirow{2}{*}{$\begin{array}{c}\begin{array}{c}\text { Regression } \\
\text { slope of } \\
\text { load to } \\
\text { streamflow }\end{array} \\
0.677\end{array}$} & \multirow{2}{*}{$\begin{array}{c}\begin{array}{c}\text { Low- } \\
\text { flow } \\
\text { trend } \\
\text { direction }\end{array} \\
\text { NA }\end{array}$} & \multirow{2}{*}{$\begin{array}{c}\begin{array}{c}\text { High- } \\
\text { flow } \\
\text { trend } \\
\text { direction }\end{array} \\
\text { NA }\end{array}$} \\
\hline & 60 & (74) & 61 & (133) & -0.322 & $*$ & & & \\
\hline Total hardness, $\mathrm{mg} / \mathrm{L}$ as $\mathrm{CaCO}_{3}$ & 100 & (73) & 100 & $(169)$ & -.330 & $*$ & .670 & + & 0 \\
\hline Total organic carbon, $\mathrm{mg} / \mathrm{L}$ as $\mathrm{C}$ & 6.0 & $(69)$ & 6.6 & $(159)$ & 0 & $*$ & 1.018 & 0 & 0 \\
\hline Suspended sediment, mg/L & 16 & $(10)$ & 26 & $(20)$ & 0 & & .954 & NA & NA \\
\hline Dissolved solids, $\mathrm{mg} / \mathrm{L}$ & 235 & (73) & 232 & $(168)$ & -.345 & $*$ & .654 & 0 & 0 \\
\hline Dissolved sodium, $\mathrm{mg} / \mathrm{L}$ as $\mathrm{Na}$ & 35 & (73) & 34 & $(169)$ & -.401 & $*$ & .599 & 0 & 0 \\
\hline Dissolved chloride, $\mathrm{mg} / \mathrm{L}$ as $\mathrm{Cl}$ & 55 & (74) & 53 & $(170)$ & -.353 & $*$ & .647 & + & 0 \\
\hline Dissolved oxygen, $\mathrm{mg} / \mathrm{L}$ & 8.0 & $(72)$ & 5.6 & $(167)$ & .163 & $*$ & 1.163 & + & 0 \\
\hline $\begin{array}{l}\text { Fraction of dissolved oxygen at } \\
\text { saturation, } \%\end{array}$ & 80 & $(71)$ & 60 & $(165)$ & .097 & * & ND & + & 0 \\
\hline Total phosphorus, $\mathrm{mg} / \mathrm{L}$ as $\mathrm{P}$ & .41 & $(72)$ & .50 & $(138)$ & -.671 & $*$ & .329 & NA & NA \\
\hline Total nitrogen, $\mathrm{mg} / \mathrm{L}$ as $\mathrm{N}$ & 3.0 & $(72)$ & 3.6 & $(159)$ & -.561 & & .439 & 0 & 0 \\
\hline Total nitrate plus nitrite, $\mathrm{mg} / \mathrm{L}$ as $\mathrm{N}$ & 2.00 & $(73)$ & 1.70 & $(161)$ & -.600 & & .400 & + & 0 \\
\hline Total nitrite, $\mathrm{mg} / \mathrm{L}$ as $\mathrm{N}$ & .040 & (73) & .050 & (139) & -.524 & $*$ & .477 & NA & NA \\
\hline $\begin{array}{l}\text { Total ammonia plus organic nitrogen, } \\
\mathrm{mg} / \mathrm{L} \text { as } \mathrm{N}\end{array}$ & 1.00 & $(72)$ & 1.50 & $(167)$ & -.448 & & .552 & - & - \\
\hline Total ammonia, $\mathrm{mg} / \mathrm{L}$ as $\mathrm{N}$ & .22 & $(60)$ & .68 & $(148)$ & -.639 & & .361 & - & - \\
\hline Total boron, $\mu \mathrm{g} / \mathrm{L}$ as $\mathrm{B}$ & 120 & (5) & 140 & (19) & -.477 & & .523 & NA & NA \\
\hline Total lead, $\mu \mathrm{g} / \mathrm{L}$ as $\mathrm{Pb}$ & 10 & (5) & 10 & $(22)$ & 0 & & .932 & NA & NA \\
\hline Fecal coliform bacteria, MPN/100 ml & 120 & $(23)$ & 330 & $(105)$ & 0 & $*$ & ND & NA & 0 \\
\hline
\end{tabular}

Table 8b. 1993 AMNET impairment status in the vicinity of water-quality station 01382000, Passaic River at Two Bridges, N.J.

[AMNET, Ambient Biomonitoring Network; WQ, water-quality. Upstream from WQ station is within 5 miles upstream from the WQ station; at WQ-station location is within 0.5 mile upstream or downstream from the WQ station; downstream from WQ station is within 5 miles downstream from the WQ station; ND, undetermined impairment status]

\begin{tabular}{lccc}
\hline & Upstream from WQ station & At WQ-station location & Downstream from WQ station \\
\hline AMNET station & None & None & None \\
Impairment status & ND & ND & ND \\
\hline
\end{tabular}


Table 9a. Median concentrations, relations of concentration and load to streamflow, and directions of concentration trends for selected waterquality constituents at water-quality station 01380500, Rockaway River above Reservoir, at Boonton, N.J.

[Number in parenthesis is the number of available data; WY, water years; $\mathrm{mg} / \mathrm{L}$, milligrams per liter; $\mathrm{CaCO}_{3}$, calcium carbonate; $\mathrm{C}$, carbon; $\mathrm{Na}$, sodium; $\mathrm{Cl}$, chloride; \%, percent; $\mathrm{P}$, phosphorus; $\mathrm{N}$, nitrogen; $\mu \mathrm{g} / \mathrm{L}$, micrograms per liter; $\mathrm{B}$, boron; $\mathrm{Pb}$, lead; MPN/100 mL, most probable number per 100 milliliters. Regression slopes and trend directions are zero when the slope is not different from zero at the 0.05 significance level; * indicates seasonal dependency (the slope and (or) intercept of growing (April through October) and non-growing (November through March) season data were different at the 0.05 significance level). +, positive trend direction; -, negative trend direction; NA, insufficient data for analysis; ND, undetermined value.]

\begin{tabular}{|c|c|c|c|c|c|c|c|c|c|}
\hline \multirow{3}{*}{$\begin{array}{c}\text { Constituent } \\
\mathrm{g} / \mathrm{L} \text { as } \mathrm{CaCO}_{3}\end{array}$} & \multicolumn{2}{|c|}{ 1989-93 WY } & \multicolumn{7}{|c|}{ 1976-93 WY } \\
\hline & \multicolumn{2}{|c|}{$\begin{array}{c}\text { Median } \\
\text { concentration }\end{array}$} & \multicolumn{2}{|c|}{$\begin{array}{c}\text { Median } \\
\text { concentration }\end{array}$} & \multicolumn{2}{|c|}{$\begin{array}{c}\text { Regression } \\
\text { slope of } \\
\text { concentration to } \\
\text { streamflow }\end{array}$} & \multirow{2}{*}{$\begin{array}{c}\begin{array}{c}\text { Regression } \\
\text { slope of } \\
\text { load to } \\
\text { streamflow }\end{array} \\
0.627\end{array}$} & \multirow{2}{*}{$\begin{array}{c}\begin{array}{c}\text { Low- } \\
\text { flow } \\
\text { trend } \\
\text { direction }\end{array} \\
\mathrm{NA}\end{array}$} & \multirow{2}{*}{$\begin{array}{c}\begin{array}{c}\text { High- } \\
\text { flow } \\
\text { trend } \\
\text { direction }\end{array} \\
\text { NA }\end{array}$} \\
\hline & 38 & $(11)$ & 48 & $(25)$ & -0.373 & $*$ & & & \\
\hline Total hardness, $\mathrm{mg} / \mathrm{L}$ as $\mathrm{CaCO}_{3}$ & 62 & $(12)$ & 63 & (79) & -.286 & & .714 & NA & NA \\
\hline Total organic carbon, $\mathrm{mg} / \mathrm{L}$ as $\mathrm{C}$ & 3.3 & $(11)$ & 3.9 & (47) & 0 & $*$ & 1.016 & NA & NA \\
\hline Suspended sediment, $\mathrm{mg} / \mathrm{L}$ & 5 & $(10)$ & 4 & $(16)$ & .502 & & 1.497 & NA & NA \\
\hline Dissolved solids, mg/L & 139 & $(10)$ & 125 & (49) & -.236 & & .764 & NA & NA \\
\hline Dissolved sodium, $\mathrm{mg} / \mathrm{L}$ as $\mathrm{Na}$ & 16 & (12) & 14 & $(80)$ & -.155 & & .845 & NA & NA \\
\hline Dissolved chloride, $\mathrm{mg} / \mathrm{L}$ as $\mathrm{Cl}$ & 32 & (13) & 24 & (84) & -.197 & & .803 & NA & NA \\
\hline Dissolved oxygen, $\mathrm{mg} / \mathrm{L}$ & 11.0 & (21) & 10.8 & $(121)$ & .100 & $*$ & 1.100 & 0 & 0 \\
\hline $\begin{array}{l}\text { Fraction of dissolved oxygen at } \\
\text { saturation, } \%\end{array}$ & 101 & $(20)$ & 100 & $(115)$ & 0 & & ND & 0 & 0 \\
\hline Total phosphorus, $\mathrm{mg} / \mathrm{L}$ as $\mathrm{P}$ & .04 & $(20)$ & .03 & $(61)$ & 0 & & 1.039 & NA & NA \\
\hline Total nitrogen, $\mathrm{mg} / \mathrm{L}$ as $\mathrm{N}$ & .9 & $(21)$ & .8 & $(90)$ & 0 & & 1.012 & 0 & NA \\
\hline Total nitrate plus nitrite, $\mathrm{mg} / \mathrm{L}$ as $\mathrm{N}$ & .47 & $(21)$ & .39 & $(107)$ & 0 & & 1.056 & 0 & NA \\
\hline Total nitrite, $\mathrm{mg} / \mathrm{L}$ as $\mathrm{N}$ & .009 & $(21)$ & .008 & $(108)$ & 0 & & .992 & 0 & NA \\
\hline $\begin{array}{l}\text { Total ammonia plus organic nitrogen, } \\
\mathrm{mg} / \mathrm{L} \text { as } \mathrm{N}\end{array}$ & .35 & $(21)$ & .49 & $(106)$ & 0 & & 1.079 & 0 & NA \\
\hline Total ammonia, $\mathrm{mg} / \mathrm{L}$ as $\mathrm{N}$ & .03 & $(21)$ & .07 & (89) & 0 & & 1.023 & 0 & NA \\
\hline Total boron, $\mu \mathrm{g} / \mathrm{L}$ as $\mathrm{B}$ & 20 & (2) & 20 & (2) & ND & & ND & NA & NA \\
\hline Total lead, $\mu \mathrm{g} / \mathrm{L}$ as $\mathrm{Pb}$ & 3 & (4) & 4 & $(36)$ & .637 & & 1.637 & NA & NA \\
\hline Fecal coliform bacteria, MPN/100 ml & 80 & $(21)$ & 50 & $(107)$ & 0 & & ND & 0 & 0 \\
\hline
\end{tabular}

Table 9b. 1993 AMNET impairment status in the vicinity of water-quality station 01380500, Rockaway River above Reservoir, at Boonton, N.J.

[AMNET, Ambient Biomonitoring Network; WQ, water-quality. Upstream from WQ station is within 5 miles upstream from the WQ station; at WQ-station location is within 0.5 mile upstream or downstream from the WQ station; downstream from WQ station is within 5 miles downstream from the WQ station; ND, undetermined impairment status]

\begin{tabular}{lccc}
\hline & Upstream from WQ station & At WQ-station location & Downstream from WQ station \\
\hline AMNET station & None & AN0250 & AN0251 \\
Impairment status & ND & Non-impaired & Moderately impaired \\
\hline
\end{tabular}


Table 10a. Median concentrations, relations of concentration and load to streamflow, and directions of concentration trends for selected waterquality constituents at water-quality station 01381200, Rockaway River at Pine Brook, N.J.

[Number in parenthesis is the number of available data; WY, water years; mg/L, milligrams per liter; $\mathrm{CaCO}_{3}$, calcium carbonate; $\mathrm{C}$, carbon; $\mathrm{Na}$, sodium; Cl, chloride; \%, percent; $\mathrm{P}$, phosphorus; $\mathrm{N}$, nitrogen; $\mu \mathrm{g} / \mathrm{L}$, micrograms per liter; $\mathrm{B}$, boron; $\mathrm{Pb}$, lead; MPN/100 mL, most probable number per 100 milliliters. Regression slopes and trend directions are zero when the slope is not different from zero at the 0.05 significance level; * indicates seasonal dependency (the slope and (or) intercept of growing (April through October) and non-growing (November through March) season data were different at the 0.05 significance level). +, positive trend direction; -, negative trend direction; NA, insufficient data for analysis; $\mathrm{ND}$, undetermined value.]

\begin{tabular}{|c|c|c|c|c|c|c|c|c|c|}
\hline \multirow{3}{*}{$\begin{array}{c}\text { Constituent } \\
\mathrm{ag} / \mathrm{L} \text { as } \mathrm{CaCO}_{3}\end{array}$} & \multicolumn{2}{|c|}{ 1989-93 WY } & \multicolumn{7}{|c|}{ 1976-93 WY } \\
\hline & \multicolumn{2}{|c|}{$\begin{array}{c}\text { Median } \\
\text { concentration }\end{array}$} & \multicolumn{2}{|c|}{$\begin{array}{c}\text { Median } \\
\text { concentration }\end{array}$} & \multicolumn{2}{|c|}{$\begin{array}{c}\text { Regression } \\
\text { slope of } \\
\text { concentration to } \\
\text { streamflow }\end{array}$} & \multirow{2}{*}{$\begin{array}{c}\begin{array}{c}\text { Regression } \\
\text { slope of } \\
\text { load to } \\
\text { streamflow }\end{array} \\
0.687\end{array}$} & \multirow{2}{*}{$\begin{array}{c}\begin{array}{c}\text { Low- } \\
\text { flow } \\
\text { trend } \\
\text { direction }\end{array} \\
\text { NA }\end{array}$} & \multirow{2}{*}{$\begin{array}{c}\begin{array}{c}\text { High- } \\
\text { flow } \\
\text { trend } \\
\text { direction }\end{array} \\
\text { NA }\end{array}$} \\
\hline & 50 & $(26)$ & 57 & (73) & -0.313 & & & & \\
\hline Total hardness, $\mathrm{mg} / \mathrm{L}$ as $\mathrm{CaCO}_{3}$ & 77 & $(25)$ & 89 & $(109)$ & -.287 & & .713 & NA & 0 \\
\hline Total organic carbon, $\mathrm{mg} / \mathrm{L}$ as $\mathrm{C}$ & 4.0 & $(26)$ & 4.7 & $(109)$ & 0 & $*$ & .941 & NA & - \\
\hline Suspended sediment, $\mathrm{mg} / \mathrm{L}$ & 6 & $(10)$ & 11 & $(21)$ & 0 & & 1.153 & NA & NA \\
\hline Dissolved solids, $\mathrm{mg} / \mathrm{L}$ & 155 & $(26)$ & 180 & $(107)$ & -.259 & & .741 & NA & + \\
\hline Dissolved sodium, $\mathrm{mg} / \mathrm{L}$ as $\mathrm{Na}$ & 22 & $(25)$ & 23 & $(109)$ & -.271 & $*$ & .729 & NA & + \\
\hline Dissolved chloride, $\mathrm{mg} / \mathrm{L}$ as $\mathrm{Cl}$ & 40 & $(26)$ & 38 & $(110)$ & -.228 & $*$ & .772 & NA & + \\
\hline Dissolved oxygen, mg/L & 9.0 & (23) & 8.0 & $(107)$ & .200 & * & 1.200 & NA & 0 \\
\hline $\begin{array}{l}\text { Fraction of dissolved oxygen at } \\
\text { saturation, } \%\end{array}$ & 94 & $(22)$ & 82 & $(106)$ & .135 & $*$ & ND & NA & + \\
\hline Total phosphorus, $\mathrm{mg} / \mathrm{L}$ as $\mathrm{P}$ & .15 & $(25)$ & .42 & (79) & -.725 & & .275 & NA & NA \\
\hline Total nitrogen, $\mathrm{mg} / \mathrm{L}$ as $\mathrm{N}$ & 1.8 & $(24)$ & 4.0 & $(90)$ & -.599 & & .401 & NA & NA \\
\hline Total nitrate plus nitrite, $\mathrm{mg} / \mathrm{L}$ as $\mathrm{N}$ & 1.56 & $(25)$ & 1.50 & $(95)$ & -.562 & & .438 & NA & NA \\
\hline Total nitrite, $\mathrm{mg} / \mathrm{L}$ as $\mathrm{N}$ & .014 & $(26)$ & .028 & $(80)$ & -.478 & $*$ & .521 & NA & NA \\
\hline $\begin{array}{l}\text { Total ammonia plus organic nitrogen, } \\
\mathrm{mg} / \mathrm{L} \text { as } \mathrm{N}\end{array}$ & .50 & $(25)$ & .82 & $(104)$ & -.346 & & .654 & NA & - \\
\hline Total ammonia, $\mathrm{mg} / \mathrm{L}$ as $\mathrm{N}$ & .06 & (26) & .22 & (96) & -.418 & & .582 & NA & 0 \\
\hline Total boron, $\mu \mathrm{g} / \mathrm{L}$ as $\mathrm{B}$ & 110 & (6) & 100 & (21) & -.383 & & .617 & NA & NA \\
\hline Total lead, $\mu \mathrm{g} / \mathrm{L}$ as $\mathrm{Pb}$ & 2 & $(6)$ & 5 & (24) & .577 & & 1.577 & NA & NA \\
\hline Fecal coliform bacteria, MPN/100 ml & 350 & $(23)$ & 330 & $(103)$ & -.425 & * & ND & NA & NA \\
\hline
\end{tabular}

Table 10b. 1993 AMNET impairment status in the vicinity of water-quality station 01381200, Rockaway River at Pine Brook, N.J.

[AMNET, Ambient Biomonitoring Network; WQ, water-quality. Upstream from WQ station is within 5 miles upstream from the WQ station; at WQ-station location is within 0.5 mile upstream or downstream from the WQ station; downstream from WQ station is within 5 miles downstream from the WQ station; ND, undetermined impairment status]

\begin{tabular}{lccc}
\hline & Upstream from WQ station & At WQ-station location & Downstream from WQ station \\
\hline AMNET station & AN0251 & None & None \\
Impairment status & Moderately impaired & ND & ND \\
\hline
\end{tabular}


regression slopes of load to streamflow decrease for the six nutrients (TP, TN, NO32, NO2, TAON, and NH4) and PB, and increase for DO. The slopes of ALK, HARD, TOC, SS, DS, NA, and CL remain relatively stable or are the same in the downstream direction. The slope of $\mathrm{B}$ is undetermined at station 01380500 and moderate at station 01381200.

At station 01380500, the trends are insignificant for DO, FDO, TN, NO32, NO2, TAON, $\mathrm{NH} 4$, and BACT during low flows. Insufficient data are available for ALK, HARD, TOC, SS, DS, NA, CL, TP, B, and PB at station 01380500, and all 18 constituents at station 01381200 for analysis. Trends in concentrations during high flows at station 01380500 indicates no trend for DO, FDO, and BACT, and insufficient data are available for all other constituents to determine trends. The trends in concentration during high flows at station 01381200 were positive for DS, NA, CL, and FDO; negative for TOC and TAON; and insignificant for HARD, DO, and NH4. Insufficient data are available for all other constituents to determine trends.

The AMNET impairment status for station 01380500 is non-impaired at the station and moderately impaired downstream (table 9b). The AMNET impairment status upstream from station 01381200 is moderately impaired (table 10b).

\section{Whippany River}

Two water-quality stations are located on the Whippany River- 01381500 at Morristown and 01381800 near Pine Brook. The 5-year and period-of-record medians for most constituents differ only slightly at both stations (tables 11a and 12a). The greatest differences are for PB at station 01381500 and BACT at both stations. SS, DS, NA, CL, DO, and NO2 at station 01381500 and HARD, TOC, SS, DS, NA, CL, DO, FDO, and NO2 at station 01381800 show seasonal dependency. In the downstream direction (station 01381500 to 01381800 ), the regression slopes of load to streamflow decrease for HARD, SS, DS, TP, TN, NO32, NO2, TAON, NH4, B, and PB; increase for DO; and remain relatively stable or are unchanged for ALK, NA, and CL.

Insufficient data for all constituents at stations 01381500 and 01381800 are available to determine trends in concentration during low flows. At station 01381500 , the trends in concentration during high flows are insignificant for HARD, TOC, DS, NA, CL, DO, FDO, TN, NO32, TAON, NH4, and BACT; insufficient data are available for all other constituents to determine high-flow trends. At station 01381800, trends are positive for CL and DO; negative for BACT; and insignificant for HARD, TOC, DS, NA, FDO, TN, NO32, TAON, and NH4. Insufficient data are available for all other constituents to determine trends.

The AMNET impairment status upstream and downstream from station 01381500 is moderately impaired (table 11b). The AMNET impairment status at station 01381800 is moderately impaired (table $12 \mathrm{~b}$ ). 
Table 11a. Median concentrations, relations of concentration and load to streamflow, and directions of concentration trends for selected waterquality constituents at water-quality station 01381500, Whippany River at Morristown, N.J.

[Number in parenthesis is the number of available data; WY, water years; $\mathrm{mg} / \mathrm{L}$, milligrams per liter; $\mathrm{CaCO}_{3}$, calcium carbonate; $\mathrm{C}$, carbon; $\mathrm{Na}$, sodium; $\mathrm{Cl}$, chloride; \%, percent; $\mathrm{P}$, phosphorus; $\mathrm{N}$, nitrogen; $\mu \mathrm{g} / \mathrm{L}$, micrograms per liter; $\mathrm{B}$, boron; $\mathrm{Pb}$, lead; MPN/100 mL, most probable number per 100 milliliters. Regression slopes and trend directions are zero when the slope is not different from zero at the 0.05 significance level; * indicates seasonal dependency (the slope and (or) intercept of growing (April through October) and non-growing (November through March) season data were different at the 0.05 significance level). +, positive trend direction; -, negative trend direction; NA, insufficient data for analysis; ND, undetermined value.]

\begin{tabular}{|c|c|c|c|c|c|c|c|c|c|}
\hline \multirow{3}{*}{$\begin{array}{c}\text { Constituent } \\
\mathrm{ag} / \mathrm{L} \text { as } \mathrm{CaCO}_{3}\end{array}$} & \multicolumn{2}{|c|}{ 1989-93 WY } & \multicolumn{7}{|c|}{ 1976-93 WY } \\
\hline & \multicolumn{2}{|c|}{$\begin{array}{l}\text { Median } \\
\text { concentration }\end{array}$} & \multicolumn{2}{|c|}{$\begin{array}{l}\text { Median } \\
\text { concentration }\end{array}$} & \multicolumn{2}{|c|}{$\begin{array}{c}\text { Regression } \\
\text { slope of } \\
\text { concentration to } \\
\text { streamflow }\end{array}$} & \multirow{2}{*}{$\begin{array}{c}\begin{array}{c}\text { Regression } \\
\text { slope of } \\
\text { load to } \\
\text { streamflow }\end{array} \\
0.637\end{array}$} & \multirow{2}{*}{$\begin{array}{c}\begin{array}{c}\text { Low- } \\
\text { flow } \\
\text { trend } \\
\text { direction }\end{array} \\
\text { NA }\end{array}$} & \multirow{2}{*}{$\begin{array}{c}\begin{array}{c}\text { High- } \\
\text { flow } \\
\text { trend } \\
\text { direction }\end{array} \\
\text { NA }\end{array}$} \\
\hline & 55 & $(27)$ & 56 & (73) & -0.363 & & & & \\
\hline Total hardness, $\mathrm{mg} / \mathrm{L}$ as $\mathrm{CaCO}_{3}$ & 92 & $(27)$ & 84 & $(111)$ & -.308 & & .692 & NA & 0 \\
\hline Total organic carbon, $\mathrm{mg} / \mathrm{L}$ as $\mathrm{C}$ & 3.6 & $(26)$ & 3.8 & $(107)$ & 0 & & 1.066 & NA & 0 \\
\hline Suspended sediment, $\mathrm{mg} / \mathrm{L}$ & 7 & $(10)$ & 7 & (26) & .726 & $*$ & 1.726 & NA & NA \\
\hline Dissolved solids, $\mathrm{mg} / \mathrm{L}$ & 188 & $(26)$ & 181 & $(108)$ & -.247 & $*$ & .753 & NA & 0 \\
\hline Dissolved sodium, $\mathrm{mg} / \mathrm{L}$ as $\mathrm{Na}$ & 22 & $(27)$ & 20 & $(111)$ & -.257 & $*$ & .743 & NA & 0 \\
\hline Dissolved chloride, $\mathrm{mg} / \mathrm{L}$ as $\mathrm{Cl}$ & 49 & $(27)$ & 37 & $(111)$ & -.221 & $*$ & .779 & NA & 0 \\
\hline Dissolved oxygen, mg/L & 10.8 & (26) & 10.8 & $(109)$ & 0 & $*$ & .990 & NA & 0 \\
\hline $\begin{array}{l}\text { Fraction of dissolved oxygen at } \\
\text { saturation, } \%\end{array}$ & 104 & $(25)$ & 107 & $(108)$ & -.076 & & ND & NA & 0 \\
\hline Total phosphorus, $\mathrm{mg} / \mathrm{L}$ as $\mathrm{P}$ & .18 & $(27)$ & .26 & (79) & -.232 & & .768 & NA & NA \\
\hline Total nitrogen, $\mathrm{mg} / \mathrm{L}$ as $\mathrm{N}$ & 2.1 & $(27)$ & 2.3 & (95) & -.172 & & .828 & NA & 0 \\
\hline Total nitrate plus nitrite, $\mathrm{mg} / \mathrm{L}$ as $\mathrm{N}$ & 1.49 & $(27)$ & 1.45 & (99) & -.261 & & .739 & NA & 0 \\
\hline Total nitrite, $\mathrm{mg} / \mathrm{L}$ as $\mathrm{N}$ & .042 & $(27)$ & .054 & $(81)$ & -.431 & $*$ & .569 & NA & NA \\
\hline $\begin{array}{l}\text { Total ammonia plus organic nitrogen, } \\
\mathrm{mg} / \mathrm{L} \text { as } \mathrm{N}\end{array}$ & .55 & $(27)$ & .81 & $(105)$ & 0 & & .949 & NA & 0 \\
\hline Total ammonia, $\mathrm{mg} / \mathrm{L}$ as $\mathrm{N}$ & .11 & $(27)$ & .18 & (97) & 0 & & 1.144 & NA & 0 \\
\hline Total boron, $\mu \mathrm{g} / \mathrm{L}$ as $\mathrm{B}$ & 40 & (6) & 40 & (19) & 0 & & .852 & NA & NA \\
\hline Total lead, $\mu \mathrm{g} / \mathrm{L}$ as $\mathrm{Pb}$ & 2 & (6) & 5 & $(21)$ & .660 & & 1.660 & NA & NA \\
\hline Fecal coliform bacteria, MPN/100 ml & 800 & $(24)$ & 2000 & $(108)$ & .688 & & ND & NA & 0 \\
\hline
\end{tabular}

Table 11b. 1993 AMNET impairment status in the vicinity of water-quality station 01381500, Whippany River at Morristown, N.J.

[AMNET, Ambient Biomonitoring Network; WQ, water-quality. Upstream from WQ station is within 5 miles upstream from the WQ station; at WQ-station location is within 0.5 mile upstream or downstream from the WQ station; downstream from WQ station is within 5 miles downstream from the WQ station; ND, undetermined impairment status]

\begin{tabular}{lccc}
\hline & Upstream from WQ station & At WQ-station location & Downstream from WQ station \\
\hline AMNET station & AN0234 & None & AN0235 \\
Impairment status & Moderately impaired & ND & Moderately impaired \\
\hline
\end{tabular}


Table 12a. Median concentrations, relations of concentration and load to streamflow, and directions of concentration trends for selected waterquality constituents at water-quality station 01381800, Whippany River near Pine Brook, N.J.

[Number in parenthesis is the number of available data; WY, water years; mg/L, milligrams per liter; $\mathrm{CaCO}_{3}$, calcium carbonate; $\mathrm{C}$, carbon; $\mathrm{Na}$, sodium; $\mathrm{Cl}$, chloride; \%, percent; $\mathrm{P}$, phosphorus; $\mathrm{N}$, nitrogen; $\mu \mathrm{g} / \mathrm{L}$, micrograms per liter; $\mathrm{B}$, boron; $\mathrm{Pb}$, lead; MPN/100 mL, most probable number per 100 milliliters. Regression slopes and trend directions are zero when the slope is not different from zero at the 0.05 significance level; * indicates seasonal dependency (the slope and (or) intercept of growing (April through October) and non-growing (November through March) season data were different at the 0.05 significance level). +, positive trend direction; -, negative trend direction; NA, insufficient data for analysis; ND, undetermined value.]

\begin{tabular}{|c|c|c|c|c|c|c|c|c|c|}
\hline \multirow{3}{*}{$\begin{array}{c}\text { Constituent } \\
\mathrm{ag} / \mathrm{L} \text { as } \mathrm{CaCO}_{3}\end{array}$} & \multicolumn{2}{|c|}{ 1989-93 WY } & \multicolumn{7}{|c|}{ 1976-93 WY } \\
\hline & \multicolumn{2}{|c|}{$\begin{array}{c}\text { Median } \\
\text { concentration }\end{array}$} & \multicolumn{2}{|c|}{$\begin{array}{c}\text { Median } \\
\text { concentration }\end{array}$} & \multicolumn{2}{|c|}{$\begin{array}{c}\text { Regression } \\
\text { slope of } \\
\text { concentration to } \\
\text { streamflow }\end{array}$} & \multirow{2}{*}{$\begin{array}{c}\begin{array}{c}\text { Regression } \\
\text { slope of } \\
\text { load to } \\
\text { streamflow }\end{array} \\
0.617\end{array}$} & \multirow{2}{*}{$\begin{array}{c}\begin{array}{c}\text { Low- } \\
\text { flow } \\
\text { trend } \\
\text { direction }\end{array} \\
\text { NA }\end{array}$} & \multirow{2}{*}{$\begin{array}{c}\begin{array}{c}\text { High- } \\
\text { flow } \\
\text { trend } \\
\text { direction }\end{array} \\
\text { NA }\end{array}$} \\
\hline & 72 & $(27)$ & 76 & (73) & -0.382 & & & & \\
\hline Total hardness, $\mathrm{mg} / \mathrm{L}$ as $\mathrm{CaCO}_{3}$ & 110 & (26) & 120 & $(109)$ & -.358 & $*$ & .641 & NA & 0 \\
\hline Total organic carbon, $\mathrm{mg} / \mathrm{L}$ as $\mathrm{C}$ & 5.8 & $(25)$ & 6.8 & $(107)$ & 0 & $*$ & 1.075 & NA & 0 \\
\hline Suspended sediment, $\mathrm{mg} / \mathrm{L}$ & 17 & $(11)$ & 20 & (24) & 0 & $*$ & 1.153 & NA & NA \\
\hline Dissolved solids, $\mathrm{mg} / \mathrm{L}$ & 227 & $(26)$ & 232 & $(109)$ & -.296 & $*$ & .704 & NA & 0 \\
\hline Dissolved sodium, $\mathrm{mg} / \mathrm{L}$ as $\mathrm{Na}$ & 31 & (27) & 28 & $(110)$ & -.277 & $*$ & .723 & NA & 0 \\
\hline Dissolved chloride, $\mathrm{mg} / \mathrm{L}$ as $\mathrm{Cl}$ & 58 & $(27)$ & 42 & $(110)$ & -.215 & $*$ & .785 & NA & + \\
\hline Dissolved oxygen, $\mathrm{mg} / \mathrm{L}$ & 8.0 & (27) & 6.3 & $(111)$ & .138 & $*$ & 1.138 & NA & + \\
\hline $\begin{array}{l}\text { Fraction of dissolved oxygen at } \\
\text { saturation, } \%\end{array}$ & 80 & $(26)$ & 66 & $(110)$ & 0 & $*$ & ND & NA & 0 \\
\hline Total phosphorus, $\mathrm{mg} / \mathrm{L}$ as $\mathrm{P}$ & .30 & $(26)$ & .43 & (79) & -.549 & & .451 & NA & NA \\
\hline Total nitrogen, $\mathrm{mg} / \mathrm{L}$ as $\mathrm{N}$ & 2.9 & $(26)$ & 3.6 & (93) & -.495 & & .504 & NA & 0 \\
\hline Total nitrate plus nitrite, $\mathrm{mg} / \mathrm{L}$ as $\mathrm{N}$ & 1.64 & $(26)$ & 1.50 & (97) & -.480 & & .520 & NA & 0 \\
\hline Total nitrite, $\mathrm{mg} / \mathrm{L}$ as $\mathrm{N}$ & .054 & $(27)$ & .092 & $(80)$ & -.813 & $*$ & 0 & NA & NA \\
\hline $\begin{array}{l}\text { Total ammonia plus organic nitrogen, } \\
\mathrm{mg} / \mathrm{L} \text { as } \mathrm{N}\end{array}$ & 1.20 & (27) & 1.76 & $(104)$ & -.450 & & .550 & NA & 0 \\
\hline Total ammonia, $\mathrm{mg} / \mathrm{L}$ as $\mathrm{N}$ & .34 & $(27)$ & .78 & (96) & -.549 & & .451 & NA & 0 \\
\hline Total boron, $\mu \mathrm{g} / \mathrm{L}$ as $\mathrm{B}$ & 75 & (6) & 90 & (19) & -.550 & & .450 & NA & NA \\
\hline Total lead, $\mu \mathrm{g} / \mathrm{L}$ as $\mathrm{Pb}$ & 6 & (6) & 10 & (22) & .539 & & 1.539 & NA & NA \\
\hline Fecal coliform bacteria, MPN/100 ml & 280 & (24) & 920 & $(105)$ & 0 & & ND & NA & - \\
\hline
\end{tabular}

Table 12b. 1993 AMNET impairment status in the vicinity of water-quality station 01381800, Whippany River near Pine Brook, N.J.

[AMNET, Ambient Biomonitoring Network; WQ, water-quality. Upstream from WQ station is within 5 miles upstream from the WQ station; at WQ-station location is within 0.5 mile upstream or downstream from the WQ station; downstream from WQ station is within 5 miles downstream from the WQ station; ND, undetermined impairment status]

\begin{tabular}{lccc} 
& Upstream from WQ station & At WQ-station location & Downstream from WQ station \\
\hline AMNET station & None & AN0238 & None \\
Impairment status & None & Moderately impaired & ND \\
\hline
\end{tabular}




\section{Pequannock River}

Station 01382500 at Macopin Intake Dam is the only water-quality station on the Pequannock River. The 5-year and period-of-record medians are similar for all constituents (table 13a). Of all 19 stations, this station has the lowest 5-year medians for 10 constituents-ALK, HARD, DS, NA, TP, TN, NO2, TAON, B, and BACT-and the lowest period-of-record medians for 13 constituents-ALK, HARD, SS, DS, CL, TP, TN, NO32, NO2, TAON, B, PB, and BACT (table 13a). The regression slopes of concentration to streamflow for TOC, DO, TP, NO32, and BACT show seasonal dependency. The regression slopes of load to streamflow for all constituents fall within the moderate to high range, indicating a moderate to high relative contribution from surface runoff at these sites compared to other sites in the study area. Insufficient data are available for all constituents at this station to determine trends in concentrations during low and high flows. The AMNET impairment status at and downstream from station 01382500 is non-impaired (table 13b).

\section{$\underline{\text { Ramapo River }}$}

The two water-quality stations on the Ramapo River are stations 01387500 near Mahwah and 01388000 at Pompton Lakes. The 5-year and period-of-record medians differ only slightly for all constituents (tables 14a and 15a). The regression slopes of concentration to streamflow for NA, CL, DO, FDO, TN, and BACT at station 01387500 and ALK, TOC, DS, NA, CL, DO, NO32, and TAON at station 01388000 indicate seasonal dependency. In the downstream direction (stations 01387500 to 01388000 ), the regression slope of load to streamflow decreases for DO, increases by almost twofold for five of the six nutrients species, and remains relatively stable or unchanged for ALK, HARD, TOC, DO, NA, and CL.

At station 01387500, trends in concentrations during low flows are positive for DO and BACT, negative for TAON and NH4, and insignificant for HARD, TOC, DS, NA, CL, FDO, TN, and NO32. Insufficient data are available for all other constituents to determine trends in concentrations during low flows. At station 01388000, insufficient data are available for all constituents to determine trends in concentrations during low flows. At both stations, trends in concentrations during high flows cannot be determined because of insufficient data.

The AMNET impairment status at station 01387500 is moderately impaired (table 14b). The AMNET impairment status upstream of station 01388000 is moderately impaired (table 15b).

\section{Pompton River}

Station 01388600 at Packanack Lake is the only water-quality station on the Pompton River. The 5-year and period-of-record medians are similar for all constituents (table 16a). The regression slopes of concentration to streamflow show seasonal dependency for TOC, DS, NA, CL, DO, FDO, TP, NO32, NO2, and TAON. The regression slopes of load to streamflow are in the low range for TOC and PB; in the moderate range for ALK, HARD, SS, DS, NA, CL, B, and all nutrient species; and in the high range for DO. Insufficient data are available for all constituents to determine trends in concentrations during low and high flows. The AMNET impairment status at station 01388600 is moderately impaired (table 16b). 
Table 13a. Median concentrations, relations of concentration and load to streamflow, and directions of concentration trends for selected waterquality constituents at water-quality station 01382500, Pequannock River at Macopin Intake Dam, N.J.

[Number in parenthesis is the number of available data; WY, water years; mg/L, milligrams per liter; $\mathrm{CaCO}_{3}$, calcium carbonate; $\mathrm{C}$, carbon; $\mathrm{Na}$, sodium; $\mathrm{Cl}$, chloride; \%, percent; $\mathrm{P}$, phosphorus; $\mathrm{N}$, nitrogen; $\mu \mathrm{g} / \mathrm{L}$, micrograms per liter; $\mathrm{B}$, boron; $\mathrm{Pb}$, lead; MPN/100 mL, most probable number per 100 milliliters. Regression slopes and trend directions are zero when the slope is not different from zero at the 0.05 significance level; * indicates seasonal dependency (the slope and (or) intercept of growing (April through October) and non-growing (November through March) season data were different at the 0.05 significance level). +, positive trend direction; -, negative trend direction; NA, insufficient data for analysis; $\mathrm{ND}$, undetermined value.]

\begin{tabular}{|c|c|c|c|c|c|c|c|c|c|}
\hline \multirow{3}{*}{$\begin{array}{c}\text { Constituent } \\
\text { Alkalinity, } \mathrm{mg} / \mathrm{L} \text { as } \mathrm{CaCO}_{3}\end{array}$} & \multicolumn{2}{|c|}{ 1989-93 WY } & \multicolumn{7}{|c|}{ 1976-93 WY } \\
\hline & \multicolumn{2}{|c|}{$\begin{array}{c}\text { Median } \\
\text { concentration }\end{array}$} & \multicolumn{2}{|c|}{$\begin{array}{c}\text { Median } \\
\text { concentration }\end{array}$} & \multicolumn{2}{|c|}{$\begin{array}{l}\text { Regression } \\
\text { slope of } \\
\text { concentration to } \\
\text { streamflow }\end{array}$} & \multirow{2}{*}{$\begin{array}{c}\begin{array}{c}\text { Regression } \\
\text { slope of } \\
\text { load to } \\
\text { streamflow }\end{array} \\
0.869\end{array}$} & \multirow{2}{*}{$\begin{array}{c}\text { Low- } \\
\text { flow } \\
\text { trend } \\
\text { direction } \\
\text { NA }\end{array}$} & \multirow{2}{*}{$\begin{array}{l}\text { High- } \\
\text { flow } \\
\text { trend } \\
\text { direction } \\
\text { NA }\end{array}$} \\
\hline & 32 & (11) & 32 & (11) & -0.131 & & & & \\
\hline Total hardness, $\mathrm{mg} / \mathrm{L}$ as $\mathrm{CaCO}_{3}$ & 54 & (11) & 51 & $(62)$ & -.130 & & .870 & NA & NA \\
\hline Total organic carbon, $\mathrm{mg} / \mathrm{L}$ as $\mathrm{C}$ & 4.0 & (8) & 5.0 & $(32)$ & 0 & $*$ & .959 & NA & NA \\
\hline Suspended sediment, mg/L & 4 & (10) & 3 & (15) & 0 & & 1.174 & NA & NA \\
\hline Dissolved solids, mg/L & 119 & (11) & 104 & $(35)$ & -.114 & & .886 & NA & NA \\
\hline Dissolved sodium, $\mathrm{mg} / \mathrm{L}$ as $\mathrm{Na}$ & 16 & (13) & 12 & (64) & -.144 & & .856 & NA & NA \\
\hline Dissolved chloride, $\mathrm{mg} / \mathrm{L}$ as $\mathrm{Cl}$ & 32 & (14) & 21 & (68) & -.170 & & .830 & NA & NA \\
\hline Dissolved oxygen, $\mathrm{mg} / \mathrm{L}$ & 10.8 & (22) & 10.6 & $(102)$ & .061 & $*$ & 1.043 & NA & NA \\
\hline $\begin{array}{l}\text { Fraction of dissolved oxygen at } \\
\text { saturation, } \%\end{array}$ & 100 & $(21)$ & 97 & $(100)$ & .011 & & ND & NA & NA \\
\hline Total phosphorus, $\mathrm{mg} / \mathrm{L}$ as $\mathrm{P}$ & .04 & $(22)$ & .03 & $(62)$ & 0 & $*$ & .873 & NA & NA \\
\hline Total nitrogen, $\mathrm{mg} / \mathrm{L}$ as $\mathrm{N}$ & 6 & $(21)$ & 6 & (88) & 0 & & 1.003 & NA & NA \\
\hline Total nitrate plus nitrite, $\mathrm{mg} / \mathrm{L}$ as $\mathrm{N}$ & .25 & $(21)$ & .17 & $(90)$ & 0 & $*$ & 1.096 & NA & NA \\
\hline Total nitrite, $\mathrm{mg} / \mathrm{L}$ as $\mathrm{N}$ & .005 & $(21)$ & .006 & (88) & 0 & & 1.018 & NA & NA \\
\hline $\begin{array}{l}\text { Total ammonia plus organic nitrogen, } \\
\mathrm{mg} / \mathrm{L} \text { as } \mathrm{N}\end{array}$ & .32 & (21) & .43 & (99) & 0 & & .979 & NA & NA \\
\hline Total ammonia, $\mathrm{mg} / \mathrm{L}$ as $\mathrm{N}$ & .04 & $(21)$ & .07 & $(86)$ & 0 & & .907 & NA & NA \\
\hline Total boron, $\mu \mathrm{g} / \mathrm{L}$ as $\mathrm{B}$ & $<10$ & (1) & $<10$ & (1) & ND & & ND & NA & NA \\
\hline Total lead, $\mu \mathrm{g} / \mathrm{L}$ as $\mathrm{Pb}$ & 3 & (4) & 2 & $(35)$ & 0 & & 1.180 & NA & NA \\
\hline Fecal coliform bacteria, MPN/100 ml & 13 & $(22)$ & 17 & $(104)$ & 0 & $*$ & ND & NA & NA \\
\hline
\end{tabular}

Table 13b. 1993 AMNET impairment status in the vicinity of water-quality station 01382500, Pequannock River at Macopin Intake Dam, N.J.

[AMNET, Ambient Biomonitoring Network; WQ, water-quality. Upstream from WQ station is within 5 miles upstream from the WQ station; at WQ-station location is within 0.5 mile upstream or downstream from the WQ station; downstream from WQ station is within 5 miles downstream from the WQ station; ND, undetermined impairment status]

\begin{tabular}{lccr}
\hline & Upstream from WQ station & At WQ-station location & Downstream from WQ station \\
\hline AMNET station & None & AN0264 & AN0265 \\
Impairment status & ND & Non-impaired & Non-impaired \\
\hline
\end{tabular}


Table 14a. Median concentrations, relations of concentration and load to streamflow, and directions of concentration trends for selected waterquality constituents at water-quality station 01387500, Ramapo River near Mahwah, N.J.

[Number in parenthesis is the number of available data; WY, water years; $\mathrm{mg} / \mathrm{L}$, milligrams per liter; $\mathrm{CaCO}_{3}$, calcium carbonate; $\mathrm{C}$, carbon; $\mathrm{Na}$, sodium; $\mathrm{Cl}$, chloride; \%, percent; $\mathrm{P}$, phosphorus; $\mathrm{N}$, nitrogen; $\mu \mathrm{g} / \mathrm{L}$, micrograms per liter; $\mathrm{B}$, boron; $\mathrm{Pb}$, lead; MPN/100 mL, most probable number per 100 milliliters. Regression slopes and trend directions are zero when the slope is not different from zero at the 0.05 significance level; * indicates seasonal dependency (the slope and (or) intercept of growing (April through October) and non-growing (November through March) season data were different at the 0.05 significance level). +, positive trend direction; -, negative trend direction; NA, insufficient data for analysis; ND, undetermined value.]

\begin{tabular}{|c|c|c|c|c|c|c|c|c|c|}
\hline \multirow{3}{*}{$\begin{array}{l}\text { Constituent } \\
\mathrm{ig} / \mathrm{L} \text { as } \mathrm{CaCO}_{3}\end{array}$} & \multicolumn{2}{|c|}{ 1989-93 WY } & \multicolumn{7}{|c|}{ 1976-93 WY } \\
\hline & \multicolumn{2}{|c|}{$\begin{array}{c}\text { Median } \\
\text { concentration }\end{array}$} & \multicolumn{2}{|c|}{$\begin{array}{c}\text { Median } \\
\text { concentration }\end{array}$} & \multicolumn{2}{|c|}{$\begin{array}{l}\text { Regression } \\
\text { slope of } \\
\text { concentration to } \\
\text { streamflow }\end{array}$} & \multirow{2}{*}{$\begin{array}{c}\begin{array}{c}\text { Regression } \\
\text { slope of } \\
\text { load to } \\
\text { streamflow }\end{array} \\
0.714\end{array}$} & \multirow{2}{*}{$\begin{array}{c}\begin{array}{c}\text { Low- } \\
\text { flow } \\
\text { trend } \\
\text { direction }\end{array} \\
\text { NA }\end{array}$} & \multirow{2}{*}{$\begin{array}{c}\begin{array}{c}\text { High- } \\
\text { flow } \\
\text { trend } \\
\text { direction }\end{array} \\
\text { NA }\end{array}$} \\
\hline & 60 & $(27)$ & 67 & $(75)$ & -0.286 & & & & \\
\hline Total hardness, $\mathrm{mg} / \mathrm{L}$ as $\mathrm{CaCO}_{3}$ & 87 & $(27)$ & 90 & $(112)$ & -.264 & & .736 & 0 & NA \\
\hline Total organic carbon, $\mathrm{mg} / \mathrm{L}$ as $\mathrm{C}$ & 3.3 & $(25)$ & 3.8 & $(108)$ & -.105 & & .895 & 0 & NA \\
\hline Suspended sediment, $\mathrm{mg} / \mathrm{L}$ & 6 & $(8)$ & 8 & $(20)$ & 0 & & 1.233 & NA & NA \\
\hline Dissolved solids, mg/L & 191 & $(24)$ & 196 & $(108)$ & -.244 & & .756 & 0 & NA \\
\hline Dissolved sodium, $\mathrm{mg} / \mathrm{L}$ as $\mathrm{Na}$ & 30 & $(27)$ & 28 & $(112)$ & -.258 & $*$ & .742 & 0 & NA \\
\hline Dissolved chloride, $\mathrm{mg} / \mathrm{L}$ as $\mathrm{Cl}$ & 56 & $(27)$ & 50 & $(111)$ & -.257 & $*$ & .742 & 0 & NA \\
\hline Dissolved oxygen, $\mathrm{mg} / \mathrm{L}$ & 10.9 & (26) & 9.4 & $(109)$ & .197 & $*$ & 1.197 & + & NA \\
\hline $\begin{array}{l}\text { Fraction of dissolved oxygen at } \\
\text { saturation, } \%\end{array}$ & 102 & $(25)$ & 96 & $(107)$ & .123 & * & ND & 0 & NA \\
\hline Total phosphorus, $\mathrm{mg} / \mathrm{L}$ as $\mathrm{P}$ & .13 & $(25)$ & .16 & $(80)$ & -.498 & & .502 & NA & NA \\
\hline Total nitrogen, $\mathrm{mg} / \mathrm{L}$ as $\mathrm{N}$ & 1.7 & $(27)$ & 1.9 & (93) & -.384 & * & .616 & 0 & NA \\
\hline Total nitrate plus nitrite, $\mathrm{mg} / \mathrm{L}$ as $\mathrm{N}$ & 1.14 & $(27)$ & 1.07 & (93) & -.379 & & .621 & 0 & NA \\
\hline Total nitrite, $\mathrm{mg} / \mathrm{L}$ as $\mathrm{N}$ & .025 & $(27)$ & .024 & $(80)$ & -.504 & & .496 & NA & NA \\
\hline $\begin{array}{l}\text { Total ammonia plus organic nitrogen, } \\
\mathrm{mg} / \mathrm{L} \text { as } \mathrm{N}\end{array}$ & .50 & $(27)$ & .79 & $(107)$ & -.327 & & 673 & - & NA \\
\hline Total ammonia, $\mathrm{mg} / \mathrm{L}$ as $\mathrm{N}$ & .13 & $(27)$ & .23 & (97) & -.413 & & .587 & - & NA \\
\hline Total boron, $\mu \mathrm{g} / \mathrm{L}$ as $\mathrm{B}$ & 40 & $(5)$ & 40 & $(17)$ & -.561 & & .439 & NA & NA \\
\hline Total lead, $\mu \mathrm{g} / \mathrm{L}$ as $\mathrm{Pb}$ & 3 & $(5)$ & 3 & (19) & 0 & & .867 & NA & NA \\
\hline Fecal coliform bacteria, MPN/100 ml & 240 & $(25)$ & $<220$ & $(100)$ & -.492 & $*$ & ND & + & NA \\
\hline
\end{tabular}

Table 14b. 1993 AMNET impairment status in the vicinity of water-quality station 01387500, Ramapo River near Mahwah, N.J.

[AMNET, Ambient Biomonitoring Network; WQ, water-quality. Upstream from WQ station is within 5 miles upstream from the WQ station; at WQ-station location is within 0.5 mile upstream or downstream from the WQ station; downstream from WQ station is within 5 miles downstream from the WQ station; ND, undetermined impairment status]

\begin{tabular}{lccc}
\hline & Upstream from WQ station & At WQ-station location & Downstream from WQ station \\
\hline AMNET station & None & AN0266 & None \\
Impairment status & None & Moderately impaired & ND \\
\hline
\end{tabular}


Table 15a. Median concentrations, relations of concentration and load to streamflow, and directions of concentration trends for selected waterquality constituents at water-quality station 01388000, Ramapo River at Pompton Lakes, N.J.

[Number in parenthesis is the number of available data; WY, water years; mg/L, milligrams per liter; $\mathrm{CaCO}_{3}$, calcium carbonate; $\mathrm{C}$, carbon; $\mathrm{Na}$, sodium; $\mathrm{Cl}$, chloride; \%, percent; $\mathrm{P}$, phosphorus; $\mathrm{N}$, nitrogen; $\mu \mathrm{g} / \mathrm{L}$, micrograms per liter; $\mathrm{B}$, boron; $\mathrm{Pb}$, lead; MPN/100 mL, most probable number per 100 milliliters. Regression slopes and trend directions are zero when the slope is not different from zero at the 0.05 significance level; * indicates seasonal dependency (the slope and (or) intercept of growing (April through October) and non-growing (November through March) season data were different at the 0.05 significance level). +, positive trend direction; -, negative trend direction; NA, insufficient data for analysis; ND, undetermined value.]

\begin{tabular}{|c|c|c|c|c|c|c|c|c|c|}
\hline \multirow{3}{*}{$\begin{array}{l}\text { Constituent } \\
\mathrm{g} / \mathrm{L} \text { as } \mathrm{CaCO}_{3}\end{array}$} & \multicolumn{2}{|c|}{ 1989-93 WY } & \multicolumn{7}{|c|}{ 1976-93 WY } \\
\hline & \multicolumn{2}{|c|}{$\begin{array}{c}\text { Median } \\
\text { concentration }\end{array}$} & \multicolumn{2}{|c|}{$\begin{array}{c}\text { Median } \\
\text { concentration }\end{array}$} & \multicolumn{2}{|c|}{$\begin{array}{c}\text { Regression } \\
\text { slope of } \\
\text { concentration to } \\
\text { streamflow }\end{array}$} & \multirow{2}{*}{$\begin{array}{c}\begin{array}{c}\text { Regression } \\
\text { slope of } \\
\text { load to } \\
\text { streamflow }\end{array} \\
0.784\end{array}$} & \multirow{2}{*}{$\begin{array}{c}\text { Low- } \\
\text { flow } \\
\text { trend } \\
\text { direction } \\
\text { NA }\end{array}$} & \multirow{2}{*}{$\begin{array}{l}\text { High- } \\
\text { flow } \\
\text { trend } \\
\text { direction } \\
\text { NA }\end{array}$} \\
\hline & 56 & (74) & 56 & (95) & -0.216 & $*$ & & & \\
\hline Total hardness, $\mathrm{mg} / \mathrm{L}$ as $\mathrm{CaCO}_{3}$ & 83 & (73) & 85 & (95) & -.191 & & .809 & NA & NA \\
\hline Total organic carbon, $\mathrm{mg} / \mathrm{L}$ as $\mathrm{C}$ & 4.2 & (69) & 4.2 & $(88)$ & -.186 & $*$ & .816 & NA & NA \\
\hline Suspended sediment, $\mathrm{mg} / \mathrm{L}$ & ND & $(0)$ & 6 & (1) & ND & & ND & NA & NA \\
\hline Dissolved solids, $\mathrm{mg} / \mathrm{L}$ & 169 & (73) & 176 & (94) & -.153 & $*$ & .847 & NA & NA \\
\hline Dissolved sodium, $\mathrm{mg} / \mathrm{L}$ as $\mathrm{Na}$ & 25 & (74) & 26 & (95) & -.130 & $*$ & .870 & NA & NA \\
\hline Dissolved chloride, $\mathrm{mg} / \mathrm{L}$ as $\mathrm{Cl}$ & 46 & (74) & 48 & (95) & -.152 & $*$ & .848 & NA & NA \\
\hline Dissolved oxygen, mg/L & 10.5 & $(72)$ & 10.5 & (93) & 0 & $*$ & 1.065 & NA & NA \\
\hline $\begin{array}{l}\text { Fraction of dissolved oxygen at } \\
\text { saturation, } \%\end{array}$ & 102 & $(70)$ & 101 & (91) & 0 & & ND & NA & NA \\
\hline Total phosphorus, $\mathrm{mg} / \mathrm{L}$ as $\mathrm{P}$ & .06 & (73) & .07 & (94) & 0 & & .980 & NA & NA \\
\hline Total nitrogen, $\mathrm{mg} / \mathrm{L}$ as $\mathrm{N}$ & 1.2 & (73) & 1.2 & (94) & 0 & & 1.022 & NA & NA \\
\hline Total nitrate plus nitrite, $\mathrm{mg} / \mathrm{L}$ as $\mathrm{N}$ & .60 & (73) & .60 & (95) & .348 & $*$ & 1.348 & NA & NA \\
\hline Total nitrite, $\mathrm{mg} / \mathrm{L}$ as $\mathrm{N}$ & .020 & (73) & .020 & (95) & 0 & & 1.015 & NA & NA \\
\hline $\begin{array}{l}\text { Total ammonia plus organic nitrogen, } \\
\mathrm{mg} / \mathrm{L} \text { as } \mathrm{N}\end{array}$ & .50 & (73) & .60 & (94) & -.153 & $*$ & .847 & NA & NA \\
\hline Total ammonia, $\mathrm{mg} / \mathrm{L}$ as $\mathrm{N}$ & .05 & $(61)$ & .05 & $(82)$ & 0 & & 1.206 & NA & NA \\
\hline Total boron, $\mu \mathrm{g} / \mathrm{L}$ as $\mathrm{B}$ & ND & $(0)$ & ND & $(0)$ & ND & & ND & NA & NA \\
\hline Total lead, $\mu \mathrm{g} / \mathrm{L}$ as $\mathrm{Pb}$ & ND & $(0)$ & ND & $(0)$ & ND & & ND & NA & NA \\
\hline Fecal coliform bacteria, MPN/100 ml & ND & $(0)$ & ND & $(0)$ & ND & & ND & NA & NA \\
\hline
\end{tabular}

Table 15b. 1993 AMNET impairment status in the vicinity of water-quality station 01388000, Ramapo River at Pompton Lakes, N.J.

[AMNET, Ambient Biomonitoring Network; WQ, water-quality. Upstream from WQ station is within 5 miles upstream from the WQ station; at WQ-station location is within 0.5 mile upstream or downstream from the WQ station; downstream from WQ station is within 5 miles downstream from the WQ station; ND, undetermined impairment status]

\begin{tabular}{lccc}
\hline & Upstream from WQ station & At WQ-station location & Downstream from WQ station \\
\hline AMNET station & AN0267 & None & None \\
Impairment status & Moderately impaired & ND & ND \\
\hline
\end{tabular}


Table 16a. Median concentrations, relations of concentration and load to streamflow, and directions of concentration trends for selected waterquality constituents at water-quality station 01388600, Pompton River at Packanack Lake, N.J.

[Number in parenthesis is the number of available data; WY, water years; mg/L, milligrams per liter; $\mathrm{CaCO}_{3}$, calcium carbonate; $\mathrm{C}$, carbon; $\mathrm{Na}$, sodium; $\mathrm{Cl}$, chloride; \%, percent; $\mathrm{P}$, phosphorus; $\mathrm{N}$, nitrogen; $\mu \mathrm{g} / \mathrm{L}$, micrograms per liter; $\mathrm{B}$, boron; $\mathrm{Pb}$, lead; MPN/100 mL, most probable number per 100 milliliters. Regression slopes and trend directions are zero when the slope is not different from zero at the 0.05 significance level; * indicates seasonal dependency (the slope and (or) intercept of growing (April through October) and non-growing (November through March) season data were different at the 0.05 significance level). +, positive trend direction; -, negative trend direction; NA, insufficient data for analysis; $\mathrm{ND}$, undetermined value.]

\begin{tabular}{|c|c|c|c|c|c|c|c|c|c|}
\hline \multirow{3}{*}{$\begin{array}{c}\text { Constituent } \\
\text { Alkalinity, } \mathrm{mg} / \mathrm{L} \text { as } \mathrm{CaCO}_{3}\end{array}$} & \multicolumn{2}{|c|}{ 1989-93 WY } & \multicolumn{7}{|c|}{ 1976-93 WY } \\
\hline & \multicolumn{2}{|c|}{$\begin{array}{c}\text { Median } \\
\text { concentration }\end{array}$} & \multicolumn{2}{|c|}{$\begin{array}{l}\text { Median } \\
\text { concentration }\end{array}$} & \multicolumn{2}{|c|}{$\begin{array}{l}\text { Regression } \\
\text { slope of } \\
\text { concentration to } \\
\text { streamflow }\end{array}$} & \multirow{2}{*}{$\begin{array}{c}\begin{array}{c}\text { Regression } \\
\text { slope of } \\
\text { slope to } \\
\text { streamflow }\end{array} \\
0.797\end{array}$} & \multirow{2}{*}{$\begin{array}{c}\text { Low- } \\
\text { flow } \\
\text { trend } \\
\text { direction } \\
\text { NA }\end{array}$} & \multirow{2}{*}{$\begin{array}{c}\text { High- } \\
\text { flow } \\
\text { trend } \\
\text { direction } \\
\text { NA }\end{array}$} \\
\hline & 52 & (74) & 54 & $(133)$ & -0.203 & & & & \\
\hline Total hardness, $\mathrm{mg} / \mathrm{L}$ as $\mathrm{CaCO}_{3}$ & 80 & (75) & 81 & $(146)$ & -.174 & & .826 & NA & NA \\
\hline Total organic carbon, $\mathrm{mg} / \mathrm{L}$ as $\mathrm{C}$ & 3.6 & $(65)$ & 3.8 & $(132)$ & -.085 & $*$ & .914 & NA & NA \\
\hline Suspended sediment, $\mathrm{mg} / \mathrm{L}$ & 8 & (10) & 7 & (18) & 0 & & 1.331 & NA & NA \\
\hline Dissolved solids, $\mathrm{mg} / \mathrm{L}$ & 163 & (74) & 166 & (144) & -.156 & $*$ & .844 & NA & NA \\
\hline Dissolved sodium, $\mathrm{mg} / \mathrm{L}$ as $\mathrm{Na}$ & 23 & $(75)$ & 22 & $(146)$ & -.116 & $*$ & .884 & NA & NA \\
\hline Dissolved chloride, $\mathrm{mg} / \mathrm{L}$ as $\mathrm{Cl}$ & 39 & $(75)$ & 38 & $(146)$ & -.115 & $*$ & .885 & NA & NA \\
\hline Dissolved oxygen, mg/L & 10.6 & (74) & 9.8 & $(145)$ & .125 & $*$ & 1.125 & NA & NA \\
\hline $\begin{array}{l}\text { Fraction of dissolved oxygen at } \\
\text { saturation, } \%\end{array}$ & 104 & (73) & 100 & $(142)$ & .068 & $*$ & ND & NA & NA \\
\hline Total phosphorus, $\mathrm{mg} / \mathrm{L}$ as $\mathrm{P}$ & .07 & (73) & .08 & $(118)$ & -.268 & $*$ & .732 & NA & NA \\
\hline Total nitrogen, $\mathrm{mg} / \mathrm{L}$ as $\mathrm{N}$ & 1.4 & (73) & 1.6 & $(141)$ & -.220 & & .780 & NA & NA \\
\hline Total nitrate plus nitrite, $\mathrm{mg} / \mathrm{L}$ as $\mathrm{N}$ & .80 & (74) & .86 & $(142)$ & -.236 & $*$ & .764 & NA & NA \\
\hline Total nitrite, $\mathrm{mg} / \mathrm{L}$ as $\mathrm{N}$ & .020 & (74) & .02 & $(125)$ & -.398 & $*$ & .602 & NA & NA \\
\hline $\begin{array}{l}\text { Total ammonia plus organic nitrogen, } \\
\mathrm{mg} / \mathrm{L} \text { as } \mathrm{N}\end{array}$ & .50 & (73) & .70 & (144) & -.204 & $*$ & .796 & NA & NA \\
\hline Total ammonia, $\mathrm{mg} / \mathrm{L}$ as $\mathrm{N}$ & .11 & $(61)$ & .19 & $(129)$ & -.346 & & .654 & NA & NA \\
\hline Total boron, $\mu \mathrm{g} / \mathrm{L}$ as $\mathrm{B}$ & 40 & (7) & 50 & $(21)$ & -.314 & & .686 & NA & NA \\
\hline Total lead, $\mu \mathrm{g} / \mathrm{L}$ as $\mathrm{Pb}$ & 4 & (7) & 6 & (21) & 0 & & .964 & NA & NA \\
\hline Fecal coliform bacteria, MPN/100 ml & 320 & (23) & 230 & $(80)$ & 0 & & ND & NA & NA \\
\hline
\end{tabular}

Table 16b. 1993 AMNET impairment status in the vicinity of water-quality station 01388600, Pompton River at Packanack Lake, N.J.

[AMNET, Ambient Biomonitoring Network; WQ, water-quality. Upstream from WQ station is within 5 miles upstream from the WQ station; at WQ-station location is within 0.5 mile upstream or downstream from the WQ station; downstream from WQ station is within 5 miles downstream from the WQ station; ND, undetermined impairment status]

\begin{tabular}{lccc}
\hline & Upstream from WQ station & At WQ-station location & Downstream from WQ station \\
\hline AMNET station & None & AN0268 & None \\
Impairment status & ND & Moderately impaired & ND \\
\hline
\end{tabular}




\section{Lower Passaic River}

Three water-quality stations are located on the lower Passaic River-stations 01389005 below Pompton River at Two Bridges, 01389500 at Little Falls, and 01389880 at Route 46 at Elmwood Park. The 5-year and period-of-record medians at each station differ only slightly for all constituents (tables 17a, 18a, and 19a). The greatest differences are in BACT at station 01389500 and NH4 at station 01389880 . Station 01389500 has the highest 5 -year median for B of all 19 stations. Station 01389880 has the highest 5-year medians for PB and BACT, and the highest period-of-record medians for B, PB, and BACT for all 19 stations. The regression slope of concentration to streamflow shows seasonal dependency for TOC, DS, NA, CL, DO, FDO, TP, and NO2 at station 01389005; for HARD, TOC, SS, DS, NA, CL, DO, and all nutrient species at station 01389500; and for SS, DS, NA, DO, TP, TN, TAON, and NH4 at station 01389880. In the downstream direction (stations 01389005 to 01389500 to 01389880 ), the regression slopes of load to streamflow decrease for PB; increase for DS, NA, CL, DO, TP, TN, NO32, and NH4; and remain stable or unchanged for ALK, HARD, TOC, SS, NO2, and TAON.

Insufficient data are available for all constituents at stations 01389005 and 01389880 to determine trends in concentrations during low flows. At station 01389500, trends in concentrations during low flows are positive for CL and FDO; negative for TAON; and insignificant for HARD, DS, NA, DO, and TN. Insufficient data are available for all other constituents to determine trends in concentrations during low flows. Insufficient data are available for all constituents at station 01389005 to determine trends in concentrations during high flows. At station 01389500 , trends in concentrations during high flows are negative for SS and insignificant for HARD, DS, NA, CL, DO, FDO, TN, and TAON. Insufficient data are available for all other constituents to determine trends in concentrations during high flows. At station 01389880, trends in concentrations during high flows are insignificant for DO, TN, NO32, TAON, and NH4. Insufficient data are available for all other constituents to determine trends in concentrations during high flows.

The AMNET impairment status downstream from station 01389005 is moderately impaired (table 17b). The AMNET impairment status at station 01389500 is moderately impaired (table 18b).

\section{$\underline{\text { Saddle River }}$}

For the one station on the Saddle River, station 01391500 at Lodi, the 5-year and periodof-record medians differ only slightly (table 20a). The NH4 medians differ the most. TAON has the highest period-of-record median, and the other five nutrients have the highest 5-year and period-of-record medians of all 19 surface-water-quality stations. The regression slopes of concentration to streamflow for HARD, TOC, DS, NA, CL, DO, FDO, NO2, TAON, NH4, and BACT show seasonal dependency. The regression slopes of load to streamflow are in the low range for SS, NA, TP, NO2, TAON, NH4, and B; in the moderate range for HARD, TOC, DS, CL, $\mathrm{TN}$, and NO32; and in the high range for ALK, DO, and PB. The trends in concentration during low flows are positive for CL and insignificant for HARD, TOC, DS, NA, DO, FDO, TP, NO32, $\mathrm{NH} 4$, and BACT. Insufficient data are available for all other constituents to determine 
Table 17a. Median concentrations, relations of concentration and load to streamflow, and directions of concentration trends for selected waterquality constituents at water-quality station 01389005, Passaic River below Pompton River, at Two Bridges, N.J.

[Number in parenthesis is the number of available data; WY, water years; $\mathrm{mg} / \mathrm{L}$, milligrams per liter; $\mathrm{CaCO}_{3}$, calcium carbonate; $\mathrm{C}$, carbon; $\mathrm{Na}$, sodium; $\mathrm{Cl}$, chloride; \%, percent; $\mathrm{P}$, phosphorus; $\mathrm{N}$, nitrogen; $\mu \mathrm{g} / \mathrm{L}$, micrograms per liter; $\mathrm{B}$, boron; $\mathrm{Pb}$, lead; MPN/100 mL, most probable number per 100 milliliters. Regression slopes and trend directions are zero when the slope is not different from zero at the 0.05 significance level; * indicates seasonal dependency (the slope and (or) intercept of growing (April through October) and non-growing (November through March) season data were different at the 0.05 significance level). +, positive trend direction; -, negative trend direction; NA, insufficient data for analysis; ND, undetermined value.]

\begin{tabular}{|c|c|c|c|c|c|c|c|c|c|}
\hline \multirow{3}{*}{$\begin{array}{c}\text { Constituent } \\
\text { Alkalinity, } \mathrm{mg} / \mathrm{L} \text { as } \mathrm{CaCO}_{3}\end{array}$} & \multicolumn{2}{|c|}{ 1989-93 WY } & \multicolumn{7}{|c|}{ 1976-93 WY } \\
\hline & \multicolumn{2}{|c|}{$\begin{array}{c}\text { Median } \\
\text { concentration }\end{array}$} & \multicolumn{2}{|c|}{$\begin{array}{c}\text { Median } \\
\text { concentration }\end{array}$} & \multicolumn{2}{|c|}{$\begin{array}{c}\text { Regression } \\
\text { slope of } \\
\text { concentration to } \\
\text { streamflow }\end{array}$} & \multirow{2}{*}{$\begin{array}{c}\begin{array}{c}\text { Regression } \\
\text { slope of } \\
\text { load to } \\
\text { streamflow }\end{array} \\
0.694\end{array}$} & \multirow{2}{*}{$\begin{array}{c}\begin{array}{c}\text { Low- } \\
\text { flow } \\
\text { trend } \\
\text { direction }\end{array} \\
\text { NA }\end{array}$} & \multirow{2}{*}{$\begin{array}{c}\text { High- } \\
\text { flow } \\
\text { trend } \\
\text { direction } \\
\text { NA }\end{array}$} \\
\hline & 60 & $(69)$ & 60 & $(86)$ & -0.306 & & & & \\
\hline Total hardness, $\mathrm{mg} / \mathrm{L}$ as $\mathrm{CaCO}_{3}$ & 98 & $(67)$ & 100 & $(84)$ & -.318 & & .682 & NA & NA \\
\hline Total organic carbon, $\mathrm{mg} / \mathrm{L}$ as $\mathrm{C}$ & 5.6 & $(63)$ & 5.6 & $(80)$ & 0 & * & .965 & NA & NA \\
\hline Suspended sediment, $\mathrm{mg} / \mathrm{L}$ & ND & $(0)$ & ND & $(0)$ & ND & & ND & NA & NA \\
\hline Dissolved solids, $\mathrm{mg} / \mathrm{L}$ & 211 & $(67)$ & 214 & $(84)$ & -.296 & $*$ & .704 & NA & NA \\
\hline Dissolved sodium, $\mathrm{mg} / \mathrm{L}$ as $\mathrm{Na}$ & 32 & $(68)$ & 32 & $(85)$ & -.312 & * & .688 & NA & NA \\
\hline Dissolved chloride, $\mathrm{mg} / \mathrm{L}$ as $\mathrm{Cl}$ & 54 & $(68)$ & 54 & $(85)$ & -.290 & * & .710 & NA & NA \\
\hline Dissolved oxygen, $\mathrm{mg} / \mathrm{L}$ & 8.2 & $(64)$ & 7.4 & $(81)$ & 0 & $*$ & 1.050 & NA & NA \\
\hline $\begin{array}{l}\text { Fraction of dissolved oxygen at } \\
\text { saturation, } \%\end{array}$ & 84 & $(62)$ & 79 & (79) & 0 & * & ND & NA & NA \\
\hline Total phosphorus, $\mathrm{mg} / \mathrm{L}$ as $\mathrm{P}$ & .33 & $(68)$ & .37 & $(85)$ & -.655 & * & .345 & NA & NA \\
\hline Total nitrogen, $\mathrm{mg} / \mathrm{L}$ as $\mathrm{N}$ & 2.8 & $(67)$ & 3.2 & $(84)$ & -.544 & & .456 & NA & NA \\
\hline Total nitrate plus nitrite, $\mathrm{mg} / \mathrm{L}$ as $\mathrm{N}$ & 2.00 & $(67)$ & 1.95 & $(84)$ & -.688 & & .312 & NA & NA \\
\hline Total nitrite, $\mathrm{mg} / \mathrm{L}$ as $\mathrm{N}$ & .030 & $(68)$ & .040 & $(85)$ & -.438 & $*$ & .561 & NA & NA \\
\hline $\begin{array}{l}\text { Total ammonia plus organic nitrogen, } \\
\mathrm{mg} / \mathrm{L} \text { as } \mathrm{N}\end{array}$ & .80 & $(68)$ & .90 & $(85)$ & -.238 & & .762 & NA & NA \\
\hline Total ammonia, $\mathrm{mg} / \mathrm{L}$ as $\mathrm{N}$ & .19 & $(56)$ & .25 & $(73)$ & 0 & & .764 & NA & NA \\
\hline Total boron, $\mu \mathrm{g} / \mathrm{L}$ as $\mathrm{B}$ & ND & $(0)$ & ND & $(0)$ & ND & & ND & NA & NA \\
\hline Total lead, $\mu \mathrm{g} / \mathrm{L}$ as $\mathrm{Pb}$ & ND & $(0)$ & ND & $(0)$ & ND & & ND & NA & NA \\
\hline Fecal coliform bacteria, MPN/100 mL & ND & $(0)$ & ND & $(0)$ & ND & & ND & NA & NA \\
\hline
\end{tabular}

Table 17b. 1993 AMNET impairment status in the vicinity of water-quality station 01389005, Passaic River below Pompton River, at Two Bridges, N.J.

[AMNET, Ambient Biomonitoring Network; WQ, water-quality. Upstream from WQ station is within 5 miles upstream from the WQ station; at WQ-station location is within 0.5 mile upstream or downstream from the WQ station; downstream from WQ station is within 5 miles downstream from the WQ station; ND, undetermined impairment status]

\begin{tabular}{lccc}
\hline & Upstream from WQ station & At WQ-station location & Downstream from WQ station \\
\hline AMNET station & None & None & AN0274 \\
Impairment status & ND & ND & Moderately impaired \\
\hline
\end{tabular}


Table 18a. Median concentrations, relations of concentration and load to streamflow, and directions of concentration trends for selected waterquality constituents at water-quality station 01389500, Passaic River at Little Falls, N.J.

[Number in parenthesis is the number of available data; WY, water years; mg/L, milligrams per liter; $\mathrm{CaCO}_{3}$, calcium carbonate; $\mathrm{C}$, carbon; $\mathrm{Na}$, sodium; Cl, chloride; \%, percent; $\mathrm{P}$, phosphorus; $\mathrm{N}$, nitrogen; $\mu \mathrm{g} / \mathrm{L}$, micrograms per liter; $\mathrm{B}$, boron; $\mathrm{Pb}$, lead; MPN/100 mL, most probable number per 100 milliliters. Regression slopes and trend directions are zero when the slope is not different from zero at the 0.05 significance level; * indicates seasonal dependency (the slope and (or) intercept of growing (April through October) and non-growing (November through March) season data were different at the 0.05 significance level). +, positive trend direction; -, negative trend direction; NA, insufficient data for analysis; $\mathrm{ND}$, undetermined value.]

\begin{tabular}{|c|c|c|c|c|c|c|c|c|c|}
\hline \multirow{3}{*}{$\begin{array}{c}\text { Constituent } \\
\text { Alkalinity, } \mathrm{mg} / \mathrm{L} \text { as } \mathrm{CaCO}_{3}\end{array}$} & \multicolumn{2}{|c|}{ 1989-93 WY } & \multicolumn{7}{|c|}{ 1976-93 WY } \\
\hline & \multicolumn{2}{|c|}{$\begin{array}{c}\text { Median } \\
\text { concentration }\end{array}$} & \multicolumn{2}{|c|}{$\begin{array}{c}\text { Median } \\
\text { concentration }\end{array}$} & \multicolumn{2}{|c|}{$\begin{array}{c}\text { Regression } \\
\text { slope of } \\
\text { concentration to } \\
\text { streamflow }\end{array}$} & \multirow{2}{*}{$\begin{array}{c}\begin{array}{c}\text { Regression } \\
\text { slope of } \\
\text { load to } \\
\text { streamflow }\end{array} \\
0.750\end{array}$} & \multirow{2}{*}{$\begin{array}{c}\begin{array}{c}\text { Low- } \\
\text { flow } \\
\text { trend } \\
\text { direction }\end{array} \\
\text { NA }\end{array}$} & \multirow{2}{*}{$\begin{array}{c}\begin{array}{c}\text { High- } \\
\text { flow } \\
\text { trend } \\
\text { direction }\end{array} \\
\text { NA }\end{array}$} \\
\hline & 59 & (73) & 57 & $(137)$ & -0.250 & & & & \\
\hline Total hardness, $\mathrm{mg} / \mathrm{L}$ as $\mathrm{CaCO}_{3}$ & 100 & (74) & 94 & $(160)$ & -.261 & $*$ & .739 & 0 & 0 \\
\hline Total organic carbon, $\mathrm{mg} / \mathrm{L}$ as $\mathrm{C}$ & 5.7 & $(67)$ & 5.8 & $(124)$ & 0 & $*$ & .976 & NA & NA \\
\hline Suspended sediment, $\mathrm{mg} / \mathrm{L}$ & 16 & (29) & 20 & $(101)$ & 0 & $*$ & 1.130 & NA & - \\
\hline Dissolved solids, mg/L & 213 & (74) & 203 & $(159)$ & -.246 & $*$ & .754 & 0 & 0 \\
\hline Dissolved sodium, $\mathrm{mg} / \mathrm{L}$ as $\mathrm{Na}$ & 32 & (74) & 30 & $(161)$ & -.271 & $*$ & .729 & 0 & 0 \\
\hline Dissolved chloride, $\mathrm{mg} / \mathrm{L}$ as $\mathrm{Cl}$ & 52 & (74) & 48 & $(161)$ & -.244 & $*$ & .755 & + & 0 \\
\hline Dissolved oxygen, $\mathrm{mg} / \mathrm{L}$ & 9.8 & (74) & 9.5 & $(162)$ & .082 & * & 1.082 & 0 & 0 \\
\hline $\begin{array}{l}\text { Fraction of dissolved oxygen at } \\
\text { saturation, } \%\end{array}$ & 100 & $(72)$ & 96 & $(159)$ & .033 & & ND & + & 0 \\
\hline Total phosphorus, $\mathrm{mg} / \mathrm{L}$ as $\mathrm{P}$ & .35 & $(71)$ & .38 & $(151)$ & -.478 & * & .522 & NA & NA \\
\hline Total nitrogen, $\mathrm{mg} / \mathrm{L}$ as $\mathrm{N}$ & 3.0 & $(71)$ & 3.2 & $(156)$ & -.435 & $*$ & .565 & 0 & 0 \\
\hline Total nitrate plus nitrite, $\mathrm{mg} / \mathrm{L}$ as $\mathrm{N}$ & 2.00 & (73) & 1.50 & $(158)$ & -.482 & * & .518 & NA & NA \\
\hline Total nitrite, $\mathrm{mg} / \mathrm{L}$ as $\mathrm{N}$ & .040 & (73) & .040 & $(108)$ & -.304 & $*$ & .695 & NA & NA \\
\hline $\begin{array}{l}\text { Total ammonia plus organic nitrogen, } \\
\mathrm{mg} / \mathrm{L} \text { as } \mathrm{N}\end{array}$ & .80 & $(71)$ & 1.20 & $(156)$ & -.302 & $*$ & .698 & - & 0 \\
\hline Total ammonia, $\mathrm{mg} / \mathrm{L}$ as $\mathrm{N}$ & .16 & $(60)$ & .37 & $(123)$ & -.319 & * & .681 & NA & NA \\
\hline Total boron, $\mu \mathrm{g} / \mathrm{L}$ as $\mathrm{B}$ & 200 & (1) & 125 & (4) & ND & & ND & NA & NA \\
\hline Total lead, $\mu \mathrm{g} / \mathrm{L}$ as $\mathrm{Pb}$ & 5 & (1) & 7 & (20) & 0 & & 1.156 & NA & NA \\
\hline Fecal coliform bacteria, MPN/100 ml & 130 & (9) & 310 & $(29)$ & 614 & & ND & NA & NA \\
\hline
\end{tabular}

Table 18b. 1993 AMNET impairment status in the vicinity of water-quality station 01389500, Passaic River at Little Falls, N.J.

[AMNET, Ambient Biomonitoring Network; WQ, water-quality. Upstream from WQ station is within 5 miles upstream from the WQ station; at WQ-station location is within 0.5 mile upstream or downstream from the WQ station; downstream from WQ station is within 5 miles downstream from the WQ station; ND, undetermined impairment status]

\begin{tabular}{lccc}
\hline & Upstream from WQ station & At WQ-station location & Downstream from WQ station \\
\hline AMNET station & None & AN0274 & None \\
Impairment status & ND & Moderately impaired & ND \\
\hline
\end{tabular}


Table 19a. Median concentrations, relations of concentration and load to streamflow, and directions of concentration trends for selected waterquality constituents at water-quality station 01389880, Passaic River at Route 46, at Elmwood Park, N.J.

[Number in parenthesis is the number of available data; WY, water years; $\mathrm{mg} / \mathrm{L}$, milligrams per liter; $\mathrm{CaCO}_{3}$, calcium carbonate; $\mathrm{C}$, carbon; $\mathrm{Na}$, sodium; $\mathrm{Cl}$, chloride; \%, percent; $\mathrm{P}$, phosphorus; $\mathrm{N}$, nitrogen; $\mu \mathrm{g} / \mathrm{L}$, micrograms per liter; $\mathrm{B}$, boron; $\mathrm{Pb}$, lead; MPN/100 mL, most probable number per 100 milliliters. Regression slopes and trend directions are zero when the slope is not different from zero at the 0.05 significance level; * indicates seasonal dependency (the slope and (or) intercept of growing (April through October) and non-growing (November through March) season data were different at the 0.05 significance level). +, positive trend direction; -, negative trend direction; NA, insufficient data for analysis; ND, undetermined value.]

\begin{tabular}{|c|c|c|c|c|c|c|c|c|c|}
\hline \multirow{3}{*}{$\begin{array}{l}\text { Constituent } \\
\mathrm{g} / \mathrm{L} \text { as } \mathrm{CaCO}_{3}\end{array}$} & \multicolumn{2}{|c|}{ 1989-93 WY } & \multicolumn{7}{|c|}{ 1976-93 WY } \\
\hline & \multicolumn{2}{|c|}{$\begin{array}{c}\text { Median } \\
\text { concentration }\end{array}$} & $\begin{array}{r}\text { Medi } \\
\text { concent }\end{array}$ & $\begin{array}{l}\text { ian } \\
\text { ration }\end{array}$ & \multicolumn{2}{|c|}{$\begin{array}{c}\text { Regression } \\
\text { slope of } \\
\text { concentration to } \\
\text { streamflow }\end{array}$} & \multirow{2}{*}{$\begin{array}{c}\begin{array}{c}\text { Regression } \\
\text { slope of } \\
\text { load to } \\
\text { streamflow }\end{array} \\
0.744\end{array}$} & \multirow{2}{*}{$\begin{array}{c}\begin{array}{c}\text { Low- } \\
\text { flow } \\
\text { trend } \\
\text { direction }\end{array} \\
\text { NA }\end{array}$} & \multirow{2}{*}{$\begin{array}{c}\begin{array}{c}\text { High- } \\
\text { flow } \\
\text { trend } \\
\text { direction }\end{array} \\
\text { NA }\end{array}$} \\
\hline & 85 & $(11)$ & 85 & $(11)$ & -0.256 & & & & \\
\hline Total hardness, $\mathrm{mg} / \mathrm{L}$ as $\mathrm{CaCO}_{3}$ & 120 & $(12)$ & 98 & $(40)$ & -.252 & & .747 & NA & NA \\
\hline Total organic carbon, $\mathrm{mg} / \mathrm{L}$ as $\mathrm{C}$ & 6.4 & $(11)$ & 7.1 & (89) & 0 & & .977 & NA & NA \\
\hline Suspended sediment, $\mathrm{mg} / \mathrm{L}$ & 16 & $(10)$ & 17 & $(45)$ & .269 & * & 1.268 & NA & NA \\
\hline Dissolved solids, mg/L & 276 & $(11)$ & 186 & (93) & -.268 & $*$ & .732 & NA & NA \\
\hline Dissolved sodium, $\mathrm{mg} / \mathrm{L}$ as $\mathrm{Na}$ & 44 & $(12)$ & 32 & $(40)$ & -.276 & * & .724 & NA & NA \\
\hline Dissolved chloride, $\mathrm{mg} / \mathrm{L}$ as $\mathrm{Cl}$ & 72 & (13) & 39 & $(58)$ & -.262 & & .738 & NA & NA \\
\hline Dissolved oxygen, $\mathrm{mg} / \mathrm{L}$ & 11.9 & $(21)$ & 9.9 & $(153)$ & .147 & * & 1.147 & NA & 0 \\
\hline $\begin{array}{l}\text { Fraction of dissolved oxygen at } \\
\text { saturation, } \%\end{array}$ & 91 & $(21)$ & 95 & $(151)$ & .061 & & ND & NA & NA \\
\hline Total phosphorus, $\mathrm{mg} / \mathrm{L}$ as $\mathrm{P}$ & .23 & $(21)$ & .37 & $(145)$ & -.255 & * & .745 & NA & NA \\
\hline Total nitrogen, $\mathrm{mg} / \mathrm{L}$ as $\mathrm{N}$ & 3.5 & $(21)$ & 3.0 & $(147)$ & -.339 & * & .661 & NA & 0 \\
\hline Total nitrate plus nitrite, $\mathrm{mg} / \mathrm{L}$ as $\mathrm{N}$ & 2.09 & $(21)$ & 1.48 & $(150)$ & -.420 & & .579 & NA & 0 \\
\hline Total nitrite, $\mathrm{mg} / \mathrm{L}$ as $\mathrm{N}$ & .044 & $(21)$ & .057 & $(50)$ & -.274 & & .726 & NA & NA \\
\hline $\begin{array}{l}\text { Total ammonia plus organic nitrogen, } \\
\mathrm{mg} / \mathrm{L} \text { as } \mathrm{N}\end{array}$ & 1.18 & $(21)$ & 1.50 & $(148)$ & -.246 & * & .754 & NA & 0 \\
\hline Total ammonia, $\mathrm{mg} / \mathrm{L}$ as $\mathrm{N}$ & .10 & $(21)$ & .44 & $(147)$ & 0 & $*$ & .987 & NA & 0 \\
\hline Total boron, $\mu \mathrm{g} / \mathrm{L}$ as $\mathrm{B}$ & 170 & (1) & 170 & (1) & ND & & ND & NA & NA \\
\hline Total lead, $\mu \mathrm{g} / \mathrm{L}$ as $\mathrm{Pb}$ & 11 & (3) & 18 & $(66)$ & 0 & & 1.999 & NA & NA \\
\hline Fecal coliform bacteria, MPN/100 ml & 2000 & $(21)$ & 3500 & $(50)$ & 0 & & ND & NA & NA \\
\hline
\end{tabular}

Table 19b. 1993 AMNET impairment status in the vicinity of water-quality station 01389880, Passaic River at Route 46, at Elmwood Park, N.J.

[AMNET, Ambient Biomonitoring Network; WQ, water-quality. Upstream from WQ station is within 5 miles upstream from the WQ station; at WQ-station location is within 0.5 mile upstream or downstream from the WQ station; downstream from WQ station is within 5 miles downstream from the WQ station; ND, undetermined impairment status]

\begin{tabular}{lccc}
\hline & Upstream from WQ station & At WQ-station location & Downstream from WQ station \\
\hline AMNET station & None & None & None \\
Impairment status & ND & ND & ND \\
\hline
\end{tabular}


Table 20a. Median concentrations, relations of concentration and load to streamflow, and directions of concentration trends for selected waterquality constituents at water-quality station 01391500, Saddle River at Lodi, N.J.

[Number in parenthesis is the number of available data; WY, water years; $\mathrm{mg} / \mathrm{L}$, milligrams per liter; $\mathrm{CaCO}_{3}$, calcium carbonate; $\mathrm{C}$, carbon; $\mathrm{Na}$, sodium; $\mathrm{Cl}$, chloride; \%, percent; $\mathrm{P}$, phosphorus; $\mathrm{N}$, nitrogen; $\mu \mathrm{g} / \mathrm{L}$, micrograms per liter; $\mathrm{B}$, boron; $\mathrm{Pb}$, lead; MPN/100 mL, most probable number per 100 milliliters. Regression slopes and trend directions are zero when the slope is not different from zero at the 0.05 significance level; * indicates seasonal dependency (the slope and (or) intercept of growing (April through October) and non-growing (November through March) season data were different at the 0.05 significance level). +, positive trend direction; -, negative trend direction; NA, insufficient data for analysis; ND, undetermined value.]

\begin{tabular}{|c|c|c|c|c|c|c|c|c|c|}
\hline \multirow{3}{*}{$\begin{array}{c}\text { Constituent } \\
\text { Alkalinity, } \mathrm{mg} / \mathrm{L} \text { as } \mathrm{CaCO}_{3}\end{array}$} & \multicolumn{2}{|c|}{ 1989-93 WY } & \multicolumn{7}{|c|}{ 1976-93 WY } \\
\hline & \multicolumn{2}{|c|}{$\begin{array}{c}\text { Median } \\
\text { concentration }\end{array}$} & \multicolumn{2}{|c|}{$\begin{array}{c}\text { Median } \\
\text { concentration }\end{array}$} & \multicolumn{2}{|c|}{$\begin{array}{l}\text { Regression } \\
\text { slope of } \\
\text { concentration to } \\
\text { streamflow }\end{array}$} & \multirow{2}{*}{$\begin{array}{c}\begin{array}{c}\text { Regression } \\
\text { slope of } \\
\text { load to } \\
\text { streamflow }\end{array} \\
0.877\end{array}$} & \multirow{2}{*}{$\begin{array}{c}\begin{array}{c}\text { Low- } \\
\text { flow } \\
\text { trend } \\
\text { direction }\end{array} \\
\text { NA }\end{array}$} & \multirow{2}{*}{$\begin{array}{c}\begin{array}{c}\text { High- } \\
\text { flow } \\
\text { trend } \\
\text { direction }\end{array} \\
\text { NA }\end{array}$} \\
\hline & 121 & $(27)$ & 117 & $(75)$ & -0.122 & & & & \\
\hline Total hardness, $\mathrm{mg} / \mathrm{L}$ as $\mathrm{CaCO}_{3}$ & 180 & $(27)$ & 180 & $(111)$ & -.272 & $*$ & .728 & 0 & + \\
\hline Total organic carbon, $\mathrm{mg} / \mathrm{L}$ as $\mathrm{C}$ & 5.0 & $(26)$ & 5.7 & $(108)$ & 0 & * & .972 & 0 & NA \\
\hline Suspended sediment, $\mathrm{mg} / \mathrm{L}$ & 7 & (9) & 8 & $(24)$ & 0 & & .967 & NA & NA \\
\hline Dissolved solids, $\mathrm{mg} / \mathrm{L}$ & 333 & $(26)$ & 337 & $(110)$ & -.277 & $*$ & .723 & 0 & 0 \\
\hline Dissolved sodium, $\mathrm{mg} / \mathrm{L}$ as $\mathrm{Na}$ & 44 & (27) & 42 & (111) & -.314 & * & .686 & 0 & + \\
\hline Dissolved chloride, $\mathrm{mg} / \mathrm{L}$ as $\mathrm{Cl}$ & 80 & $(27)$ & 69 & (111) & -.285 & * & .715 & + & + \\
\hline Dissolved oxygen, $\mathrm{mg} / \mathrm{L}$ & 9.0 & $(26)$ & 7.5 & $(109)$ & .193 & $*$ & 1.193 & 0 & 0 \\
\hline $\begin{array}{l}\text { Fraction of dissolved oxygen at } \\
\text { saturation, } \%\end{array}$ & 87 & $(24)$ & 76 & $(107)$ & .150 & * & ND & 0 & 0 \\
\hline Total phosphorus, $\mathrm{mg} / \mathrm{L}$ as $\mathrm{P}$ & .43 & $(25)$ & .78 & (104) & -.542 & & .458 & 0 & 0 \\
\hline Total nitrogen, $\mathrm{mg} / \mathrm{L}$ as $\mathrm{N}$ & 5.2 & $(26)$ & 5.8 & (98) & -.364 & & .635 & NA & NA \\
\hline Total nitrate plus nitrite, $\mathrm{mg} / \mathrm{L}$ as $\mathrm{N}$ & 3.70 & $(27)$ & 3.19 & $(102)$ & -.356 & & 643 & 0 & NA \\
\hline Total nitrite, $\mathrm{mg} / \mathrm{L}$ as $\mathrm{N}$ & .165 & $(27)$ & .219 & $(81)$ & -.879 & $*$ & 0 & NA & NA \\
\hline $\begin{array}{l}\text { Total ammonia plus organic nitrogen, } \\
\mathrm{mg} / \mathrm{L} \text { as } \mathrm{N}\end{array}$ & 1.16 & $(26)$ & 2.10 & $(107)$ & -.397 & $*$ & .603 & NA & - \\
\hline Total ammonia, $\mathrm{mg} / \mathrm{L}$ as $\mathrm{N}$ & .45 & $(27)$ & 1.29 & $(98)$ & -.749 & $*$ & .251 & 0 & NA \\
\hline Total boron, $\mu \mathrm{g} / \mathrm{L}$ as $\mathrm{B}$ & 80 & (4) & 110 & $(17)$ & -.497 & & .503 & NA & NA \\
\hline Total lead, $\mu \mathrm{g} / \mathrm{L}$ as $\mathrm{Pb}$ & 4 & (4) & 6 & $(20)$ & .661 & & 1.661 & NA & NA \\
\hline Fecal coliform bacteria, MPN/100 ml & 1600 & $(25)$ & 1600 & $(107)$ & 0 & $*$ & ND & 0 & 0 \\
\hline
\end{tabular}

Table 20b. 1993 AMNET impairment status in the vicinity of water-quality station 01391500, Saddle River at Lodi, N.J.

[AMNET, Ambient Biomonitoring Network; WQ, water-quality. Upstream from WQ station is within 5 miles upstream from the WQ station; at WQ-station location is within 0.5 mile upstream or downstream from the WQ station; downstream from WQ station is within 5 miles downstream from the WQ station; ND, undetermined impairment status]

\begin{tabular}{lccc}
\hline & Upstream from WQ station & At WQ-station location & Downstream from WQ station \\
\hline AMNET station & AN0290 & None & AN0291 \\
Impairment status & Moderately impaired & ND & Severely impaired \\
\hline
\end{tabular}


trends for low flow. The trends in concentrations during high flows are positive for HARD, NA, and CL; negative for TAON; and insignificant for DS, DO, FDO, TP, and BACT. Insufficient data are available for all other constituents to determine trends in concentrations during high flows.

The AMNET impairment status upstream from station 01391500 is moderately impaired, and the downstream status is severely impaired (table 20b).

\section{Elizabeth River}

For the one station on the Elizabeth River, station 01393450 at Ursino Lake at Elizabeth, the 5-year and period-of-record medians differ slightly (table 21a). ALK and NA have the highest 5-year median of all 19 stations. HARD and CL have the highest 5-year and period-of-record medians of all 19 stations. The regression slope of concentration to streamflow shows seasonal dependency for HARD, DS, NA, CL, DO, TN, NO32, and BACT. The regression slope of load to streamflow is in the low range for ALK, HARD, DS, NA, CL, and DO; in the moderate range for NO32 and B; and in the high range for TOC, SS, TP, TN, NO2, TAON, NH4, and PB.

Insufficient data are available for all constituents to determine trends in concentrations during low and high flows. The AMNET impairment status at station 01393450 is moderately impaired, and downstream is severely impaired (table 21b).

\section{Rahway River}

Two water-quality stations are located on the Rahway River-stations 01394500 near Springfield and 01395000 at Rahway. The 5-year and period-of-record medians at both stations differ only slightly for all constituents (tables 22a and 23a). Regression slopes of concentration to streamflow show seasonal dependency for TOC, SS, DS, NA, CL, DO, FDO, TP, NO32, NO2, TAON, NH4, and BACT at station 01394500 and for HARD, TOC, DS, NA, CL, DO, FDO, TP, NO32, NO2, TAON, and BACT at station 01395000. In the downstream direction (stations 01394500 to 01395000 ), the regression slopes of load to streamflow decrease for DO and B; increase for ALK, HARD, TP, NO32, and NH4; and remains stable for TOC, SS, DS, NA, CL, TN, NO2, TAON, and PB. Insufficient data are available for all constituents to determine trends in concentrations during low and high flows.

The AMNET impairment status upstream an downstream from station 01394500 is moderately impaired (table 22b). The AMNET impairment status upstream and at station 01395000 is moderately impaired (table $23 b$ ).

\section{Analysis of Relations by Constituent}

Schematics of the trends in concentrations during low and high flows and the values of the slopes of load to streamflow are shown for each constituent. Schematics depicting the slopes of load to streamflow are presented for each constituent except dissolved-oxygen saturation and fecal coliform bacteria because loads were not calculated for these two constituents. The 01 prefix and any extraneous ending zeros have been removed from station numbers on the schematics and in the text that follows. Schematics are not drawn to scale. Only results from 
Table 21a. Median concentrations, relations of concentration and load to streamflow, and directions of concentration trends for selected waterquality constituents at water-quality station 01393450, Elizabeth River at Ursino Lake, at Elizabeth, N.J.

[Number in parenthesis is the number of available data; WY, water years; mg/L, milligrams per liter; $\mathrm{CaCO}_{3}$, calcium carbonate; $\mathrm{C}$, carbon; $\mathrm{Na}$, sodium; $\mathrm{Cl}$, chloride; \%, percent; $\mathrm{P}$, phosphorus; $\mathrm{N}$, nitrogen; $\mu \mathrm{g} / \mathrm{L}$, micrograms per liter; $\mathrm{B}$, boron; $\mathrm{Pb}$, lead; MPN/100 mL, most probable number per 100 milliliters. Regression slopes and trend directions are zero when the slope is not different from zero at the 0.05 significance level; * indicates seasonal dependency (the slope and (or) intercept of growing (April through October) and non-growing (November through March) season data were different at the 0.05 significance level). +, positive trend direction; -, negative trend direction; NA, insufficient data for analysis; $\mathrm{ND}$, undetermined value.]

\begin{tabular}{|c|c|c|c|c|c|c|c|c|c|}
\hline \multirow{3}{*}{$\begin{array}{c}\text { Constituent } \\
\mathrm{ag} / \mathrm{L} \text { as } \mathrm{CaCO}_{3}\end{array}$} & \multicolumn{2}{|c|}{ 1989-93 WY } & \multicolumn{7}{|c|}{ 1976-93 WY } \\
\hline & \multicolumn{2}{|c|}{$\begin{array}{c}\text { Median } \\
\text { concentration }\end{array}$} & \multicolumn{2}{|c|}{$\begin{array}{l}\text { Median } \\
\text { concentration }\end{array}$} & \multicolumn{2}{|c|}{$\begin{array}{c}\text { Regression } \\
\text { slope of } \\
\text { concentration to } \\
\text { streamflow }\end{array}$} & \multirow{2}{*}{$\begin{array}{c}\begin{array}{c}\text { Regression } \\
\text { slope of } \\
\text { load to } \\
\text { streamflow }\end{array} \\
0.629\end{array}$} & \multirow{2}{*}{$\begin{array}{c}\begin{array}{c}\text { Low- } \\
\text { flow } \\
\text { trend } \\
\text { direction }\end{array} \\
\text { NA }\end{array}$} & \multirow{2}{*}{$\begin{array}{c}\begin{array}{c}\text { High- } \\
\text { flow } \\
\text { trend } \\
\text { direction }\end{array} \\
\text { NA }\end{array}$} \\
\hline & 132 & $(26)$ & 113 & $(72)$ & -0.371 & & & & \\
\hline Total hardness, $\mathrm{mg} / \mathrm{L}$ as $\mathrm{CaCO}_{3}$ & 220 & $(27)$ & 195 & $(84)$ & -.439 & $*$ & .561 & NA & NA \\
\hline Total organic carbon, $\mathrm{mg} / \mathrm{L}$ as $\mathrm{C}$ & 4.5 & $(24)$ & 5.3 & $(80)$ & .219 & & 1.219 & NA & NA \\
\hline Suspended sediment, $\mathrm{mg} / \mathrm{L}$ & 4 & $(10)$ & 5 & $(23)$ & .915 & & 1.915 & NA & NA \\
\hline Dissolved solids, $\mathrm{mg} / \mathrm{L}$ & 404 & $(26)$ & 365 & $(83)$ & -.380 & $*$ & 619 & NA & NA \\
\hline Dissolved sodium, $\mathrm{mg} / \mathrm{L}$ as $\mathrm{Na}$ & 46 & $(27)$ & 40 & $(84)$ & -.299 & $*$ & .700 & NA & NA \\
\hline Dissolved chloride, $\mathrm{mg} / \mathrm{L}$ as $\mathrm{Cl}$ & 97 & $(27)$ & 78 & $(84)$ & -.416 & $*$ & .584 & NA & NA \\
\hline Dissolved oxygen, $\mathrm{mg} / \mathrm{L}$ & 9.7 & $(25)$ & 10.0 & $(80)$ & -.098 & $*$ & .902 & NA & NA \\
\hline $\begin{array}{l}\text { Fraction of dissolved oxygen at } \\
\text { saturation, } \%\end{array}$ & 94 & (23) & 93 & (77) & -.125 & & ND & NA & NA \\
\hline Total phosphorus, $\mathrm{mg} / \mathrm{L}$ as $\mathrm{P}$ & .09 & $(27)$ & .10 & $(57)$ & 0 & & 1.168 & NA & NA \\
\hline Total nitrogen, $\mathrm{mg} / \mathrm{L}$ as $\mathrm{N}$ & 2.2 & $(27)$ & 2.2 & $(81)$ & 0 & $*$ & .979 & NA & NA \\
\hline Total nitrate plus nitrite, $\mathrm{mg} / \mathrm{L}$ as $\mathrm{N}$ & 1.65 & $(27)$ & 1.46 & $(82)$ & 0 & * & .997 & NA & NA \\
\hline Total nitrite, $\mathrm{mg} / \mathrm{L}$ as $\mathrm{N}$ & .049 & $(27)$ & .048 & $(64)$ & 0 & & 1.022 & NA & NA \\
\hline $\begin{array}{l}\text { Total ammonia plus organic nitrogen, } \\
\mathrm{mg} / \mathrm{L} \text { as } \mathrm{N}\end{array}$ & .62 & $(27)$ & .74 & $(82)$ & .123 & & 1.123 & NA & NA \\
\hline Total ammonia, $\mathrm{mg} / \mathrm{L}$ as $\mathrm{N}$ & .10 & $(27)$ & .13 & $(78)$ & 0 & & 1.088 & NA & NA \\
\hline Total boron, $\mu \mathrm{g} / \mathrm{L}$ as $\mathrm{B}$ & 80 & (4) & 100 & (14) & -.372 & & .628 & NA & NA \\
\hline Total lead, $\mu \mathrm{g} / \mathrm{L}$ as $\mathrm{Pb}$ & 3 & (4) & 6 & $(15)$ & .872 & & 1.872 & NA & NA \\
\hline Fecal coliform bacteria, MPN/100 ml & 1700 & $(23)$ & $>2400$ & $(72)$ & .795 & * & ND & NA & NA \\
\hline
\end{tabular}

Table 21b. 1993 AMNET impairment status in the vicinity of water-quality station 01393450, Elizabeth River at Ursino Lake, at Elizabeth, N.J.

[AMNET, Ambient Biomonitoring Network; WQ, water-quality. Upstream from WQ station is within 5 miles upstream from the WQ station; at WQ-station location is within 0.5 mile upstream or downstream from the WQ station; downstream from WQ station is within 5 miles downstream from the WQ station; ND, undetermined impairment status]

\begin{tabular}{lccc}
\hline & Upstream from WQ station & At WQ-station location & Downstream from WQ station \\
\hline AMNET station & None & AN0202 & AN0204 \\
Impairment status & ND & Moderately impaired & Severely impaired \\
\hline
\end{tabular}


Table 22a. Median concentrations, relations of concentration and load to streamflow, and directions of concentration trends for selected waterquality constituents at water-quality station 01394500, Rahway River near Springfield, N.J.

[Number in parenthesis is the number of available data; WY, water years; $\mathrm{mg} / \mathrm{L}$, milligrams per liter; $\mathrm{CaCO}_{3}$, calcium carbonate; $\mathrm{C}$, carbon; $\mathrm{Na}$, sodium; $\mathrm{Cl}$, chloride; \%, percent; $\mathrm{P}$, phosphorus; $\mathrm{N}$, nitrogen; $\mu \mathrm{g} / \mathrm{L}$, micrograms per liter; $\mathrm{B}$, boron; $\mathrm{Pb}$, lead; MPN/100 mL, most probable number per 100 milliliters. Regression slopes and trend directions are zero when the slope is not different from zero at the 0.05 significance level; * indicates seasonal dependency (the slope and (or) intercept of growing (April through October) and non-growing (November through March) season data were different at the 0.05 significance level). +, positive trend direction; -, negative trend direction; NA, insufficient data for analysis; ND, undetermined value.]

\begin{tabular}{|c|c|c|c|c|c|c|c|c|c|}
\hline \multirow{3}{*}{$\begin{array}{c}\text { Constituent } \\
\text { Alkalinity, } \mathrm{mg} / \mathrm{L} \text { as } \mathrm{CaCO}_{3}\end{array}$} & \multicolumn{2}{|c|}{ 1989-93 WY } & \multicolumn{7}{|c|}{ 1976-93 WY } \\
\hline & \multicolumn{2}{|c|}{$\begin{array}{l}\text { Median } \\
\text { concentration }\end{array}$} & \multicolumn{2}{|c|}{$\begin{array}{c}\text { Median } \\
\text { concentration }\end{array}$} & \multicolumn{2}{|c|}{$\begin{array}{c}\text { Regression } \\
\text { slope of } \\
\text { concentration to } \\
\text { streamflow }\end{array}$} & \multirow{2}{*}{$\begin{array}{c}\begin{array}{c}\text { Regression } \\
\text { slope of } \\
\text { load to } \\
\text { streamflow }\end{array} \\
0.744\end{array}$} & \multirow{2}{*}{$\begin{array}{c}\begin{array}{c}\text { Low- } \\
\text { flow } \\
\text { trend } \\
\text { direction }\end{array} \\
\text { NA }\end{array}$} & \multirow{2}{*}{$\begin{array}{c}\text { High- } \\
\text { flow } \\
\text { trend } \\
\text { direction } \\
\text { NA }\end{array}$} \\
\hline & 106 & $(27)$ & 93 & (73) & -0.256 & & & & \\
\hline Total hardness, $\mathrm{mg} / \mathrm{L}$ as $\mathrm{CaCO}_{3}$ & 180 & $(27)$ & 160 & $(86)$ & -.230 & & .770 & NA & NA \\
\hline Total organic carbon, $\mathrm{mg} / \mathrm{L}$ as $\mathrm{C}$ & 4.0 & $(27)$ & 4.1 & $(85)$ & .100 & * & 1.100 & NA & NA \\
\hline Suspended sediment, $\mathrm{mg} / \mathrm{L}$ & 3 & $(11)$ & 4 & (26) & 0 & * & 1.486 & NA & NA \\
\hline Dissolved solids, $\mathrm{mg} / \mathrm{L}$ & 314 & (26) & 302 & $(83)$ & 0 & $*$ & .928 & NA & NA \\
\hline Dissolved sodium, $\mathrm{mg} / \mathrm{L}$ as $\mathrm{Na}$ & 33 & $(27)$ & 31 & $(86)$ & 0 & * & 1.107 & NA & NA \\
\hline Dissolved chloride, $\mathrm{mg} / \mathrm{L}$ as $\mathrm{Cl}$ & 75 & $(27)$ & 65 & $(86)$ & 0 & $*$ & 1.064 & NA & NA \\
\hline Dissolved oxygen, $\mathrm{mg} / \mathrm{L}$ & 8.7 & $(25)$ & 7.6 & $(84)$ & .132 & * & 1.132 & NA & NA \\
\hline $\begin{array}{l}\text { Fraction of dissolved oxygen at } \\
\text { saturation, } \%\end{array}$ & 82 & $(24)$ & 80 & $(81)$ & .103 & * & ND & NA & NA \\
\hline Total phosphorus, $\mathrm{mg} / \mathrm{L}$ as $\mathrm{P}$ & .07 & $(25)$ & .08 & $(57)$ & 0 & * & .934 & NA & NA \\
\hline Total nitrogen, $\mathrm{mg} / \mathrm{L}$ as $\mathrm{N}$ & 1.9 & $(27)$ & 1.9 & $(83)$ & 0 & & .966 & NA & NA \\
\hline Total nitrate plus nitrite, $\mathrm{mg} / \mathrm{L}$ as $\mathrm{N}$ & 1.37 & $(27)$ & 1.30 & $(85)$ & 0 & * & .962 & NA & NA \\
\hline Total nitrite, $\mathrm{mg} / \mathrm{L}$ as $\mathrm{N}$ & .024 & $(27)$ & .028 & $(67)$ & 0 & * & .853 & NA & NA \\
\hline $\begin{array}{l}\text { Total ammonia plus organic nitrogen, } \\
\mathrm{mg} / \mathrm{L} \text { as } \mathrm{N}\end{array}$ & .53 & $(27)$ & .60 & $(83)$ & 0 & * & 1.002 & NA & NA \\
\hline Total ammonia, $\mathrm{mg} / \mathrm{L}$ as $\mathrm{N}$ & .09 & $(27)$ & .11 & $(81)$ & 0 & * & .956 & NA & NA \\
\hline Total boron, $\mu \mathrm{g} / \mathrm{L}$ as $\mathrm{B}$ & 70 & $(5)$ & 70 & $(19)$ & 0 & & 1.064 & NA & NA \\
\hline Total lead, $\mu \mathrm{g} / \mathrm{L}$ as $\mathrm{Pb}$ & 6 & $(5)$ & 6 & $(20)$ & 0 & & 1.187 & NA & NA \\
\hline Fecal coliform bacteria, MPN/100 ml & 1300 & $(25)$ & 1300 & $(83)$ & .576 & * & ND & NA & NA \\
\hline
\end{tabular}

Table 22b. 1993 AMNET impairment status in the vicinity of water-quality station 01394500, Rahway River near Springfield, N.J.

[AMNET, Ambient Biomonitoring Network; WQ, water-quality. Upstream from WQ station is within 5 miles upstream from the WQ station; at WQ-station location is within 0.5 mile upstream or downstream from the WQ station; downstream from WQ station is within 5 miles downstream from the WQ station; ND, undetermined impairment status]

\begin{tabular}{lccc}
\hline & Upstream from WQ station & At WQ-station location & Downstream from WQ station \\
\hline AMNET station & AN0193 & None & AN0194 \\
Impairment status & Moderately impaired & ND & Moderately impaired \\
\hline
\end{tabular}


Table 23a. Median concentrations, relations of concentration and load to streamflow, and directions of concentration trends for selected waterquality constituents at water-quality station 01395000, Rahway River at Rahway, N.J.

[Number in parenthesis is the number of available data; WY, water years; mg/L, milligrams per liter; $\mathrm{CaCO}_{3}$, calcium carbonate; $\mathrm{C}$, carbon; $\mathrm{Na}$, sodium; $\mathrm{Cl}$, chloride; \%, percent; $\mathrm{P}$, phosphorus; $\mathrm{N}$, nitrogen; $\mu \mathrm{g} / \mathrm{L}$, micrograms per liter; $\mathrm{B}$, boron; $\mathrm{Pb}$, lead; MPN/100 mL, most probable number per 100 milliliters. Regression slopes and trend directions are zero when the slope is not different from zero at the 0.05 significance level; * indicates seasonal dependency (the slope and (or) intercept of growing (April through October) and non-growing (November through March) season data were different at the 0.05 significance level). +, positive trend direction; -, negative trend direction; NA, insufficient data for analysis; $\mathrm{ND}$, undetermined value.]

\begin{tabular}{|c|c|c|c|c|c|c|c|c|c|}
\hline \multirow{3}{*}{$\begin{array}{c}\text { Constituent } \\
\text { Alkalinity, } \mathrm{mg} / \mathrm{L} \text { as } \mathrm{CaCO}_{3}\end{array}$} & \multicolumn{2}{|c|}{ 1989-93 WY } & \multicolumn{7}{|c|}{ 1976-93 WY } \\
\hline & \multicolumn{2}{|c|}{$\begin{array}{c}\text { Median } \\
\text { concentration }\end{array}$} & \multicolumn{2}{|c|}{$\begin{array}{c}\text { Median } \\
\text { concentration }\end{array}$} & \multicolumn{2}{|c|}{$\begin{array}{l}\text { Regression } \\
\text { slope of } \\
\text { concentration to } \\
\text { streamflow }\end{array}$} & \multirow{2}{*}{$\begin{array}{c}\begin{array}{c}\text { Regression } \\
\text { slope of } \\
\text { load to } \\
\text { streamflow }\end{array} \\
0.917\end{array}$} & \multirow{2}{*}{$\begin{array}{c}\text { Low- } \\
\text { flow } \\
\text { trend } \\
\text { direction } \\
\text { NA }\end{array}$} & \multirow{2}{*}{$\begin{array}{c}\text { High- } \\
\text { flow } \\
\text { trend } \\
\text { direction } \\
\text { NA }\end{array}$} \\
\hline & 88 & (27) & 83 & $(75)$ & -0.082 & & & & \\
\hline Total hardness, $\mathrm{mg} / \mathrm{L}$ as $\mathrm{CaCO}_{3}$ & 140 & (27) & 130 & $(86)$ & -.072 & $*$ & .928 & NA & NA \\
\hline Total organic carbon, $\mathrm{mg} / \mathrm{L}$ as $\mathrm{C}$ & 5.1 & (27) & 4.8 & $(85)$ & 0 & $*$ & 1.041 & NA & NA \\
\hline Suspended sediment, $\mathrm{mg} / \mathrm{L}$ & 8 & (11) & 7 & $(21)$ & .630 & & 1.630 & NA & NA \\
\hline Dissolved solids, $\mathrm{mg} / \mathrm{L}$ & 289 & (27) & 248 & $(84)$ & 0 & $*$ & .985 & NA & NA \\
\hline Dissolved sodium, $\mathrm{mg} / \mathrm{L}$ as $\mathrm{Na}$ & 29 & (27) & 24 & $(86)$ & .087 & $*$ & 1.087 & NA & NA \\
\hline Dissolved chloride, $\mathrm{mg} / \mathrm{L}$ as $\mathrm{Cl}$ & 64 & (27) & 45 & $(86)$ & .094 & $*$ & 1.094 & NA & NA \\
\hline Dissolved oxygen, mg/L & 8.7 & (24) & 8.5 & $(81)$ & .075 & $*$ & 1.075 & NA & NA \\
\hline $\begin{array}{l}\text { Fraction of dissolved oxygen at } \\
\text { saturation, } \%\end{array}$ & 95 & $(22)$ & 94 & $(79)$ & .059 & $*$ & ND & NA & NA \\
\hline Total phosphorus, $\mathrm{mg} / \mathrm{L}$ as $\mathrm{P}$ & .09 & (27) & .10 & $(59)$ & .093 & $*$ & 1.093 & NA & NA \\
\hline Total nitrogen, $\mathrm{mg} / \mathrm{L}$ as $\mathrm{N}$ & 1.6 & (27) & 1.6 & $(83)$ & .109 & & 1.109 & NA & NA \\
\hline Total nitrate plus nitrite, $\mathrm{mg} / \mathrm{L}$ as $\mathrm{N}$ & .92 & (27) & .86 & (84) & .206 & $*$ & 1.206 & NA & NA \\
\hline Total nitrite, $\mathrm{mg} / \mathrm{L}$ as $\mathrm{N}$ & .022 & (27) & .020 & $(67)$ & 0 & $*$ & 1.092 & NA & NA \\
\hline $\begin{array}{l}\text { Total ammonia plus organic nitrogen, } \\
\mathrm{mg} / \mathrm{L} \text { as } \mathrm{N}\end{array}$ & .67 & (27) & .70 & $(85)$ & 0 & $*$ & 1.059 & NA & NA \\
\hline Total ammonia, $\mathrm{mg} / \mathrm{L}$ as $\mathrm{N}$ & .06 & (27) & .10 & $(81)$ & 0 & & 1.049 & NA & NA \\
\hline Total boron, $\mu \mathrm{g} / \mathrm{L}$ as $\mathrm{B}$ & 75 & (6) & 70 & $(17)$ & -.187 & & .813 & NA & NA \\
\hline Total lead, $\mu \mathrm{g} / \mathrm{L}$ as $\mathrm{Pb}$ & 5 & (6) & 7 & $(17)$ & .308 & & 1.308 & NA & NA \\
\hline Fecal coliform bacteria, MPN/100 ml & 460 & $(25)$ & 500 & $(83)$ & .417 & $*$ & ND & NA & NA \\
\hline
\end{tabular}

Table 23b. 1993 AMNET impairment status in the vicinity of water-quality station 01395000, Rahway River at Rahway, N.J.

[AMNET, Ambient Biomonitoring Network; WQ, water-quality. Upstream from WQ station is within 5 miles upstream from the WQ station; at WQ-station location is within 0.5 mile upstream or downstream from the WQ station; downstream from WQ station is within 5 miles downstream from the WQ station; ND, undetermined impairment status]

\begin{tabular}{lccc}
\hline & Upstream from WQ station & At WQ-station location & Downstream from WQ station \\
\hline AMNET station & AN0194 & AN0195 & None \\
Impairment status & Moderately impaired & Moderately impaired & ND \\
\hline
\end{tabular}


stations with sufficient data for analysis are discussed. Insufficient data are available for all constituents to determine trends in concentrations during high and low flows at 8 of the 19 waterquality stations. If the data collection schedule for certain sites were changed, more data would be available for analysis. Because of a scarcity of data, a complete comparison between the trends and the slopes of loads to streamflows in the study area is not possible.

In the schematics showing trends in concentrations during low and high flows, symbols are used to indicate a positive (increasing concentrations), negative (decreasing concentrations), or no (insignificant change in concentrations) trend (figs. 9-26). Trends in concentrations during high and low flows indicate trends in contributions from intermittent (storm runoff) and constant (point sources and ground water) sources, respectively. Trends in concentrations during high flows indicate changes in the relative contributions from nonpoint sources because storm runoff contributes to a stream during high flows. Trends in concentrations during low flows indicate changes in the relative contributions from point sources and ground water because storm runoff does not contribute to a stream during low flows.

The steepness of the slope of load to streamflow at a site indicates the relative contributions to the instream load from constant and intermittent sources relative to other sites in the study area. The larger the contribution from storm runoff, the larger the slope will be because the load will increase with increasing streamflow. Likewise, the larger the contribution from constant sources, the smaller the slope will be because the instream load will be constant with increasing streamflow. In the schematics, symbols are used to indicate the range category of the slope at each station. Filled circles represent stations with slopes in the high range, hashed circles represent stations with slopes in the moderate range, and quartered circles represent stations with slopes in the low range. Open circles indicate stations for which slopes that could not be determined because of insufficient data. Only results from stations with slopes in either the high or low range are discussed.

An increase in the magnitude of the slope in the downstream direction along a stream would indicate an increase in the relative contribution to the instream load from the storm runoff and would be evident if the order of circles proceeded from quartered to hashed to solid in the downstream direction. Likewise, a decrease in the magnitude of the slope in the downstream direction along a stream would indicate an increase in the relative contribution to the instream load from point sources and ground water and would be evident if the order of circles proceeded from solid to hashed to quartered in the downstream direction.

\section{Alkalinity}

Alkalinity, an aggregate property of water, is a measure of the capacity of water to neutralize acids and is the sum of all the titratable bases in solution (Eaton and others, 1995). The carbonate contributors to alkalinity, carbonate and bicarbonate, result from the dissociation of dissolved carbon dioxide. The important noncarbonate contributors to alkalinity include hydroxides, silicates, borates, phosphates, and organic ligands, especially acetate and propionate. In many surface-water bodies, alkalinity is primarily a function of carbonate, bicarbonate, and hydroxide and represents their combined concentrations. Alkalinity measurements are important in the evaluation and control of potable water and wastewater processes, including chemical 
coagulation, water softening, corrosion control, and buffer capacity evaluation. In surface water that supports extensive algal blooms, consumption of carbon dioxide by algae for photosynthesis causes an increase in $\mathrm{pH}$ due to a shift in the forms of alkalinity, although there is no change in the total alkalinity (Sawyer and McCarty, 1978). Alkalinity in excess of alkaline-earth element concentrations could make water unsuitable for irrigation. Carbonate concentrations can be estimated from alkalinity measurements and used to compute the ion balance when checking water analyses.

\section{$\underline{\text { Relation of trends in concentration to flow conditions }}$}

Insufficient data are available to determine trends in alkalinity during low and high flows at all stations in the study area (figs. 9a and b).

\section{$\underline{\text { Relation of load to streamflow }}$}

The range categories of regression slopes of alkalinity load to streamflow are depicted in figure 9c. The slopes range from 0.617 at station 3818 on the Whippany River (table 12a) to 0.917 at station 3950 on the Rahway River (table 23a). Slopes are in the high range at stations on the Hackensack (3770), Pequannock (3825), and Saddle (3915) Rivers, and the downstream station on the Rahway River (3950). At these sites, the contributions to instream alkalinity loads from storm runoff are larger and less influenced by point sources and ground water than at other sites in the study area. Slopes are in the low range at all stations on the Rockaway (3805 and 3812) and Whippany (3815 and 3818) Rivers, the downstream station on the upper Passaic River (3820), and the one station on the Elizabeth River (39345). At these sites, the contributions to instream alkalinity loads from point sources and ground water are larger and less influenced by storm runoff than at other sites in the study area.

\section{Hardness}

Hardness, an aggregate property of water, is an important consideration in determining the suitability of water for domestic and industrial uses. Hardness, historically described as a measure of the capacity of water to precipitate soap, is typically caused by divalent metallic cations, namely calcium, magnesium, strontium, ferrous iron, and manganous ions (Sawyer and McCarty, 1978). Other polyvalent cations also can precipitate soap, but they are often in complex forms, frequently with organic constituents, and their role in water hardness may be minimal and difficult to define (Eaton and others, 1995). Cation concentrations can be estimated from hardness measurements and used to compute the ion balance when checking water analyses.

Calcium and magnesium, the major contributors to hardness, are often the major cations in surface water. Calcium is the most abundant of the alkaline-earth elements and is a major constituent of many common rock minerals; it is an essential element for plant and animal life. Calcium geochemical behavior is governed by the availability of soluble calcium-containing minerals, solution- and gas-phase equilibria that involve carbon dioxide species, and the availability of sulfur in the form of sulfate (Hem, 1985). Calcium also participates in cationexchange equilibria at aluminosilicate and other mineral surfaces. Calcium salts used for deicing highways can be carried to surface water by storm runoff and melting snow. Magnesium is an 
(A)

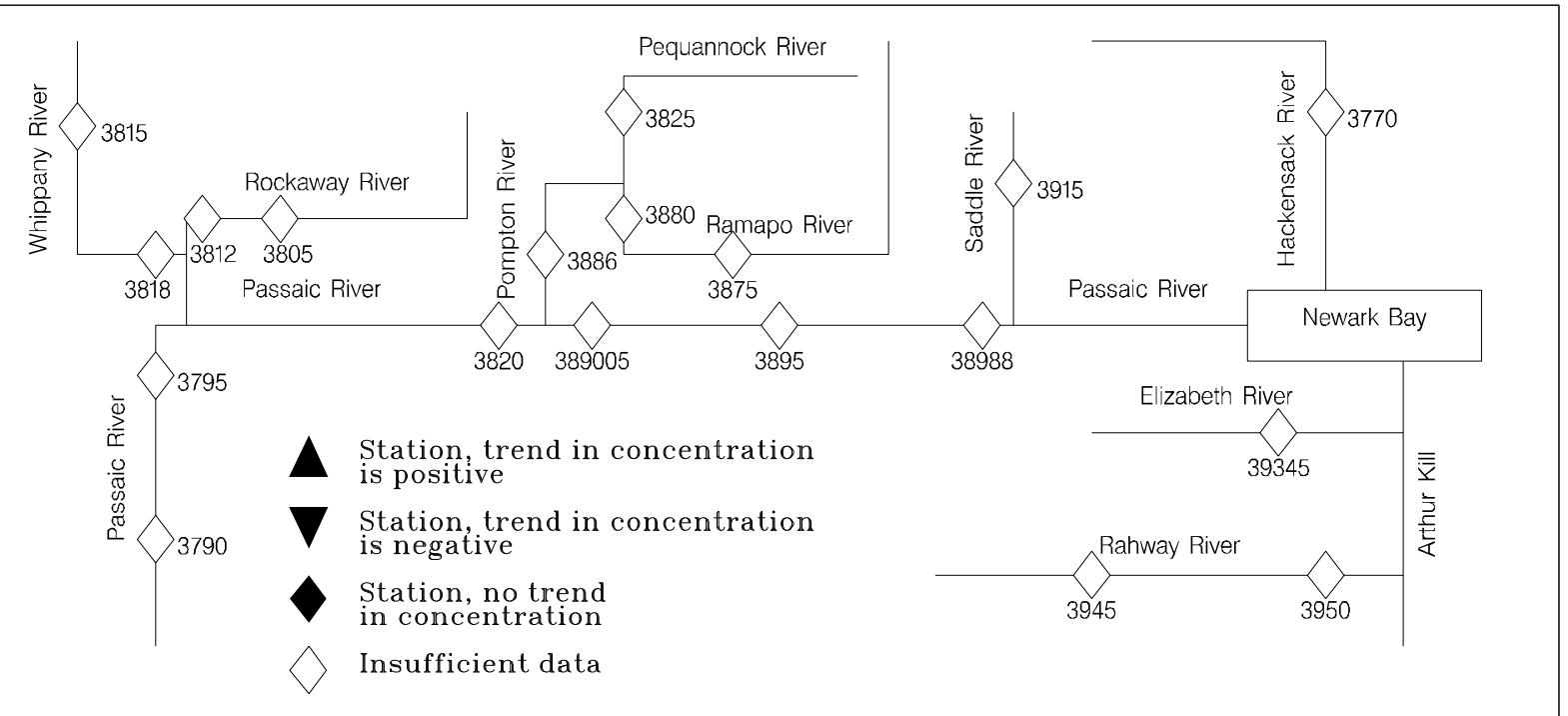

(B)

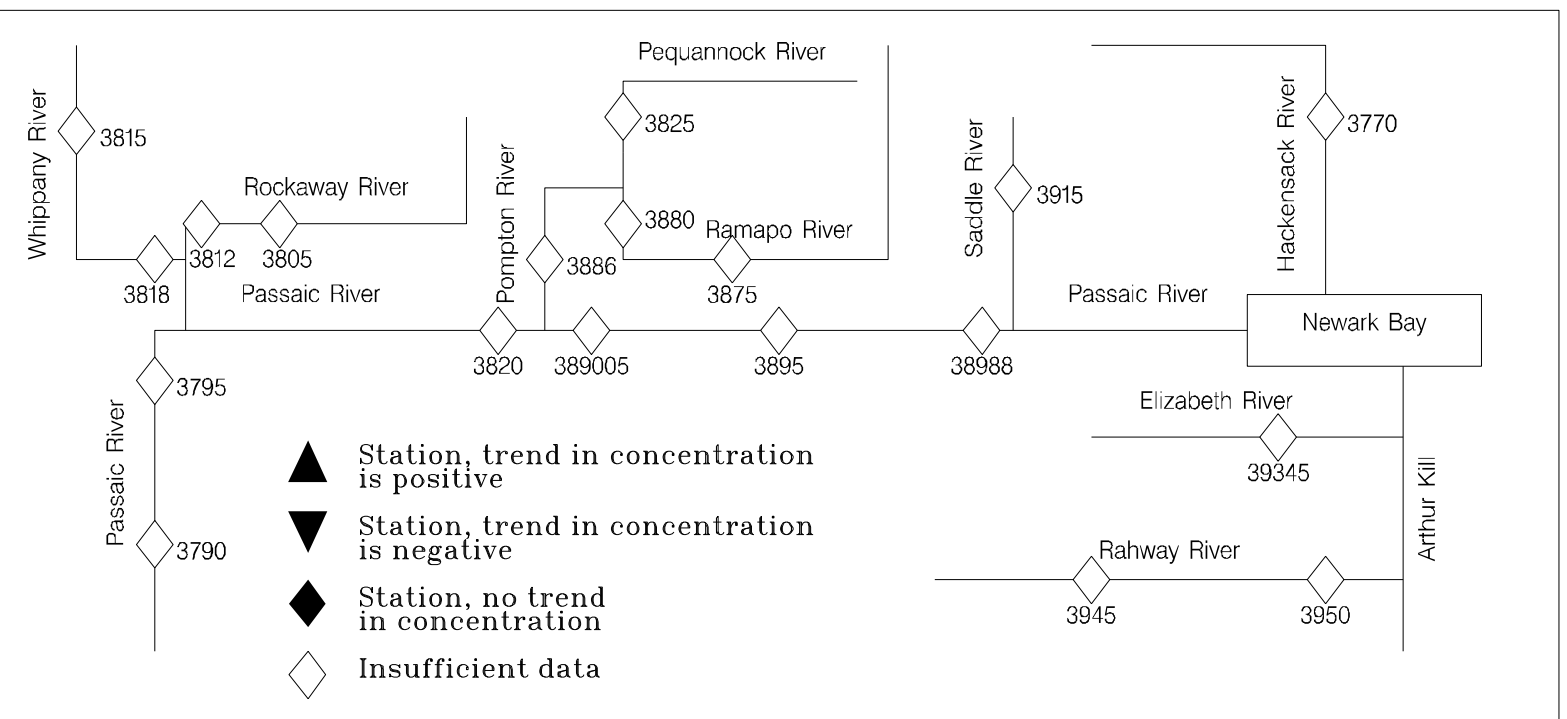

(C)

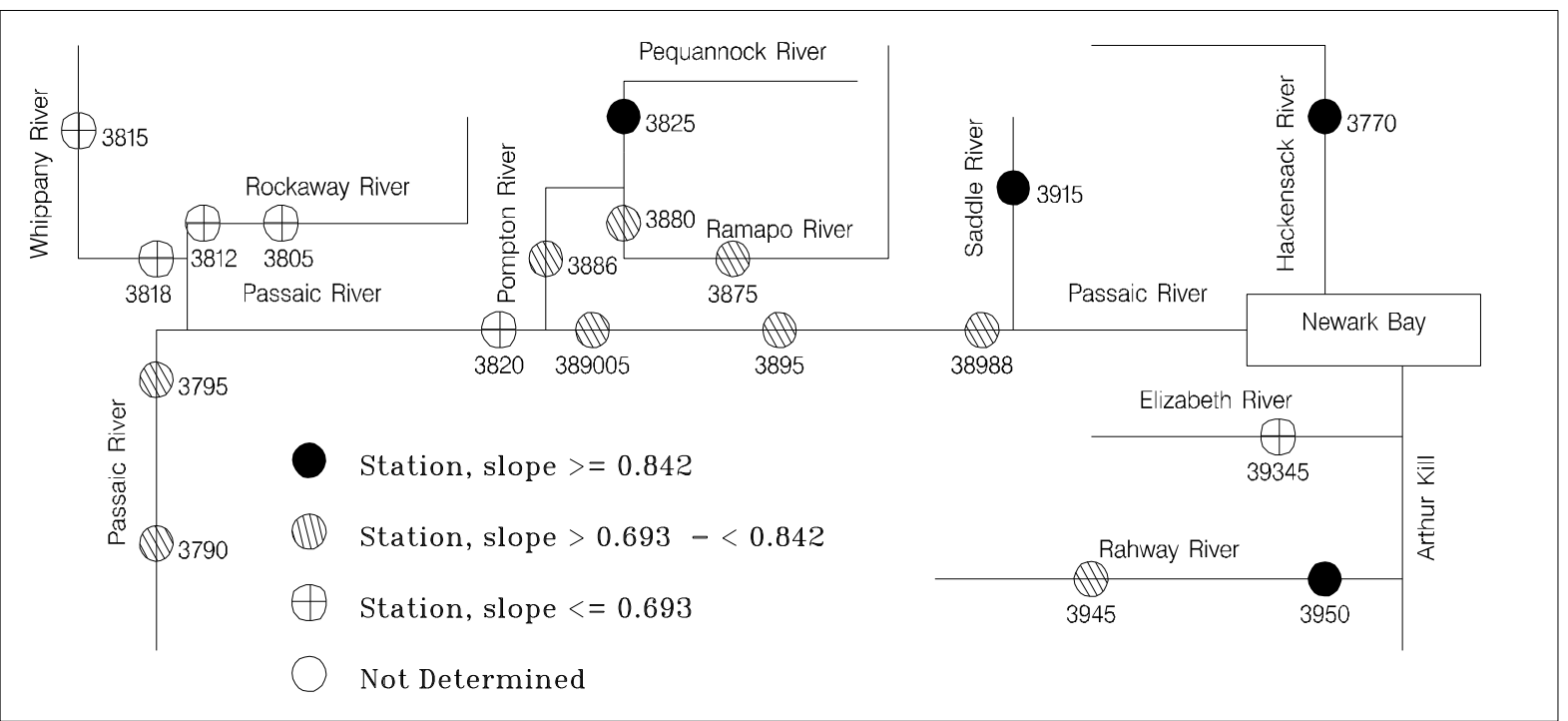

Figure 9. Trends in alkalinity concentrations during (A) high- and (B) low-flow conditions, and $(C)$ relative slope of alkalinity load to streamflow at surface-water-quality stations in the Hackensack, Passaic, Elizabeth, and Rahway River Basins, N.J., water years 1976-93. 
alkaline-earth element and is essential in plant and animal nutrition. The water chemistry of calcium and magnesium is similar; however, the geochemical behavior is different. The cationexchange behavior of magnesium is similar to that of calcium.

\section{$\underline{\text { Relation of trends in concentration to flow conditions }}$}

The trends in hardness concentrations during high flows are positive at the most upstream station on the upper Passaic River (3790) and the one station on the Saddle River (3915), indicating an increase in the contributions from storm runoff at these stations over time (fig. 10a). Hardness concentrations during high flows show no trends at the downstream stations on the upper Passaic (3795 and 3820) and Rockaway (3812) Rivers, both stations on the Whippany River (3815 and 3818), and station 3895 on the lower Passaic River. The trends in hardness concentrations during low flows are positive at the downstream station on the upper Passaic River (3820), indicating an increase in the contribution from point sources and ground water over time at this site (fig. 10b). Hardness concentrations during low flows show no trends at the upstream station on the Ramapo River (3875), station 3895 on the upper Passaic River, and the one station on the Saddle River (3915).

\section{Relation of load to streamflow}

The range categories of regression slopes of hardness load to streamflow are depicted in fig. 10c. The slopes range from 0.561 at station 39345 on the Elizabeth River (table 21a) to 0.928 at station 3950 on the Rahway River (table 23a). Slopes are in the high range at the one station each on the Hackensack (3770) and Pequannock (3825) Rivers, and the downstream station on the Rahway River (3950). At these sites, the contributions to instream hardness load from storm runoff are larger and less influenced by point sources and ground water than at other sites in the study area. Slopes are in the low range at the downstream station on the Whippany River (3818) and the one station on the Elizabeth River (39345). At these sites, the contributions to instream hardness loads from point sources and ground water are larger and less influenced by storm runoff than at other sites.

\section{Total Organic Carbon}

The concentration of total organic carbon (TOC), an aggregate property of water, is a measure of the organic compounds in various oxidation states in surface water (Eaton and others, 1995). TOC concentrations in most surface water are small compared to dissolved inorganic solute concentrations. Although the presence of organic compounds in surface water can cause an oxygen demand as organisms decompose the compounds, a measure of TOC does not represent a measure of other organically bound elements, such as nitrogen and hydrogen, or inorganics that can contribute to the oxygen demand as measured by the biochemical or chemical oxygen demands.

The methods used to measure TOC analyze fractions of total carbon. These fractions are defined as inorganic carbon, the carbonate, bicarbonate, and dissolved carbon dioxide removed from solution by gas stripping under specified conditions; TOC, all carbon atoms covalently bonded in organic molecules; dissolved organic carbon (DOC), the fraction of TOC that passes 
(A)

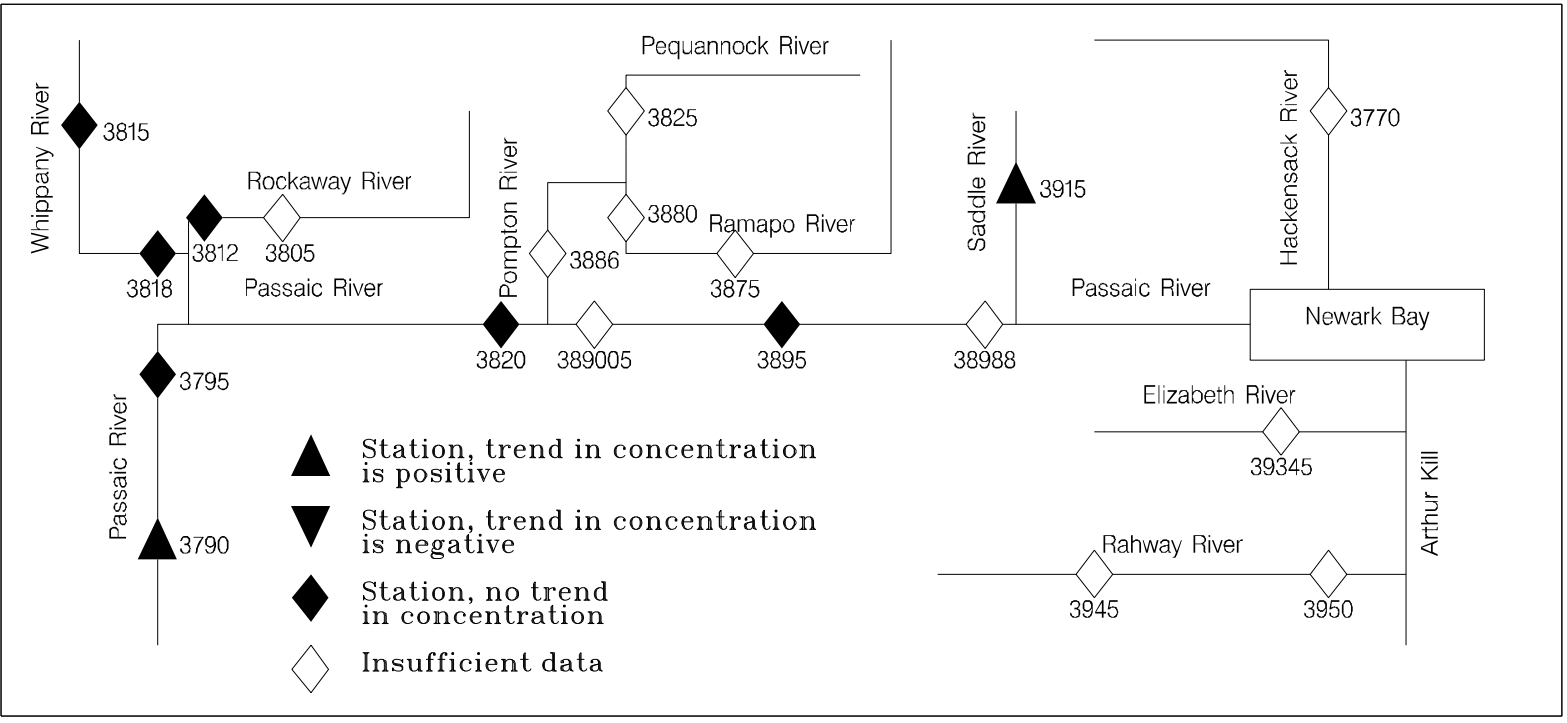

(B)

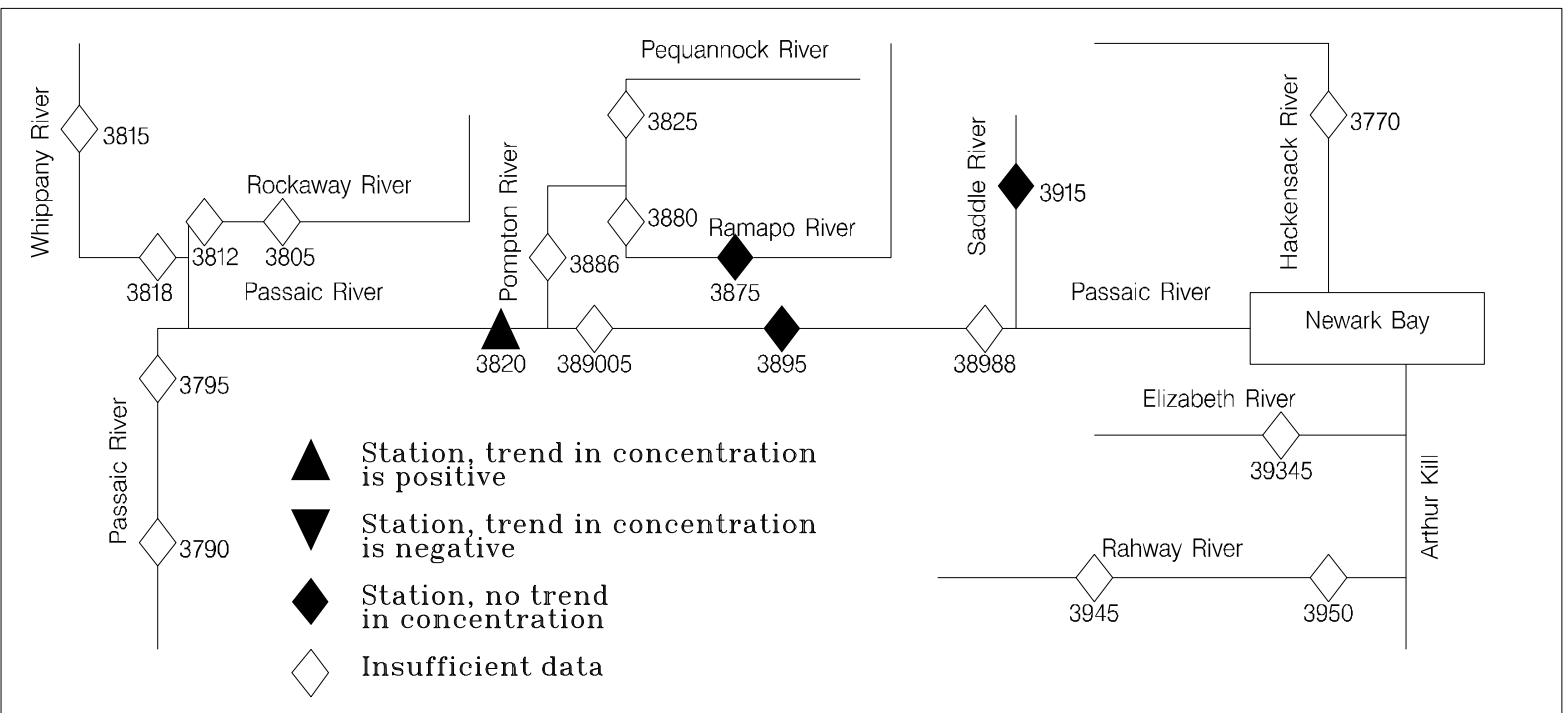

(C)

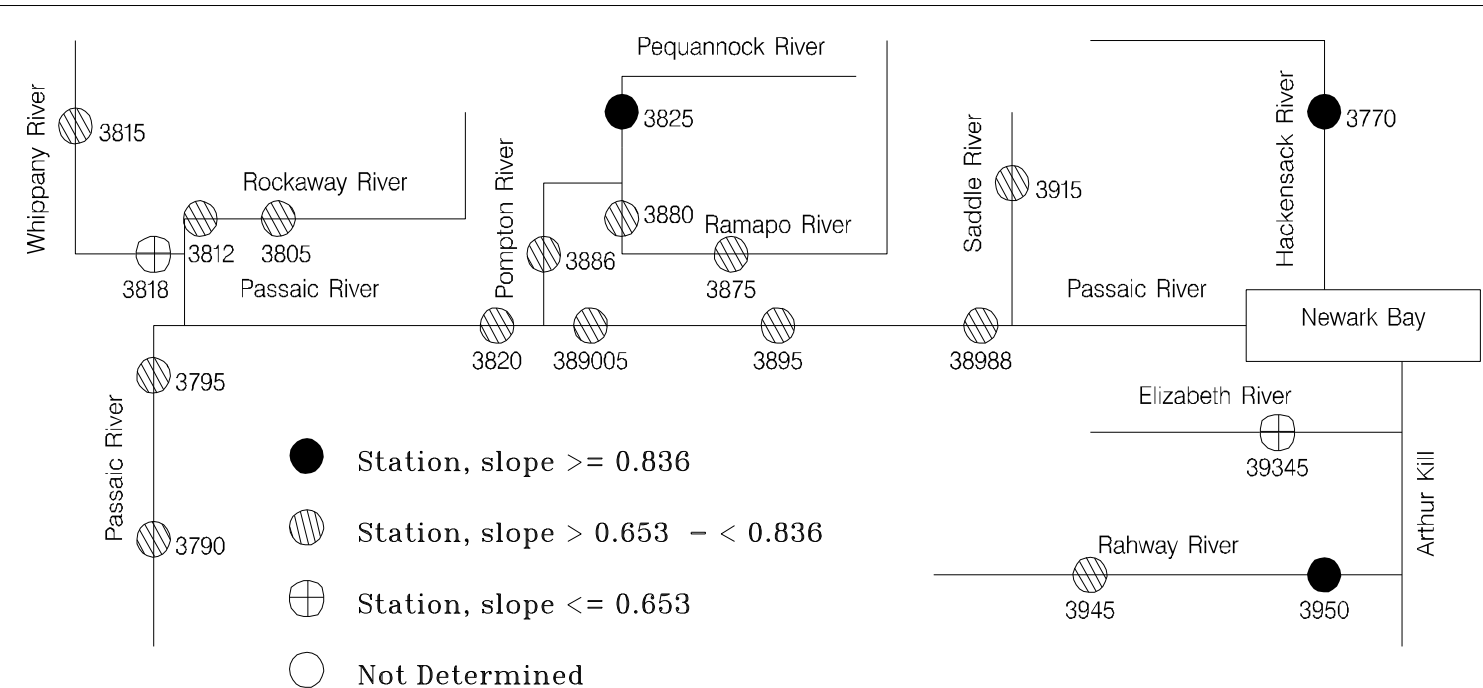

Figure 10. Trends in hardness concentrations during $(A)$ high- and $(B)$ low-flow conditions, and $(C)$ relative slope of hardness load to streamflow at surface-waterquality stations in the Hackensack, Passaic, Elizabeth, and Rahway River Basins, N.J., water years 1976-93. 
through a $0.45 \mu \mathrm{m}$-pore-diameter filter; particulate organic carbon (POC), the fraction of TOC that is retained by a $0.45 \mu \mathrm{m}$-pore-diameter filter; volatile organic carbon (VOC), the fraction of TOC removed from an aqueous solution by gas stripping under specified conditions; and nonpurgeable organic carbon, the fraction of TOC not removed by gas stripping. In most surface water, the VOC contribution to TOC is negligible. When not measured directly, TOC concentration is calculated as the sum of the DOC and POC concentrations.

\section{$\underline{\text { Relation of trends in concentration to flow conditions }}$}

The trend in TOC concentrations during high flow is negative at the downstream station on the Rockaway River (3812), indicating a decrease in the contribution from storm runoff at this station (fig. 11a). TOC concentrations during high flows show no trend at any station on the upper Passaic (3790, 3795, and 3820) or Whippany (3815 and 3818) Rivers. TOC concentrations during low flows show no trend at the downstream station on the upper Passaic River (3820), the upstream station on the Ramapo River (3875), and the one station on the Saddle River (3915) (fig. 11b). Hay and Campbell (1990) reported a downward trend in TOC concentrations in the Rockaway River during an 11-year study period (water years 1976-86).

\section{Relation of load to streamflow}

The range categories of regression slopes of TOC load to streamflow are depicted in figure 11c. The slopes range from 0.816 at station 3880 on the Ramapo River (table 15a) to 1.219 at station 39345 on the Elizabeth River (table 21a). At station 39345 on the Elizabeth River, the slope is in the high range where the contributions to instream TOC load from storm runoff are larger and less influenced by point sources and ground water than at other sites in the study area. Slopes are in the low range at both stations on the Ramapo River (3875 and 3880) and the one station on the Pompton River (3886). At these sites, however, the contributions to instream TOC loads from point sources and ground water probably are relatively insignificant because the loadto-streamflow slopes are large (greater than 0.8). Storm runoff most likely is a major contributor of TOC in the study area because the load-to-streamflow slopes at all stations are large.

\section{Suspended Sediment}

Suspended sediment, an aggregate property of water, is that part of total solids that is retained by a filter under specified conditions; its concentration is determined by the weight of the dry residue remaining after evaporation of the volatile part of a sample aliquot by heating to $105^{\circ} \mathrm{C}$ (Eaton and others, 1995). Large concentrations of suspended sediments in surface water could inhibit light penetration to bottom-dwelling macrophytes and create esthetically unsatisfactory conditions for such purposes as swimming. Some metals, nutrients, and organic compounds can associate with the surface of suspended sediment and be transported with the suspended sediment in surface water. Suspended sediment concentration is the velocity-weighted concentration of suspended sediment in the sampled zone (from the water surface to a constant approximately 0.3 feet above the bed) (Bauersfeld and others, 1994). 
(A)

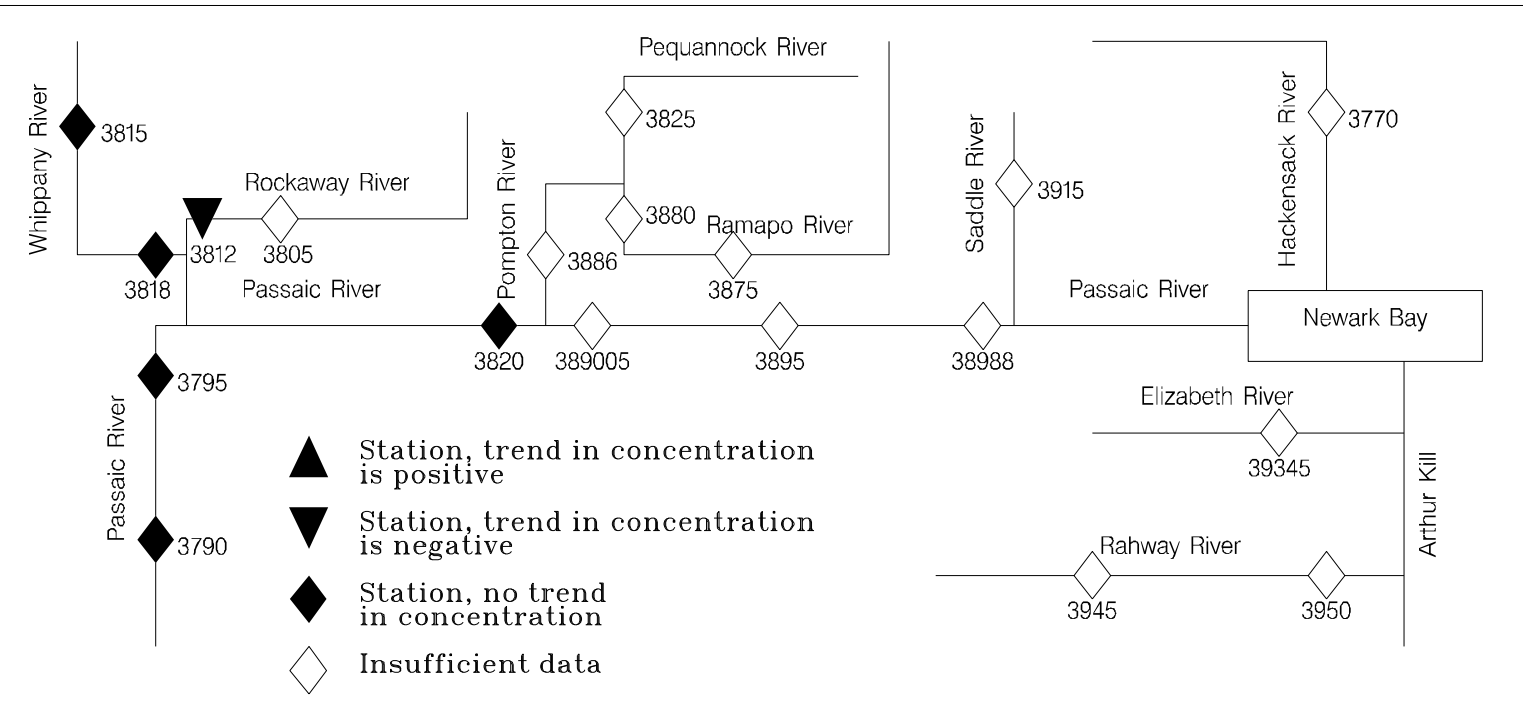

(B)

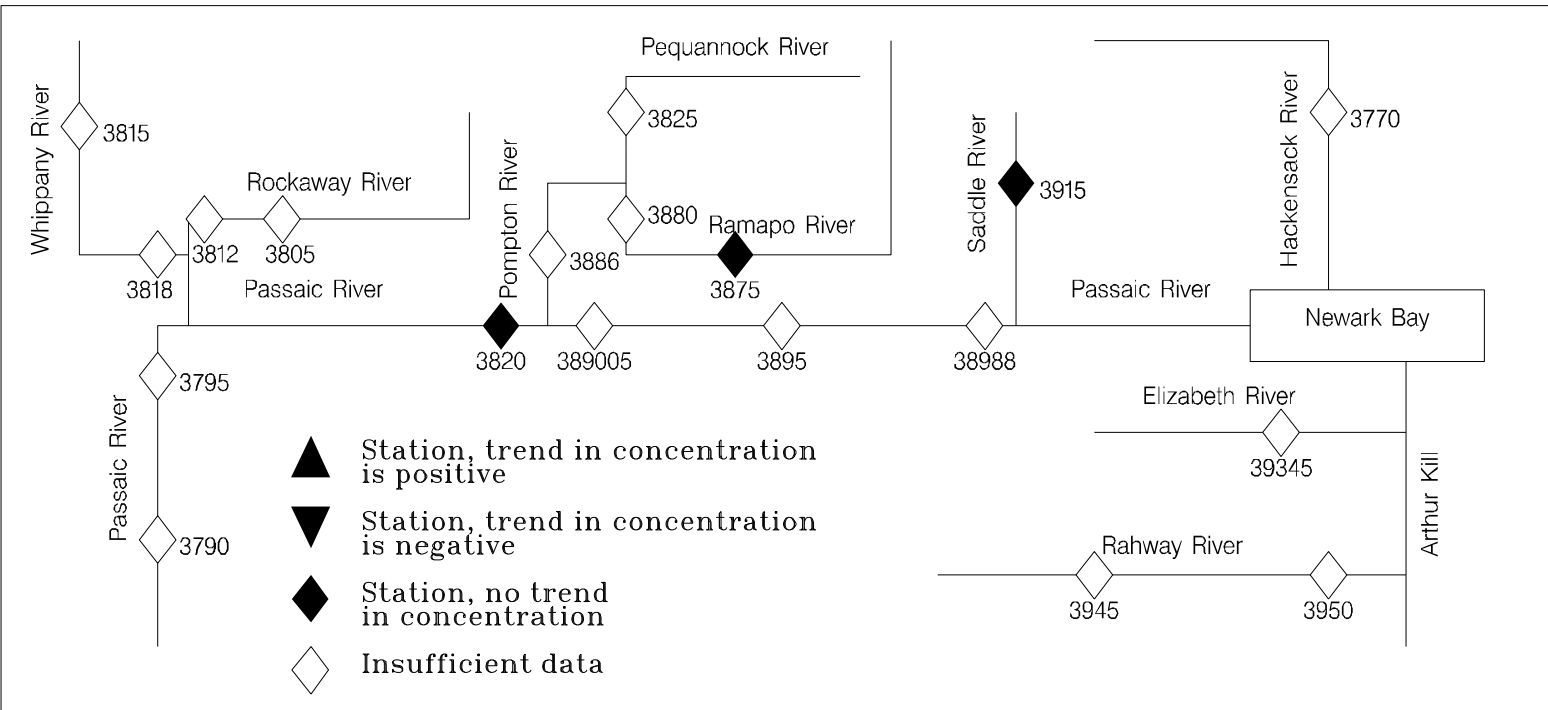

(C)

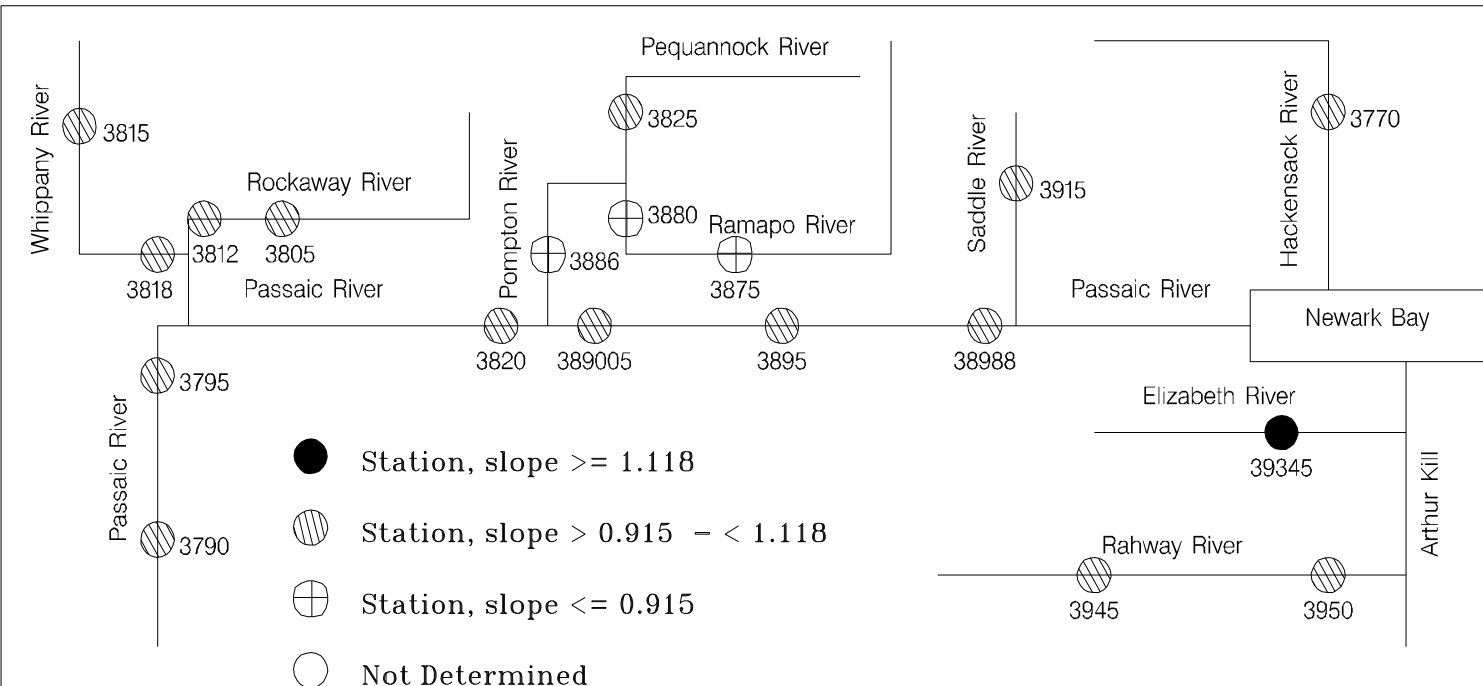

Figure 11. Trends in total organic carbon concentrations during (A) high- and (B) lowflow conditions, and $(C)$ relative slope of total organic carbon load to streamflow at surface-water-quality stations in the Hackensack, Passaic, Elizabeth, and Rahway River Basins, N.J., water years 1976-93. 


\section{$\underline{\text { Relation of trends in concentration to flow conditions }}$}

The trend in suspended sediment concentrations during high flows is negative at station 3895 on the lower Passaic River, indicating a decrease in the contribution from storm runoff at this station (fig. 12a). Insufficient data are available to determine trends in suspended sediment concentrations during low flows at all stations in the study area (figs. 12b).

\section{$\underline{\text { Relation of load to streamflow }}$}

The range categories of regression slopes of suspended sediment load to streamflow are depicted in figure 12c. The slopes range from 0.849 at station 3790 (table 6a) on the upper Passaic River to 1.915 at station 39345 on the Elizabeth River (table 21a). The load-tostreamflow slopes are larger for suspended sediment than for any other constituent at all stations. During high flows, the stream velocity can become sufficient to scour the streambed, thereby, making the streambed a source of measured instream load. The influence of streamflow velocity on the magnitude of the load-to-streamflow slope ideally is considered when evaluating the influence of point sources and storm runoff.

Slopes are in the high range at the upstream station on the Whippany River (3815) and the one station on the Elizabeth River (39345) where the contributions to instream suspended sediment loads from storm runoff are larger and less influenced by point sources and ground water than at other sites. Slopes are in the low range at the upstream (3790) and downstream (3820) stations on the upper Passaic River and the one station on the Saddle River (3915). At these sites, however, the contributions to suspended sediment loads from point sources and ground water are probably relatively insignificant because the load-to-streamflow slopes are large (greater than 0.8). Storm runoff most likely is the dominant contributor of suspended sediment in the study area because the load-to-streamflow slopes at all stations are large.

\section{Dissolved Solids}

Dissolved solids, an aggregate property of water, is that part of total solids that passes through a filter of $0.45-\mu \mathrm{m}$ (or smaller) nominal pore size under specified conditions; its concentration is determined by the weight of the dry residue remaining after evaporation of the volatile part of a sample aliquot by heating to $180^{\circ} \mathrm{C}$, the residue-upon-evaporation method (Eaton and others, 1995). All carbonates and bicarbonates will break down when heated, but organic matter will be only partially volatilized and not completely removed. Water with large concentrations of dissolved solids generally has an inferior palatability and may induce diarrhea. Salts used for deicing highways can be carried to surface water by storm runoff and melting snow and can contribute to the dissolved solids load. The dissolved solids concentration can be compared to the computed ion balance when checking a water analysis. 
(A)

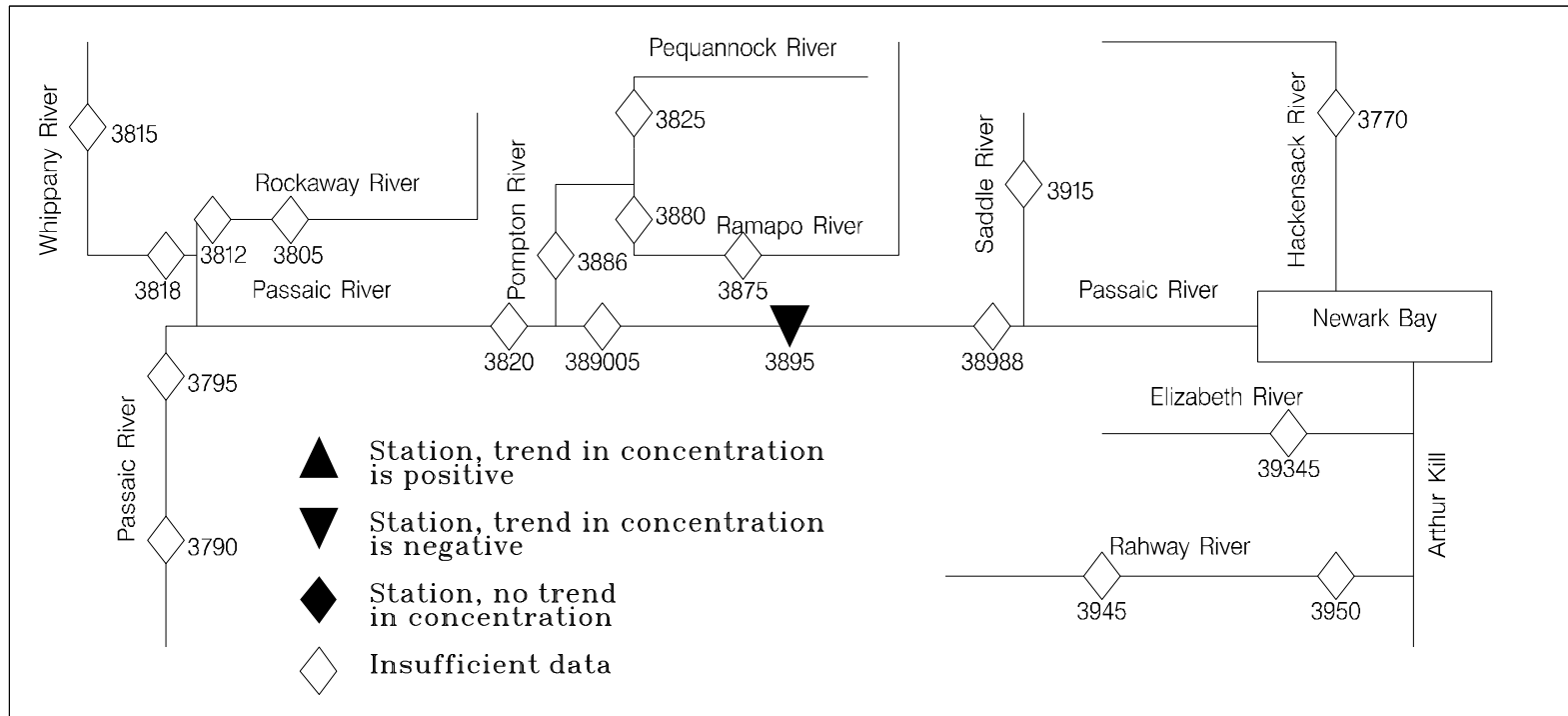

(B)

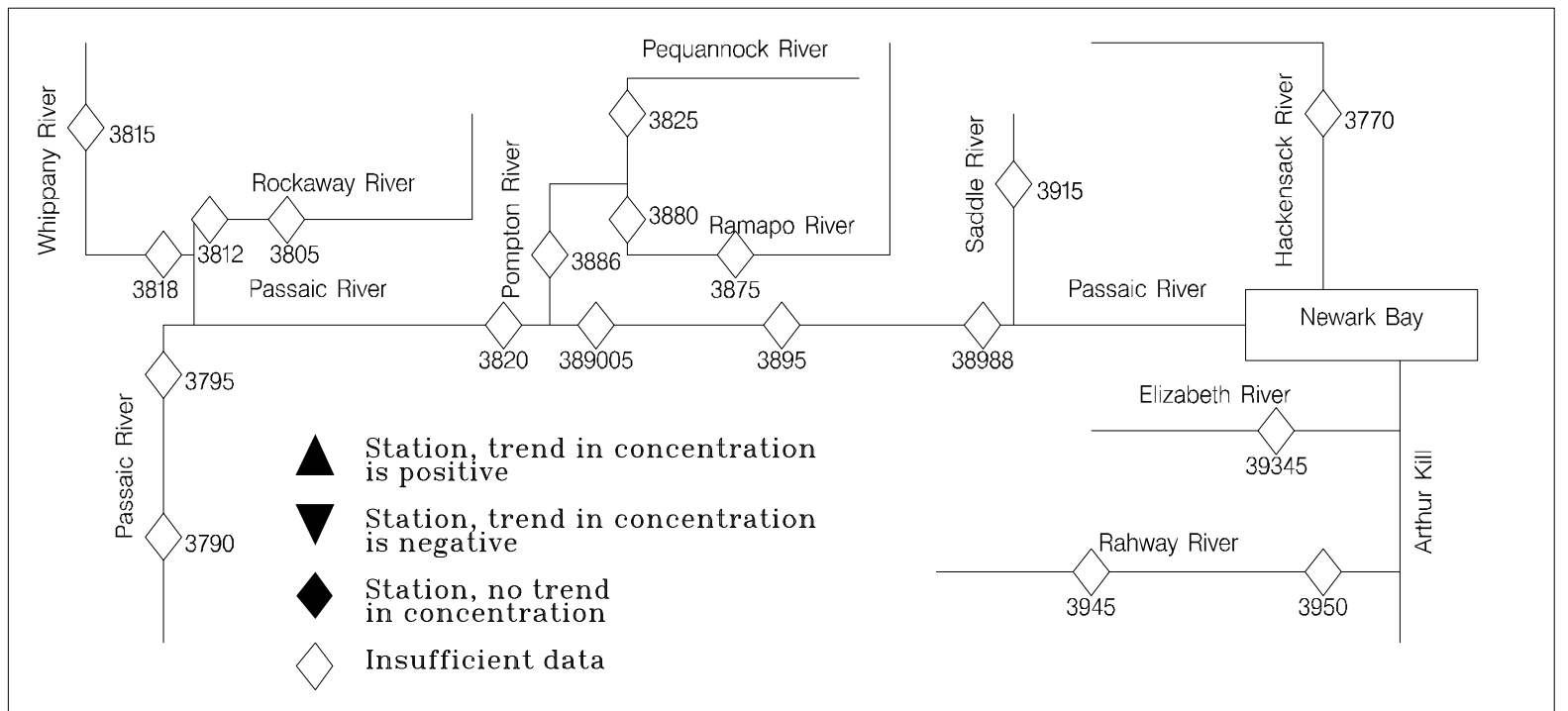

(C)

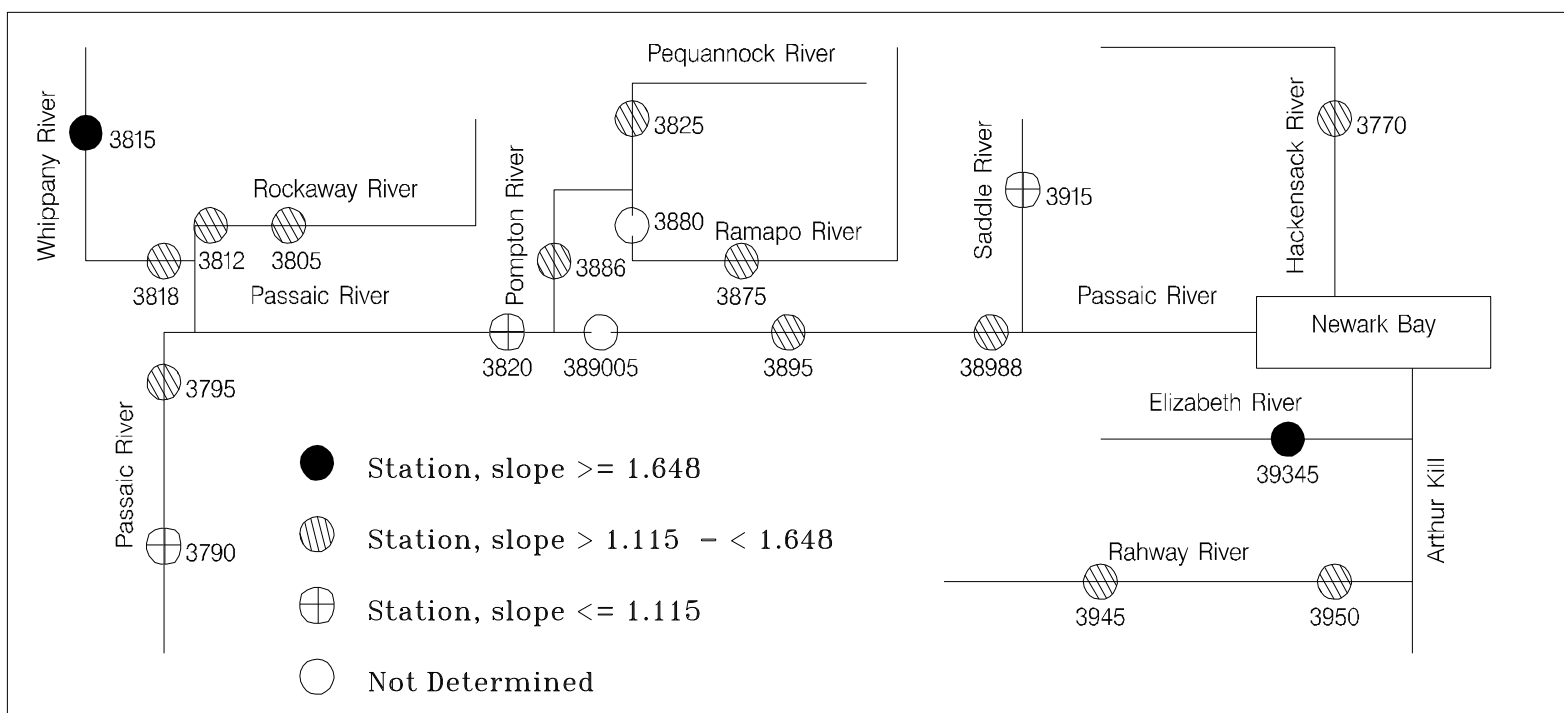

Figure 12. Trends in suspended sediment concentrations during (A) high- and (B) lowflow conditions, and $(C)$ relative slope of suspended sediment load to streamflow at surface-water-quality stations in the Hackensack, Passaic, Elizabeth, and Rahway River Basins, N.J., water years 1976-93. 


\section{$\underline{\text { Relation of trends in concentration to flow conditions }}$}

The trend in dissolved solids concentrations during high flows is positive at the downstream station on the Rockaway River (3812), indicating an increase in the contribution from storm runoff over time at this station (fig. 13a). Dissolved solids concentrations during high flows show no trends at any of the stations on the upper Passaic (3790, 3795, and 3820) and Whippany (3815 and 3818) Rivers, at station 3895 on the lower Passaic River, and at the one station on the Saddle River (3915). During low flows, concentrations of dissolved solids show no trends at the downstream station on the upper Passaic River (3820), the upstream station (3875) on the Ramapo River, station 3895 on the lower Passaic River, and the one station on the Saddle River (3915) (fig. 13b).

\section{$\underline{\text { Relation of load to streamflow }}$}

The range categories of regression slopes of dissolved solids load to streamflow are depicted in figure 13c. The slopes range from 0.619 at station 39345 on the Elizabeth River (table 21a) to 0.985 at station 3950 on the Rahway River (table 23a). Slopes are in the high range at the one station on the Hackensack River (3770) and at both stations on the Rahway River (3945 and 3950). At these sites, the contributions to instream dissolved solids loads from storm runoff are larger and less influenced by point sources and ground water than at other sites in the study area. Slopes are in the low range at the downstream stations on the upper Passaic River (3795 and 3820), the downstream station on the Whippany River (3818), the upstream station on the lower Passaic River (389005), and the one station on the Elizabeth River (3945). At these sites, the contributions to instream dissolved solids loads from point sources and ground water are larger and less influenced by storm runoff than at other sites in the study area.

\section{Dissolved Sodium}

Sodium is present in most surface water. The ratio of sodium to total cations is important in agriculture and human pathology. Sodium tends to remain in solution, when dissolved from rocks by weathering, and not form precipitates that can maintain low sodium concentrations. Sodium is retained by adsorption on mineral surfaces, especially by minerals with high cationexchange capacities, such as clays. Cation exchange processes in freshwater systems tend to extract divalent ions from solution and replace then with monovalent ions, especially sodium (Hem, 1985). Sodium salts used for deicing highways can be carried to surface water by storm runoff and melting snow. The reuse of water for irrigation commonly leaves a residual that is much higher in sodium concentration than was the original water.

\section{$\underline{\text { Relation of trends in concentration to flow conditions }}$}

The trends in sodium concentrations during high flows are positive at the downstream station on the Rockaway River (3812) and the one station on the Saddle River (3915), indicating an increase in the contributions from storm runoff over time at these stations (fig. 14a). Sodium concentrations during high flows show no trends at any of the stations on the upper Passaic (3790, 3795, and 3820) and Whippany (3815 and 3818) Rivers, and station 3895 on the lower Passaic River. Sodium concentrations during low flows show no trends at the downstream station on the 
(A)

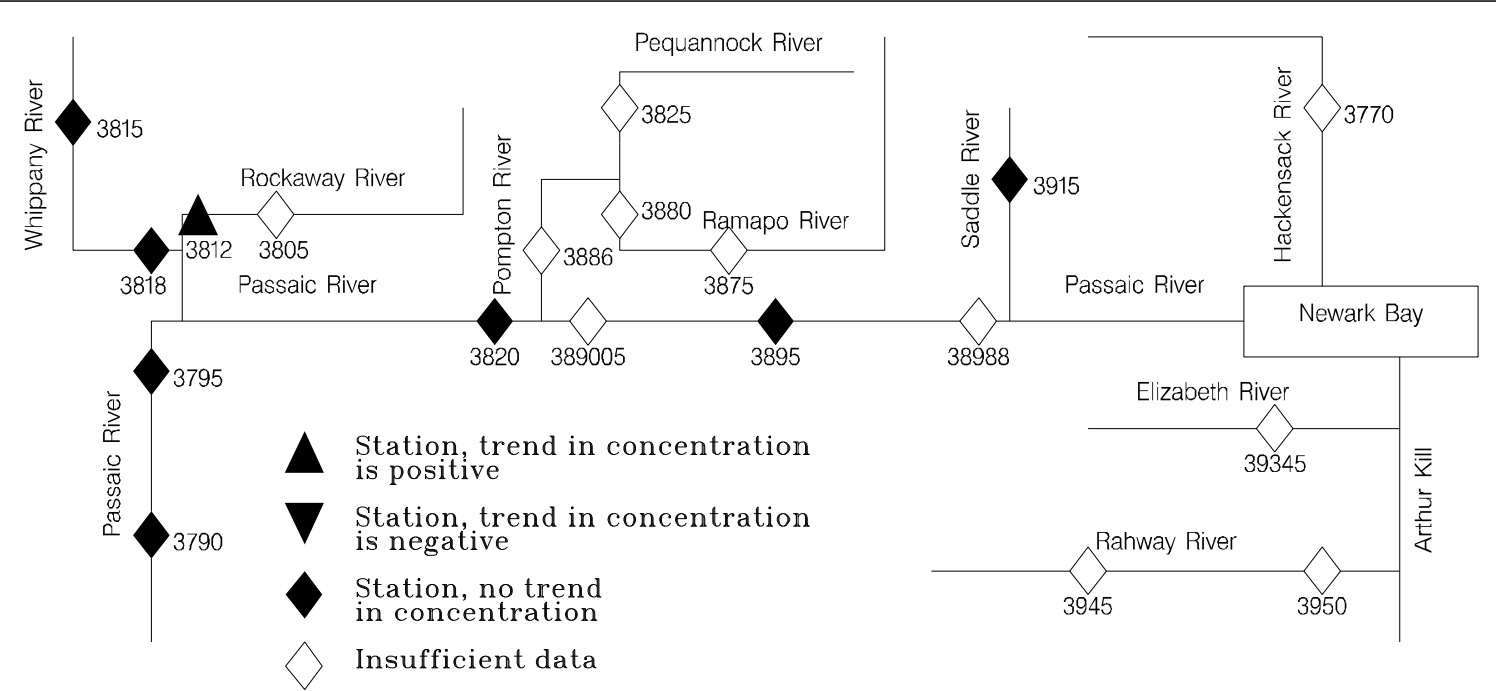

(B)

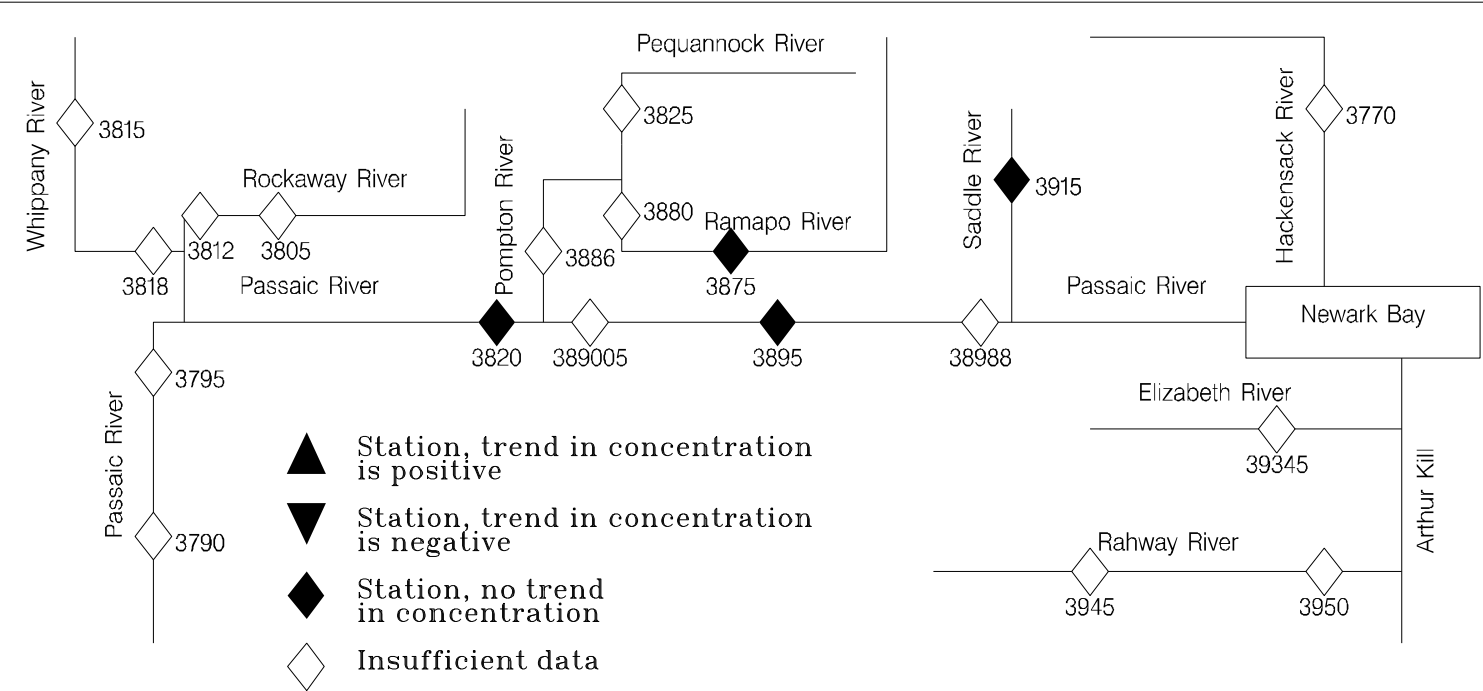

(C)

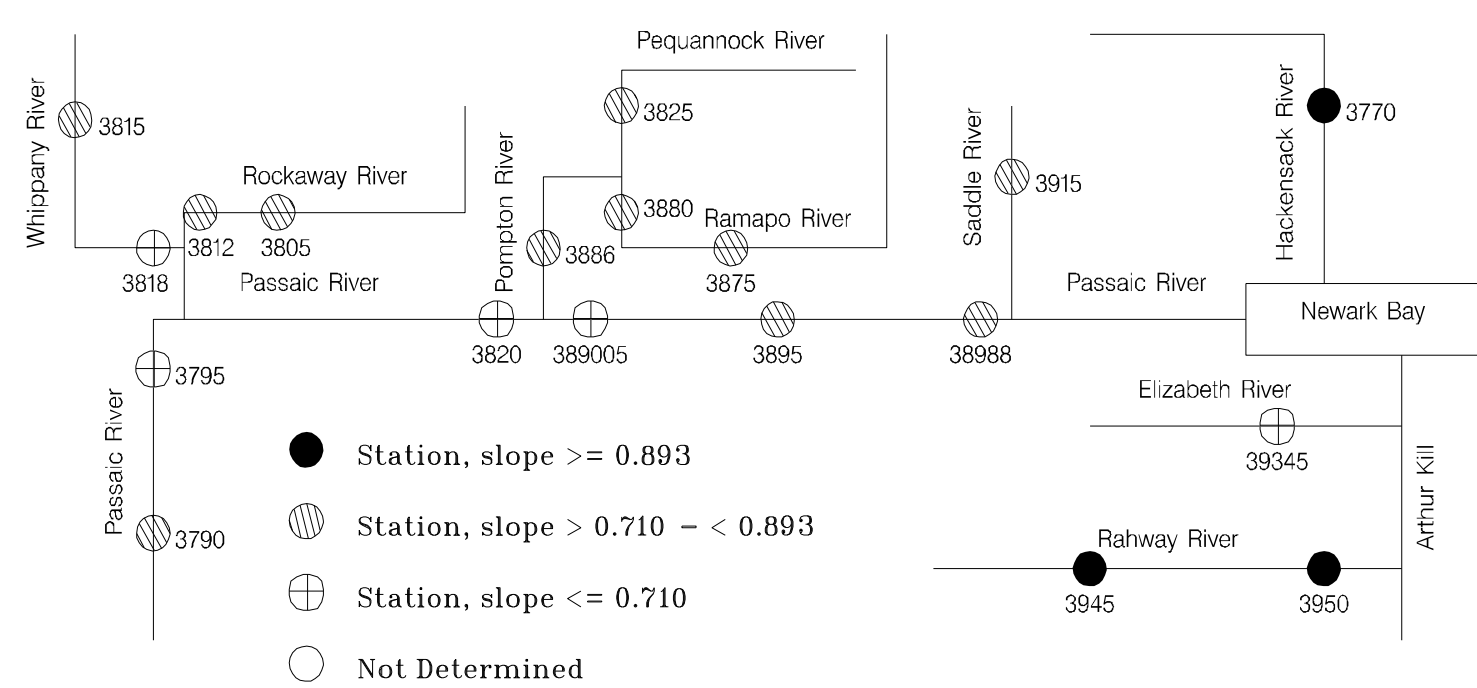

Figure 13. Trends in dissolved solids concentrations during $(A)$ high- and $(B)$ low-flow conditions, and $(\mathrm{C})$ relative slope of dissolved solids load to streamflow at surface-waterquality stations in the Hackensack, Passaic, Elizabeth, and Rahway River Basins, N.J., water years 1976-93. 
(A)

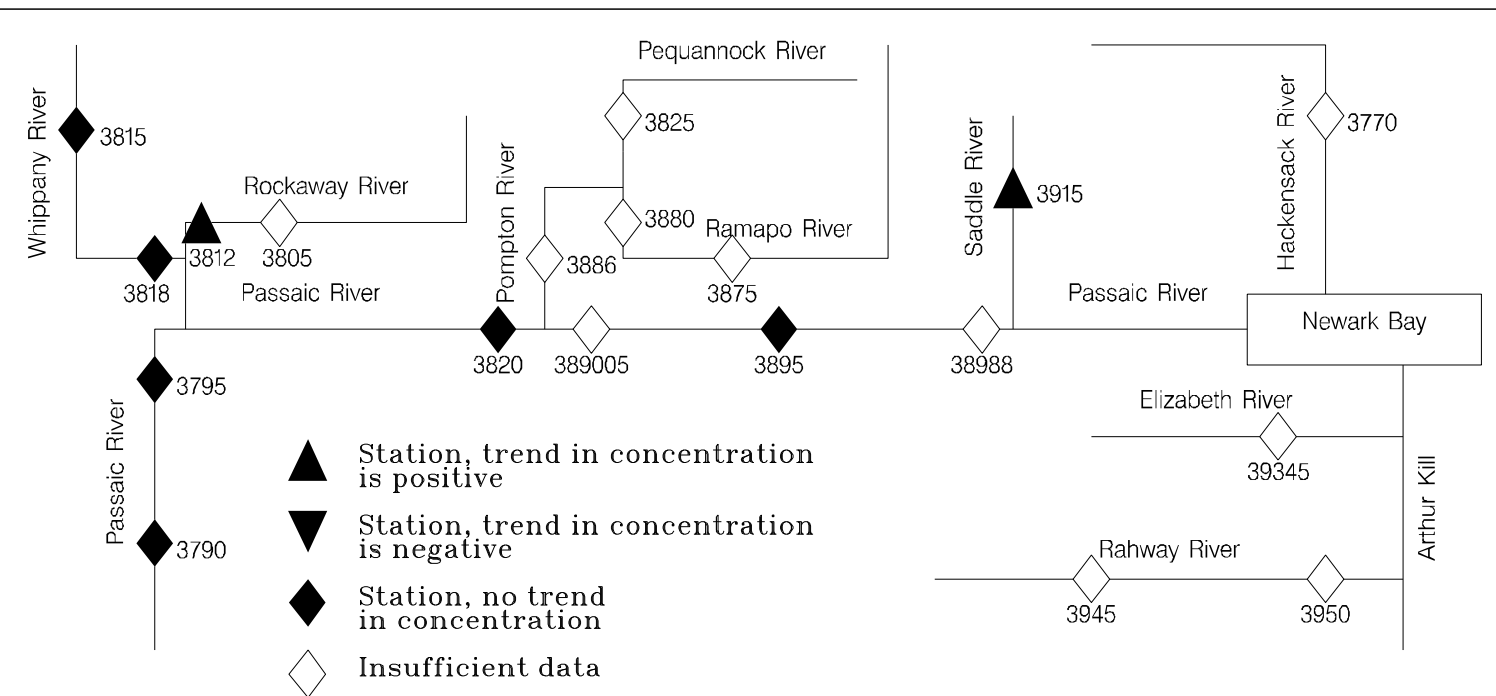

(B)

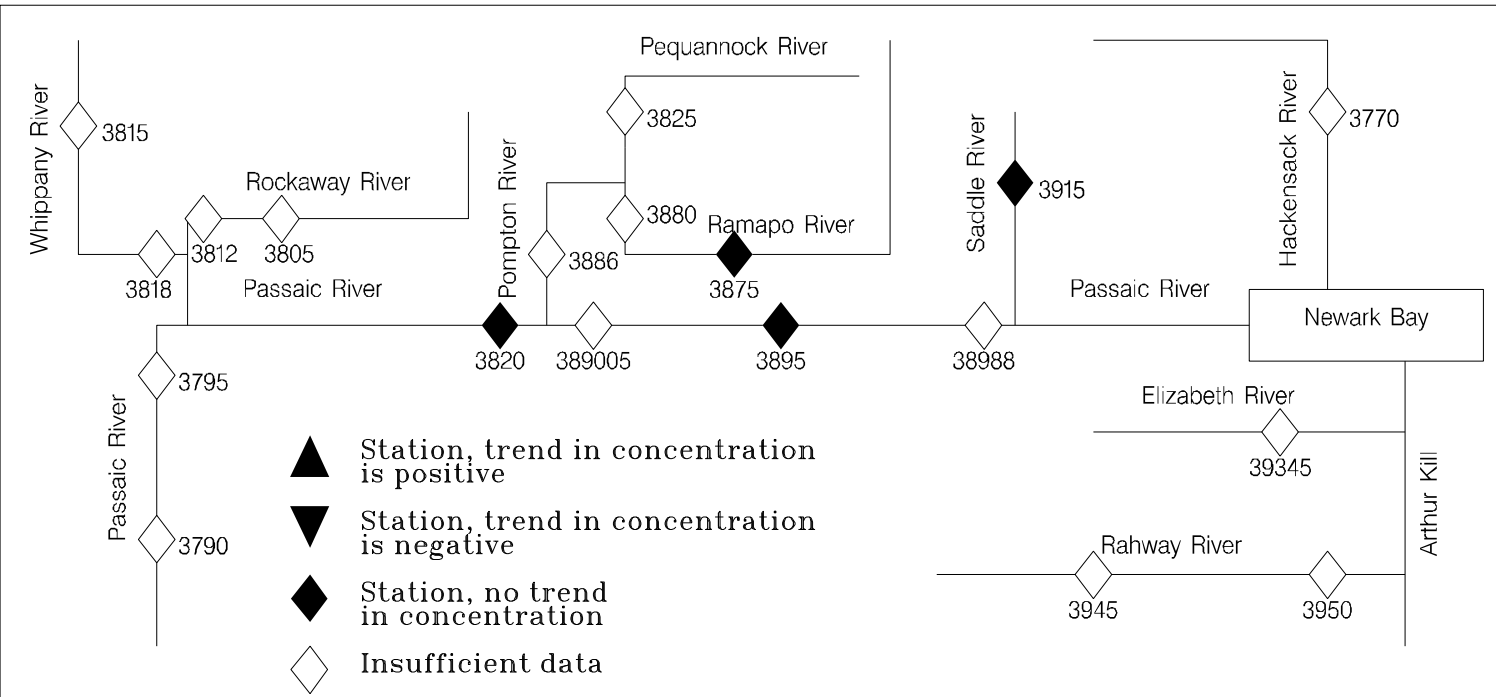

(C)

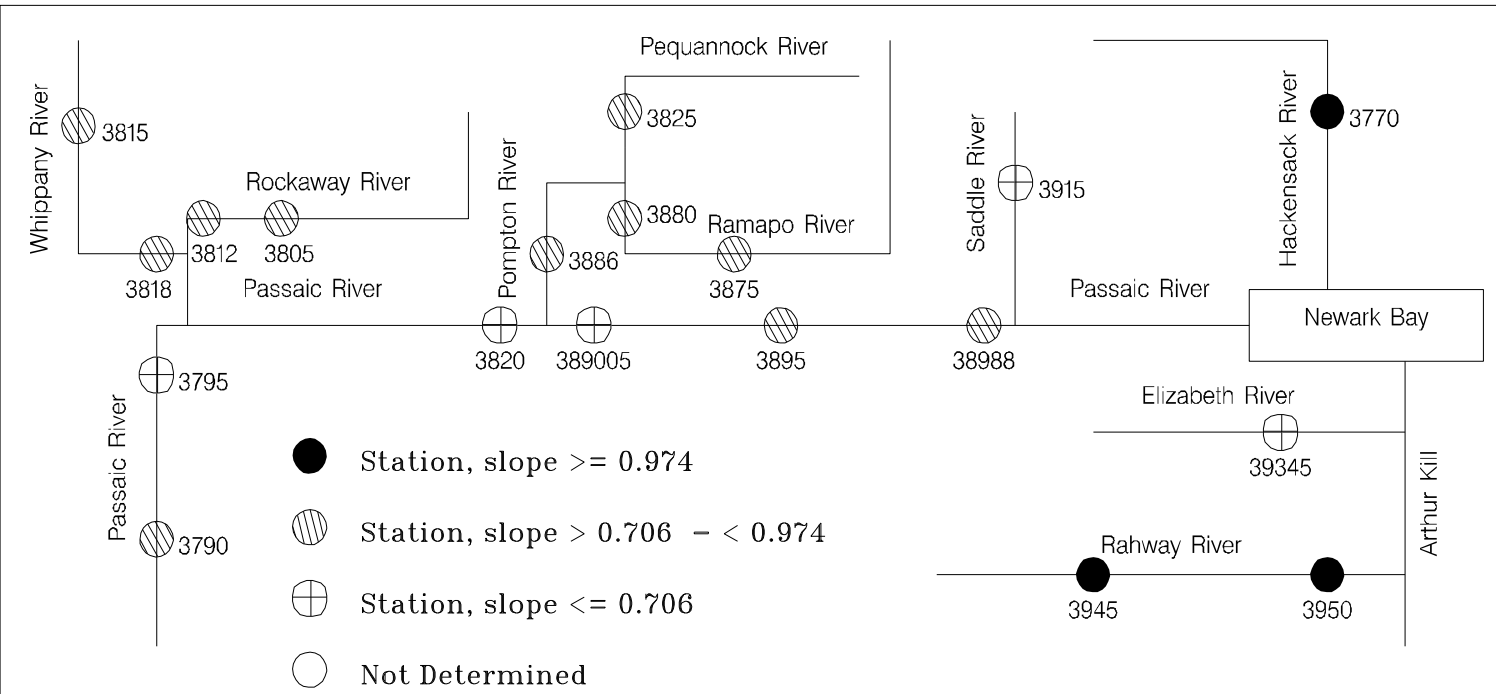

Figure 14. Trends in dissolved sodium concentrations during $(A)$ high- and $(B)$ lowflow conditions, and $(\mathrm{C})$ relative slope of dissolved sodium load to streamflow at surfacewater-quality stations in the Hackensack, Passaic, Elizabeth, and Rahway River Basins, N.J., water years 1976-93. 
upper Passaic River (3820), the upstream station on the Ramapo River (3875), station 3895 on the lower Passaic River, and the one station on the Saddle River (3915) (fig. 14b). Hay and Campbell (1990) reported positive trend in dissolved sodium for the Hackensack, Whippany, and Rahway Rivers during a 7-year study period (water years 1980-86).

\section{$\underline{\text { Relation of load to streamflow }}$}

The range categories of regression slopes of dissolved sodium load to streamflow are depicted in figure 14c. The slopes range from 0.573 at station 3795 on the upper Passaic River (table 7a) to 1.107 at station 3945 on the Rahway River (table 22a). The slopes are in the high range at the one station on the Hackensack River (3770) and both stations on the Rahway River (3945 and 3950) where the contributions to instream sodium loads from storm runoff are larger and less influenced by point sources and ground water than at other sites in the study area. The slopes are in the low range at the downstream stations on the upper Passaic River (3795 and 3820), the upstream station on the lower Passaic River (389005), and the one station on the Saddle River (3915). At these sites, the contributions to instream sodium loads from point sources and ground water are larger and less influenced by storm runoff than at other sites in the study area.

\section{Dissolved Chloride}

Chloride is present in all surface water, but usually in low $(<10 \mathrm{mg} / \mathrm{L})$ concentrations. Chloride ions do not significantly enter into oxidation or reduction reactions, form no important solute complexes with other ions unless the chloride concentration is extremely high, do not form salts of low solubility, are not significantly adsorbed onto mineral surfaces, and play few vital biochemical roles (Hem, 1985). Conservative constituents such as chloride move through a stream system mainly by physical processes (water inputs and withdrawals). Chloride is present in various rock types in concentrations lower than that of any of the other major constituents of ambient water. In most streams, chloride concentrations are smaller than those of sulfate or bicarbonate. Exceptions occur where streams receive inflows of ground water or industrial wastewater containing large concentrations of chloride, or are affected by oceanic tides. Chloride salts used for deicing highways can be carried to surface water by storm runoff and melting snow.

\section{$\underline{\text { Relation of trends in concentration to flow conditions }}$}

The trends in chloride concentrations during high flows are positive at the downstream stations on the Rockaway (3812) and Whippany (3818) Rivers and the one station on the Saddle River (3915), indicating an increase in the contribution from storm runoff over time at these sites (fig. 15a). Chloride concentrations during high flows show no trends at any of the stations on the upper Passaic River (3790, 3795, and 3820), the upstream station on the Whippany River (3815), and station 3895 on the lower Passaic River. The trends in chloride concentrations during low flows are positive at the downstream station on the upper Passaic River (3820), station 3895 on the lower Passaic, and the one station on the Saddle River (3915), indicating an increase in the contributions from point sources and ground water over time at these sites (fig. 15b). Chloride concentrations during low flows show no trend at the upstream station on the Ramapo River 
(A)

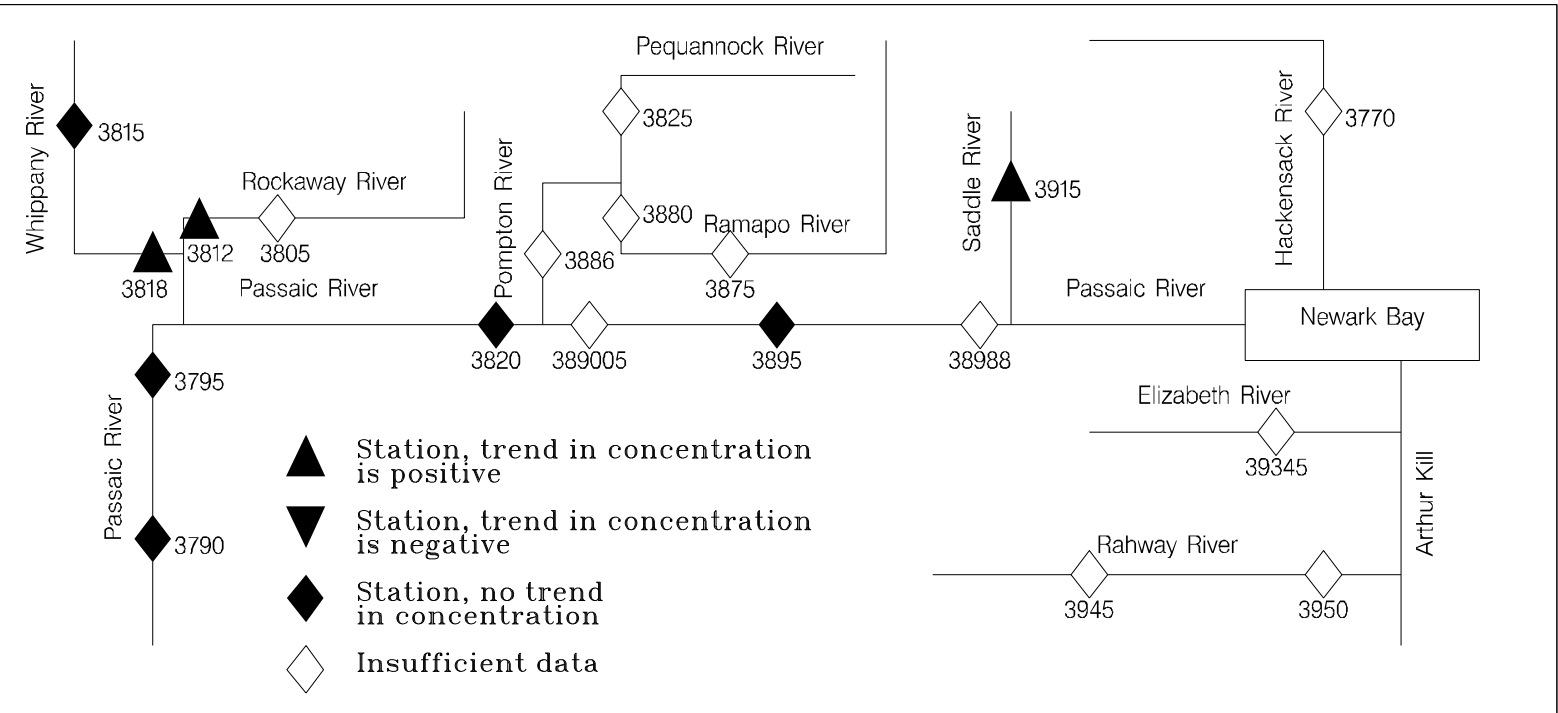

(B)

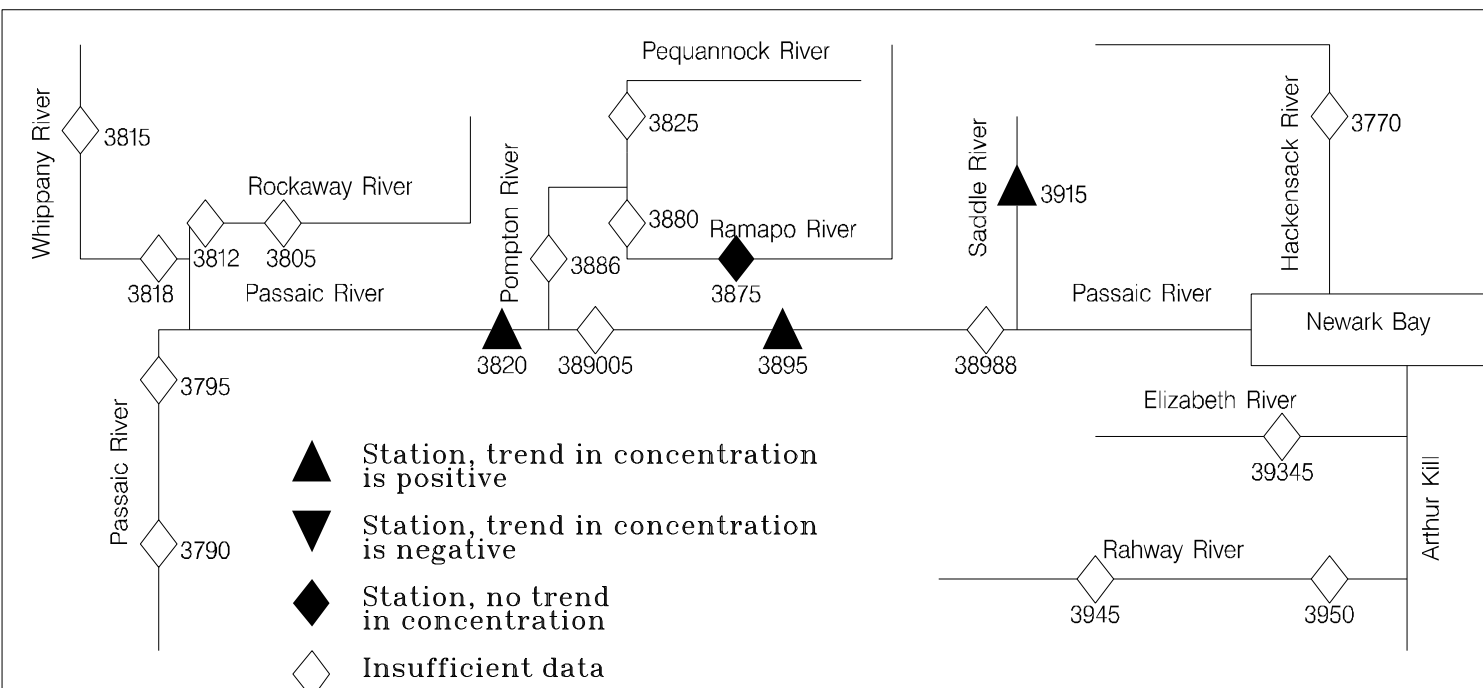

(C)

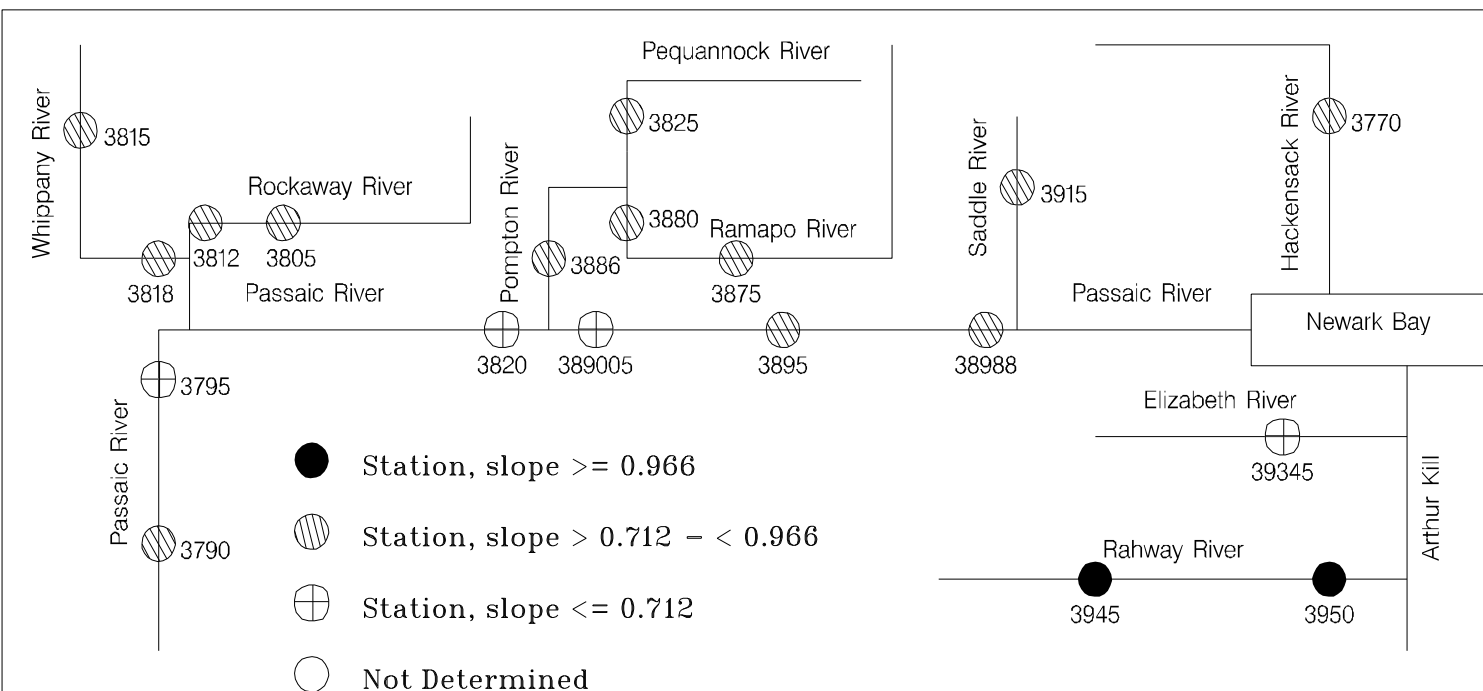

Figure 15. Trends in dissolved chloride concentrations during (A) high- and (B) lowflow conditions, and $(C)$ relative slope of dissolved chloride load to streamflow at surfacewater-quality stations in the Hackensack, Passaic, Elizabeth, and Rahway River Basins, N.J., water years 1976-93. 
(3875). Hay and Campbell (1990) reported positive trends for chloride in the area of the Hackensack, Saddle, Passaic, Rockaway, Whippany, and Rahway Rivers during a 7-year study period (water years 1980-86).

\section{$\underline{\text { Relation of load to streamflow }}$}

The range categories of regression slopes of chloride load to streamflow are depicted in figure 15c. The slopes range from 0.584 at station 39345 on the Elizabeth River (table 21a) to 1.094 at station 3950 on the Rahway River (table 23a). The slopes are in the high range at both stations on the Rahway River (3945 and 3950) where the contributions to instream chloride loads from storm runoff are larger and less influenced by point sources and ground water than at other sites in the study area. The slopes are in the low range at the downstream stations on the upper Passaic River (3795 and 3820), the upstream station on the lower Passaic River (389005), and the one station on the Elizabeth River (39345). At these sites, the contributions to instream chloride loads from point sources and ground water are larger and less influenced by storm runoff than at other sites in the study area.

\section{Dissolved Oxygen}

Dissolved oxygen (DO) concentrations in surface water depend on the physical, chemical, and biochemical activities occurring in the water body and are a function of water temperature, atmospheric pressure, and concentrations of other solutes. The higher forms of aquatic life require oxygen for survival, and the measurement of DO is used widely to evaluate the biochemistry of surface water (Hem, 1985). Photosynthesis and water turbulence are important mechanisms that replenish DO consumed by organic matter. Oxygen supersaturation can occur in slow moving systems in winter and when photosynthesizing biota are abundant during the summer. The presence of organic compounds in surface water can cause oxygen demand. Positive trends and steeper slopes of load to streamflow can indicate improved water quality.

\section{$\underline{\text { Relation of trends in concentration to flow conditions }}$}

The trend in dissolved oxygen concentration during high flows is positive at the downstream station on the Whippany River (3818) (fig. 16a). Dissolved-oxygen concentrations during high flows show no trend at all stations on the upper Passaic and Rockaway Rivers, the upstream station on the Whippany River (3815), the downstream stations on the lower Passaic River (3895 and 38988), and the one station on the Saddle River (3915). The trends in dissolved oxygen concentrations during low flows are positive at the downstream station on the upper Passaic River (3820) and the upstream station on the Ramapo River (3875) (fig. 16b). Dissolvedoxygen concentrations during low flows show no trend at the upstream station on the Rockaway River (3805), station 3895 on the lower Passaic River, and the one station on the Saddle River (3915). 
(A)

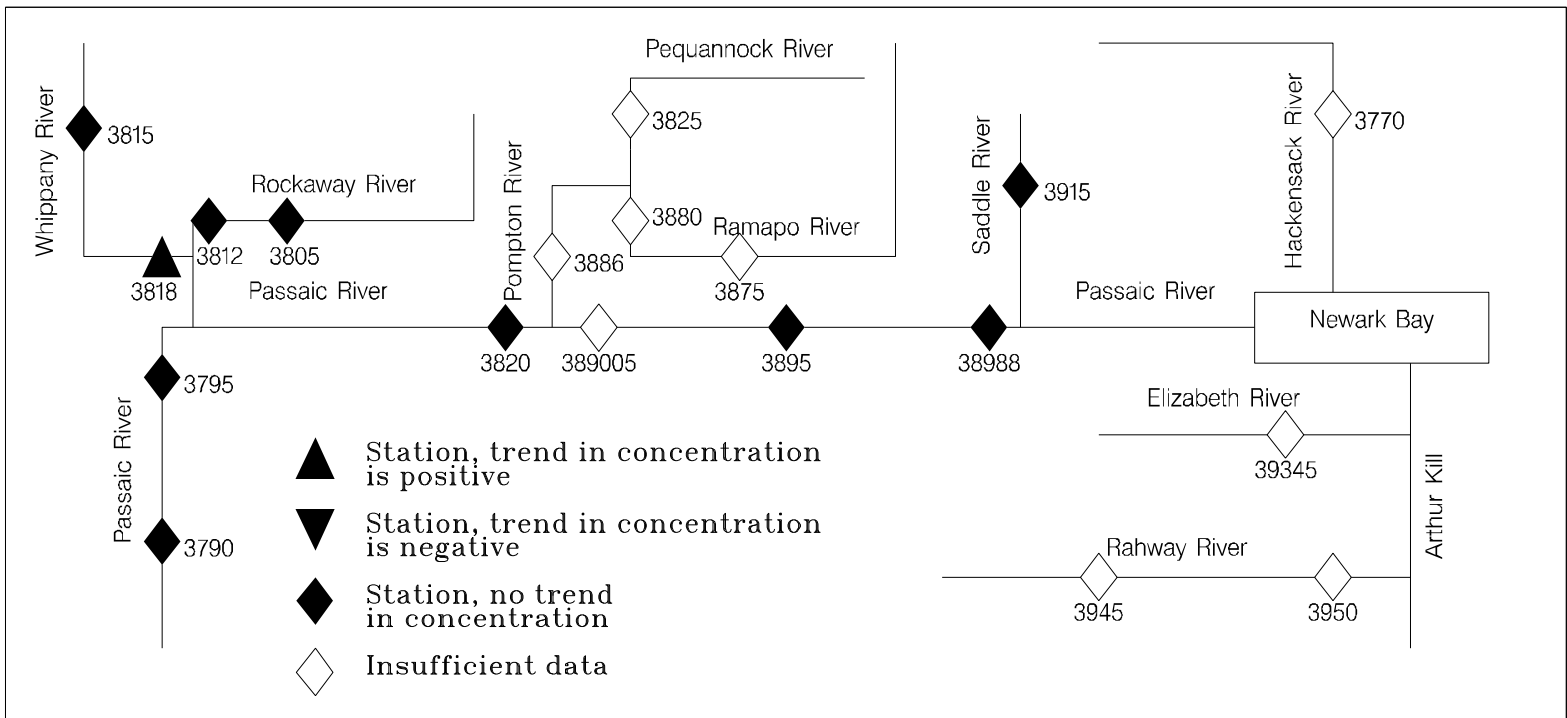

(B)

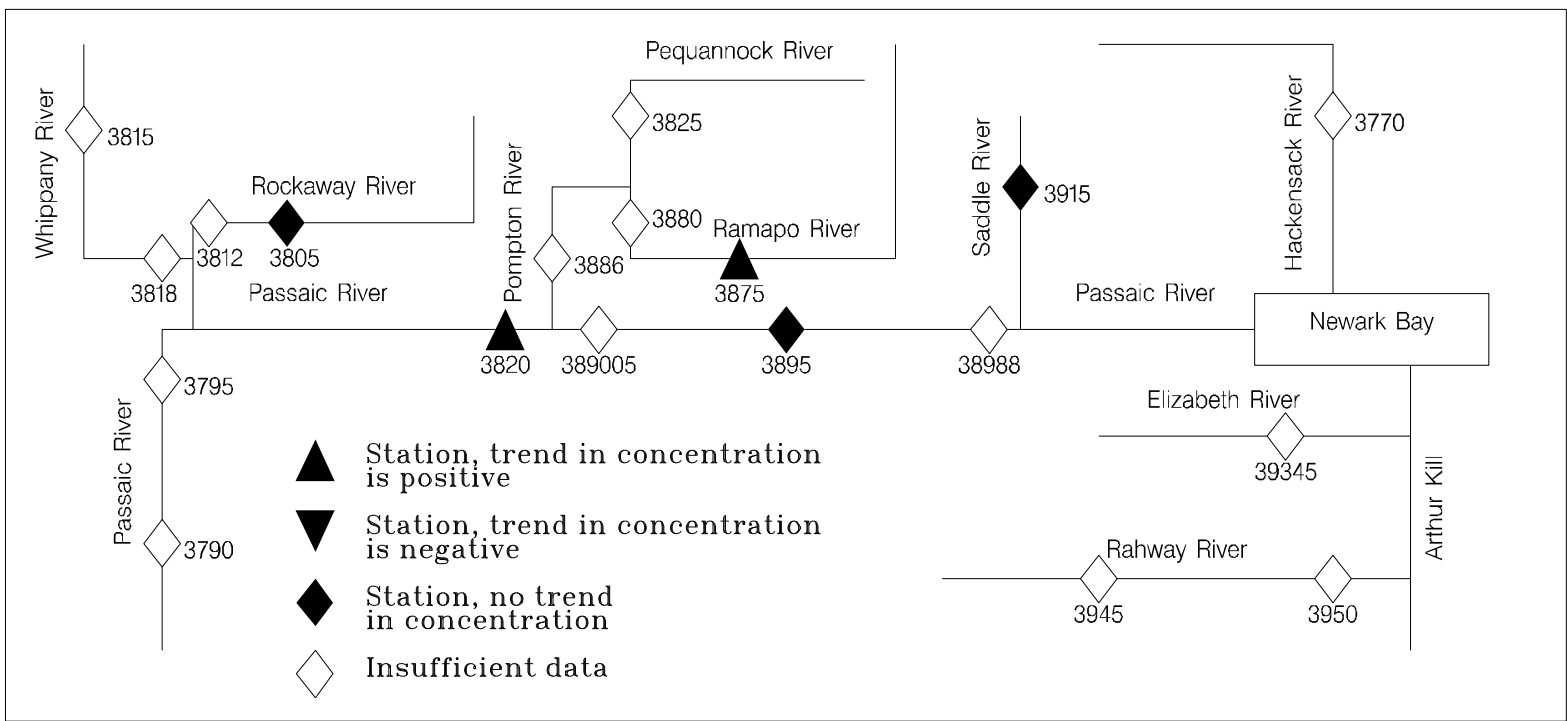

(C)

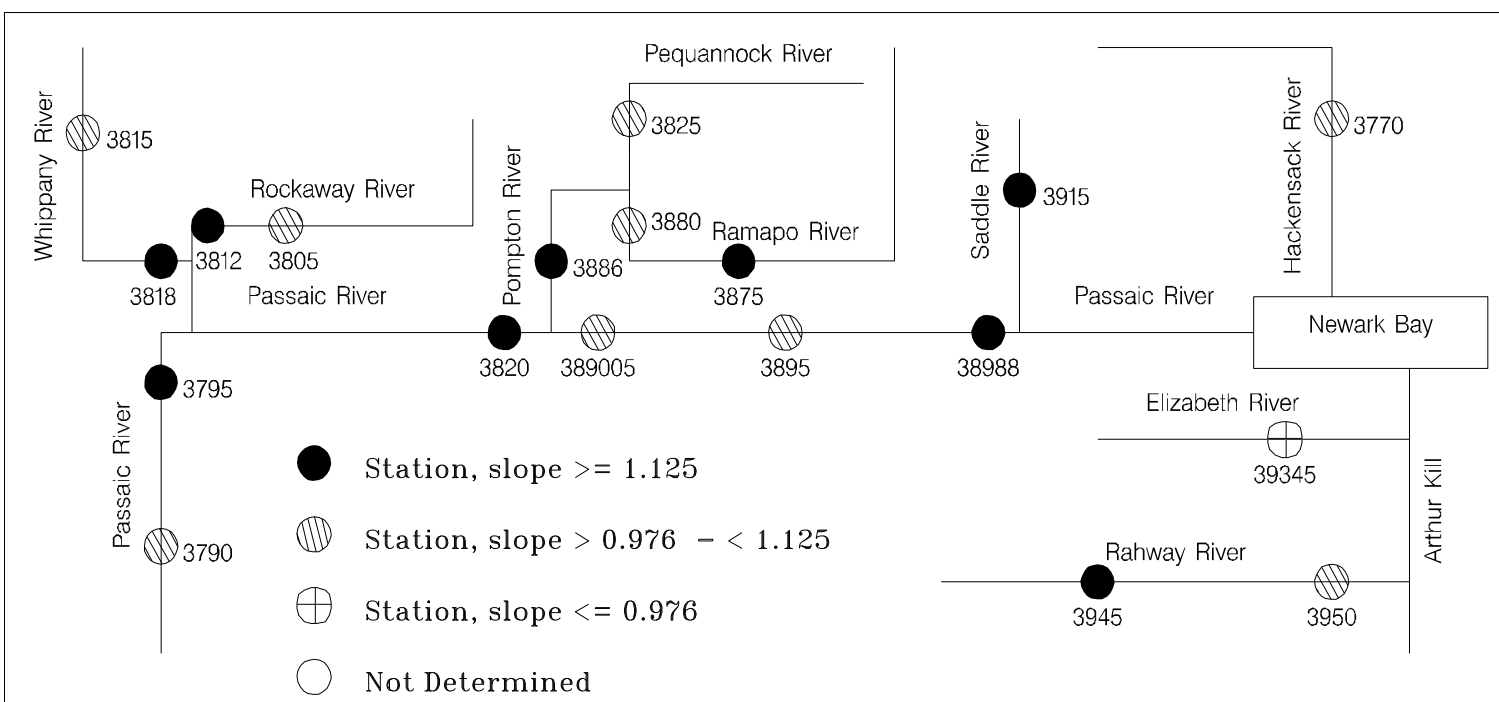

Figure 16. Trends in dissolved oxygen concentrations during $(A)$ high- and $(B)$ lowflow conditions, and $(C)$ relative slope of dissolved oxygen load to streamflow at surface-water-quality stations in the Hackensack, Passaic, Elizabeth, and Rahway River Basins, N.J., water years 1976-93. 


\section{Relation of load to streamflow}

The range categories of regression slopes of dissolved-oxygen load to streamflow are depicted in figure 16c. The range of slopes is narrow, ranging from 0.902 at station 39345 on the Elizabeth River (table 21a) to 1.200 at station 3812 on the Rockaway River (table 10a). The slopes are in the high range at the downstream stations on the upper Passaic (3795 and 3820), Rockaway (3812), and Whippany (3818) Rivers, the upstream station on the Ramapo River (3875), the one station on the Pompton River (3886), the downstream station on the lower Passaic River (38988), the one station on the Saddle River (3915), and the upstream station on the Rahway River (3945). The slope at the one station on the Elizabeth River (39345) is in the low range.

\section{Fraction of Dissolved Oxygen at Saturation}

The fraction of dissolved oxygen at saturation is the ratio of the measured DO concentration to the maximum DO concentration possible in the water. The maximum DO concentration possible is a function of atmospheric pressure, water temperature, and specific conductance of the water sample. Values are determined from published equations. The calculation of the fraction of dissolved oxygen at saturation removes the effect of temperature on oxygen solubility so that the effects of photosynthesis on DO concentration are easier to evaluate. Loads of percent dissolved-oxygen saturation were not calculated.

\section{$\underline{\text { Relation of trends in concentration to flow conditions }}$}

The trends in the fraction of dissolved oxygen at saturation during high flows are positive at station 3795 on the upper Passaic River and the downstream station on the Rockaway River (3812). No trends are apparent at the downstream stations on the upper Passaic River (3790 and 3820), the upstream station on the Rockaway River (3805), both stations on the Whippany River (3815 and 3818), station 3895 on the lower Passaic River, and the one station on the Saddle River (3915) (fig. 17a). The trends in the fraction of dissolved oxygen at saturation during low flows are positive at the downstream station on the upper Passaic River (3820) and station 3895 on the lower Passaic River. No trends are apparent at the upstream stations on the Rockaway (3805) and Ramapo (3875) Rivers and the one station on the Saddle River (3915) (fig. 17b).

\section{Total Phosphorus}

Phosphorus is present in surface water as orthophosphates, condensed phosphates (pyro-, meta-, and other polyphosphates), and organically bound phosphates (Sawyer and McCarty, 1978). Phosphates are found in solution, associated with particles, and in detritus and the bodies of aquatic organisms. They are derived from a variety of sources and are relatively immobile in soils and sediments (Hem, 1985). Phosphorus is a common element in igneous rock and is fairly abundant in sediment. Orthophosphates applied to agricultural or residential land as fertilizers can be carried into surface water by storm runoff. Phosphorus is an essential nutrient and can limit the primary productivity of a water body. Primary productivity is a measure of the rate at which new organic matter is formed and accumulated through the photosynthetic and chemosynthetic activity of producer organisms (chiefly green plants) (Bauersfeld and others, 
(A)

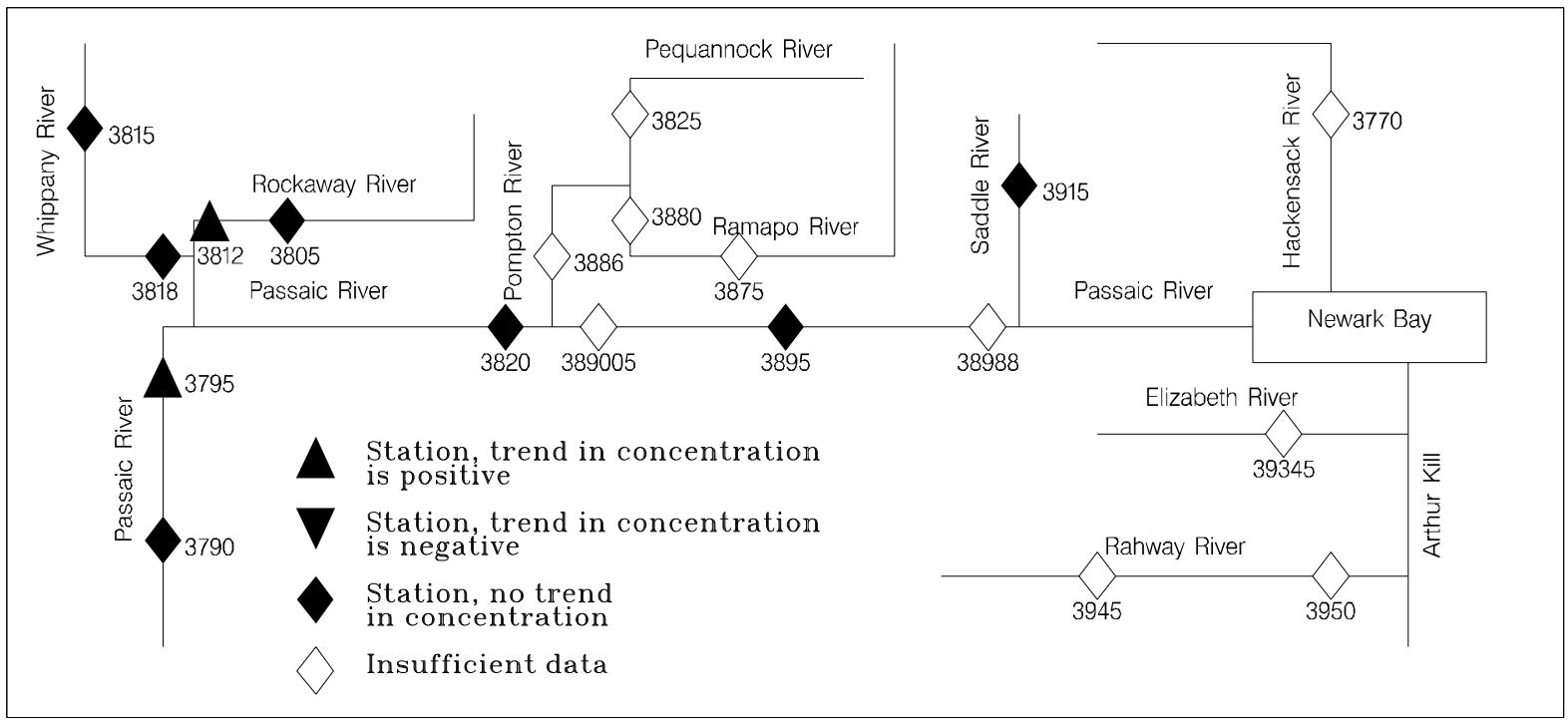

(B)

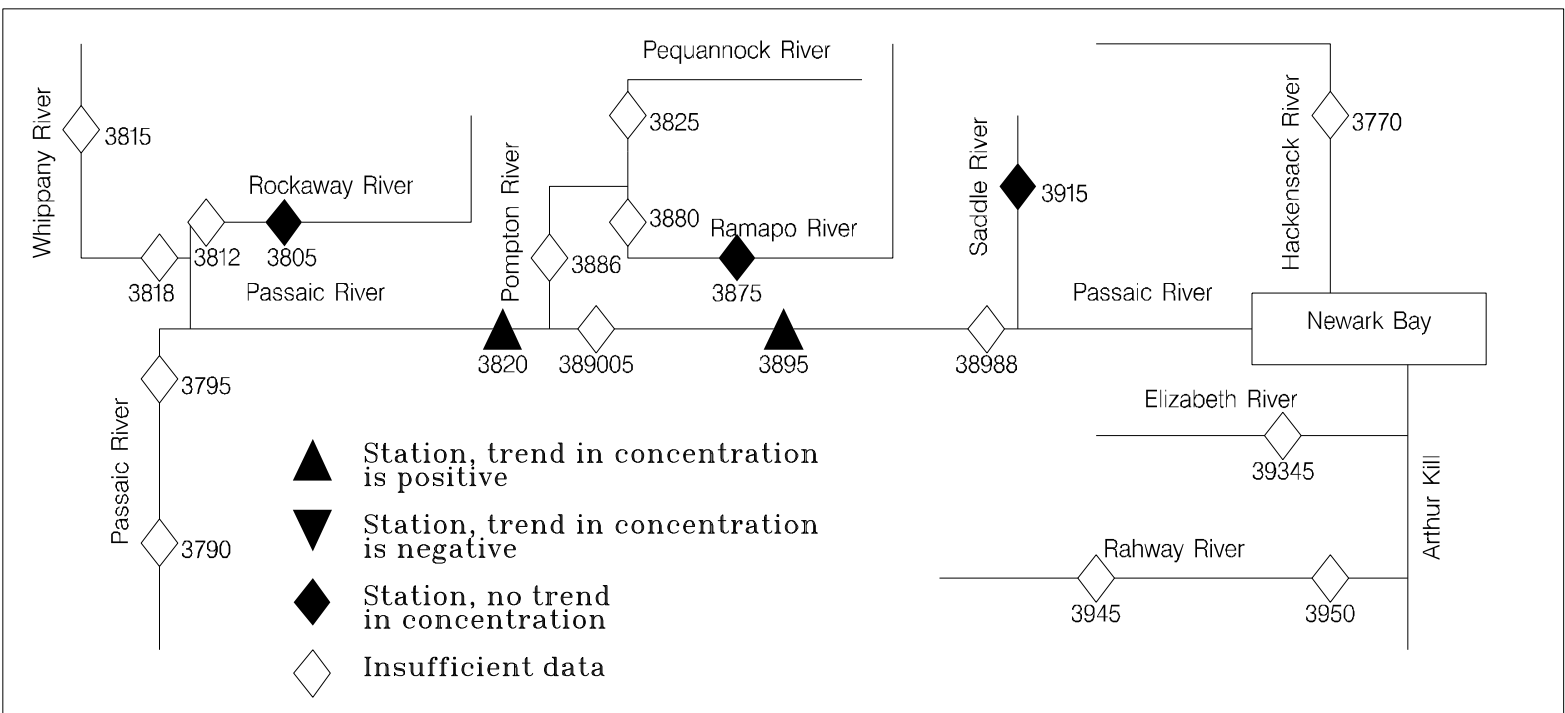

Figure 17. Trends in fraction of dissolved oxygen at saturation concentrations during (A) high- and (B) low-flow conditions, at surface-water-quality stations in the Hackensack, Passaic, Elizabeth, and Rahway River Basins, N.J., water years 1976-93. 
1994). The addition of phosphorus to surface water from storm runoff and the discharge of treated waste-water, agricultural drainage, or certain industrial wastes to the water can stimulate the growth of photosynthetic aquatic micro- and macro-organisms in nuisance quantities.

\section{$\underline{\text { Relation of trends in concentration to flow conditions }}$}

The concentrations of total phosphorus show no trends during high flows at stations 3795 on the upper Passaic and 3915 on the Saddle Rivers (fig. 18a) or low flows at station 3915 on the Saddle River (fig. 18b).

\section{$\underline{\text { Relation of load to streamflow }}$}

The range categories of regression slopes of total phosphorus load to streamflow are depicted in figure 18c. The slopes range from 0.275 at station 3812 on the Rockaway River (table 10a) to 1.168 at station 39345 on the Elizabeth River (table 21a). The slopes are in the high range at the one station on the Hackensack River (3770), the upstream station on the Rockaway River (3805), the downstream station on the Ramapo River (3880), the one station on the Elizabeth River (39345), and the downstream station on the Rahway River (3950). At these sites, the contributions to instream total phosphorus loads from storm runoff are larger and less influenced by point sources and ground water than at other sites in the study area. Slopes are in the low range at the downstream stations on the Rockaway (3812), Whippany (3818), and Passaic (3820) Rivers; the upstream station on the lower Passaic River (389005); and the one station on the Saddle River (3915). At these sites, the contributions to instream total phosphorus loads from point sources and ground water are larger and less influenced by storm runoff than at other sites in the study area. Slopes at stations on the Rockaway River decrease in the downstream direction, indicating a decrease in the contributions from storm runoff along the river. It is possible that Boonton Reservoir, located between the two stations, acts as a sink, and phosphorus is detained in the reservoir. Slopes at stations on the Ramapo and Rahway Rivers increase in the downstream direction, indicating an increase in the contributions from storm runoff along the rivers.

\section{Total Nitrogen}

Nitrogen is an essential element for plant and animal growth; however, sufficiently large concentrations of certain nitrogen species can adversely affect the quality of surface water by causing excess algal growth (eutrophication) or toxicity to aquatic and terrestrial animals. Important forms of nitrogen in surface water are, in order of decreasing oxidation state, nitrate, nitrite, ammonia, and organic nitrogen. The cycling of nitrogen is controlled mainly by biological processes. Nitrogen enters aquatic environments from fertilizers, agricultural wastes, decomposition of organic matter, atmospheric deposition, biotic fixation, and ambient soils and rocks. Ground water and storm runoff are important sources of nitrate and ammonia to surface water. High concentrations of nitrate and nitrite can reduce the oxygen-carrying capacity of hemoglobin in warm-blooded animals. Un-ionized ammonia can be toxic to aquatic organisms. 
(A)
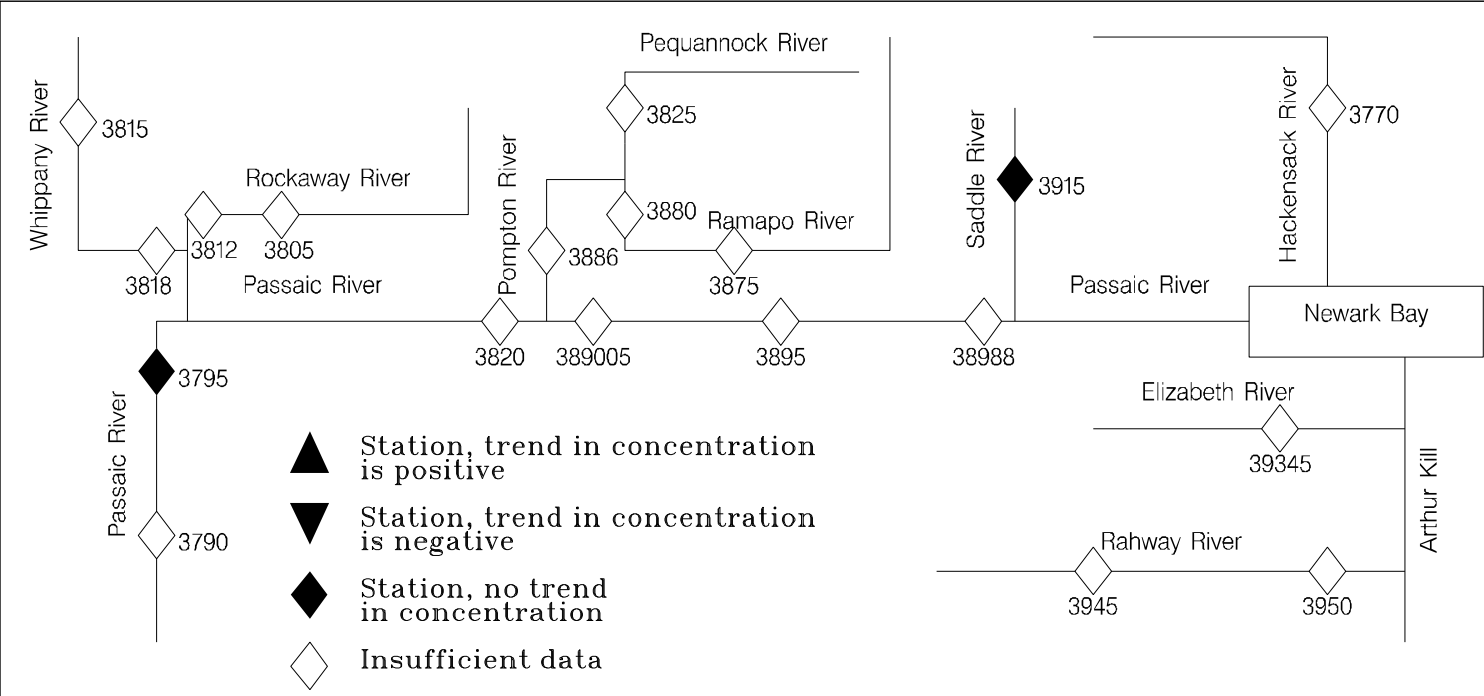

(B)

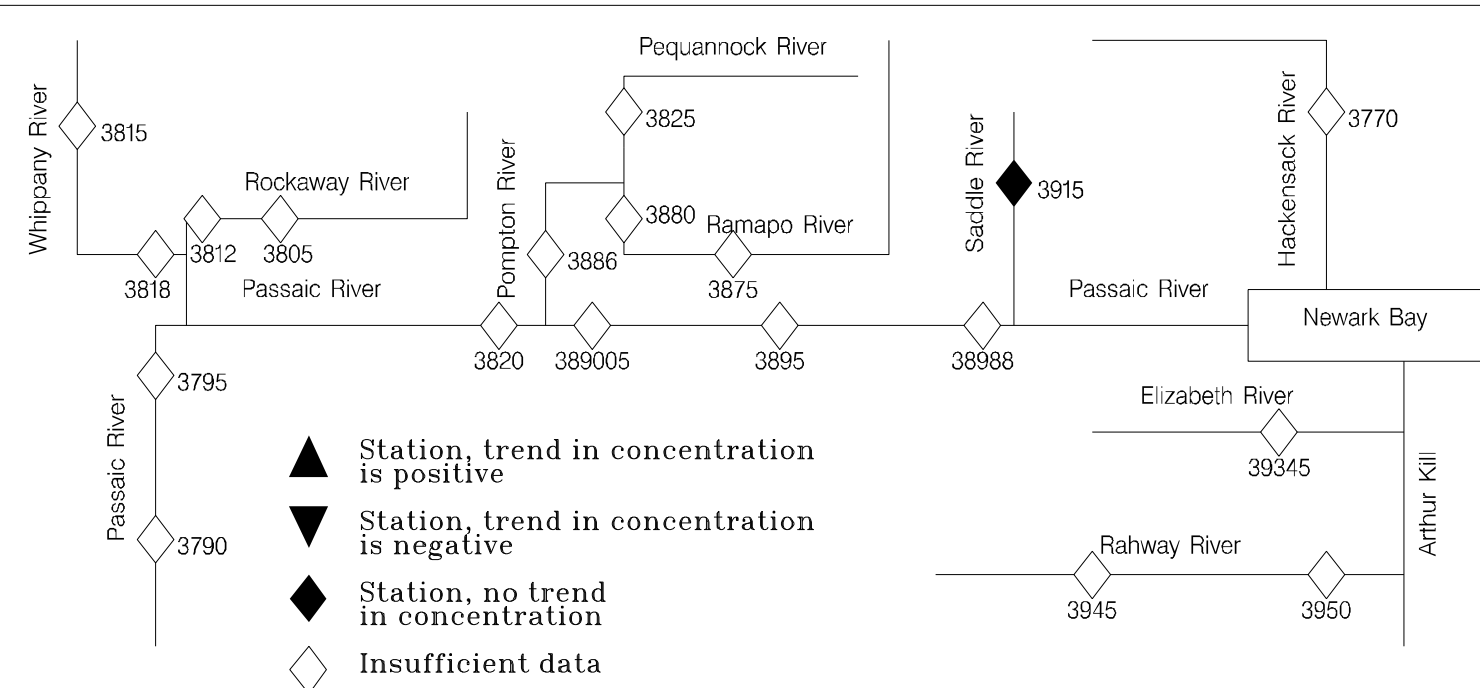

(C)

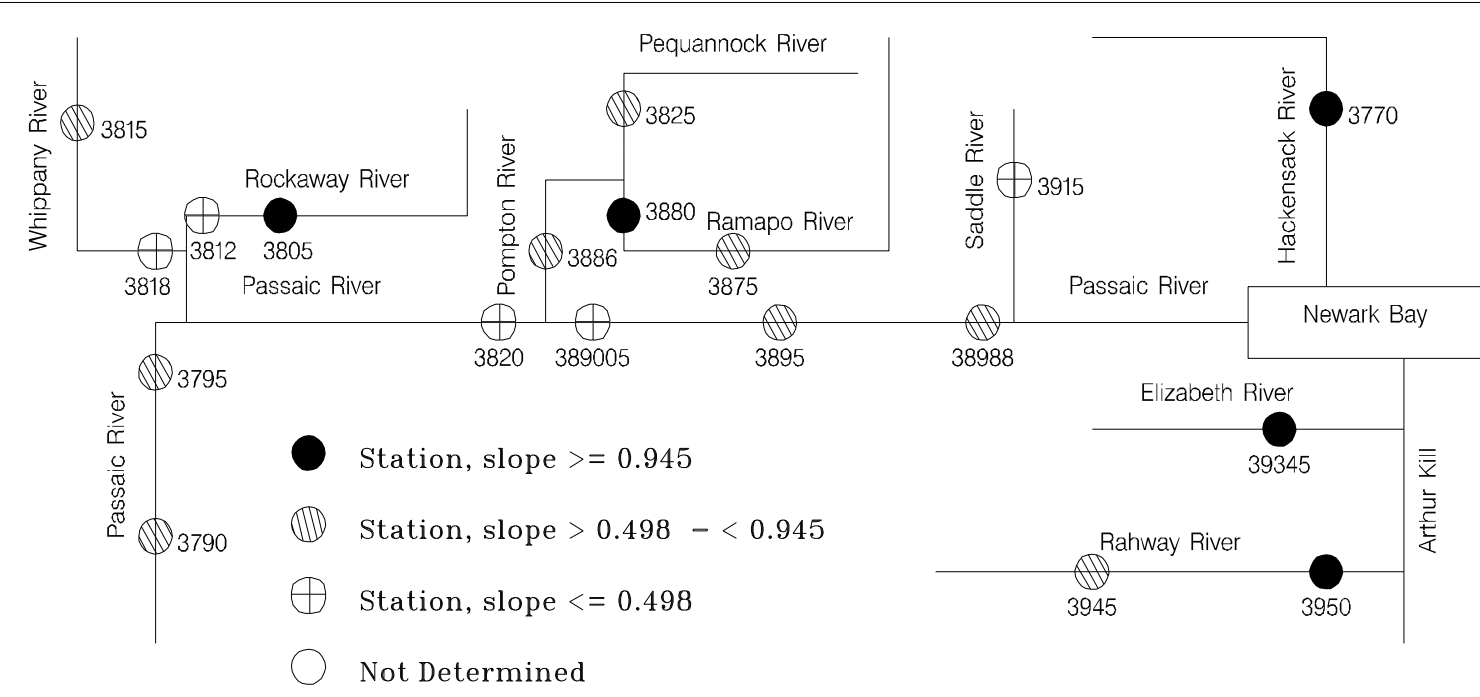

Figure 18. Trends in total phosphorus concentrations during $(A)$ high- and $(B)$ lowflow conditions, and $(\mathrm{C})$ relative slope of total phosphorus load to streamflow at surfacewater-quality stations in the Hackensack, Passaic, Elizabeth, and Rahway River Basins, N.J., water years 1976-93. 


\section{$\underline{\text { Relation of trends in concentration to flow conditions }}$}

The concentrations of total nitrogen show no trends during high flow at any of the stations on the upper Passaic (3790, 3795, and 3820) and Whippany (3815 and 3818) Rivers or the downstream stations on the lower Passaic River (3895 and 38988) (fig. 19a). During low flow, the concentrations of total nitrogen show no trends at the upstream station on the Rockaway River (3805), the downstream station on the upper Passaic River (3820), the upstream station on the Ramapo River (3875), and station 3895 on the lower Passaic River (fig. 19b).

\section{Relation of load to streamflow}

The range categories of regression slopes of total nitrogen load to streamflow are shown in figure 19c. The slopes range from 0.401 at station 3812 on the Rockaway River (table 10a) to 1.109 at station 3950 on the Rahway River (table 23a). Slopes are in the high range at the upstream stations on the upper Passaic (3790) and Rockaway (3805) Rivers, the one station on the Pequannock River (3825), the downstream station on the Ramapo River (3880), the one station on the Elizabeth River (39345), and both stations on the Rahway River (3945 and 3950). At these sites, the contributions to instream total nitrogen loads from storm runoff are larger and less influenced by point sources and ground water than at other sites in the study area. Slopes are in the low range at the downstream stations on the Rockaway (3812), Whippany (3818), and upper Passaic (3820) Rivers, and the upstream stations on the lower Passaic River (389005 and 3895). At these sites, the contributions to instream total nitrogen loads from point sources and ground water are larger and less influenced by storm runoff than at other sites in the study area. Slopes at stations on the upper Passaic and Rockaway Rivers decrease in the downstream direction, indicating a sink in the system or a decrease in the contributions from storm runoff along the rivers, whereas slopes at stations on the Ramapo River increase in the downstream direction, indicating an increase in the contributions from storm runoff.

\section{Total Nitrate Plus Nitrite}

The total oxidized nitrogen concentration is the sum of the nitrate and nitrite concentrations. Nitrite is an intermediate oxidation state of nitrogen. Nitrite is usually present in trace amounts in surface water because it is rapidly oxidized to nitrate and is generally considered to be an indicator of the presence of sewage or organic waste (low DO conditions). Nitrite can enter surface water in discharge from wastewater-treatment plants and water-reuse systems in fish culture facilities where the nitrification process to reduce ammonia concentrations is impaired (Rand and Petrocelli, 1985). Nitrite is the etiologic agent of methemoglobinemia in humans and fish. Under specific conditions, nitrite is involved in the formation of some carcinogenic nitrosamines. Nitrate is an essential nutrient for many photosynthetic autotrophs and, in some cases, has been identified as the growth-limiting nutrient. It is present generally in trace amounts in surface water, but can attain high levels in some ground-water systems (Hem, 1985). Nitrate fertilizers applied to agricultural and residential land, then carried into surface water by storm runoff and ground water, can stimulate the growth of photosynthetic aquatic micro- and macroorganisms. Nitrate is considerably less toxic to aquatic organisms than are ammonia and nitrite; however, in excess amounts $(>10 \mathrm{mg} / \mathrm{L})$, nitrate contributes to methemoglobinemia in small children and fish. 
(A)

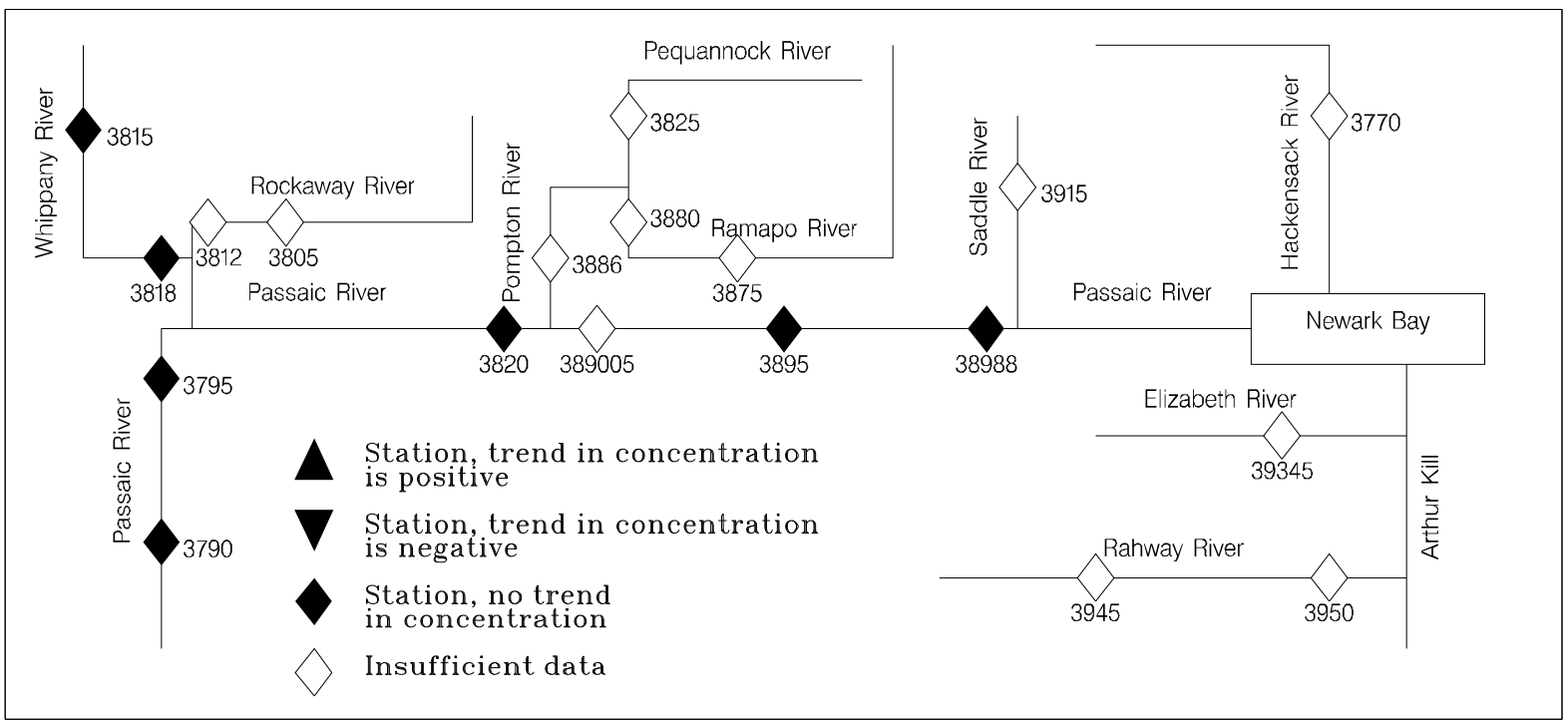

(B)

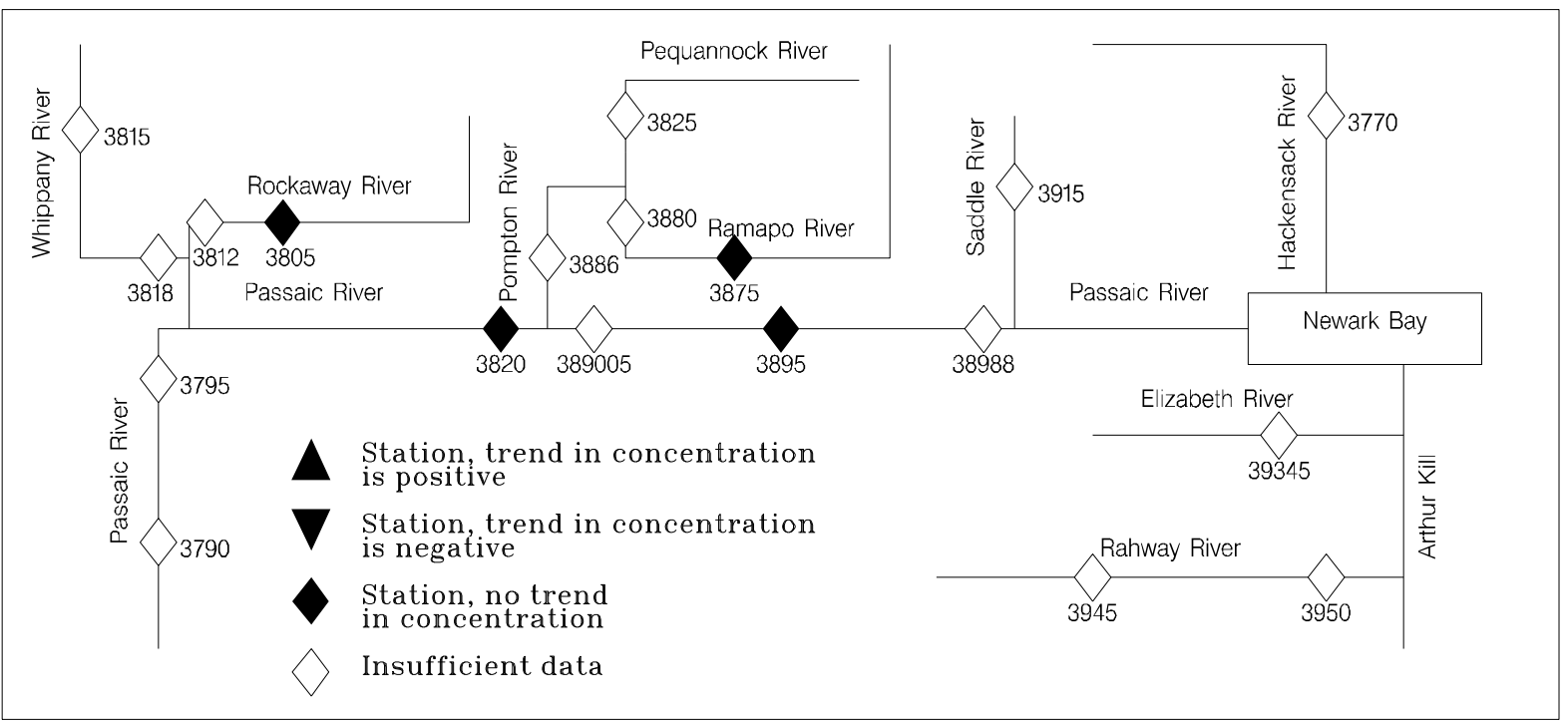

(C)

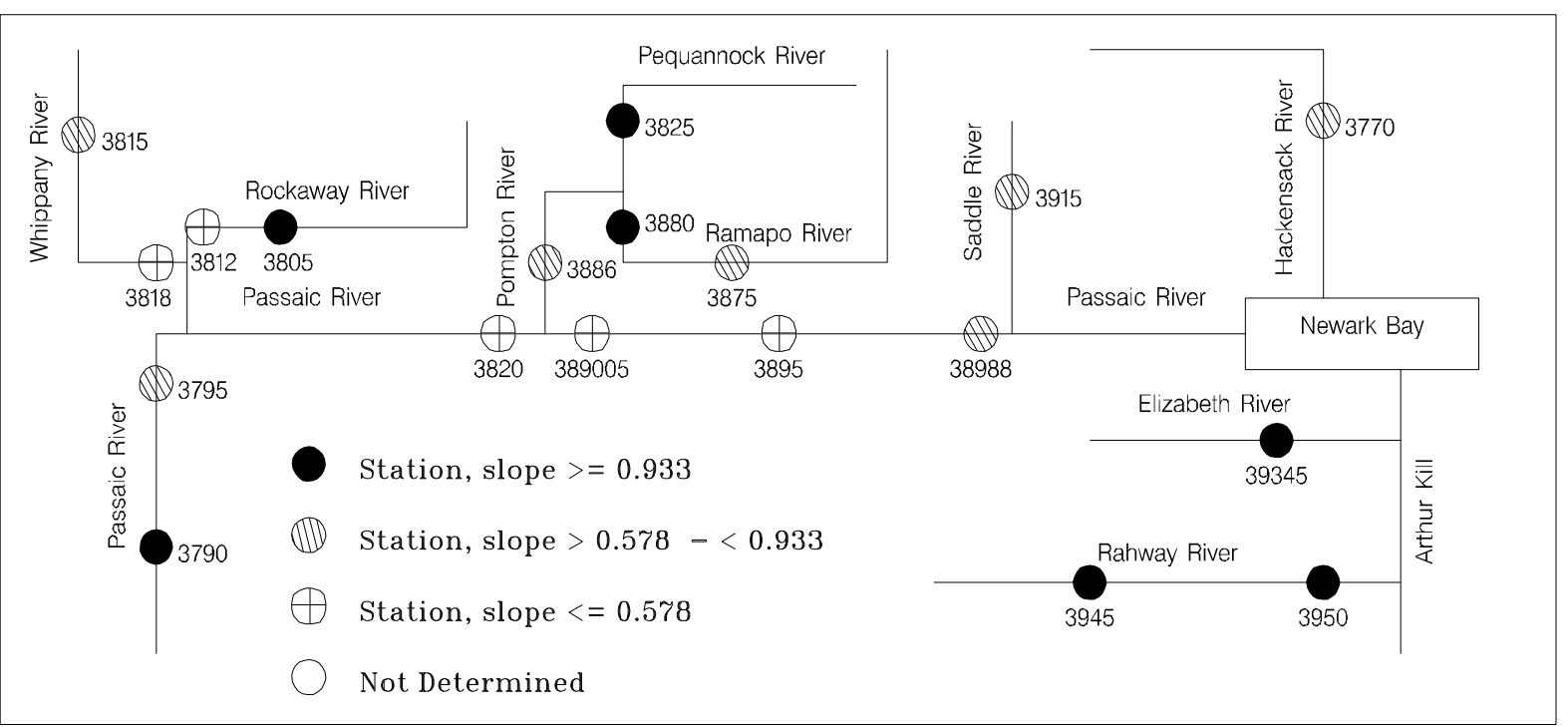

Figure 19. Trends in total nitrogen concentrations during $(A)$ high- and $(B)$ lowflow conditions, and $(\mathrm{C})$ relative slope of total nitrogen load to streamflow at surfacewater-quality stations in the Hackensack, Passaic, Elizabeth, and Rahway River Basins, N.J., water years 1976-93. 


\section{$\underline{\text { Relation of trends in concentration to flow conditions }}$}

The concentrations of total nitrate plus nitrite show no trends during high flows at any of the stations on the upper Passaic (3790, 3795, and 3820) and Whippany (3815 and 3818) Rivers and the downstream station on the lower Passaic River (38988) (fig. 20a). The trend in total nitrate plus nitrite concentrations during low flows is positive at the downstream station on the upper Passaic River (3820), indicating an increase in the contributions from point sources and ground water over time at this site (fig. 20b). Discharge from wastewater-treatment plants in which the organic nitrogen is almost entirely oxidized can result in increased nitrate plus nitrite concentrations in the receiving streams. (This wastewater treatment could also be responsible for the decrease and increase in period-of-record medians for ammonia and dissolved oxygen, respectively, compared to the 1989-93 water year medians (table 12a)). Also during low flows, the concentrations of total nitrogen show no trends at the upstream stations on the Rockaway (3805) and Ramapo (3875) Rivers and the one station on the Saddle River (3915).

\section{$\underline{\text { Relation of load to streamflow }}$}

The range categories of regression slopes of total nitrate plus nitrite load to streamflow are depicted in figure 20c. The slopes range from 0.340 at station 389005 on the lower Passaic River (table 17a) to 1.242 at station 3790 on the upper Passaic River (table 6a). Slopes are in the high range at the upstream stations on the upper Passaic (3790) and Rockaway (3805) Rivers, the one station on the Pequannock River (3825), and the downstream stations on the Ramapo (3880) and Rahway (3850) Rivers. At these sites, the contributions to instream total nitrate plus nitrite loads from storm runoff are larger and less influenced by point sources and ground water than at other sites in the study area. Slopes are in the low range at the downstream stations on the Rockaway (3812), Whippany (3818), and upper Passaic (3820) Rivers, and the upstream stations on the lower Passaic River (389005 and 3895). At these stations, the contributions to instream total nitrate plus nitrite loads from point sources and ground water are larger and less influenced by storm runoff than at other sites in the study area. Slopes at stations on the upper Passaic and Rockaway Rivers decrease in the downstream direction, indicating an decrease in the contributions from storm runoff along the rivers, whereas slopes at stations on the Ramapo and Rahway Rivers increase in the downstream direction, indicating an increase in the contributions from storm runoff along the rivers.

\section{Total Nitrite}

Nitrite is an intermediate oxidation state of nitrogen, both in the oxidation of ammonia to nitrate and in the reduction of nitrate. Nitrite species are unstable in aerated water and are generally considered to be indicators of the presence of sewage or organic waste (low DO conditions). Nitrite is the etiologic agent of methemoglobinemia. 
(A)

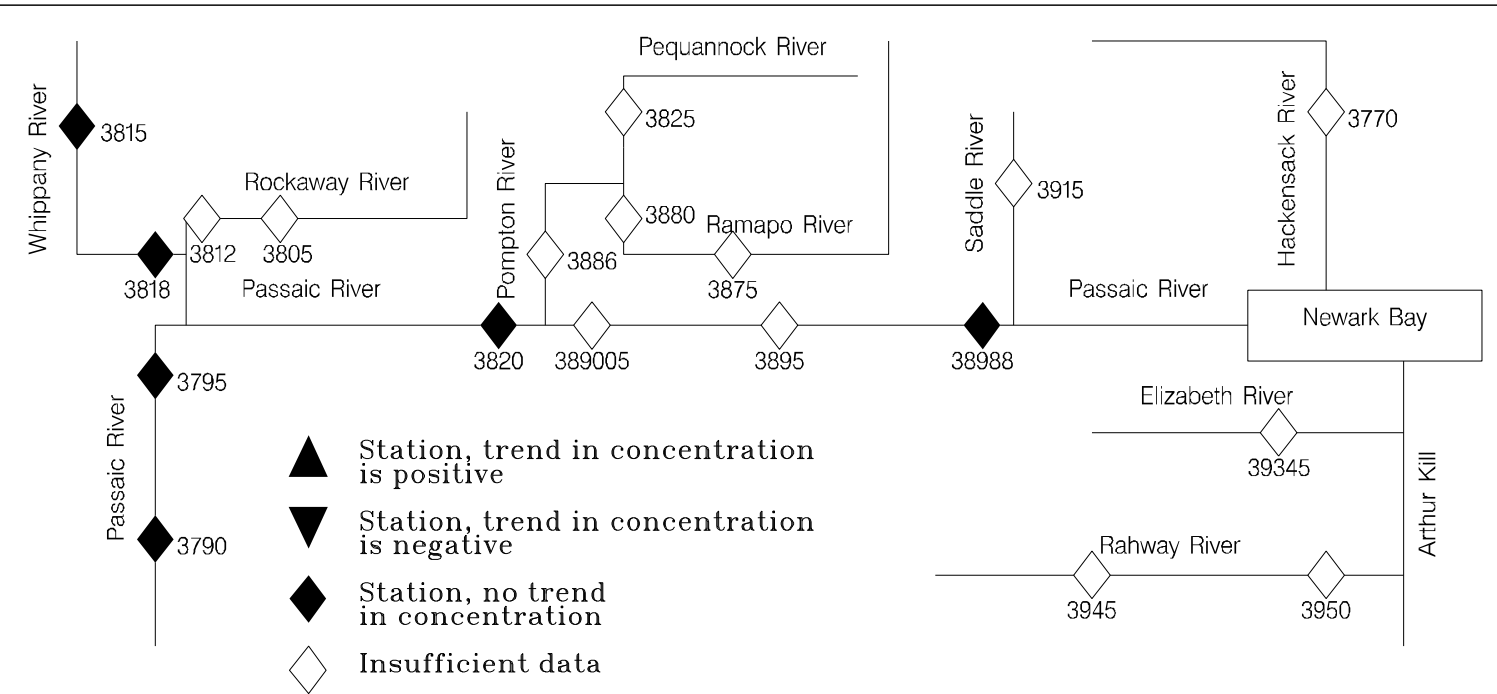

(B)

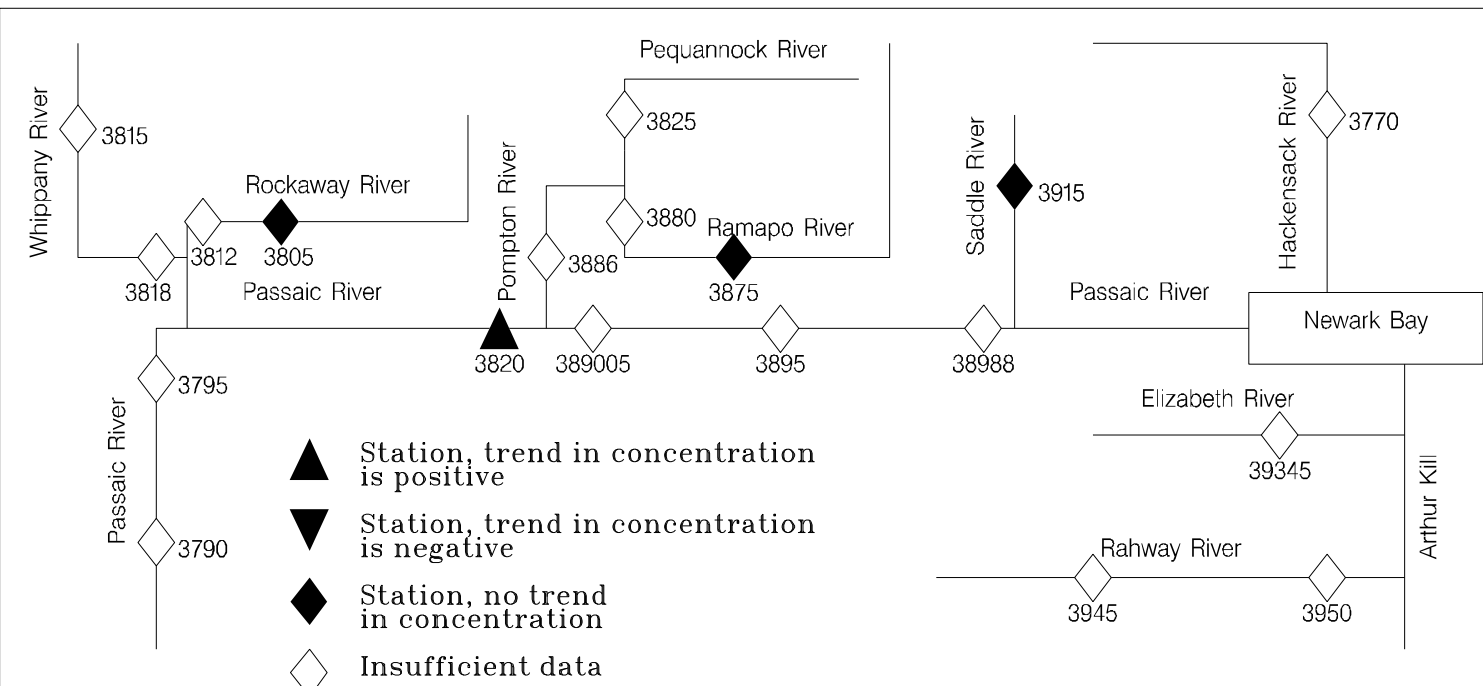

(C)

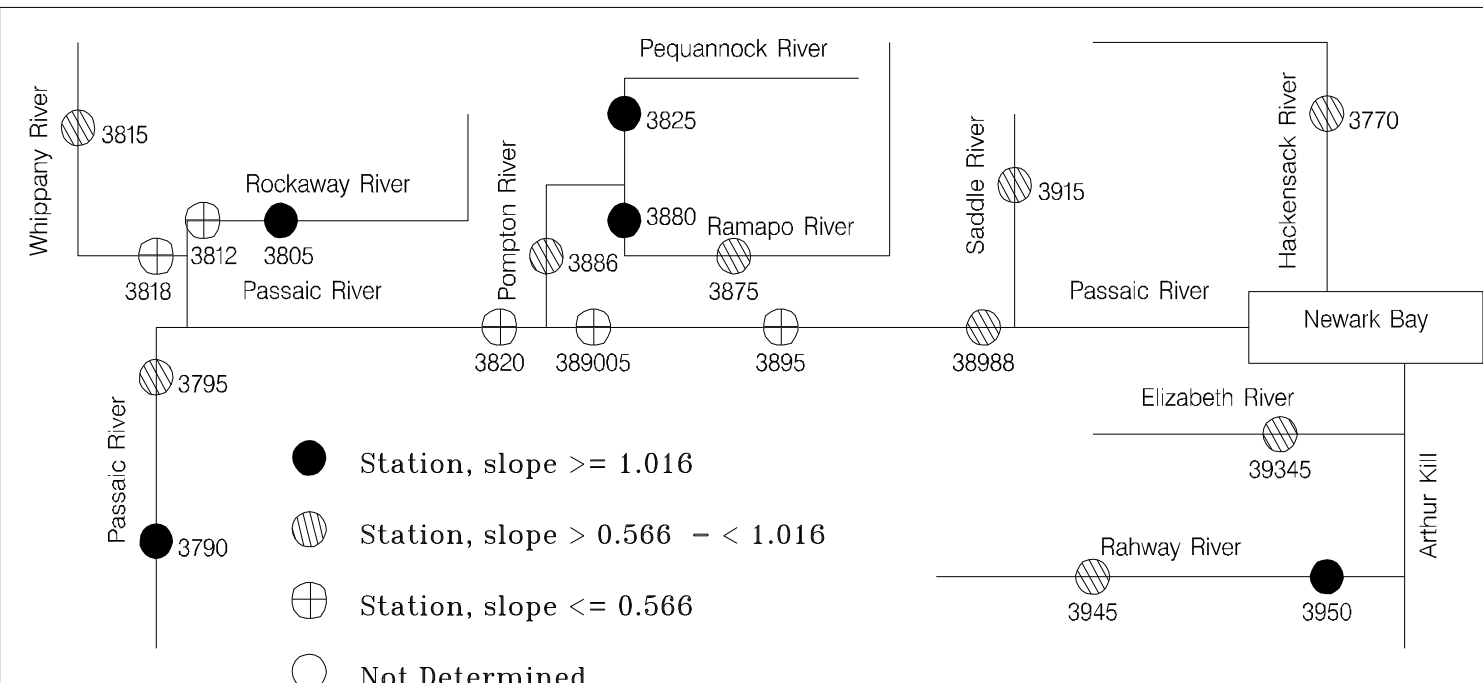

Figure 20. Trends in total nitrate plus nitrite concentrations during (A) high- and (B) lowflow conditions, and $(C)$ relative slope of total nitrate plus nitrite load to streamflow at surface-water-quality stations in the Hackensack, Passaic, Elizabeth, and Rahway River Basins, N.J., water years 1976-93. 


\section{$\underline{\text { Relation of trends in concentration to flow conditions }}$}

Insufficient data are available to determine trends in total nitrite concentrations during high flows at all stations in the study area (fig. 21a). Insufficient data are available to determine trends in total nitrite concentrations during low flows at all stations in the study area, except at the upstream station on the Rockaway River (3805) where no trend was determined (fig. 21b).

\section{Relation of load to streamflow}

The range categories of regression slopes of total-nitrite load to streamflow are depicted in figure 21c. The slopes range from zero at stations 3818 on the Whippany (table 12a) and 3915 on the Saddle Rivers (table 20a) to 1.092 at station 3950 on the Rahway River (table 23a). The slopes are in the high range at the one station on the Hackensack River (3770), the upstream stations on the upper Passaic (3790) and Rockaway (3805) Rivers, the one station on the Pequannock River (3825), the downstream station on the Ramapo River (3880), the one station on the Elizabeth River (39345), and both stations on the Rahway River (3945 and 3950). At these sites, the contributions to instream total nitrite loads from storm runoff are larger and less influenced by point sources and ground water than at other sites in the study area. The slopes are in the low range at the downstream station on the Whippany River (3818) and the one station on the Saddle River (3915). These slopes are not different from zero at the 0.05 significance level, indicating that the contributions to instream total-nitrite loads from storm runoff are extremely small. Slopes at stations on the upper Passaic and Rockaway Rivers decrease in the downstream direction, indicating an decrease in the contributions from storm runoff along the rivers, whereas slopes at stations on the Ramapo River increase in the downstream direction, indicating an increase in the contributions from storm runoff along the river.

\section{Total Ammonia Plus Organic Nitrogen}

Organic nitrogen is defined as organically bound nitrogen in the tri-negative oxidation state. It includes natural materials such as proteins and peptides, nucleic acids and urea, and numerous synthetic organic materials, but does not include all organic nitrogen compounds. Ammonia is produced by the deamination of organic nitrogen-containing compounds. Ammonia can enter surface water dissolved in wastewater effluent, storm runoff, and rain. Temperature, $\mathrm{pH}$, and ionic strength control the speciation of ammonia in surface water. The un-ionized form of ammonia is toxic to fish. The total ammonia plus organic nitrogen concentrations are determined together by the kjeldahl method (Eaton and others, 1995).

\section{$\underline{\text { Relation of trends in concentration to flow conditions }}$}

The trends in total ammonia plus organic nitrogen concentrations during high flows are negative at the downstream stations on the Rockaway (3812) and the upper Passaic (3820) Rivers and station 3915 on the Saddle River, indicating a decrease in the contribution from storm runoff over time at these stations (fig. 22a). The concentrations of total ammonia plus organic nitrogen during high flows show no trends at the two upstream stations on the upper Passaic River (3790 and 3795), both stations on the Whippany River (3815 and 3818), and the two downstream stations on the lower Passaic River (3895 and 38988). The trends in total ammonia plus organic 
(A)

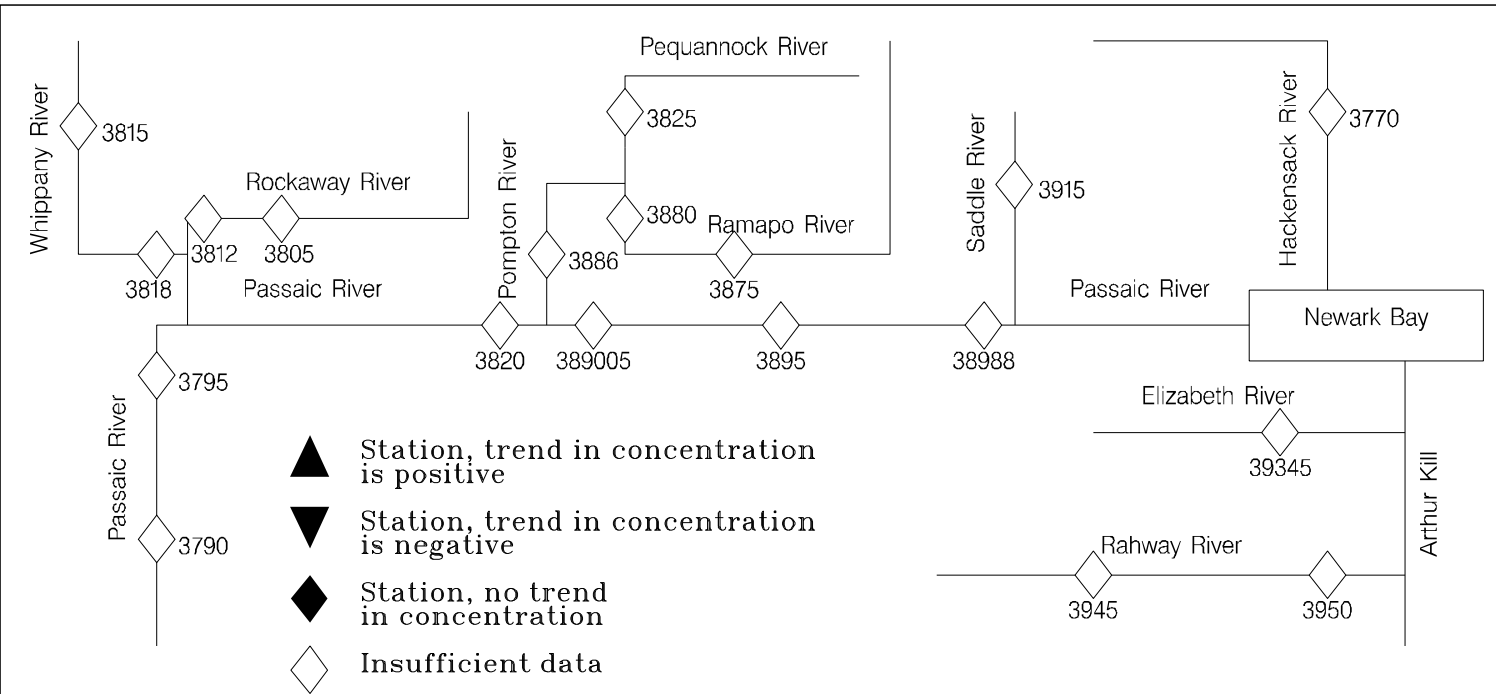

(B)

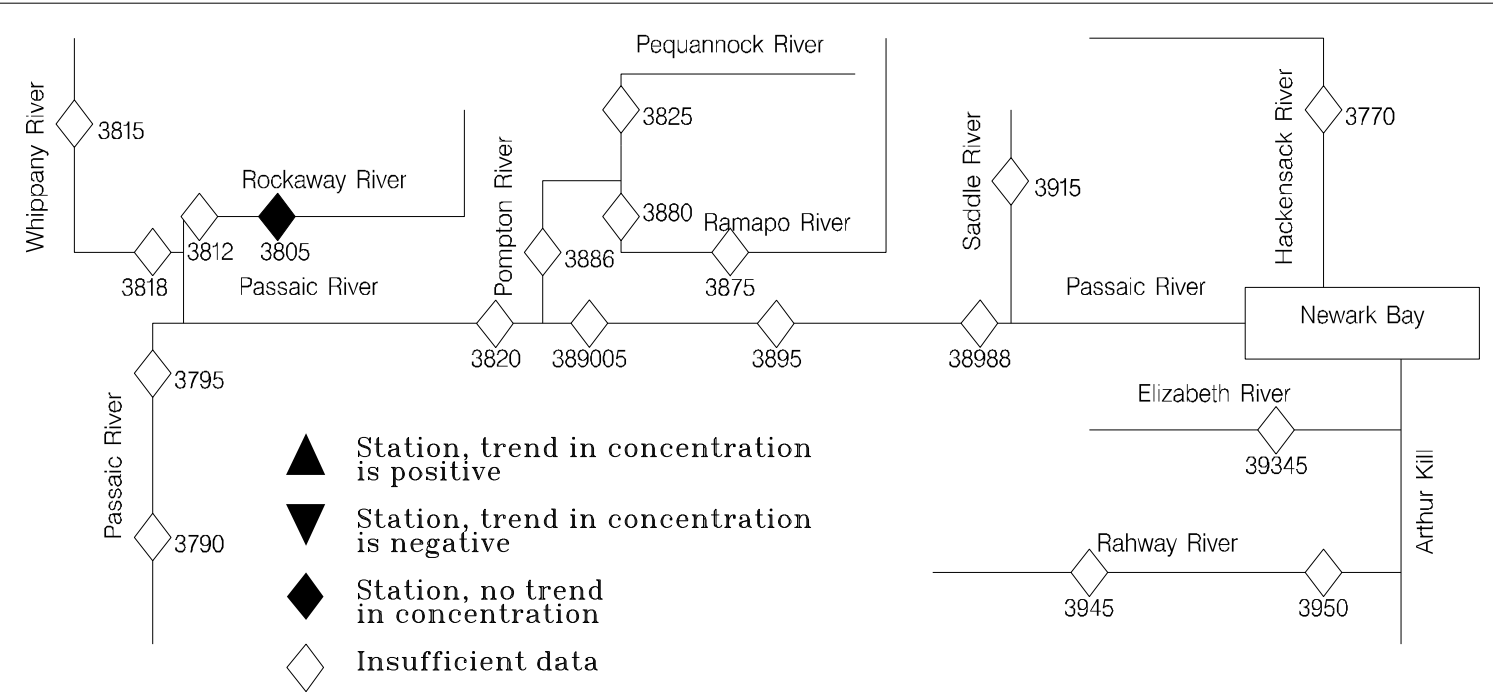

(C)

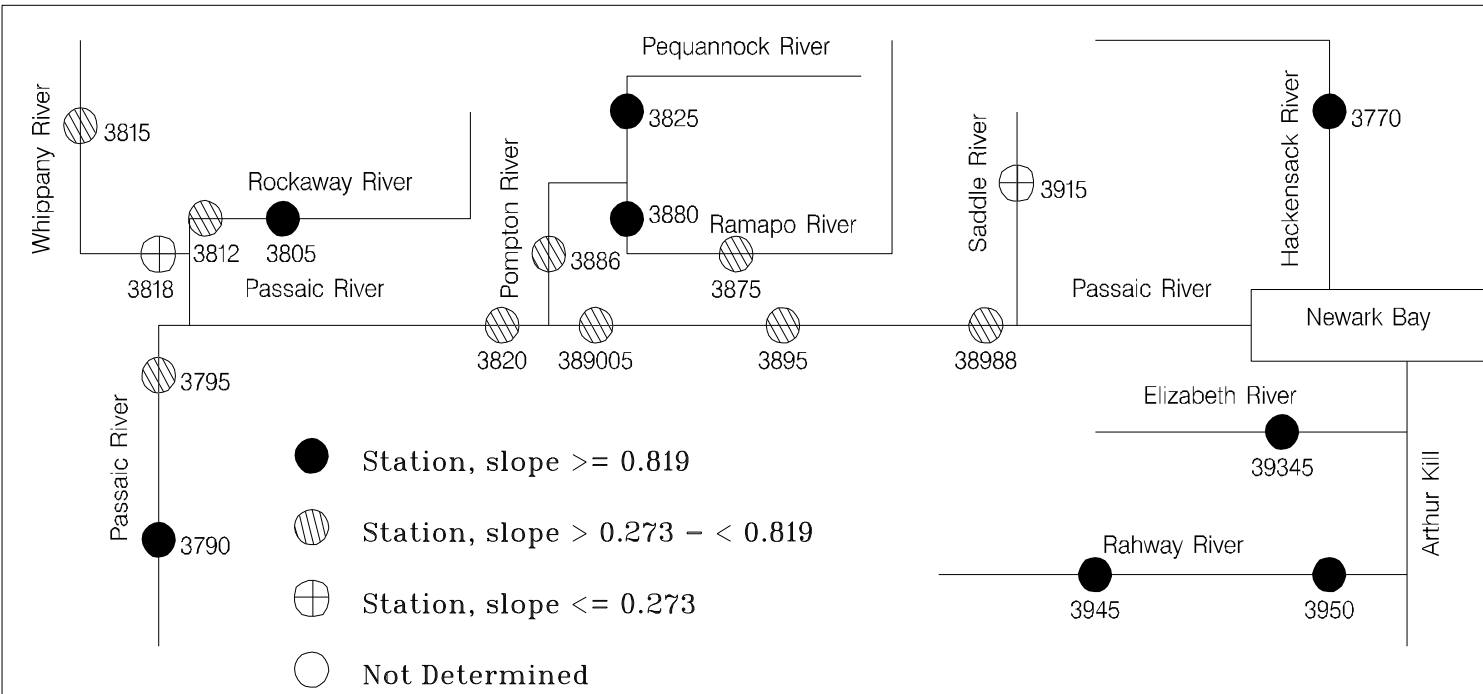

Figure 21. Trends in total nitrite concentrations during (A) high- and (B) low-flow conditions, and $(C)$ relative slope of total nitrite load to streamflow at surface-waterquality stations in the Hackensack, Passaic, Elizabeth, and Rahway River Basins, N.J., water years 1976-93. 
(A)

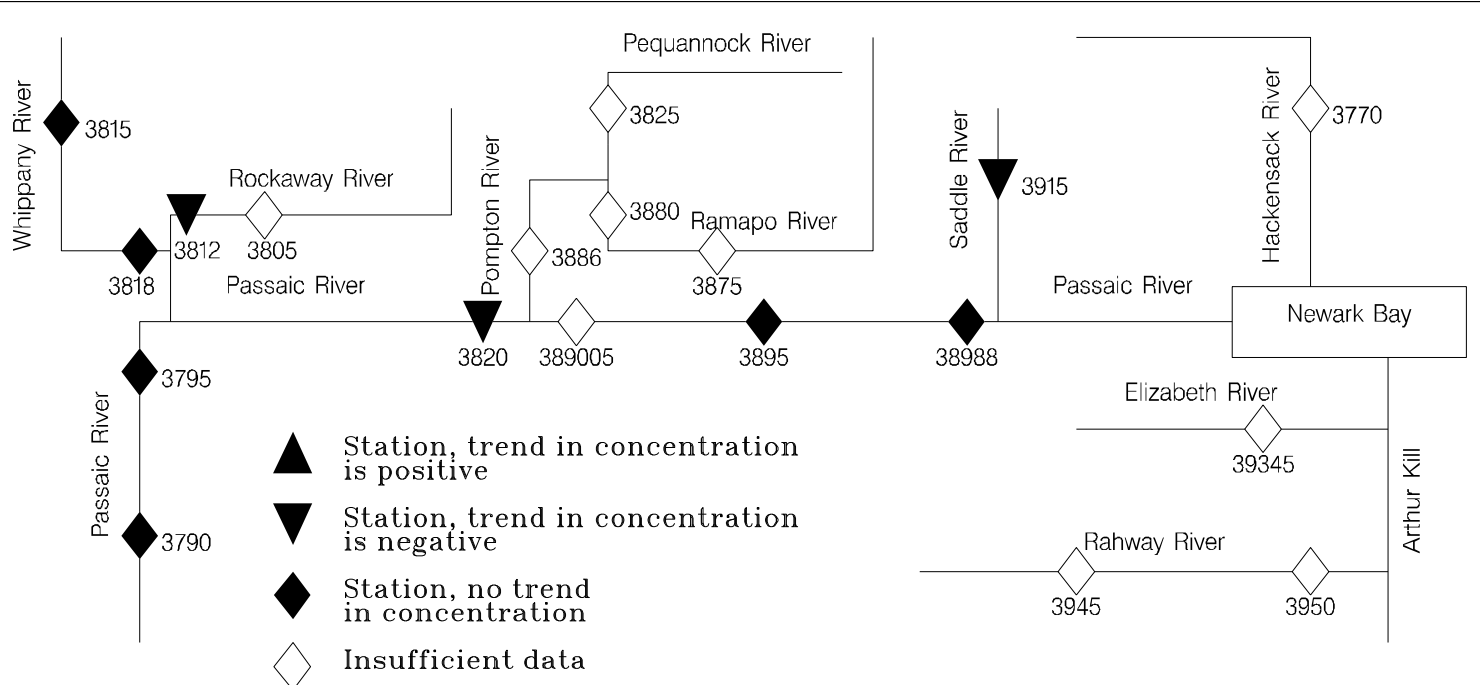

(B)
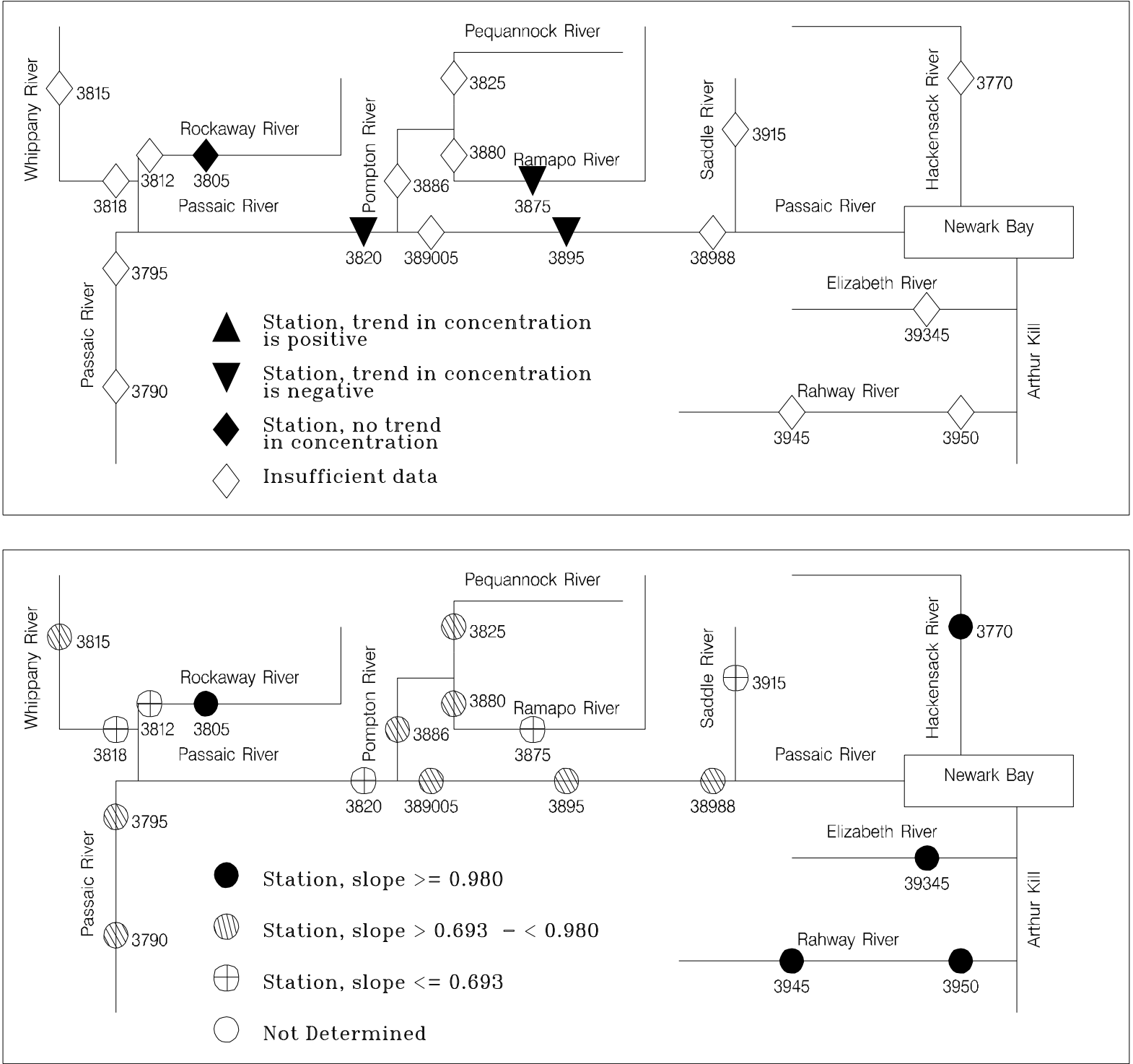

Figure 22. Trends in total ammonia plus organic nitrogen concentrations during $(A)$ highand (B) low-flow conditions, and (C) relative slope of total ammonia plus organic nitrogen load to streamflow at surface-water-quality stations in the Hackensack, Passaic, Elizabeth, and Rahway River Basins, N.J., water years 1976-93. 
nitrogen concentrations during low flows are negative at the downstream station on the upper Passaic River (3820), the upstream station on the Ramapo River (3805), and station 3895 on the lower Passaic River, indicating a decrease in the contribution from point sources and ground water over time at these stations and an improvement in wastewater treatment upstream from these sites (fig. 22b). The concentrations of total ammonia plus organic nitrogen during low flows show no trend at the upstream station on the Rockaway River (3805).

\section{$\underline{\text { Relation of load to streamflow }}$}

The range categories of regression slopes of total ammonia plus total organic nitrogen load to streamflow are depicted in figure 22c. The slopes range from 0.550 at station 3818 on the Whippany River (table 12a) to 1.123 at station 39345 on the Elizabeth River (table 21a). The slopes are in the high range at the one station on the Hackensack River (3770), the upstream station on the Rockaway River (3805), the one station on the Elizabeth River (39345), and both stations on the Rahway River (3945 and 3950). At these sites, the contributions to instream loads from storm runoff are larger and less influenced by point sources and ground water than at other sites in the study area. The slopes are in the low range at the downstream stations on the Rockaway (3812), Whippany (3818), and upper Passaic (3820) Rivers, the upstream station on the Ramapo River (3875), and the one station on the Saddle River (3915). At these sites, the contributions to instream loads from point sources and ground water are larger and less influenced by storm runoff than at other sites in the study area. Slopes at stations on the Rockaway and Whippany Rivers decrease in the downstream direction, indicating an decrease in the contributions from storm runoff along the rivers, whereas slopes at stations on the Ramapo River increase slightly in the downstream direction, indicating an increase in the contributions from storm runoff along the rivers.

\section{Total Ammonia}

Ammonia is produced largely by deamination of organic nitrogen-containing compounds and by hydrolysis of urea. Ammonia can enter surface water by wet deposition with industrial, municipal, and agricultural wastewater and runoff, especially from areas treated with ammonia fertilizers. At some water-treatment plants, ammonia is added to react with chlorine to form a combined chlorine residual. Contributions of ammonia to surface water from ground water are usually small because ammonia can adsorb to soil particles and clays and does not leach from soils (Hem, 1985).

The toxicity of ammonia to fish is dependent on its speciation. Un-ionized ammonia is considered to be the toxic form to aquatic organisms (Rand and Petrocelli, 1985). The relative concentrations of ionized $\left(\mathrm{NH}_{4}^{+}\right)$and un-ionized $\left(\mathrm{NH}_{3}\right)$ ammonia are a function of the $\mathrm{pH}$, temperature, and ionic strength of the aqueous solution. When the $\mathrm{pH}$, temperature, and totalammonia concentration are measured in a solution, the relative concentrations of $\mathrm{NH}_{3}$ and $\mathrm{NH}_{4}{ }^{+}$ can be calculated. Decreased dissolved-oxygen concentrations can cause an increase in ammonia toxicity. 


\section{$\underline{\text { Relation of trends in concentration to flow conditions }}$}

The trend in total-ammonia concentrations during high flows is negative at the downstream station on the upper Passaic River (3820), indicating a decrease in the contribution from storm runoff over time at this station (fig. 23a). The total-ammonia concentrations during high flows show no trends at the two upstream stations on the upper Passaic River (3790 and 3795), the downstream station on the Rockaway River (3812), both stations on the Whippany River (3815 and 3818), and the downstream station on the lower Passaic River (38988). The trends in total ammonia concentrations during low flows are negative at the downstream station on the upper Passaic River (3820) and the upstream station on the Ramapo River (3875), indicating a decrease in the contribution from point sources and ground water over time at these stations (fig. 23b). Total ammonia concentrations during low flows show no trends at the upstream stations on Rockaway River (3805) and the one station on the Saddle River (3915).

\section{Relation of load to streamflow}

The range categories of regression slopes of total ammonia load are depicted in figure $23 \mathrm{c}$. The slopes range from 0.251 at station 3915 on the Saddle River (table 20a) to 1.206 at station 3880 on the Ramapo River (table 15a). The slopes are in the high range at the upstream stations on the Rockaway (3805) and Whippany (3815) Rivers, the downstream stations on the Ramapo (3880) and lower Passaic (38988) Rivers, the one station on the Elizabeth River (39345), and the downstream station on the Rahway River (3950). At these sites, the contributions to instream total ammonia load from storm runoff are larger and less influenced by point sources and ground water than at other sites in the study area. The slopes are in the low range at the downstream stations on the Whippany (3818) and upper Passaic (3820) Rivers and the one station on the Saddle River (3915), indicating that the contributions to instream total ammonia loads from point sources and ground water are larger and less influenced by storm runoff than at other sites in the study area. Slopes at stations on the Whippany and Rockaway Rivers decrease in the downstream direction, indicating a decrease in the contributions from storm runoff along the rivers. Slopes at stations on the Ramapo, lower Passaic, and Rahway Rivers increase in the downstream direction, indicating an increase in the contributions from storm runoff along the rivers.

\section{Total Boron}

Boron is a minor constituent in most surface water. Small amounts of boron are essential for plant growth. Boron minerals are present in some igneous rocks; water in volcanic areas and thermal springs may contain considerable concentrations of boron (Hem, 1985). Boron from the cleaning agent, sodium tetraborate (borax), can be present in surface water as a result of the release of treated sewage and industrial-use water.

\section{$\underline{\text { Relation of trends in concentration to flow conditions }}$}

Insufficient data are available to determine trends in boron concentrations during high and low flows at all stations in the study area (figs. 24a and b). 
(A)

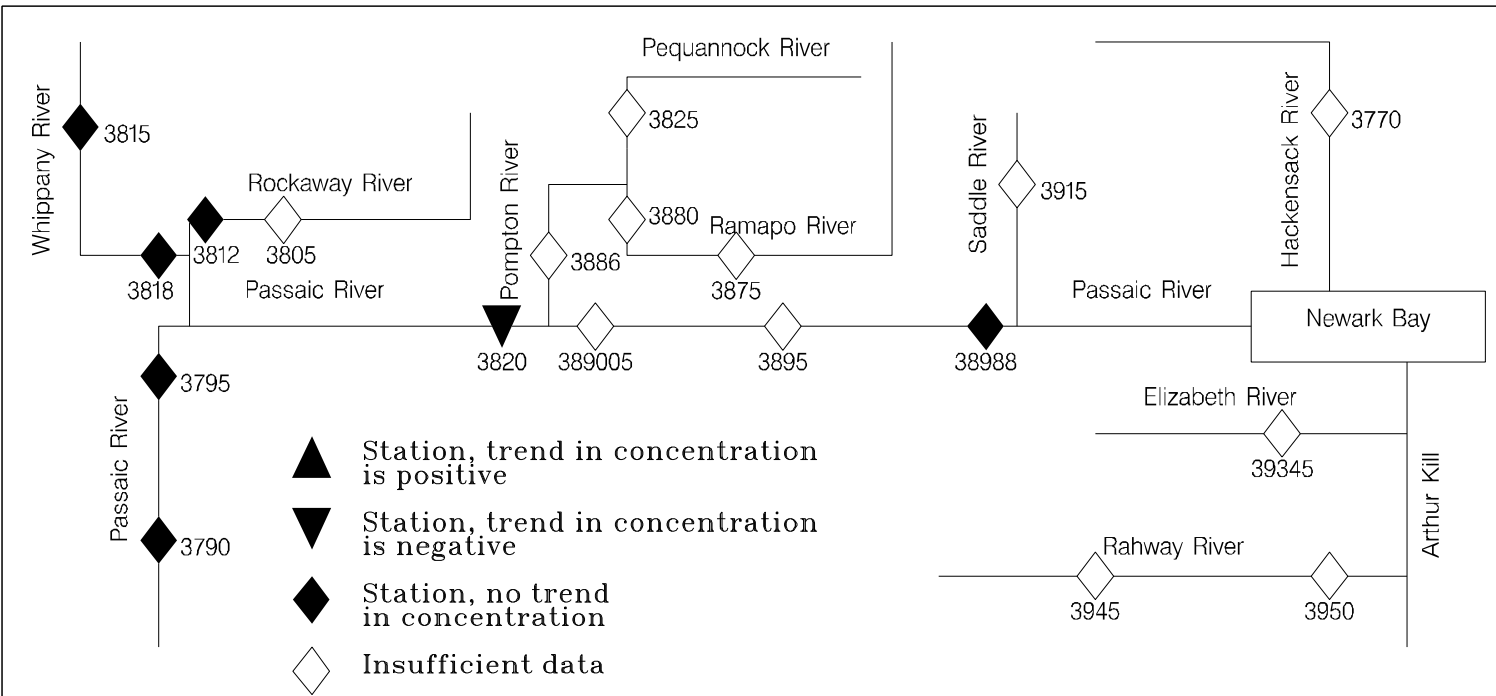

(B)

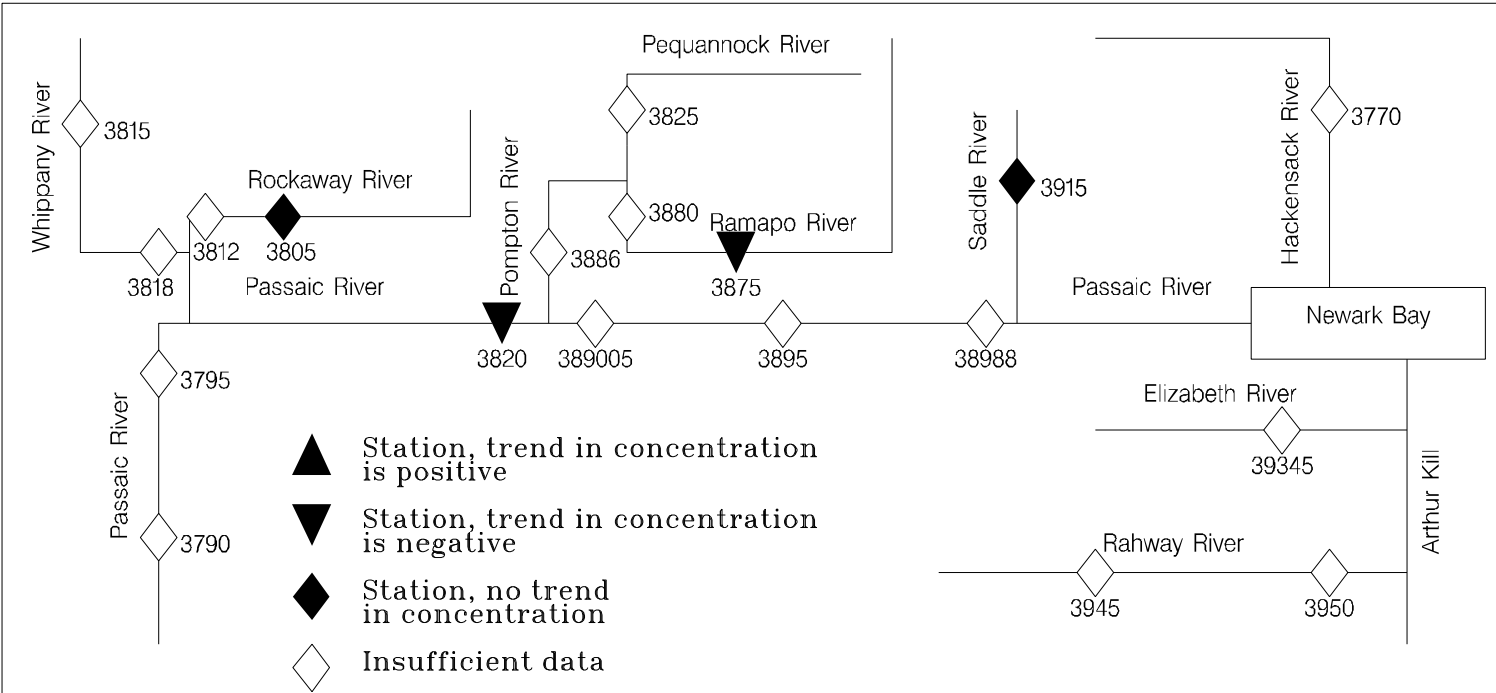

(C)

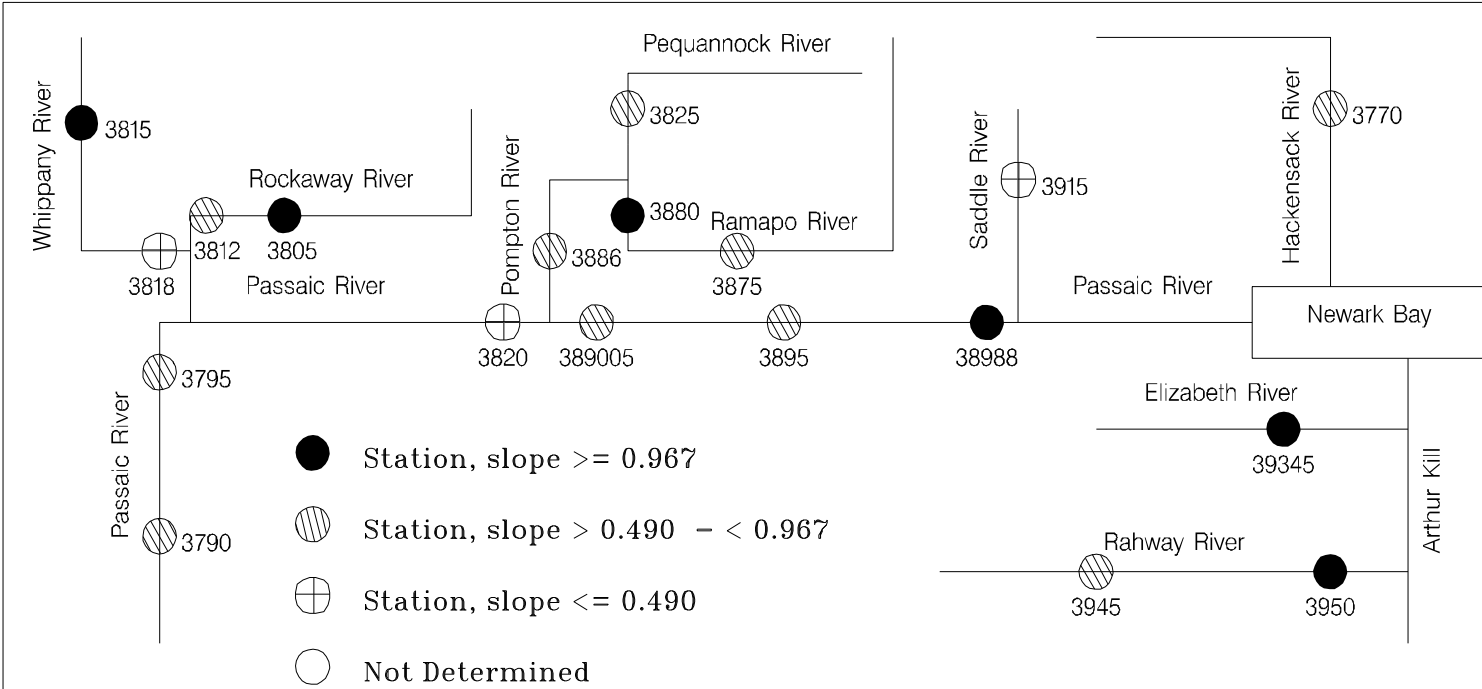

Figure 23. Trends in total ammonia concentrations during (A) high- and (B) low-flow conditions, and $(C)$ relative slope of total ammonia load to streamflow at surface-waterquality stations in the Hackensack, Passaic, Elizabeth, and Rahway River Basins, N.J., water years 1976-93. 
(A)

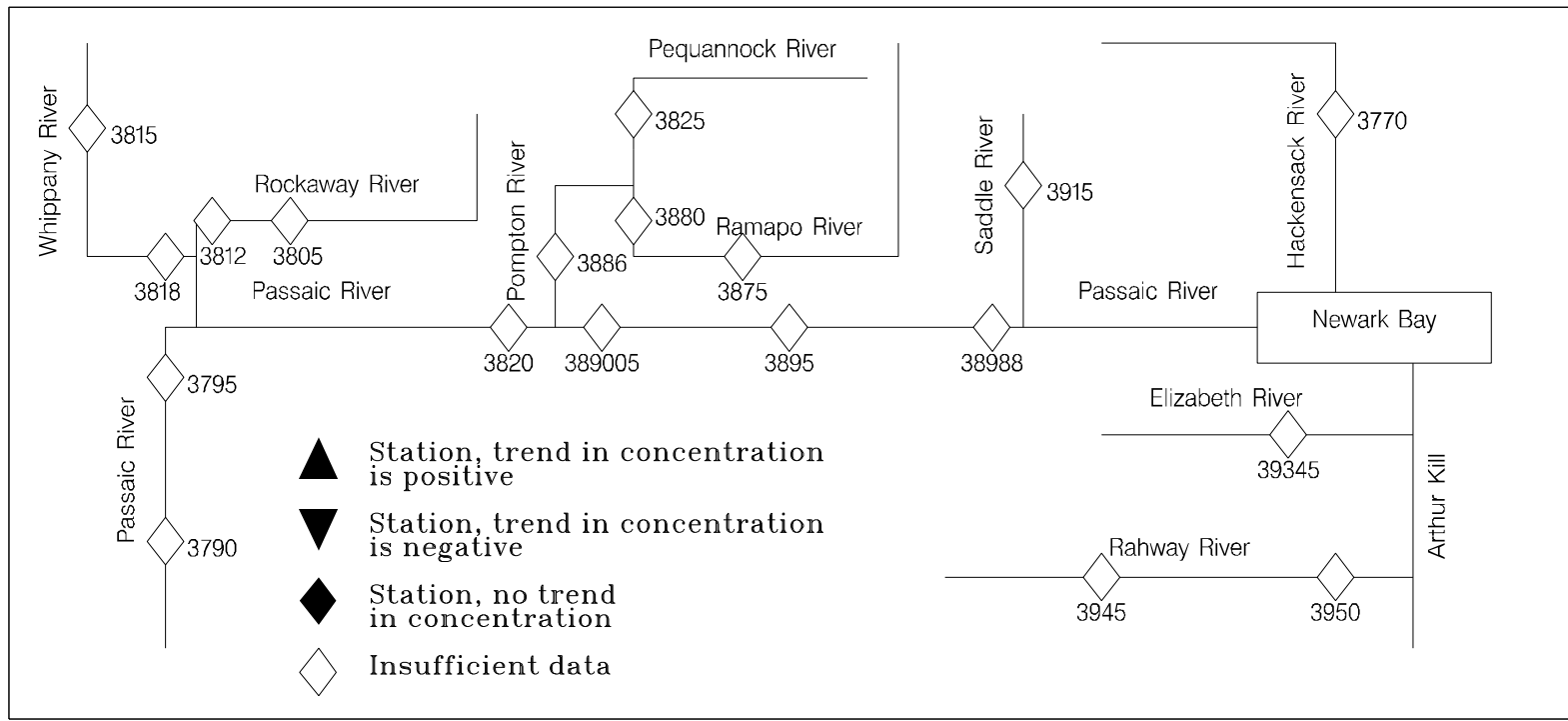

(B)

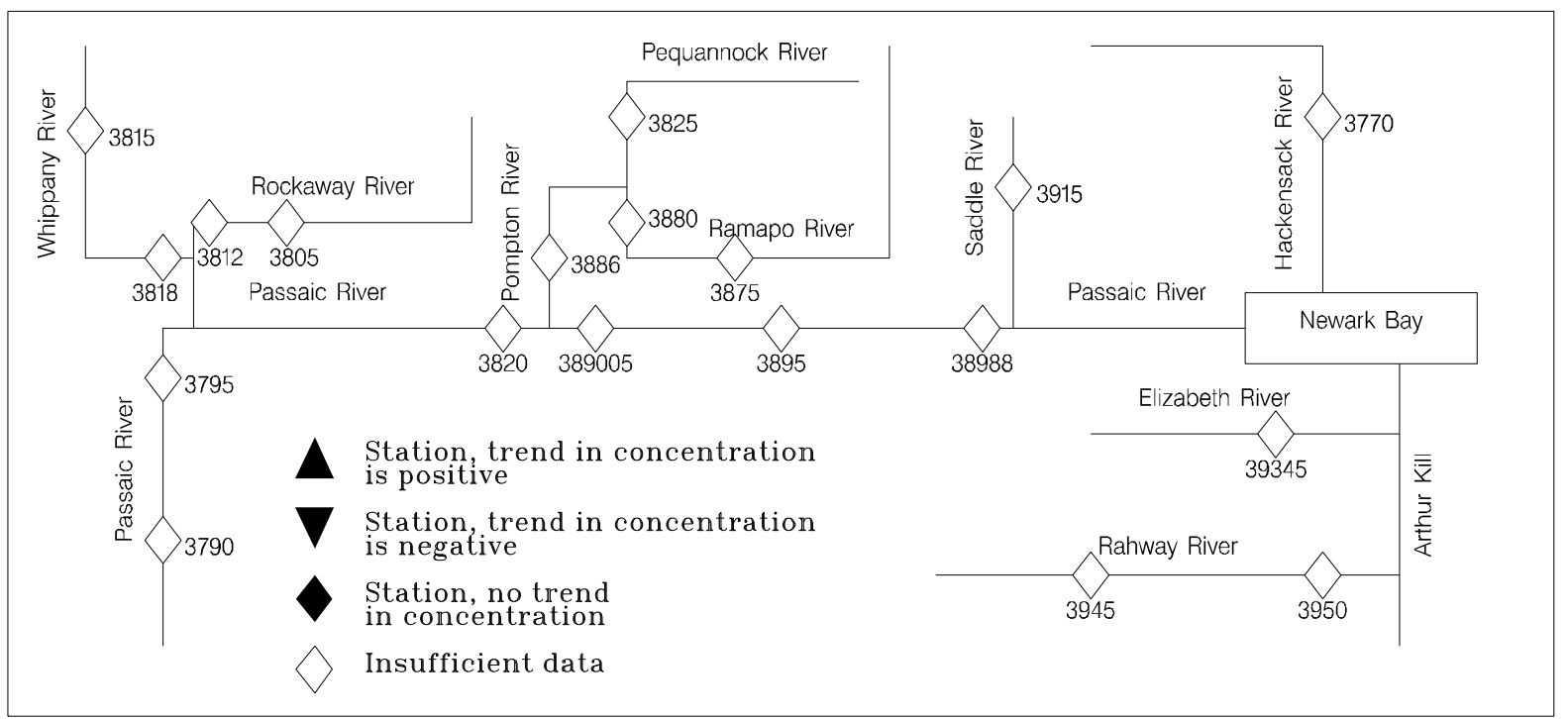

(C)

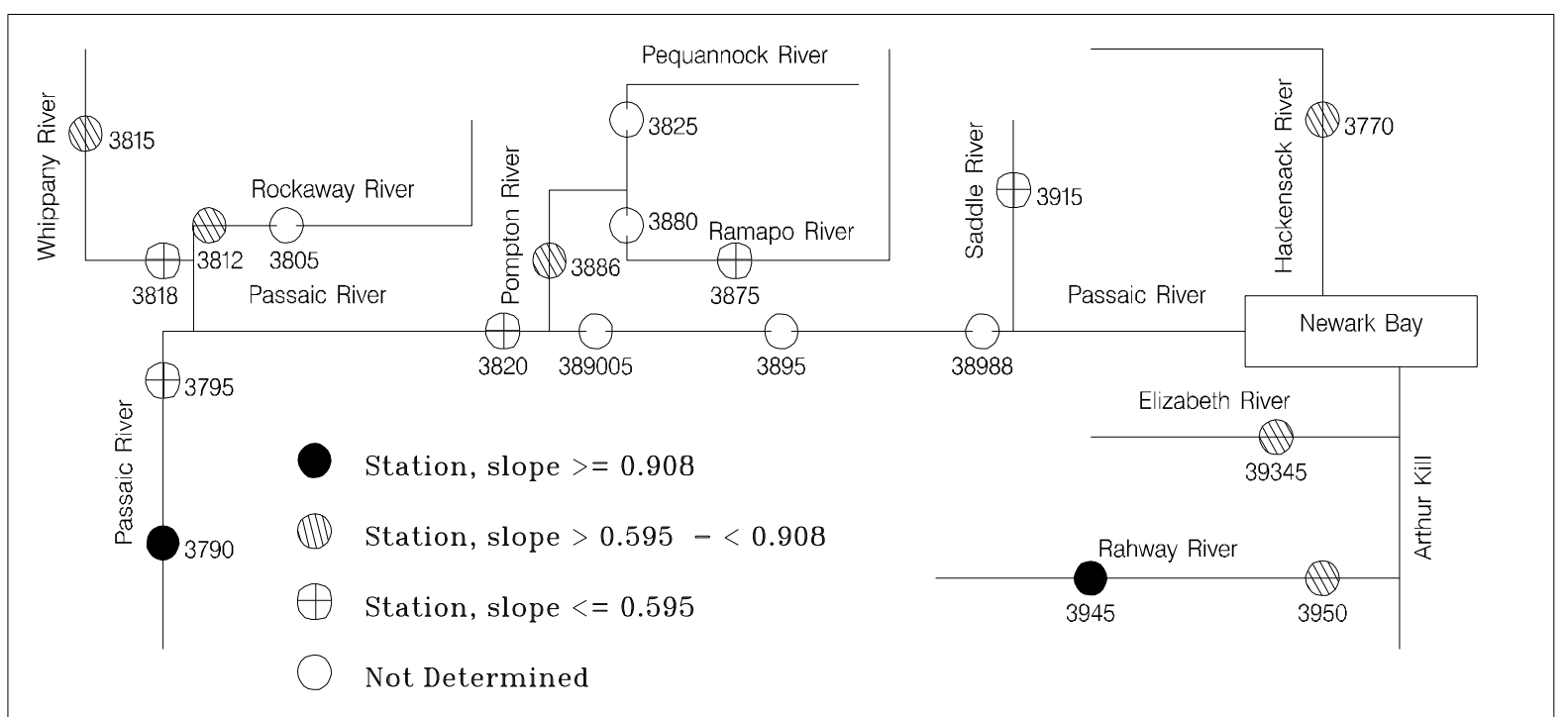

Figure 24. Trends in total boron concentrations during $(A)$ high- and $(B)$ low-flow conditions, and $(C)$ relative slope of total boron load to streamflow at surface-waterquality stations in the Hackensack, Passaic, Elizabeth, and Rahway River Basins, N.J., water years 1976-93. 


\section{$\underline{\text { Relation of load to streamflow }}$}

The range categories of regression slopes of total boron to streamflow are depicted in figure 24c. Sufficient data are not available to determine slopes at six of the stations. The slopes range from 0.439 at station 3875 on the Ramapo River (table 14a) to 1.064 at station 3945 on the Rahway River (table 22a). The slopes are in the high range at the upstream stations on the upper Passaic (3790) and Rahway (3945) Rivers, indicating contributions to instream boron load from storm runoff are larger and less influenced by point sources and ground water than at other sites in the study area. The slopes are in the low range at the downstream stations on the upper Passaic (3795 and 3820) and Whippany (3818) Rivers, the upstream station on the Ramapo River (3875), and the one station on the Saddle River (3915), indicating that the contributions to instream total boron loads from point sources and ground water are larger and less influenced by storm runoff than at other sites in the study area.

\section{Total Lead}

Lead is occasionally present in surface water in trace amounts, which can be toxic to aquatic organisms. Lead is widely dispersed in sedimentary rocks; however, its mobility is low (Hem, 1985). The many uses of lead have dispersed the element throughout the environment. Dry fallout and rain-out of particulate lead is probably a factor of major importance in the circulation of the element. Concentrations of lead in rain and snow are greater in areas subject to substantial air pollution than in more remote areas. Storm runoff is a potential source of lead in surface water.

\section{$\underline{\text { Relation of trends in concentration to flow conditions }}$}

Insufficient data are available to determine trends in lead concentrations during high and low flows at all stations in the study area (figs. $25 \mathrm{a}$ and b).

\section{$\underline{\text { Relation of load to streamflow }}$}

The range categories of regression slopes of total lead to streamflow are depicted in figure 25c. Sufficient data are not available to determine slopes at two of the stations. The slopes range from 0.861 at station 3770 on the Hackensack River to (table 5) 1.872 at station 39345 on the Elizabeth River (table 21). The slopes are in the high range at the upstream stations on the Rockaway (3805) and Whippany (3815) Rivers and the one station on each of the Saddle (3915) and Elizabeth (39345) Rivers, indicating contributions to instream total lead load from storm runoff are larger and less influenced by point sources and ground water than at other sites in the study area. The slopes are in the low range at the downstream station on the upper Passaic River (3820), the upstream station on the Ramapo River (3875), the one station on the Pompton River (3886), and the downstream station on the lower Passaic River (38988). At these stations, the contributions to instream total-lead loads from point sources and ground water probably are relatively insignificant because the load-to-streamflow slopes are large (greater than 0.8). Storm runoff most likely is the dominant contributor of total lead in the study area because the load-tostreamflow slopes at all stations are large. The minimum slope value for total lead is larger than the minimum slope value for all other constituents. 
(A)

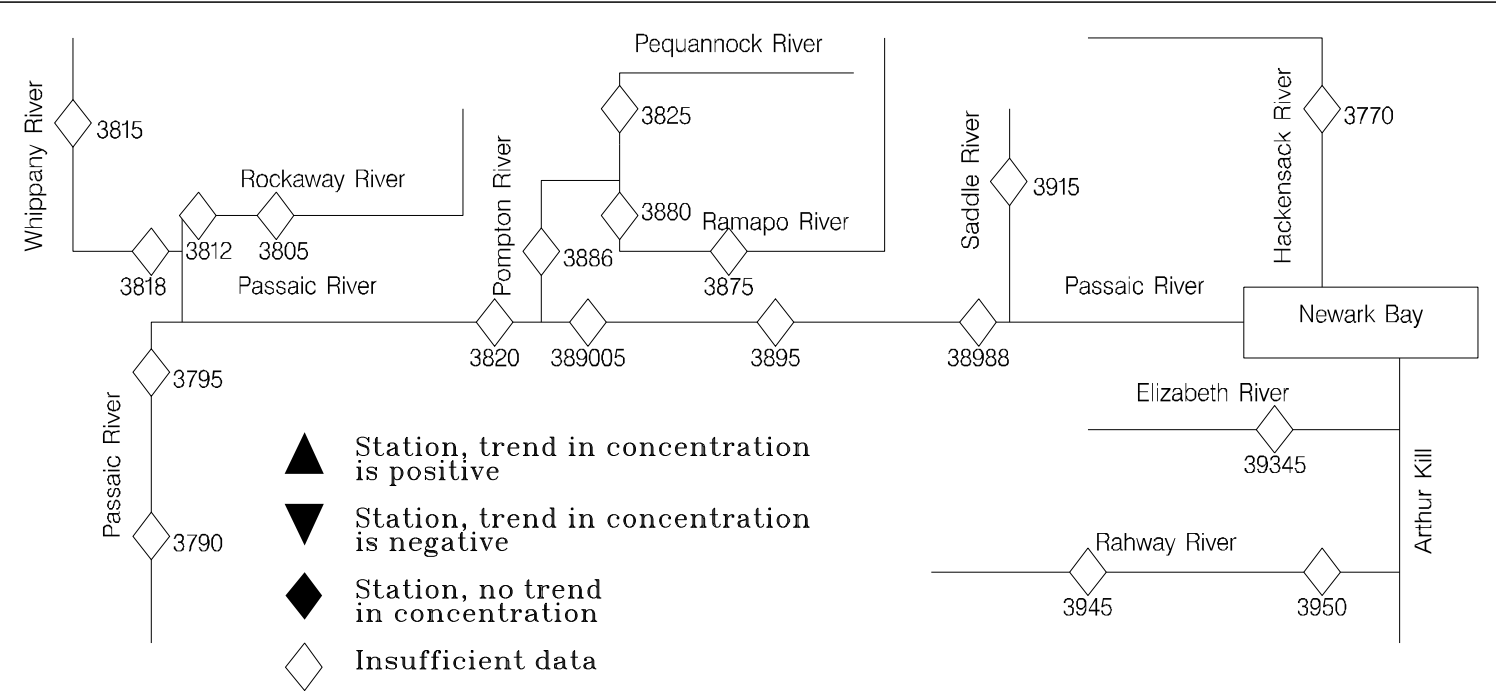

(B)

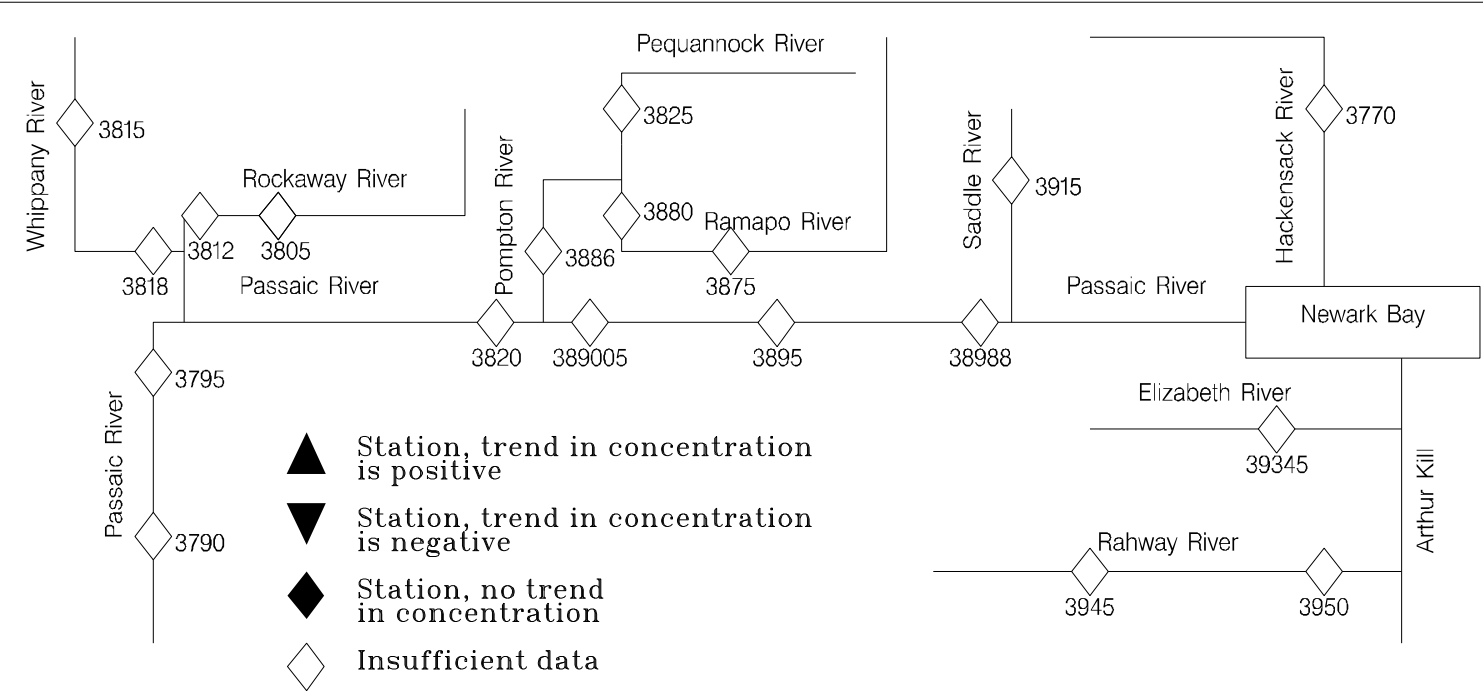

(C)

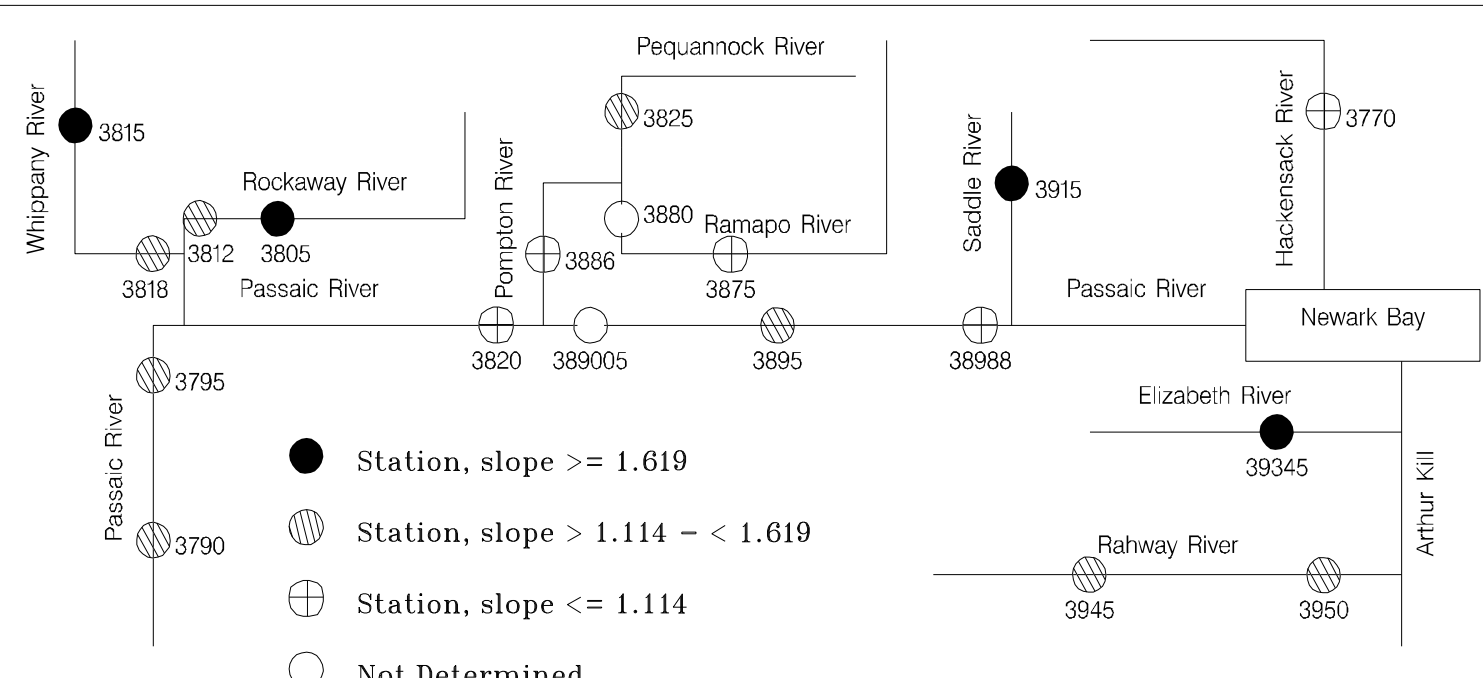

Not Determined

Figure 25. Trends in total lead concentrations during (A) high- and (B) low-flow conditions, and $(C)$ relative slope of total lead load to streamflow at surface-waterquality stations in the Hackensack, Passaic, Elizabeth, and Rahway River Basins, N.J., water years 1976-93. 


\section{Fecal Coliform Bacteria}

Fecal coliform bacteria are present in the intestine and feces of warm-blooded animals. The presence of high numbers of fecal coliform bacteria in surface water can indicate the recent release of untreated wastewater or the presence of animal feces, or both. These organisms also can indicate the presence of pathogens that are harmful to humans. High numbers of fecal coliform bacteria can render surface water unfit for some uses, such as swimming and fishing. Fecal coliform bacteria are often used as indicators of the sanitary quality of the water (Eaton and others, 1995). For laboratory purposes, fecal coliform bacteria are defined as all organisms that produce blue colonies within 24 hours when incubated at $44.5^{\circ} \mathrm{C} \pm 0.2{ }^{\circ} \mathrm{C}$ on M-FC medium (nutrient medium for bacterial growth) (Bauersfeld and others, 1994).

\section{Relation of trends in concentration to flow conditions}

The trend in fecal coliform bacteria concentrations during high flows is negative at the downstream station on the Whippany River (3818), indicating a decrease in the contribution from storm runoff over time at this station (fig. 26a). The fecal coliform bacteria concentrations during high flows show no trends at all stations on the upper Passaic River (3790, 3795, and 3820), the upstream stations on the Rockaway (3812) and Whippany (3815) Rivers, and the one station on the Saddle River (3915). The trend in fecal coliform bacteria concentrations during low flows is

positive at the upstream station on the Ramapo River (3875), indicating an increase in the contribution from point sources and ground water over time at this station (fig. 26b), and is insignificant at the upstream station on the Rockaway River (3805) and the one station on the Saddle River (3915).

\section{COMPARISON OF RESULTS}

Positive trends in constituent concentrations over time during low flows indicate increasing constant-rate source contributions at station 3820 on the upper Passaic River for HARD and total NO32; at station 3875 on the Ramapo River for BACT; at stations 3820 and 3875 for DO; at stations 3820 and 3895 on the Passaic River for FDO; and at stations 3820, 3895, and 3915 for CL (table 24). Negative trends during low flows indicate decreasing constant-rate source contributions at stations 3820,3875 , and 3895 for TAON, and at stations 3820 and 3875 for NH4 (table 24).

Positive trends during high flows indicate increasing intermittent source contributions at station 3812 for DS; station 3818 for DO; stations 3790 and 3915 for HARD; stations 3812 and 3915 for NA; stations 3795 and 3812 for FDO; and stations 3812, 3818, and 3915 for CL (table 25). Negative trends during high flows indicate decreasing intermittent source contributions at station 3812 for TOC; station 3895 for SS; station 3820 for NH4; station 3818 for BACT; and stations 3812,3820 , and 3915 for TAON (table 25). 
(A)

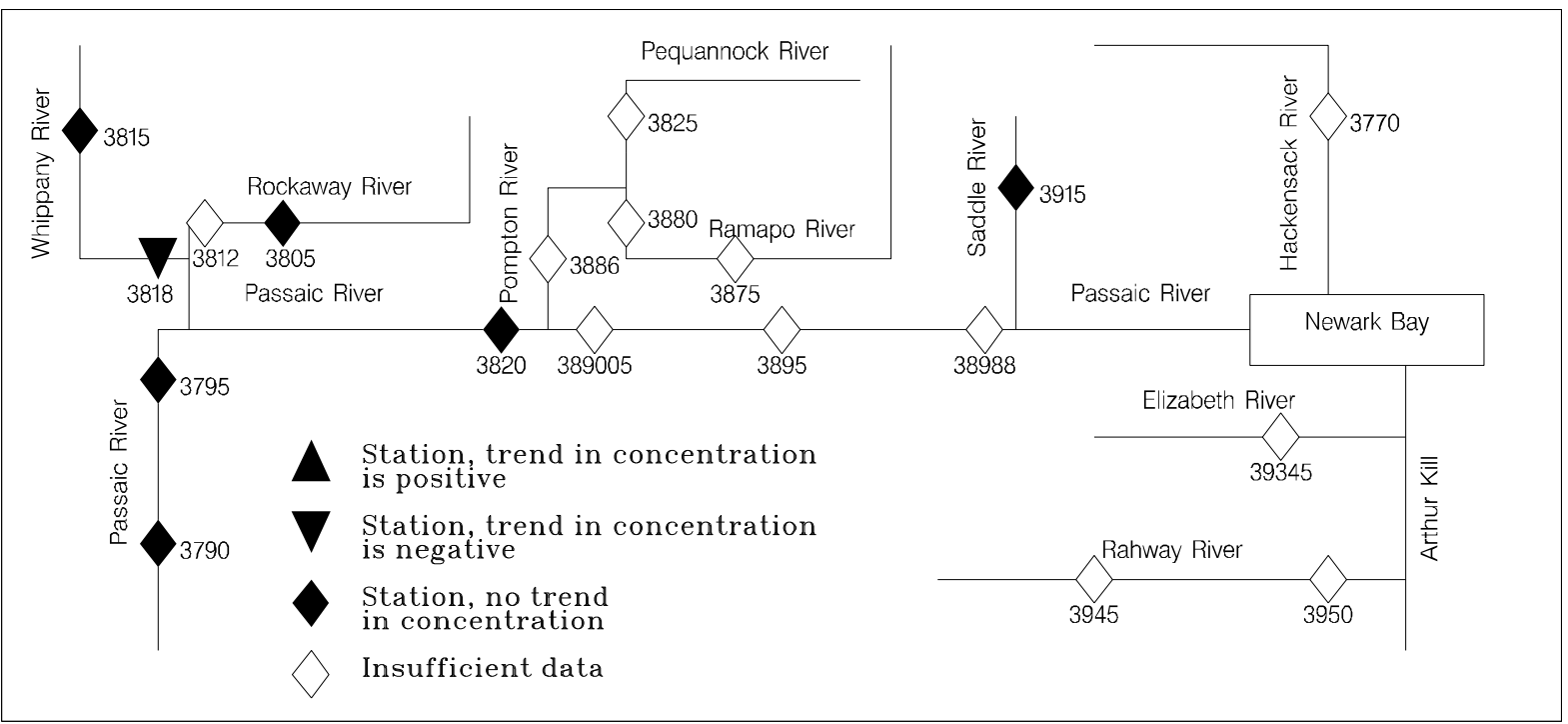

(B)

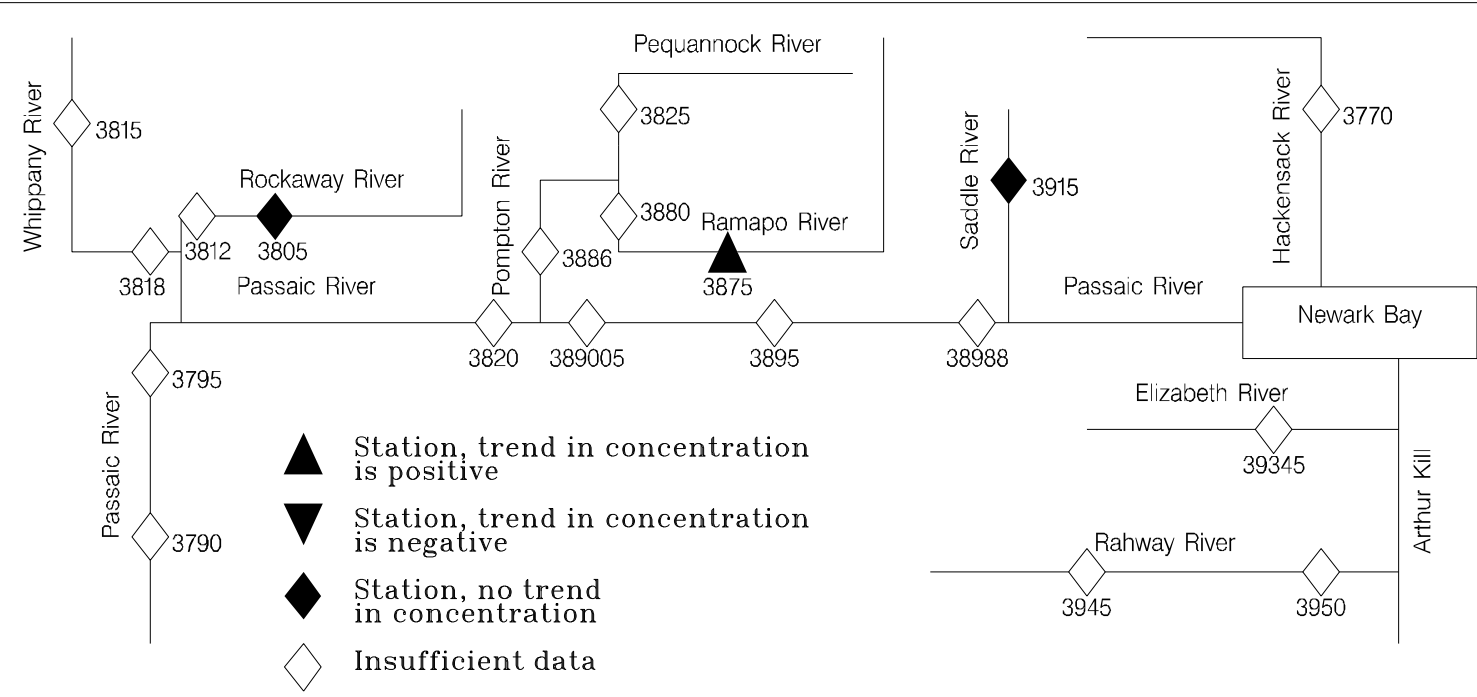

Figure 26. Trends in fecal coliform bacteria concentrations during (A) high- and (B) lowflow conditions, at surface-water-quality stations in the Hackensack, Passaic, Elizabeth, and Rahway River Basins, N.J., water years 1976-93. 
Table 24. Concentration trends during low flow at surface-water-quality monitoring in the Hackensack, Elizabeth, Rahway, and Passaic River Basins, water years 1976-1992

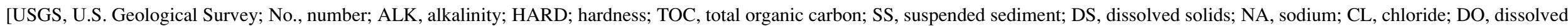

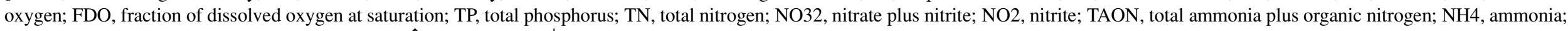

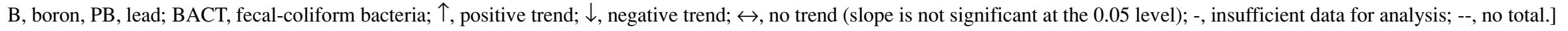

\begin{tabular}{|c|c|c|c|c|c|c|c|c|c|c|c|c|c|c|c|c|c|c|c|c|c|c|}
\hline River basin & $\begin{array}{l}\text { USGS station } \\
\text { number }\end{array}$ & ALK & HARD & TOC & SS & DS & NA & $\mathrm{CL}$ & DO & FDO & $\mathrm{TP}$ & $\mathrm{TN}$ & NO32 & $\mathrm{NO} 2$ & TAON & NH4 & B & PB & BACT & $\begin{array}{l}\text { No. of } \\
\text { constitu- } \\
\text { ents with a } \\
\text { positive } \\
\text { trend }\end{array}$ & $\begin{array}{c}\text { No. of } \\
\text { constitu- } \\
\text { ents with a } \\
\text { negative } \\
\text { trend }\end{array}$ & $\begin{array}{l}\text { No. of } \\
\text { constitu- } \\
\text { ents with } \\
\text { no trend }\end{array}$ \\
\hline Hackensack & 01377000 & - & - & - & - & - & - & - & - & - & - & - & - & - & - & - & - & - & - & 0 & 0 & 0 \\
\hline \multirow[t]{2}{*}{ Upper Passaic } & 01379000 & - & - & - & - & - & - & - & - & - & - & - & - & - & - & - & - & - & - & 0 & 0 & 0 \\
\hline & 01379500 & - & - & - & - & - & - & - & - & - & - & - & - & - & - & - & - & - & - & 0 & 0 & 0 \\
\hline \multirow[t]{2}{*}{ Rockaway } & 01380500 & - & - & - & - & - & - & - & $\leftrightarrow$ & $\leftrightarrow$ & - & $\leftrightarrow$ & $\leftrightarrow$ & $\leftrightarrow$ & $\leftrightarrow$ & $\leftrightarrow$ & - & - & $\leftrightarrow$ & 0 & 0 & 8 \\
\hline & 01381200 & - & - & - & - & - & - & - & - & - & - & - & - & - & - & - & - & - & - & 0 & 0 & 0 \\
\hline \multirow{2}{*}{ Whippany } & 01381500 & - & - & - & - & - & - & - & - & - & - & - & - & - & - & - & - & - & - & 0 & 0 & 0 \\
\hline & 01381800 & - & - & - & - & - & - & - & - & - & - & - & - & - & - & - & - & - & - & 0 & 0 & 0 \\
\hline Upper Passaic & 01382000 & - & $\uparrow$ & $\leftrightarrow$ & - & $\leftrightarrow$ & $\leftrightarrow$ & $\uparrow$ & $\uparrow$ & $\uparrow$ & - & $\leftrightarrow$ & $\uparrow$ & - & $\downarrow$ & $\downarrow$ & - & - & - & 5 & 2 & 4 \\
\hline Pequannock & 01382500 & - & - & - & - & - & - & - & - & - & - & - & - & - & - & - & - & - & - & 0 & 0 & 0 \\
\hline \multirow[t]{2}{*}{ Ramapo } & 01387500 & - & $\leftrightarrow$ & $\leftrightarrow$ & - & $\leftrightarrow$ & $\leftrightarrow$ & $\leftrightarrow$ & $\uparrow$ & $\leftrightarrow$ & - & $\leftrightarrow$ & $\leftrightarrow$ & - & $\downarrow$ & $\downarrow$ & - & - & $\uparrow$ & 1 & 2 & 8 \\
\hline & 01388000 & - & - & - & - & - & - & - & - & - & - & - & - & - & - & - & - & - & - & 0 & 0 & 0 \\
\hline Pompton & 01388600 & - & - & - & - & - & - & - & - & - & - & - & - & - & - & - & - & - & - & 0 & 0 & 0 \\
\hline \multirow[t]{3}{*}{ Lower Passaic } & 01389005 & - & - & - & - & - & - & - & - & - & - & - & - & - & - & - & - & - & - & 0 & 0 & 0 \\
\hline & 01389500 & - & $\leftrightarrow$ & - & - & $\leftrightarrow$ & $\leftrightarrow$ & $\uparrow$ & $\leftrightarrow$ & $\uparrow$ & - & $\leftrightarrow$ & - & - & $\downarrow$ & - & - & - & - & 2 & 1 & 5 \\
\hline & 01389880 & - & - & - & - & - & - & - & - & - & - & - & - & - & - & - & - & - & - & 0 & 0 & 0 \\
\hline Saddle & 01391500 & - & $\leftrightarrow$ & $\leftrightarrow$ & - & $\leftrightarrow$ & $\leftrightarrow$ & $\uparrow$ & $\leftrightarrow$ & $\leftrightarrow$ & $\leftrightarrow$ & - & $\leftrightarrow$ & - & - & $\leftrightarrow$ & - & - & $\leftrightarrow$ & 1 & 0 & 10 \\
\hline Elizabeth & 01393450 & - & - & - & - & - & - & - & - & - & - & - & - & - & - & - & - & - & - & 0 & 0 & 0 \\
\hline \multirow[t]{2}{*}{ Rahway } & 01394500 & - & - & - & - & - & - & - & - & - & - & - & - & - & - & - & - & - & - & 0 & 0 & 0 \\
\hline & 01395000 & - & - & - & - & - & - & - & - & - & - & - & - & - & - & - & - & - & - & 0 & 0 & 0 \\
\hline \multicolumn{2}{|c|}{ No. of stations with a positive trend } & 0 & 1 & 0 & 0 & 0 & 0 & 3 & 2 & 2 & 0 & 0 & 1 & 0 & 0 & 0 & 0 & 0 & 0 & -- & -- & -- \\
\hline \multicolumn{2}{|c|}{ No. of stations with a negative trend } & 0 & 0 & 0 & 0 & 0 & 0 & 0 & 0 & 0 & 0 & 0 & 0 & 0 & 3 & 2 & 0 & 0 & 0 & -- & -- & -- \\
\hline \multicolumn{2}{|c|}{ No. of stations with no trend } & 0 & 3 & 3 & 0 & 4 & 4 & 1 & 3 & 3 & 1 & 4 & 3 & 1 & 1 & 2 & 0 & 0 & 2 & -- & -- & -- \\
\hline
\end{tabular}


Table 25. Concentration trends during high flow at surface-water-quality stations in the Hackensack, Elizabeth, Rahway, and Passaic River Basins, water years 1976-1992

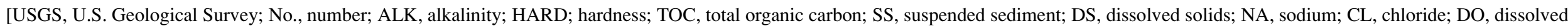

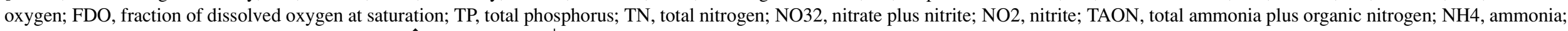

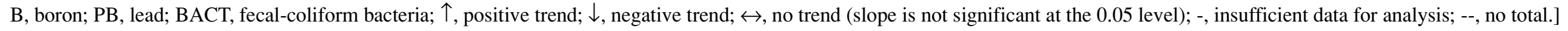

\begin{tabular}{|c|c|c|c|c|c|c|c|c|c|c|c|c|c|c|c|c|c|c|c|c|c|c|}
\hline River basin & $\begin{array}{l}\text { USGS station } \\
\text { number }\end{array}$ & ALK & HARD & TOC & SS & DS & NA & $\mathrm{CL}$ & DO & FDO & $\mathrm{TP}$ & $\mathrm{TN}$ & NO32 & $\mathrm{NO} 2$ & TAON & NH4 & B & PB & BACT & $\begin{array}{l}\text { No. of } \\
\text { constitu- } \\
\text { ents with a } \\
\text { positive } \\
\text { trend }\end{array}$ & $\begin{array}{l}\text { No. of } \\
\text { constitu- } \\
\text { ents with a } \\
\text { negative } \\
\text { trend }\end{array}$ & $\begin{array}{l}\text { No. of } \\
\text { constitu- } \\
\text { ents with } \\
\text { no trend }\end{array}$ \\
\hline Hackensack & 01377000 & - & - & - & - & - & - & - & - & - & - & - & - & - & - & - & - & - & - & 0 & 0 & 0 \\
\hline \multirow[t]{2}{*}{ Upper Passaic } & 01379000 & - & $\uparrow$ & $\leftrightarrow$ & - & $\leftrightarrow$ & $\leftrightarrow$ & $\leftrightarrow$ & $\leftrightarrow$ & $\leftrightarrow$ & - & $\leftrightarrow$ & $\leftrightarrow$ & - & $\leftrightarrow$ & $\leftrightarrow$ & - & - & $\leftrightarrow$ & 1 & 0 & 11 \\
\hline & 01379500 & - & $\leftrightarrow$ & $\leftrightarrow$ & - & $\leftrightarrow$ & $\leftrightarrow$ & $\leftrightarrow$ & $\leftrightarrow$ & $\uparrow$ & $\leftrightarrow$ & $\leftrightarrow$ & $\leftrightarrow$ & - & $\leftrightarrow$ & $\leftrightarrow$ & - & - & $\leftrightarrow$ & 1 & 0 & 12 \\
\hline \multirow[t]{2}{*}{ Rockaway } & 01380500 & - & - & - & - & - & - & - & $\leftrightarrow$ & $\leftrightarrow$ & - & - & - & - & - & - & - & - & $\leftrightarrow$ & 0 & 0 & 3 \\
\hline & 01381200 & - & $\leftrightarrow$ & $\downarrow$ & - & $\uparrow$ & $\uparrow$ & $\uparrow$ & $\leftrightarrow$ & $\uparrow$ & - & - & - & - & $\downarrow$ & $\leftrightarrow$ & - & - & - & 4 & 2 & 3 \\
\hline \multirow[t]{2}{*}{ Whippany } & 01381500 & - & $\leftrightarrow$ & $\leftrightarrow$ & - & $\leftrightarrow$ & $\leftrightarrow$ & $\leftrightarrow$ & $\leftrightarrow$ & $\leftrightarrow$ & - & $\leftrightarrow$ & $\leftrightarrow$ & - & $\leftrightarrow$ & $\leftrightarrow$ & - & - & $\leftrightarrow$ & 0 & 0 & 12 \\
\hline & 01381800 & - & $\leftrightarrow$ & $\leftrightarrow$ & - & $\leftrightarrow$ & $\leftrightarrow$ & $\uparrow$ & $\uparrow$ & $\leftrightarrow$ & - & $\leftrightarrow$ & $\leftrightarrow$ & - & $\leftrightarrow$ & $\leftrightarrow$ & - & - & $\downarrow$ & 2 & 1 & 9 \\
\hline Upper Passaic & 01382000 & - & $\leftrightarrow$ & $\leftrightarrow$ & - & $\leftrightarrow$ & $\leftrightarrow$ & $\leftrightarrow$ & $\leftrightarrow$ & $\leftrightarrow$ & - & $\leftrightarrow$ & $\leftrightarrow$ & - & $\downarrow$ & $\downarrow$ & - & - & $\leftrightarrow$ & 0 & 2 & 10 \\
\hline Pequannock & 01382500 & - & - & - & - & - & - & - & - & - & - & - & - & - & - & - & - & - & - & 0 & 0 & 0 \\
\hline \multirow[t]{2}{*}{ Ramapo } & 01387500 & - & - & - & - & - & - & - & - & - & - & - & - & - & - & - & - & - & - & 0 & 0 & 0 \\
\hline & 01388000 & - & - & - & - & - & - & - & - & - & - & - & - & - & - & - & - & - & - & 0 & 0 & 0 \\
\hline Pompton & 01388600 & - & - & - & - & - & - & - & - & - & - & - & - & - & - & - & - & - & - & 0 & 0 & 0 \\
\hline \multirow[t]{3}{*}{ Lower Passaic } & 01389005 & - & - & - & - & - & - & - & - & - & - & - & - & - & - & - & - & - & - & 0 & 0 & 0 \\
\hline & 01389500 & - & $\leftrightarrow$ & - & $\downarrow$ & $\leftrightarrow$ & $\leftrightarrow$ & $\leftrightarrow$ & $\leftrightarrow$ & $\leftrightarrow$ & - & $\leftrightarrow$ & - & - & $\leftrightarrow$ & - & - & - & - & 0 & 1 & 8 \\
\hline & 01389880 & - & - & - & - & - & - & - & $\leftrightarrow$ & - & - & $\leftrightarrow$ & $\leftrightarrow$ & - & $\leftrightarrow$ & $\leftrightarrow$ & - & - & - & 0 & 0 & 5 \\
\hline Saddle & 01391500 & - & $\uparrow$ & - & - & $\leftrightarrow$ & $\uparrow$ & $\uparrow$ & $\leftrightarrow$ & $\leftrightarrow$ & $\leftrightarrow$ & - & - & - & $\downarrow$ & - & - & - & $\leftrightarrow$ & 3 & 1 & 5 \\
\hline Elizabeth & 01393450 & - & - & - & - & - & - & - & - & - & - & - & - & - & - & - & - & - & - & 0 & 0 & 0 \\
\hline \multirow[t]{2}{*}{ Rahway } & 01394500 & - & - & - & - & - & - & - & - & - & - & - & - & - & - & - & - & - & - & 0 & 0 & 0 \\
\hline & 01395000 & - & - & - & - & - & - & - & - & - & - & - & - & - & - & - & - & - & - & 0 & 0 & 0 \\
\hline \multicolumn{2}{|c|}{ No. of stations with a positive trend } & 0 & 2 & 0 & 0 & 1 & 2 & 3 & 1 & 2 & 0 & 0 & 0 & 0 & 0 & 0 & 0 & 0 & 0 & -- & -- & -- \\
\hline \multicolumn{2}{|c|}{ No. of stations with a negative trend } & 0 & 0 & 1 & 1 & 0 & 0 & 0 & 0 & 0 & 0 & 0 & 0 & 0 & 3 & 1 & 0 & 0 & 1 & -- & -- & -- \\
\hline \multicolumn{2}{|c|}{ No. of stations with no trend } & 0 & 6 & 5 & 0 & 7 & 6 & 5 & 9 & 7 & 2 & 7 & 6 & 0 & 6 & 6 & 0 & 0 & 6 & -- & -- & -- \\
\hline
\end{tabular}


The negative trends for TAON and NH4 at station 3820 on the upper Passaic River during low and high flows could result from an improvement in wastewater treatment. NO32 (the oxidized species of nitrogen) and DO show positive trends during low flows, indicating the improving conditions of surface-water quality.

Insufficient data are available for 8 of the 19 water-quality stations-3770, 3825, 3880, $3886,389005,39345,3945$, and 3950 - to determine trends in concentrations during both high and low flows, indicating a need for additional data collection or a change in the data collection schedule. Only high flow trends are evident for stations 3790 and 3795 on the upper Passaic River, 3812 on the Rockaway River, and 3815 and 3818 on the Whippany River. Only low flow trends are evident for station 3875 on the Ramapo River. Trends tests are conducted only where there is at least one measurement in each period, which consists of not less than four of the six water years in each one-third of the period of study (18 years); therefore, no trend results from a lack of data.

Relations of concentration to streamflow show that concentrations decrease with increasing flows (dilution); therefore, negative slopes predominate. A significant seasonal dependency (a total of 10 more stations per constituent) is evident for TOC, DS, NA, CL, DO, FDO, TP, NO32, NO2, and BACT (table 26). Seasonal dependency is not evident at any station for B or PB. DO shows seasonal dependency at all stations, possibly because of its relation to bioactivity in surface water. NA and CL most likely show seasonal dependency because of road salting; NA and CL also have an effect on the seasonality of DS. NO2 makes up only a small part of the TN concentration, but it is more seasonally dependent than NO32 or TAON.

Slopes of load-to-streamflow relations along a river reach generally remain constant or decrease in a downstream direction, indicating increased relative importance of point sources and ground water. The exception, increasing slopes in the downstream direction or the increased relative importance of storm runoff, occurs for some or all of the nutrient species on the Ramapo, lower Passaic, and Rahway Rivers; for DS, NA, and CL on the lower Passaic River; and for ALK and HARD on the Rahway River.

Overall, for ALK, TOC, and the inorganics, more slopes are in the low range than the high range, indicating an increased relative importance of point sources and ground water (table 27). For the upper Passaic and Elizabeth Rivers, most slopes are in the low range. For the Hackensack and Rahway Rivers, no slopes are in the low range, but a significant number are in the high range, indicating an increased relative importance of nonpoint sources. The load-to-streamflow slopes are larger for suspended sediment than for any other constituent at all stations, indicating the greater importance of storm runoff than point sources and ground water. During high flows, streambed scour adds to the instream load, complicating the analyses of point-source and stormrunoff influences on SS. The load-to-streamflow slopes are also large for TOC and PB, indicating a greater importance of storm runoff than point sources and ground water as a contributor of these water-quality constituents.

In general, for the nutrients more slopes are in the high range than the low range, indicating an increased relative importance of storm runoff (table 28). At station 3805 on the Rockaway River, station 3880 on the Ramapo River, and all stations on the Elizabeth and Rahway 
Table 26. Seasonal dependency at surface-water-quality stations in the Hackensack, Passaic, Elizabeth, and Rahway River Basins, N.J., water years 1976-93

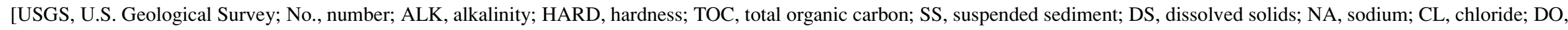
dissolved oxygen; FDO, fraction of dissolved oxygen at saturation; TP, total phosphorus; TN, total nitrogen; NO32, nitrate plus nitrite; NO2, nitrite; TAON, total ammonia plus organic nitrogen; NH4, ammonia; B, boron; PB, lead; BACT, fecal-coliform bacteria; S indicates seasonal dependency(the slope and (or) intercept of growing (April through October) and nongrowing (November through March) season data were different at the 0.05 significance level; -, no seasonal dependency or insufficient data for analysis; --, no total]

\begin{tabular}{|c|c|c|c|c|c|c|c|c|c|c|c|c|c|c|c|c|c|c|c|c|}
\hline River basin & $\begin{array}{l}\text { USGS } \\
\text { station } \\
\text { number }\end{array}$ & ALK & HARD & TOC & SS & DS & NA & $\mathrm{CL}$ & DO & FDO & $\mathrm{TP}$ & $\mathrm{TN}$ & NO32 & $\mathrm{NO} 2$ & TAON & NH4 & $\mathrm{B}$ & PB & BACT & $\begin{array}{l}\text { No. of constituents } \\
\text { with seasonal } \\
\text { dependency }\end{array}$ \\
\hline Hackensack & 01377000 & - & - & - & $S$ & - & $S$ & $S$ & $S$ & $S$ & $S$ & $S$ & $S$ & $S$ & - & - & - & - & $S$ & 10 \\
\hline \multirow[t]{2}{*}{ Upper Passaic } & 01379000 & $S$ & - & $S$ & $S$ & - & $S$ & $S$ & $S$ & $S$ & $S$ & - & $S$ & $S$ & - & - & - & - & $S$ & 11 \\
\hline & 01379500 & S & $\mathrm{S}$ & $\mathrm{S}$ & - & - & $S$ & S & S & S & S & - & S & S & - & - & - & - & $S$ & 11 \\
\hline \multirow[t]{2}{*}{ Rockaway } & 01380500 & $S$ & - & $S$ & - & - & - & - & $S$ & - & - & - & - & - & - & - & - & - & - & 3 \\
\hline & 01381200 & - & - & $S$ & - & - & $\mathrm{S}$ & $S$ & $S$ & S & - & - & - & $S$ & - & - & - & - & $\mathrm{S}$ & 7 \\
\hline \multirow[t]{2}{*}{ Whippany } & 01381500 & - & - & - & $\mathrm{S}$ & $S$ & $S$ & $S$ & $S$ & - & - & - & - & $S$ & - & - & - & - & - & 6 \\
\hline & 01381800 & - & $S$ & S & $S$ & $S$ & S & S & S & S & - & - & - & S & - & - & - & - & - & 9 \\
\hline Upper Passaic & 01382000 & $S$ & $S$ & $S$ & - & $S$ & $S$ & $S$ & $S$ & $S$ & $S$ & - & - & $S$ & - & - & - & - & $S$ & 11 \\
\hline Pequannock & 01382500 & - & - & $S$ & - & - & - & - & $S$ & - & - & - & $S$ & - & - & - & - & - & $\mathrm{S}$ & 4 \\
\hline \multirow[t]{2}{*}{ Ramapo } & 01387500 & - & - & - & - & - & S & $S$ & $S$ & $S$ & - & $S$ & - & - & - & - & - & - & $\mathrm{S}$ & 6 \\
\hline & 01388000 & S & - & $S$ & - & $\mathrm{S}$ & $S$ & S & $S$ & - & - & - & $\mathrm{S}$ & - & $\mathrm{S}$ & - & - & - & - & 8 \\
\hline Pompton & 01388600 & - & - & $S$ & - & $S$ & $S$ & $S$ & $S$ & $S$ & $S$ & - & $S$ & $S$ & $S$ & - & - & - & - & 10 \\
\hline \multirow[t]{3}{*}{ Lower Passaic } & 01389005 & - & - & $S$ & - & $\mathrm{S}$ & $S$ & $S$ & $S$ & $S$ & $S$ & - & - & $S$ & - & - & - & - & - & 8 \\
\hline & 01389500 & - & $S$ & S & $S$ & $S$ & $S$ & S & S & - & $S$ & S & S & S & $S$ & $S$ & - & - & - & 13 \\
\hline & 01389880 & - & - & - & $S$ & $S$ & $S$ & - & $S$ & - & $S$ & $S$ & - & - & $S$ & $S$ & - & - & - & 8 \\
\hline Saddle & 01391500 & - & $\mathrm{S}$ & $S$ & - & $S$ & $S$ & $S$ & $S$ & $S$ & - & - & - & $S$ & $S$ & $S$ & - & - & $S$ & 11 \\
\hline Elizabeth & 01393450 & - & $S$ & - & - & $S$ & $S$ & $S$ & $S$ & - & - & $S$ & $S$ & - & - & - & - & - & $\mathrm{S}$ & 8 \\
\hline \multirow[t]{2}{*}{ Rahway } & 01394500 & - & - & $S$ & $S$ & $S$ & $S$ & $S$ & $S$ & $S$ & $S$ & - & $S$ & $S$ & $S$ & $S$ & - & - & $S$ & 13 \\
\hline & 01395000 & - & $\mathrm{S}$ & $S$ & - & $\mathrm{S}$ & $S$ & $S$ & $S$ & $S$ & $S$ & - & $S$ & $\mathrm{~S}$ & $\mathrm{~S}$ & - & - & - & $\mathrm{S}$ & 12 \\
\hline \multicolumn{2}{|c|}{$\begin{array}{l}\text { No. of stations with seasonal } \\
\text { dependency }\end{array}$} & 5 & 7 & 14 & 7 & 12 & 17 & 16 & 19 & 12 & 10 & 5 & 10 & 13 & 7 & 4 & 0 & 0 & 11 & -- \\
\hline
\end{tabular}


Table 27. Maximum, minimum, and spread of load-to-streamflow slopes for selected constituents at surface-water-quality stations in the Hackensack, Passaic, Elizabeth, and Rahway River Basins, N.J., water years 1976-93

[USGS, U.S. Geological Survey; ALK, alkalinity; HARD, hardness; TOC, total organic carbon; SS, suspended sediment; DS, dissolved solids; NA, sodium; CL, chloride; H, high-slope category; L, low-slope category; -, moderate-slope category; --, no total]

\begin{tabular}{|c|c|c|c|c|c|c|c|c|c|c|}
\hline River basin & $\begin{array}{l}\text { USGS station } \\
\text { number }\end{array}$ & ALK & HARD & TOC & SS & DS & NA & $\mathrm{CL}$ & $\begin{array}{c}\text { Number of } \\
\text { constituents with } \\
\text { high slopes }\end{array}$ & $\begin{array}{c}\text { Number of } \\
\text { constituents with } \\
\text { low slopes }\end{array}$ \\
\hline Hackensack & 01377000 & $\mathrm{H}$ & $\mathrm{H}$ & - & - & $\mathrm{H}$ & $\mathrm{H}$ & - & 4 & 0 \\
\hline \multirow[t]{2}{*}{ Upper Passaic } & 01379000 & - & - & - & $\mathrm{L}$ & - & - & - & 0 & 1 \\
\hline & 01379500 & - & - & - & - & $\mathrm{L}$ & $\mathrm{L}$ & $\mathrm{L}$ & 0 & 3 \\
\hline \multirow[t]{2}{*}{ Rockaway } & 01380500 & $\mathrm{~L}$ & - & - & - & - & - & - & 0 & 1 \\
\hline & 01381200 & $\mathrm{~L}$ & - & - & - & - & - & - & 0 & 1 \\
\hline \multirow[t]{2}{*}{ Whippany } & 01381500 & $\mathrm{~L}$ & - & - & $\mathrm{H}$ & - & - & - & 1 & 1 \\
\hline & 01381800 & $\mathrm{~L}$ & $\mathrm{~L}$ & - & - & $\mathrm{L}$ & - & - & 0 & 3 \\
\hline Upper Passaic & 01382000 & $\mathrm{~L}$ & - & - & $\mathrm{L}$ & $\mathrm{L}$ & $\mathrm{L}$ & $\mathrm{L}$ & 0 & 5 \\
\hline Pequannock & 01382500 & $\mathrm{H}$ & $\mathrm{H}$ & - & - & - & - & - & 2 & 0 \\
\hline \multirow[t]{2}{*}{ Ramapo } & 01387500 & - & - & $\mathrm{L}$ & - & - & - & - & 0 & 1 \\
\hline & 01388000 & - & - & $\mathrm{L}$ & - & - & - & - & 0 & 1 \\
\hline Pompton & 01388600 & - & - & $\mathrm{L}$ & - & - & - & - & 0 & 1 \\
\hline \multirow[t]{3}{*}{ Lower Passaic } & 01389005 & - & - & - & - & $\mathrm{L}$ & $\mathrm{L}$ & $\mathrm{L}$ & 0 & 3 \\
\hline & 01389500 & - & - & - & - & - & - & - & 0 & 0 \\
\hline & 01389880 & - & - & - & - & - & - & - & 0 & 0 \\
\hline Saddle & 01391500 & $\mathrm{H}$ & - & - & $\mathrm{L}$ & - & $\mathrm{L}$ & - & 1 & 2 \\
\hline Elizabeth & 01393450 & $\mathrm{~L}$ & $\mathrm{~L}$ & $\mathrm{H}$ & $\mathrm{H}$ & $\mathrm{L}$ & $\mathrm{L}$ & $\mathrm{L}$ & 2 & 5 \\
\hline \multirow[t]{2}{*}{ Rahway } & 01394500 & - & - & - & - & $\mathrm{H}$ & $\mathrm{H}$ & $\mathrm{H}$ & 3 & 0 \\
\hline & 01395000 & $\mathrm{H}$ & $\mathrm{H}$ & - & - & $\mathrm{H}$ & $\mathrm{H}$ & $\mathrm{H}$ & 5 & 0 \\
\hline \multicolumn{2}{|c|}{ Number of stations with high slopes } & 4 & 3 & 1 & 2 & 3 & 3 & 2 & -- & -- \\
\hline \multicolumn{2}{|c|}{ Number of stations with low slopes } & 6 & 2 & 3 & 3 & 5 & 5 & 4 & -- & -- \\
\hline \multicolumn{2}{|l|}{ Maximum slope } & .92 & .93 & 1.22 & 1.92 & .99 & 1.11 & 1.09 & -- & -- \\
\hline \multicolumn{2}{|l|}{ Minimum slope } & .62 & .56 & .81 & .85 & .62 & .57 & .58 & -- & -- \\
\hline \multicolumn{2}{|c|}{ Spread between maximum and minimum slopes } & .30 & .37 & .41 & 1.07 & .37 & .53 & .51 & -- & -- \\
\hline
\end{tabular}




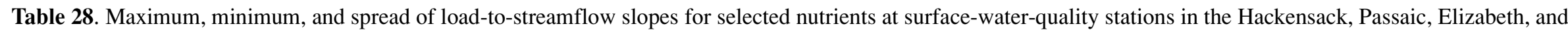
Rahway River Basins, N.J., water years 1976-93

[USGS, U.S. Geological Survey; TP, total phosphorus; TN, total nitrogen; NO32, nitrate plus nitrite; NO2, nitrite; TAON, total ammonia plus organic nitrogen; NH4, ammonia; H, high-slope category; L, low-slope category; -, moderate-slope category; --no total]

\begin{tabular}{|c|c|c|c|c|c|c|c|c|c|}
\hline River basin & $\begin{array}{c}\text { USGS station } \\
\text { number }\end{array}$ & $\mathrm{TP}$ & $\mathrm{TN}$ & NO32 & $\mathrm{NO} 2$ & TAON & $\mathrm{NH} 4$ & $\begin{array}{l}\text { Number of } \\
\text { constituents with } \\
\text { high slopes }\end{array}$ & $\begin{array}{c}\text { Number of } \\
\text { constituents with } \\
\text { low slopes }\end{array}$ \\
\hline Hackensack & 01377000 & $\mathrm{H}$ & - & - & $\mathrm{H}$ & $\mathrm{H}$ & - & 3 & 0 \\
\hline \multirow[t]{2}{*}{ Upper Passaic } & 01379000 & - & $\mathrm{H}$ & $\mathrm{H}$ & $\mathrm{H}$ & - & - & 3 & 0 \\
\hline & 01379500 & - & - & - & - & - & - & 0 & 0 \\
\hline \multirow[t]{2}{*}{ Rockaway } & 01380500 & $\mathrm{H}$ & $\mathrm{H}$ & $\mathrm{H}$ & $\mathrm{H}$ & $\mathrm{H}$ & $\mathrm{H}$ & 6 & 0 \\
\hline & 01381200 & $\mathrm{~L}$ & $\mathrm{~L}$ & $\mathrm{~L}$ & - & $\mathrm{L}$ & - & 0 & 4 \\
\hline \multirow[t]{2}{*}{ Whippany } & 01381500 & - & - & - & - & - & $\mathrm{H}$ & 1 & 0 \\
\hline & 01381800 & $\mathrm{~L}$ & $\mathrm{~L}$ & $\mathrm{~L}$ & $\mathrm{~L}$ & $\mathrm{~L}$ & $\mathrm{~L}$ & 0 & 6 \\
\hline Upper Passaic & 01382000 & $\mathrm{~L}$ & $\mathrm{~L}$ & $\mathrm{~L}$ & - & $\mathrm{L}$ & $\mathrm{L}$ & 0 & 5 \\
\hline Pequannock & 01382500 & - & $\mathrm{H}$ & $\mathrm{H}$ & $\mathrm{H}$ & - & - & 3 & 0 \\
\hline \multirow{2}{*}{ Ramapo } & 01387500 & - & - & - & - & $\mathrm{L}$ & - & 0 & 1 \\
\hline & 01388000 & $\mathrm{H}$ & $\mathrm{H}$ & $\mathrm{H}$ & $\mathrm{H}$ & - & $\mathrm{H}$ & 5 & 0 \\
\hline Pompton & 01388600 & - & - & - & - & - & - & 0 & 0 \\
\hline \multirow[t]{3}{*}{ Lower Passaic } & 01389005 & $\mathrm{~L}$ & $\mathrm{~L}$ & $\mathrm{~L}$ & - & - & - & 0 & 3 \\
\hline & 01389500 & - & $\mathrm{L}$ & $\mathrm{L}$ & - & - & - & 0 & 2 \\
\hline & 01389880 & - & - & - & - & - & $\mathrm{H}$ & 1 & 0 \\
\hline Saddle & 01391500 & $\mathrm{~L}$ & - & - & $\mathrm{L}$ & $\mathrm{L}$ & $\mathrm{L}$ & 0 & 4 \\
\hline Elizabeth & 01393450 & $\mathrm{H}$ & $\mathrm{H}$ & - & $\mathrm{H}$ & $\mathrm{H}$ & $\mathrm{H}$ & 5 & 0 \\
\hline \multirow[t]{2}{*}{ Rahway } & 01394500 & - & $\mathrm{H}$ & - & $\mathrm{H}$ & $\mathrm{H}$ & - & 3 & 0 \\
\hline & 01395000 & $\mathrm{H}$ & $\mathrm{H}$ & $\mathrm{H}$ & $\mathrm{H}$ & $\mathrm{H}$ & $\mathrm{H}$ & 6 & 0 \\
\hline \multicolumn{2}{|c|}{ Number of stations with high slopes } & 5 & 7 & 5 & 8 & 5 & 6 & -- & -- \\
\hline \multicolumn{2}{|c|}{ Number of stations with low slopes } & 5 & 5 & 5 & 2 & 5 & 3 & -- & -- \\
\hline \multicolumn{2}{|l|}{ Maximum slope } & 1.17 & 1.11 & 1.24 & 1.09 & 1.12 & 1.20 & -- & -- \\
\hline \multicolumn{2}{|c|}{ Minimum slope } & .28 & .40 & .34 & .00 & .55 & .25 & -- & -- \\
\hline \multicolumn{2}{|c|}{ Spread of maximum and minimum slopes } & .89 & .71 & .90 & 1.09 & .57 & .96 & -- & -- \\
\hline
\end{tabular}


Rivers, most slopes for nutrients are in the high range. A significant number of low-range slopes and no high range slopes are evident for 3812 on the Rockaway River, 3818 on the Whippany River, 3820 on the Passaic River, and 3915 on the Saddle River, suggesting an increased relative importance of point sources and ground water.

\section{SUMMARY}

The U.S. Geological Survey, in cooperation with the New Jersey Department of Environmental Protection, investigated the quality of surface water in the Hackensack, Passaic, Elizabeth, and Rahway River Basins during water years 1976-93. After selection of the appropriate surface-water-quality stations, constituents, and period of record, the water-quality data, instantaneous streamflow data, and flow durations were compiled and checked for accuracy. A project data base was maintained, and statistical parameters, such as median constituent concentrations, slopes of regression for load to streamflow and concentration to streamflow, and trends in constituent concentrations over time, were determined. Eighteen water-quality constituents at 19 surface-water-quality stations were investigated. The relative contributions of constant and intermittent sources of water-quality constituents were evaluated by testing for trends in concentrations during low and high flows, and qualitative values of source contributions were estimated by statistically defining the relations between concentration and streamflow, and load and streamflow.

Results of trend analysis can indicate the relative contributions of constant and intermittent sources to stream-water quality over time within a basin. A trend in concentrations during high-flow conditions can indicate increasing or decreasing intermittent source contributions over time, and a trend in concentrations during low-flow conditions can indicate increasing or decreasing constant source contributions over time.

The relations of load to streamflow also were studied. The slopes of regression lines of load to streamflow were grouped into low ( $\leq 25$ percent), medium $(>25$ percent to $<75$ percent), and high ( $\geq 75$ percent) ranges in order to compare sites by constituent. At sites with slopes in the high range, contributions to instream loads from storm runoff probably are larger than at other sites in the study area, indicating an increased relative importance of intermittent (nonpoint storm runoff) source contributions. At sites with slopes in the low range, contributions to instream loads from intermittent sources probably are smaller than at other sites in the study area, indicating an increased relative importance of constant (point sources and ground water) source contributions. For constituents with large slopes of load to streamflow (for example, total organic carbon, suspended sediment, and lead), storm runoff is most likely the significant contributor to instream loads, even for stations with load slopes in the low range. Constituent concentrations cannot be related to streamflow in the same way as load because contributions from storm runoff are flow dependent.

Trends during low-flows are positive (increasing constant-rate source contributions) at one station for hardness, total nitrate plus nitrite, and fecal coliform; at two stations for dissolved oxygen and fraction of dissolved oxygen at saturation; and at three stations for dissolved chloride. Trends during low flows are negative (decreasing constant-rate source contributions) at three stations for total ammonia plus organic nitrogen and at two stations for total ammonia. 
Trends during high flows are positive (increasing intermittent source contributions) at one station for dissolved solids and dissolved oxygen; at two stations for hardness, dissolved sodium, and fraction of dissolved oxygen at saturation; and at three stations for dissolved chloride. Trends during high flows are negative (decreasing intermittent source contributions) at one station for total organic carbon, suspended solids, total ammonia, and fecal coliform bacteria, and at three stations for total ammonia plus organic nitrogen.

Insufficient data are available to determine trends in concentrations for high- and low-flow conditions at 8 of the 19 water-quality stations, indicating a need for additional data collection or a change in the data-collection schedule.

The relations of concentration to streamflow indicate seasonal dependency at one or more stations for 16 of the 18 constituents. Seasonal dependency is not indicated for total boron and lead. Slopes for alkalinity and hardness are negative at all stations. Slopes for dissolved solids, dissolved sodium, dissolved chloride, total phosphorus, total nitrogen, total nitrate plus nitrite, and total boron are negative at most stations. Slopes for total nitrate, total ammonia plus organic nitrogen, and total ammonia are almost equally divided between negative slopes and zero slopes (zero indicates the slope is not different from zero at the 0.05 significance level). Slopes for total organic carbon are negative at three stations and positive at three stations; all other stations have zero slopes. Slopes for suspended sediment are positive at five stations and zero at all other stations. Slopes for dissolved oxygen and fraction of dissolved oxygen at saturation are positive at most stations. Slopes for total lead and fecal coliform bacteria are almost equally divided between positive and zero slopes.

For most constituents, load-to-streamflow relations at stations along a river reach remain constant or decrease in a downstream direction, indicating smaller contributions from intermittent sources than from constant-rate sources. The slopes increase in the downstream direction for some or all of the nutrient species at the Ramapo, lower Passaic, and Rahway Rivers; for dissolved solids, dissolved sodium, and dissolved chloride at the lower Passaic River; and for alkalinity and hardness at the Rahway River.

The relation of load to streamflow provides a qualitative estimate of the relative contributions of nonpoint storm runoff and ground water, and point sources, to surface-water quality and represents preliminary results of the total maximum daily load process for the State's watersheds. The results of this study, along with identification of constant-rate sources, additional water-quality data collected during low- and high-flows, and ground-water data (water-quality data, water levels, flow rates, and travel times) could facilitate a more detailed analysis of the overall hydrology of these river basins. 


\section{REFERENCES CITED}

Anderson, P.W., and Faust, S.D., 1973, Characteristics of water quality and streamflow, Passaic River basin above Little Falls, New Jersey: U.S. Geological Survey Water-Supply Paper 2026, 80 p.

1974, Water quality and streamflow characteristics, Raritan River basin, New Jersey:

U.S. Geological Survey Water-Resources Investigations Report 14-74, 82 p.

Anderson, P.W., and George, J.R., 1966, Water-quality characteristics of New Jersey streams: U.S. Geological Survey Water-Supply Paper 1819-G, 48 p.

Anderson, P.W., and Murphy, J.J., 1970, Report on the quality of water from the Hackensack River pilot desalination plant at Jersey City, New Jersey: U.S. Geological Survey Open-File Report, 16 p.

Bartlett, R.A., 1984, Rolling rivers, an encyclopedia of American rivers: New York, McGrawHill Book Company, 398 p.

Bauersfeld, W.R., Moshinsky, E.W., and Gurney, C.E., 1994, Water resources data for New Jersey - water year 1993, volume 1, surface-water data: U.S. Geological Survey WaterData Report NJ-93-1, 503 p.

Breidt, F.J., Boes, D.C., Wagner, J.I., and Flora, M.D., 1991, Antidegradation water quality criteria for the Delaware River: A distribution-free statistical approach: Water Resources Bulletin, v. 27, no. 5, p. 849-858.

Canace, Robert, Hutchinson, W.R., Saunders, W.R., and Anders, K.G., 1983, Results of the 1980-81 drought emergency ground-water investigation in Morris and Passaic Counties, New Jersey: New Jersey Geological Survey Open-File Report 83-3, 132 p.

Carswell, L.D., 1976, Appraisal of water resources in the Hackensack River basin, New Jersey: U.S. Geological Survey Water-Resources Investigations Report 76-74, 68 p.

Chow, V.T., 1964, Handbook of applied hydrology: New York, McGraw Hill, Inc., 1418 p.

Cohn, T.A., 1988, Adjusted maximum estimation of the moments of lognormal populations from type 1 censored samples: U.S. Geological Survey Open-File Report 88-350, 34 p.

Eaton, A.D., Clesceri, L.S., and Greenberg, A.E., 1995, Standard methods for the examination of water and wastewater (19th ed.): Washington, D.C., American Public Health Association, $948 \mathrm{p}$.

Fishman, M.J., and Friedman, L.C., eds., 1989, Methods for determination of inorganic substances in water and fluvial sediments: U.S. Geological Survey Techniques of WaterResources Investigations, book 5, chap. A1, 545 p. 


\section{REFERENCES CITED--Continued}

Fishman, M.J., Raese, J.W., Gerlitz, C.N., and Husband, R.A., 1994, U.S. Geological Survey approved inorganic and organic methods for the analysis of water and fluvial sediments, 1954-94: U.S. Geological Survey Open-File Report 94-351, 55 p.

Friedman, L.C., and Fishman, M.J., 1989, Evaluation of methods used from 1965 through 1982 to determine inorganic constituents in water samples: U.S. Geological Survey Water-Supply Paper 2293, $126 \mathrm{p}$.

Fusillo, T.V., 1981, Impact of Suburban Residential Development on Water Resources in the Area of Winslow Township, Camden County, New Jersey: U.S. Geological Survey WaterResources Investigations Report 81-27, 38 p.

Geonics, Ltd., 1979, Water resources study of the Rockaway Valley, Morris County, New Jersey: Clinton, N.J., Geonics, Ltd., 58 p.

Gillespie, B.D., and Schopp, R.D., 1982, Low-flow characteristics and flow duration of New Jersey streams: U.S. Geological Survey Open-File Report 81-1110, 164 p.

Hay, L.E., and Campbell, J.P., 1990, Water-quality trends in New Jersey streams: U.S. Geological Survey Water-Resources Investigations Report 90-4046, 297 p.

Helsel, D.R., and Cohn, T.A., 1988, Estimation of descriptive statistics for multiply censored water quality data: Water Resources Research, v. 24, no. 12, p. 1997-2004.

Helsel, D.R., and Hirsch, R.M., 1992, Statistical methods in water resources: New York, Elsevier Science Publishing Company, 522 p.

Hem, J.D., 1985, Study and interpretation of the chemical characteristics of natural water: U.S. Geological Survey Water Supply Paper 2254, 263 p.

Hirsch, R.M., 1982, A comparison of four streamflow record extension techniques: Water Resources Research, v. 18, no. 4, p. 1081-1088.

Hirsch, R.M., Slack, J.R., and Smith, R.A., 1982, Techniques of trend analysis for monthly water quality data: Water Resources Research, v. 18, p. 107-121.

Hutchison, N.E., 1975, WATSTORE: National Water Data Storage and Retrieval System: user's guide: U.S. Geological Survey Open-File Report 75-426, 791 p.

New Jersey Department of Environmental Protection and Energy, 1993, New Jersey 1992 State Water Quality Inventory Report: New Jersey Department of Environmental Protection and Energy, Office of Land and Water Planning, 472 p. 


\section{REFERENCES CITED--Continued}

New Jersey Department of Environmental Protection, 1989, Nonpoint Source Assessment and Management Program: New Jersey Department of Environmental Protection, Division of Water Resources, 97 p.

1994, Ambient Monitoring Network: Arthur Kill, Passaic, Hackensack, and Wallkill River Drainage Basins, 1993 Benthic Macroinvertebrate Data: Executive Summary, 22 p.

Novotny, Vladimir, and Chesters, Gordon, 1981, Handbook of nonpoint pollution sources and management: New York, Van Nostrand Reinhold Company, 555 p.

Price, C.V., and Schaefer, F.L., 1995, Estimated loads of selected constituents from permitted and nonpermitted sources at selected surface-water-quality stations in the Musconetcong, Rockaway, and Whippany River Basins, New Jersey, 1985-90: U.S. Geological Survey Water Resources Investigations Report 95-4040, 28 p.

Rand, G.M., and S.R. Petrocelli, 1985, Fundamentals of Aquatic Toxicity: Methods and Applications: Washington, D.C., Hemisphere Publishing Corporation, 666 p.

Reed, T.J., and Hunchak-Kariouk, Kathryn, 1995, Surface-water temperature statistics for streams in New Jersey and vicinity, 1955-93: U.S. Geological Survey Open-File Report 95-196, $142 \mathrm{p}$.

Robinson, K.W., and Pak, Connie, 1993, New Jersey stream water quality: U.S. Geological Survey Water-Supply Paper 2400, p. 395-402.

Rosensteel, B.A., and Strom, P.F., 1991, River Phosphorus dynamics and Reservoir Eutrophication Potential: Water Resources Bulletin 27:6, p. 957-965.

Ruffner, J.A., and Bair, F.E., eds., 1977, The weather almanac (2d ed.): New York, Avon Books, $35 \mathrm{p}$.

SAS Institute Inc., 1990, SAS/GRAPH software reference, version 6 (1st ed.): Cary, N.C., SAS Institute Inc., v. 1, 794 p.

Sawyer, C.N., and McCarty, P.L., 1978, Chemistry for environmental engineering: New York, McGraw-Hill, Inc., 532 p.

Schaefer, F.L., Harte, P.T., Smith, J.A., and Kurtz, B.A., 1993, Hydrologic conditions in the upper Rockaway River basin, New Jersey, 1984-86: U.S. Geological Survey Water-Resources Investigations Report 91-4169, 102 p.

Schornick, J.C., Jr., and Fishel, D.K., 1980, Effects of storm runoff on water quality in the Mill Creek drainage basin, Willingboro, New Jersey: U.S. Geological Survey Water-Resources Investigations Report 80-98, 111 p. 


\section{REFERENCES CITED--Continued}

Skougstad, M.W., Fishman, M.J., Friedman, L.C., Erdmann, D.E., and Duncan, S.S., 1979, Methods for determination of inorganic substances in water and fluvial sediments: U.S. Geological Survey Techniques of Water-Resources Investigations, book 5, chap. A1, $626 \mathrm{p}$.

Vecchioli, John, and Miller, E.G., 1974, Water resources of the New Jersey part of the Ramapo River basin: U.S. Geological Survey Water-Supply Paper 1974, 77 p.

Wershaw, R.L., Fishman, M.J., Grabbe, R.R., and Lowe, L.E., 1987, Methods for the determination of organic substances in water and fluvial sediments: U.S. Geological Survey Techniques of Water-Resources Investigations, book 5, chap. A3, 80 p. 